\title{
Loosening the Marriage Bond: \\ Divorce in New Zealand, c.1890s - c.1950s
}

by

Hayley Marina Brown

A thesis

submitted to the Victoria University of Wellington

in fulfilment of the requirements for the degree of

Doctor of Philosophy

in History

Victoria University of Wellington

2011 


\section{Abstract}

Based on a detailed examination of 2,195 divorce case files generated by applications to the Wellington Supreme Court, the study explores the changing frequency and character of the divorcing population in New Zealand between 1898, when the grounds for divorce were extended under the Divorce Act, until c.1959. The end point is set by access limits to divorce case files, the beginning of Marriage Guidance, and the establishment of a 'normal' pattern of divorce following the postwar spike.

The study examines how and why New Zealanders divorced in increasing numbers over the period. In particular, it looks at the increase in divorce during and after the two world wars. The rate peaked in the immediate postwar years and remaining at levels about those pre-1914 and pre-1939. The study also looks at how war contributed to an underlying and on going change in attitudes towards marriage and divorce, not solely attributable to the immediate crisis of enlistment.

The study explores the social and cultural factors influencing the decision to divorce including gender, class, religion, and the desire for, or presence of, children. Among other factors, it inquires into the reason why those who divorced in New Zealand were primarily working class, in contrast to their English counterparts, reflecting different class-based perceptions of morality and respectability. It will explore the growing emphasis on sexual pleasure and on women's attainment of social and sexual rights as contributing to the increase in divorce.

The public nature of divorce proceedings through this period, with cases being heard in open court and few limits on newspaper reporting, operated as a means of social control and public surveillance. The discussion focuses on how the courts contributed to the construction of definitions of normative behaviour of husbands and wives, judged individuals' abilities to be suitable mothers and fathers and awarded custody of children. The court also adjudicated issues of acceptable and illicit sexual behaviour with gender expectations as part of the considerations. Although those who flouted expected marital norms could risk ostracism or public condemnation, the thesis also shows that this power diminished as divorce became more common.

The thesis concludes with an examination of marriage guidance as a public recognition both of the potential for divorce and of the belief that marriages took effort to maintain and that advice and guidance support could help 'unstable' marriages regain stability. In the post-World War II period there was also an acknowledgement that some marriages could not be 'saved' with divorce being the only alternative. Regardless, of such interventions, the changes in attitudes about divorce, made divorce an increasingly acceptable solution to unhappy marriages. Divorce, as this thesis will argue, did not 'break' the marriage bonds but rather, loosened them. 


\section{Acknowledgements}

While writing a thesis can be a somewhat isolating and at times never-ending experience, it is also a task that is impossible to complete without the support of many generous and encouraging people. Firstly, I am forever grateful to my supervisors, Charlotte Macdonald, Dolores Janiewski and Malcolm McKinnon, for their continual and unwavering faith in me and for all their comments and advice over the last four years. I feel very lucky to have worked with three such wonderful academics and mentors who have made my thesis writing experience a rich and rewarding one.

I should also like to thank Steve Behrendt and Evan Roberts for their advice and assistance with using statistics and statistical software. Jim McAloon provided guidance with the difficult task of occupation classification. Peter Carter assisted with the construction of the database. Cathy Colborne, Paul Diamond, Lisa Featherstone, Jeremy Finn, Rebecca Jennings, John E. Martin and Redmer Yska have been generous with their time and advice.

I have spent countless hours in the reading room at Archives New Zealand Wellington, and would like to thank all the staff who made the research process easier. In particular, I would like to acknowledge the assistance provided by Vernon Wybrow, Graham Langton and Heidi Kuglin. I am also grateful for the help I have received at the Alexander Turnbull Library and the National Library.

Writing a thesis is an expensive undertaking, and I would not have been able to complete this work without the financial support provided by a Victoria University of Wellington PhD Scholarship and Submission Scholarship, a Claude McCarthy Fellowship 2008, an Education New Zealand Postgraduate Study Abroad Award 2008, the Wellington Historical and Early Settlers' Association James E. Worsfold Scholarship 2009, a number of grants from the Faculty of Humanities and Social Sciences Research Committee (VUW), and funding from the History Programme (VUW). A Building Research Capability in the Social Sciences (BRCSS II) Doctoral Completion Award has made the final few months of this project much easier.

Overseas, I completed research at the National Archives UK, The Women's Library at the London Metropolitan University, Library and Archives Canada in Ottawa and the British Columbia Archives, and I would like to thank the staff at these institutions for their assistance. Travelling and carrying out research overseas is not cheap, and I am very grateful to Anna Wallace and Russ Humphrey for providing me with accommodation for two weeks while I was in London, and to Eleanor Belshaw-Hauff with whom I stayed for a week in Ottawa. I hope I was a tidy house guest!

I have been very fortunate to have a strong support network of family and friends to whom I am very grateful. My mother, Dawn Brown, and her partner Rodney Venning and my father, William Brown, have been very supportive along with many good friends and fellow thesis writers. In particular I would like to acknowledge Angela Wanhalla, Daniel Farrell, Masayuki Shintani, Megan Simpson, Jamie Sedgwick, Christopher Burke, Lachy Paterson, Rebecca Lenihan, Tanja Bueltmann, Gerard Horn, Lisa Sacksen, James Taylor, Nic Dempster, Erin Keenan, Vivian Rodriguez, Nick Radburn and Michael Devine. 


\section{Table of Contents}

$\begin{array}{lll}\text { Abstract } & \text { ii }\end{array}$

Acknowledgements

Abbreviations vi

Figures, Tables and Illustrations vii

Introduction $\quad 1$

$\begin{array}{ll}\text { Chapter One: The Evolution of the Divorce Law } & 19\end{array}$

Chapter Two: Major Trends in Divorce and Divorcing Couples 53

$\begin{array}{ll}\text { Chapter Three: Divorce in the Time of War } & 73\end{array}$

$\begin{array}{ll}\text { Chapter Four: Class and the Economics of Divorce } & 102\end{array}$

Chapter Five: Privacy, Prurience and Publicity: Suspicions and 126

Surveillance in the Divorce Proceedings

Chapter Six: Expectations and Disappointments of Marriage: Succeeding 152 and Failing at being Husbands and Wives

Chapter Seven: For the Sake of the Children: Children's Part in Divorce $\quad 180$

Proceedings

Chapter Eight: The Changing Landscape of Marriage and Sexuality 195

$\begin{array}{ll}\text { Epilogue and Conclusion } & 213\end{array}$

$\begin{array}{ll}\text { Appendices } & 234\end{array}$

$\begin{array}{ll}\text { Bibliography } & 257\end{array}$ 


\section{Abbreviations}

$\begin{array}{ll}\text { AFS } & \text { Australian Feminist Studies } \\ \text { AHS } & \text { Australian Historical Studies } \\ \text { ANZ-A } & \text { Archives New Zealand, Auckland } \\ \text { ANZ-C } & \text { Archives New Zealand, Christchurch } \\ \text { ANZ-W } & \text { Archives New Zealand, Wellington } \\ \text { ATL } & \text { Alexander Turnbull Library } \\ \text { DNZB } & \text { Dictionary of New Zealand Biography } \\ \text { EP } & \text { Evening Post } \\ \text { FS } & \text { Feminist Studies } \\ \text { GLR } & \text { Gazette Law Reports, New Zealand } \\ \text { G\&H } & \text { Gender \& History } \\ H F & \text { The History of the Family } \\ H W J & \text { History Workshop Journal } \\ J F H & \text { Journal of Family History } \\ \text { JHS } & \text { Journal of the History of Sexuality } \\ J S H & \text { Journal of Social History } \\ J W H & \text { Journal of Women's History } \\ \text { LHR } & \text { Law and History Review } \\ \text { MHR } & \text { Member of the House of Representatives } \\ \text { MLC } & \text { Member of the Legislative Council } \\ \text { NA(UK) } & \text { National Archives, United Kingdom } \\ \text { NCC } & \text { National Council of Churches } \\ \text { NZG } & \text { New Zealand Gazette } \\ \text { NZJH } & \text { New Zealand Journal of History } \\ \text { NZLR } & \text { New Zealand Law Reports } \\ \text { NZPD } & \text { New Zealand Parliamentary Debates } \\ \text { NZT } & \text { New Zealand Truth } \\ \text { NZWW } & \text { New Zealand Women's Weekly } \\ P S & \text { Population Studies } \\ \text { VS } & \text { Victorian Studies } \\ \text { SPWC } & \text { Society for the Protection of Women and Children } \\ \text { WHR } & \text { Women's History Review } \\ \text { WL } & \text { Women's Library, London Metropolitan University } \\ \text { WR } & \text { White Ribbon } \\ & \end{array}$




\section{Figures, Tables and Illustrations}

\section{Figures:}

2.1 Petitions and Decrees Absolute for Divorce, 1898-1959 53

2.2 New Zealand Divorce Rate, per 1,000 married couples, 1898-1959 54

2.3 Divorce Petitions by Husbands and Wives, 1915-1959 55

2.4 Grounds for Divorce - Wife Petitioner, 1915-1959 60

2.5 Grounds for Divorce - Husband Petitioner, 1915-1959 61

2.6 Divorce Petitions on the Ground of Separation of 3+ Years, 1921-1947 63

2.7 Wellington Petitions for Divorce as a Proportion of Total Petitions for 64 Divorce in New Zealand, 1898-1952

2.8 Number of Divorce Petitions Filed for the Four Major Courts, 1898-1952 65

2.9 The Crude Divorce Rates (number of divorces per 1,000 total population) 66 1910-1950

2.10 Location of Wedding Ceremony by Divorce Petition Year, 1898-1947 69

3.1 Length of Marriage at Time of Decree Absolute, 1915-1921 79

3.2 Length of Marriage at Time of Decree Absolute, 1939-1949 80

6.1 Petitions on the Ground of Drunkenness, Cruelty etc. by Petitioner, 1915- 168 1959

6.2 Petitions on the Ground of Insanity by Petitioner, 1915-1959 175

8.1 Adultery Petitions as a Percentage of All Divorce Petitions, 1915-1959 198

8.2 Petitions for Divorce on the Ground of Adultery by Petitioner, 1915-1959 199

\section{Tables:}

1.1 Introduction of First Divorce Legislation in England, Wales and Australasia 23

1.2 Removal of the Sexual Double Standard from Divorce Legislation in 30 England, Wales and Australasia

1.3 Introduction of Desertion as a Ground for Divorce as a Ground for Divorce 31 in England, Wales and Australasia

2.1 Success Rate of Husbands and Wives Divorce Petitions, in the Wellington 56 Supreme Court, 1898-1947

2.2 Marital Status at Marriage for those who Divorce in the Wellington 57 Supreme Court, 1898-1947

2.3 Age at Marriage for those who Divorced in the Wellington Supreme Court, $\quad 57$ 1898-1947

2.4 Percentage of Divorced Persons by Gender and Religious Affiliation for the Four Main Denominations, 1926-1956

2.5 Location of Marriage by Denomination of Church, 1898-1947 70

2.6 Percentage of Marriages which were 'Shotgun' by Location of Wedding 71 Ceremony, 1898-1947

4.1 Occupations as listed on the Marriage Certificate 105

4.2 Distribution in Occupational Categories of Grooms and Brides' Fathers, 107 1898-1947 (percentages)

4.3 New Zealand's non-Maori Male urban occupational structure 1901, $1926 \quad 108$ and 1936 Compared with the Breakdown of Husbands' Occupations at the time of Divorce (excluding rural, students, military and undefined occupations) 
4.4 Awards for Costs Made in Divorce Cases, Wellington Supreme Court, 115 1898-1947

4.5 Damages Requested and Awarded by Decade

4.6 Damages Requested and Awarded in Adultery Cases, 1898-1947 117

4.7 Women's Average Annual Income by Marital Status Compared with the Average Male Income

7.1 Number of Divorce Petitions where the First Child was born within the First Seven Months of Marriage (or prior to the marriage) as a percentage of all divorce petitions $(\mathrm{N}=2166)$

7.2 Number of Children to Each Divorcing Couple, 1898-1947

7.3 Mean Number of Children per Couple by Petition Year

7.4 Mean Length of Marriage in Years by Family Size

7.5 The Awarding of Child Custody by Petitioner

\section{Illustrations:}

3.1 Cartoon showing large numbers of people entering the Divorce Court, and putting the blame for this on 'Warriors' Wives Who Went Wrong' and more indirectly on Kaiser Wilhelm 


\section{Introduction}

This thesis explores the practice of divorce in New Zealand from the reform of the law in 1898 to the 1950 s when access to the divorce case files, which form its primary evidentiary basis, terminates on the cusp of another phase of major legal and social change. Divorce was not an easy step to take as divorced people were stigmatised, although this negative view of divorce decreased over time. Some New Zealanders considered the increasing number of divorces as a social crisis turning 'divorce' into a byword for the fragility of marriage and society as a whole. For other New Zealanders the divorce law offered a chance to get out of a marriage no longer working and the opportunity to remarry. As Roderick Phillips noted in his study of divorce across the western world in the twentieth century, divorce changed 'from a last resort of the desperate few to being the most attractive and common response to marriage breakdown' offering the 'complete dissolution of marriage, a distribution of property, arrangements for the custody of children, and, perhaps most importantly, the possibility of remarriage'. ${ }^{1}$ Placing the New Zealand pattern in an international context highlights New Zealand's relatively high divorce rate and liberal divorce law in the period c.1890s to the 1950s, suggesting a greater willingness on the part of lawmakers and the public to accept divorce than in other comparable societies. Divorce, as this thesis will argue, did not 'break' the marriage bonds but rather, loosened them. Marriage remained popular but a single marriage, 'till death do us part', for life, was no longer either the only expectation or practice.

Roderick Phillips' 1981 study of divorce is the major existing account of the history of divorce in New Zealand. ${ }^{2}$ Phillips' study, on the development of New Zealand's divorce legislation from 1867, includes a small case study of divorce in nineteenth-century Auckland. Beyond Phillips' useful study, divorce forms only a small part of studies of marriage, demography, the family and gender. Yet there was continual development in the law, and throughout the twentieth century, divorce became more and more common.

\footnotetext{
${ }^{1}$ Roderick Phillips. Putting Asunder: A History of Divorce in Western Society. Cambridge: 1988, 203.

${ }^{2}$ Roderick Phillips. Divorce in New Zealand: A Social History. Auckland: 1981. More recently Margaret McClure has conducted an oral history study of women's experiences of divorce in New Zealand during the 1950s and 1960s. This work has produced one short article to date, and is based on a sample of only nine women. See Margaret McClure. “When a Happy Marriage Turns to Custard”. Women’s Stories of Divorce in the 1950s and 1960s'. Oral History in New Zealand, 18 (2006): 1-4.
} 
As far back as 1986 Raewyn Dalziel noted little was known of the experience women had of courtship and marriage in nineteenth-century New Zealand, despite it being the experience of the majority. ${ }^{3}$ There have been studies of marriage since, but not of divorce beyond brief passing mentions. ${ }^{4}$ Erik Olssen argued in 2005 that 'historical studies of marriage have been few and far between'. This study seeks to address that gap. While some attention is paid to changes in the law, the greater focus is on the practice of divorce and trends over time in terms of incidence; characteristics of the divorcing population; how the legal process operated for petitioners and other parties; and what case files reveal of the intersection of law and society.

In examining divorce in New Zealand c.1890s - 1950s, the study focuses on how the law was used rather than on campaigns for and against legal change. From 1898, when the original 1867 law was amended, to 1947 approximately 28,000 divorces were granted in New Zealand's Supreme Court. ${ }^{6}$ Why did New Zealand couples use these laws with increasing frequency from 1898 to 1947 ? This thesis will answer the question by analysing the evidence created during the legal process which began with a husband or wife petitioning to divorce. This legal process created case files containing the marriage certificate, petition, decree nisi and decree absolute, but could also include personal

\footnotetext{
${ }^{3}$ Raewyn Dalziel. “"Making Us One”: Courtship and Marriage in Colonial New Zealand'. The Turnbull Library Record 19, no.1 (1986): 7.

${ }^{4}$ The most recent historical studies of marriage, demography and the family in New Zealand include, Ian Pool, Arunachalam Dharmalingam and Janet Sceats. The New Zealand Family from 1840. A Demographic History. Auckland: 2007; David Thomson. 'Marriage and the Family on the Colonial Frontier', in Disputed Histories. Imagining New Zealand's Pasts. Dunedin: 2006, 119-41; Charlotte Macdonald. 'Too Many Men and Too Few Women: Gender's "Fatal Impact" in Nineteenth-Century Colonies', in The Gendered Kiwi, eds. Caroline Daley and Deborah Montgomerie. Auckland: 1999, 17-35; Erik Olssen. 'Families and the Gendering of European New Zealand in the Colonial Period, 1840-80', in The Gendered Kiwi, eds. Daley and Montgomerie. Auckland: 1999, 37-62; Angela Wanhalla. 'Family, Community and Gender', in The New Oxford History of New Zealand, ed. Giselle Byrnes. Melbourne: 2009, 447-64; Angela Wanhalla. In/Visible Sight: The Mixed-Descent Families of Southern New Zealand. Wellington: 2009; Erik Olssen. “"For Better or Worse": Marriage Patterns in Dunedin's Southern Suburbs, 1881-1938', in Class, Gender and the Vote. Historical Perspectives from New Zealand, eds. Miles Fairburn and Erik Olssen. Otago: 2005, 75-100; Barbara Brookes, 'Marriage: The Gendered Contract,' in Sites of Gender. Women, Men and Modernity in Southern Dunedin, 1890-1939, eds. Brookes et al. Auckland: 2003, 348-55; Megan Simpson. 'The Action for Breach of Promise of Marriage in Early Colonial New Zealand: Fitzgerald v Clifford (1846)'. Victoria University of Wellington Law Review 41, no.3 (2010): 473-91.

${ }^{5}$ Olssen. 'For Better or Worse', 75. Some historians have even inaccurately represented New Zealand's divorce laws. For example, in her general history of New Zealand, Philippa Mein Smith claims, incorrectly, that New Zealand was 'relatively late to adopt marriage reform, introducing equal rights to divorce in 1898, after Britain and the Australian colonies'. As Chapter One shows, in 1898 New Zealand was the second Australasian colony to remove the double standard from its divorce law after New South Wales, and that England and Wales did not remove the double standard until 1923. See, Philippa Mein Smith. A Concise History of New Zealand. Melbourne: 2005, 102.

${ }^{6}$ Divorce Act 1898 (62 VIC 1898 No. 42).
} 
letters and court transcripts. In making this study of divorce over a fifty year period, it is these divorce case files which provide the central evidence. A sample of 2,195 divorce files from the Wellington Supreme Court form the basis of this study of how people used the legal apparatus to end their marriages. This is reflective of Heather Brook's argument that in "law, "truth" may be inaccessible, but what remains is a record of what has counted as truth, and such records are instructive'. ${ }^{7}$ Following James Hammerton's lead, this thesis uses divorce records 'as a vehicle for illumination of patterns of marriage' in which the mundane reveals the typical patterns of marriage, instead of only noticing the 'sensational' adultery cases which occasionally attracted media attention. ${ }^{8}$ At the core of the study lie questions about the frequency of divorce, the composition of the divorcing population, changing patterns in use of the legal grounds for divorce, and the associated insights to be gained on marriage and couples' estrangement in its various dimensions in the records produced for and by the divorce process.

A study of divorce is inevitably also a study of marriage. As Lawrence Stone has argued, '[s]ince divorce is an outcome of marriage, its evolution is inextricably bound up with that of the latter'. ${ }^{9}$ Marriage, and its twentieth-century correlate divorce, was central in shaping gender identities. Barbara Brookes notes, 'work, home, and family [were] at the heart of the gender order' giving 'meaning to lives' and defining the successful from the failures. She particularly emphasises marriage as 'the place where the state most directly shaped gendered authority. Monogamy and heterosexuality were upheld, whereas bigamy and homosexuality were proscribed'. ${ }^{10}$ The status, responsibilities and identities of women and men as wives and husbands were upheld in myriad aspects of state activity. By the twentieth century, it was the state as much as than the church, which took primary responsibility for regulating marriage. The marriage relationship was a fundamental model of social order and hierarchy; relations between husband and wife were long assumed, defined and upheld, with the bride promising 'to honour and obey'. Marriage was simultaneously a public and private contract; divorce was similarly the public dissolution of that private contract. In Norma Basch's view, 'divorce derived its symbolic punch from its capacity to undermine the contract of marriage, and marriage was (and is)

\footnotetext{
${ }^{7}$ Heather Brook. Conjugal Rites. Marriage and Marriage-like Relationships before the Law. New York: 2007, 10.

${ }^{8}$ A. James Hammerton. Cruelty and Companionship. Conflict in Nineteenth-Century Married Life. London and New York: 1992, 3.

${ }^{9}$ Lawrence Stone. Road to Divorce: England 1530-1987. Oxford: 1990, 6.

${ }^{10}$ Brookes, 389.
} 
a metonym for the social order'. ${ }^{11}$ Divorce became a threat to social order and to the gender system. This thesis explores how marriage and divorce created, managed and revealed gender identities. Using a qualitative and a quantitative approach, the thesis explores changing ideas about 'good' marriages and normative standards of femininity, masculinity and sexuality. ${ }^{12}$

As Roderick Phillips has noted, grounds for divorce, and also 'complaints' contained in divorce files provide a 'mirror image' of marital expectations. They indicate the sorts of behaviour that husbands and wives considered 'crimes' against the marriage bargain. ${ }^{13}$ Taken up by conservatives, these claims turned into warnings against heightened expectations about marital satisfaction because it was believed that frustrated desires would lead to increasing numbers of divorces. Coming as they do from a fifty year period, the divorce case records reveal changing and sometimes conflicting ideas about marriage. Some historians have argued that this period saw the rise of companionate marriage. According to Janet Finch and Penny Summerfield, the phrase 'companionate marriage' included 'a set of ideas about marriage which ranged from the notion that there should be greater companionship between partners whose roles essentially were different, though, the idea of marriage as "teamwork", to the concept of marriages based on "sharing" implying the breakdown of clearly demarcated roles'. ${ }^{14}$ John Gillis has argued that 'the conjugal has always been more an illusive dream than an attainable reality' and suggested that the expectation of ultimate happiness places a severe strain on marriage leading to its unloosening. ${ }^{15}$ This analysis will also reveal the social significance attached to being married when contemplating people's expectations of marriage and trying to understand

\footnotetext{
${ }^{11}$ Norma Basch. Framing American Divorce. From the Revolutionary Generation to the Victorians. Berkeley: 1999, 3.

${ }^{12}$ Deborah Montgomerie has written about how masculinity, femininity and family are not static but 'dynamic and interlinked social formations that are constantly reinscribed and renegotiated on the shifting terrain of individual desire, social sanction and marital possibility'. See, 'Sweethearts, Soldiers, Happy Families: Gender and the Second World War', in The Gendered Kiwi, eds. Caroline Daley and Deborah Montgomerie. Auckland: 1999, 166.

${ }^{13}$ Phillips, Putting Asunder, 596.

${ }^{14}$ Janet Finch and Penny Summerfield. 'Social Reconstruction and the Emergence of Companionate Marriage, 1945-49', in Marriage, Domestic Life and Social Change. Writings for Jacqueline Burgoyne (1944 - 88), ed, David Clark. London: 1991, 7. For other discussions of companionate marriage see, John D'Emilio and Estelle Freedman. Intimate Matters: A History of Sexuality in America. New York: 1988, 265-70; Christina Simmons. Making Marriage Modern. Women's Sexuality from the Progressive Era to World War II. New York: 2009, 105-37; Simon Szreter and Kate Fisher. 'Love and Authority in MidTwentieth-Century Marriages: Sharing and Caring', in The Politics of Domestic Authority in Britain since 1800, eds. Lucy Delap et al. Houndmills: 2009, 132-54.

${ }^{15}$ John R. Gillis. For Better, For Worse: British Marriages, 1600 to the Present. New York: 1985, 5.
} 
the circumstances in which marriages came to an end. Like the anxieties about the instability of many marriages and the negative views about the unmarried that Katherine Holden discovered in post-World War I Britain, the thesis will explore the pressures that made New Zealanders marry but also influenced the decision to divorce. ${ }^{16}$

With nineteenth-century origins as a British settler colony, New Zealand was a predominantly Protestant society, with Anglicanism being the dominant denomination, although there was never a state church or a legally established religion. ${ }^{17}$ By introducing statute divorce law in 1867, 10 years after England's 1857 measure, New Zealand formed part of a pattern of British settler societies, following England's lead. Many states of the United States had much older divorce laws, as did those European states most influenced by Martin Luther and John Calvin: Protestant Germany, the Scandinavian states, Geneva and Scotland. ${ }^{18}$ On the other hand, those states which were predominantly Catholic introduced divorce laws later. France, with strongly bifurcated secular and Catholic traditions reintroduced divorce in 1884 (it had previously been legal between 1792 and 1816) while Portugal did so in 1910. Italy did not allow divorce until 1970, Spain in 1981 (although divorce had been possible between 1932 and 1939) and Ireland only in 1997. ${ }^{19}$ New Zealand formed part of a 'middle wave' of countries which introduced divorce in the mid- to late-nineteenth century, after the non-Anglican Protestant states, but usually before the principally Catholic states.

The Pakeha (non-Maori) population of New Zealand, in contrast to other British settler societies, and Britain itself, was noticeably more Scottish in terms of origin, and in contrast to Australia, far less Irish. ${ }^{20}$ James Belich has argued that the 'Scots were to New Zealand what the Irish were to Australia - the chief lieutenants of settlement'. ${ }^{21}$ One

\footnotetext{
${ }^{16}$ Katherine Holden. "Nature takes No Notice of Morality": Singleness and Married Love in Interwar Britain'. WHR 11, no.3 (2002): 485.

${ }^{17}$ John Stenhouse, 'Religion and Society', in The New Oxford History of New Zealand, ed. Giselle Byrnes. Melbourne: 2009, 340.

${ }^{18}$ Phillips, Putting Asunder, 40-71.

${ }^{19}$ Ibid., 572-81.

${ }^{20}$ Jock Phillips and Terry Hearn. Settlers. New Zealand Immigrants from England, Ireland \& Scotland. 1800-1945. Auckland: 2008, especially 51-58. By 1891 about 25 per cent of the UK-born population of New Zealand was from Scotland, whereas Scots only made up about 10 per cent of the UK population and never made up more than 15 per cent of immigrants to Australia. After an influx of Irish immigration during the 1860s and 1870s, connected in part to the gold rush, Irish immigration waned, and the focus was on Ulster Protestants rather than southern Catholics, Phillips and Hearn, 58-64.

${ }^{21}$ James Belich. Making Peoples. A History of the New Zealanders from Polynesian Settlement to the end of the Nineteenth Century. Auckland: 1996, 315.
} 
implication of this is that Scots, and those of Scottish descent, were prominent in promoting divorce law reform in New Zealand. ${ }^{22}$ Scots were foremost amongst those who supported divorce law reform by drawing on their knowledge of the more liberal Scottish divorce law combined with Scottish enlightenment ideals about women. Scotland had allowed divorce as a common law right since 1560, whereas the first divorce statute was only passed in England and Wales in $1857 .{ }^{23}$ Liberal attitudes to law reform did not necessarily lead to higher divorce rates. Presbyterians were not overrepresented in divorce statistics in New Zealand. Dunedin, a primarily Scottish settlement, had the lowest divorce rate of the four main cities from 1921.

In this study I will undertake the task, described recently by Angela Wanhalla, of 'complicating national identity' by looking across national borders at family, community and gender through the lens of divorce. ${ }^{24}$ Wanhalla also argues that existing studies of family and community are bound to the nineteenth century and that the scholarship needs to move into the twentieth century, which this thesis does. ${ }^{25}$ The thesis draws upon important studies of divorce in societies comparable to New Zealand, particularly from Britain, the settler dominions, and the United States to show both the similarities and the differences between divorce in these societies. ${ }^{26}$ Social historians have commented on

\footnotetext{
${ }^{22}$ For example, politicians Robert Stout, John MacGregor, Robert McNab, Peter Fraser and feminist Margaret Sievwright. See Chapter One for further details of these individuals and their respective biographies in the Dictionary of New Zealand Biography (DNZB) available at http://www.dnzb.govt.nz.

${ }^{23}$ Phillips, Putting Asunder, 60-62. It was possible to obtain a divorce in England and Wales prior to 1857 by an Act of Parliament, but this was an extremely expensive and difficult process.

${ }^{24}$ Wanhalla, 464.

25 Ibid.

${ }^{26}$ As well as Phillips' 1988 overview of divorce in western societies, Putting Asunder, there are a number of major studies of divorce. For example see, Henry Finlay. To Have But Not To Hold. A History of Attitudes to Marriage and Divorce in Australia 1858-1975. Sydney: 2005; Hilary Golder. Divorce in New South Wales. Kensington: 1985; James Snell. In the Shadow of the Law: Divorce in Canada, 1900-1939. Toronto: 1991; Lawrence Stone. Road to Divorce: England 1830-1987. Oxford: 1990; Gail Savage. "“A State of Personal Danger": Domestic Violence in England, 1903-1922', in Assaulting the Past: Placing Violence in Historical Context, ed. Katherine D. Watson. Newcastle: 2007, 269-85; Gail Savage. 'Divorce and the Law in England and France Prior to the First World War'. Journal of Social History 21, no.3 (1988): 499-513; Gail Savage. 'Erotic Stories and Public Decency: Newspaper Reporting of Divorce Proceedings in England'. The Historical Journal 41, no.2 (1998): 511-28; Gail Savage. "'Intended Only for the Husband": Gender and Class and the Provision for Divorce in England, 1858-1868', in Victorian Scandals: Representations of Gender and Class, ed. Kristine Ottesen Garrigan. Athens: 1992, 11-42; Gail Savage. "“The Magistrates are Men:” Working Class Marital Conflict and Appeals from the Magistrates' Court to the Divorce Court After 1895', in Disorder in the Court, eds. George Robb and Nancy Erber. New York: 1999, 231-49; Gail Savage. 'The Operation of the 1857 Divorce Act, 1860-1910. A Research Note'. Journal of Social History 16, no.4 (1983): 103-10; Gail Savage. "“The Wilful Communication of a Loathsome Disease": Marital Conflict and Venereal Disease in Victorian England'. Victorian Studies 34, no.1 (1990): 35-54; Leah Leneman. Alienated Affections: The Scottish Experience of Divorce, 1684-1830. Edinburgh: 1998; Basch; Kristin Celello. Making Marriage Work. A History of Marriage and Divorce in the Twentieth-Century United States. Chapel Hill: 2009; Elaine Tyler May. Great Expectations. Marriage
} 
the changes which occurred during the first half of the twentieth century that contributed to the increasing rate of divorce in western countries. These factors include industrialization, urbanization, increasing mobility, women's involvement in the paid workforce, the changing nature of the patriarchal family and rising expectations of marriage. ${ }^{27}$ What is more difficult is to specify exactly how these factors contributed to rising divorce rates and which factors were the most important. Divorce became possible in New Zealand, as it did in many other similar societies, at a time when changes on a major, sometimes described as a revolutionary, scale were occurring in family size, marriage rates and life span. Marriages in the nineteenth century were often interrupted by the death of a spouse, but in the twentieth century marriages were likely to last for a much longer period of time. For some this was not a viable situation, and these people turned to divorce to end their marriages.

Many historians have explained divorce as a part of modernity. With modernity came mass media as well as expert professional commentary on marriage, its ills and its pleasures, its fortunes and fate. Caroline Daley has termed this phenomenon as the 'twin impulses of modernity' - surveillance and bureaucratisation. ${ }^{28}$ Olssen claims that New Zealand had become 'modern' by the end of the 1920s. He specifically cites more common divorce as evidence of modernity, and the frequency of divorce as evidence of a 'relaxation of traditional standards of sexual behaviour'. ${ }^{29}$ Writing of the American scene, Beth Bailey explains: 'Never before was such a large percentage of the population aware of the magnitude of change in the values and institutions of their society' ${ }^{30}$ This growing awareness, consideration and discussion of issues such as the purpose of marriage led to a questioning by some people about the satisfaction that they found within their marriages, resulting in the decision to divorce. Judy Giles has argued that such changes brought benefits but, 'these changes also brought anxiety, loss and insecurity' which may have also undermined the stability of some relationships while making others unwilling to

and Divorce in Post-Victorian America. Chicago: 1980; J. Herbie DiFonzo. Beneath the Fault Line - The Popular and Legal Culture of Divorce in Twentieth-Century America. Charlottesville: 1997; Glenda Riley. Divorce: An American Tradition. Lincoln, Neb: 1991.

${ }^{27}$ Riley, 5. For the New Zealand context see Erik Olssen. 'Towards a New Society', in The Oxford History of New Zealand, $2^{\text {nd }}$ ed. ed, Geoffrey Rice. Auckland: 1992, 254.

${ }^{28}$ Caroline Daley. 'Modernity, Consumption and Leisure', in The New Oxford History of New Zealand, ed. Giselle Byrnes. Melbourne: 2009, 434.

${ }^{29}$ Olssen. 'Towards a New Society', 254.

${ }^{30}$ Beth L. Bailey. From Front Porch to Back Seat. Courtship in Twentieth Century America. Baltimore: $1988,114$. 
accept their partners' decisions to seek divorces. ${ }^{31}$ Analysis of a large number of divorce cases over time enables an exploration of the contradictory desires, impulses and emotions which propelled at least one partner to petition for divorce, with the acquiescence or the opposition of the other. How was the 'modernity' of which Olssen, Daley, Bailey and Giles write about, lived in the day-to-day world of people alive in the early twentieth century?

Divorce can also be viewed within another debate about the character of New Zealand society in the early twentieth century. New Zealand historians have presented opposing views on the subject of what Chris Brickell has termed the 'expression/repression' debate. ${ }^{32}$ James Belich, in his general history of twentieth-century New Zealand has argued that a 'great tightening' occurred between 1880 and $1920 .{ }^{33}$ In particular, he argues that one aspect of this tightening was a secular, moral crusade 'for purity and virtue'. ${ }^{34}$ Drawing on alcohol and gambling regulation and an active prohibition movement as prominent features of this 'tightening' his argument acknowledges that the tightening was 'contested, resisted and subverted', particularly by the 'lower classes'. The great tightening, however, does not adequately explain the history of divorce in New Zealand during this period. ${ }^{35}$ While it was primarily working-class couples who divorced in New Zealand, rather than reading this as a resistance of middle-class ideals, it should be read as an acceptance of the importance of marriage and the need to have one's relationship acknowledged in law. Most people who divorced re-married, and those who did not divorce, could not remarry and so their subsequent relationships and any children they had existed outside the law. On the 'expression' side, Caroline Daley has argued that New Zealand historians have chosen to focus on puritans rather than those who enjoyed 'pleasures of the flesh'. ${ }^{36}$ Her argument also deserves consideration. Certainly there are individuals in the divorce case files, notably many of those who committed adultery, who could be identified as pleasure seekers, but the situation is much more complex. Belich

\footnotetext{
${ }^{31}$ Judy Giles. The Parlour and the Suburb. Domestic Identities, Class, Femininity and Modernity. Oxford: 2004, 4-5.

${ }^{32}$ Chris Brickell, 'Sexuality, Morality and Society', in The New Oxford History of New Zealand, ed. Giselle Byrnes. Melbourne: 2009, 467.

${ }^{33}$ Belich, Paradise Reforged. A History of the New Zealanders from the 1880s to the Year 2000. Auckland: 2001, 121-25.

${ }^{34}$ Ibid., 122.

${ }^{35}$ Ibid., 157, 168.

${ }^{36}$ Caroline Daley. 'Puritans and Pleasure Seekers', in Sexuality Down Under. Social and Historical Perspectives, eds. Allison Kirkman and Pat Moloney. Dunedin: 2005, 47-62.
} 
and Daley's debate is limited to the degree to which New Zealanders were sexually inhibited. ${ }^{37}$ Not all those who committed adultery did so primarily for sexual gratification. For some, especially women, it was a way of forming a relationship with a potential breadwinner after their husband had left. The majority of divorces during the first half of the twentieth century were granted on the ground of separation of three years or more, were not contested, and little of the relationship was revealed to the court. Rather than indicating a pleasure-seeking approach to life, they indicate a pragmatic approach, outlined above, whereby divorce allowed re-marriage and legal conformity.

Historians have debated the impact that legal grounds for divorce have on the divorce rate. C. James Richardson has argued that liberalization of divorce law in Canada - which in the first half of the twentieth century usually meant extending the grounds for divorce resulted in an increase in the rate of divorce. Already 'broken' marriages could become legally dissolved while liberalisation also gave greater access to a 'wider segment of the population'. ${ }^{38}$ Elaine Tyler May, on the other hand, has argued that legal changes have little or no impact on the rate of divorce. Instead, she claims that people make their situations fit the law. ${ }^{39}$ New Zealand offers a good case study to test these claims because Parliament did liberalise the divorce law in a series of innovative legal changes. In 1898 the law was changed by the Liberal government which had an 'established a tradition of pragmatic interventionism'. ${ }^{40}$ The new law enabled men and women to petition for divorce on equal grounds for the first time as a tacit recognition of women's attainment of political and civil rights. Over the following six decades other legal changes occurred, until, by the end of 1959 , over 47,500 divorces had been granted by the New Zealand Supreme Court. Why did New Zealand couples use these laws with increasing frequency from 1898 to 1959 ? In the process, they created what Hendrik Hartog has discussed as a change from 'a legal culture shaped by a deeply held and centuries-old faith that marriage was a permanent hierarchal relationship that made men into husbands and women into wives,' into a 'legal culture that also offered unprecedented possibilities for escape from that permanent relationship'. ${ }^{4}$

\footnotetext{
${ }^{37}$ Brickell, 'Sexuality, Morality and Society', 467.

${ }^{38}$ C. James Richardson. 'Divorce and Remarriage', in Families. Changing Trends in Canada. $4^{\text {th }}$ ed. ed, Maureen Baker. Toronto: 2001, 212.

${ }^{39}$ May, 5.

${ }^{40}$ David Hamer. 'Centralization and Nationalism (1891-1912)', in The Oxford Illustrated History of New Zealand, $2^{\text {nd }}$ ed., ed. Keith Sinclair. Auckland: 1996, 126.

${ }^{41}$ Hendrik Hartog. Man and Wife in America. A History. Cambridge, Mass: 2000, 1-2.
} 
New Zealand's changing divorce law can be seen in the wider frame of what has been identified as family law. ${ }^{42}$ In 1966 Bruce Cameron in the Encyclopaedia of New Zealand noted that '[o]ne persistent theme is a preoccupation with the welfare of the family, particularly wives and children. In this sphere New Zealand has never been content simply to follow others'. ${ }^{43}$ J.L. Robson reiterated this sentiment the following year in the second edition to his work on the development of New Zealand law. Robson argued,

the New Zealand legislature has shown itself in the sphere of family law ready to borrow freely from a diversity of sources, to innovate boldly and in the interests of humanity and practical justice to discard traditional rules, policies and approaches.... New Zealand family law is perhaps somewhat closer to that of Australia, and there has from time to time been a good deal of reciprocal borrowing, but even here the divergences are not inconsiderable. ${ }^{44}$

This, again points to some of the unique aspects of New Zealand law, as well as the more rapid extension of the grounds for divorce compared with England, Canada and even some of the Australian states. The development of New Zealand's divorce law demonstrates the willingness of successive New Zealand governments to pass legislation that was comparatively liberal in the context of Britain and the Dominions.

The best known ground for divorce is adultery. Studies of divorce inevitably also become studies of sexuality - its expression, regulation and changing conceptualisation. ${ }^{45}$

\footnotetext{
${ }^{42}$ Peter Spiller et al. A New Zealand Legal History. Wellington: 1995, 94.

${ }^{43}$ Bruce Cameron. 'Reforming the Law', in An Encyclopaedia of New Zealand, edited by A.H. McLintock, originally published in 1966. Te Ara - the Encyclopedia of New Zealand, updated 23 April 2009. URL: http://www.teara.govt.nz/en/1966/law-history-of/4.

44 J.L. Robson, ed. New Zealand. The Development of its Laws and Constitution. $2^{\text {nd }}$ ed. London: 1967, 442.

${ }^{45}$ There is a wide literature on sexuality in New Zealand. See Bronwyn Dalley. 'Lolly Shops "of the redlight kind" and "soldiers of the King": Suppressing One-Woman Brothels in New Zealand, 1908-1916'. NZJH 30, no.1 (1996): 3-23; Bronwyn Dalley. "Fresh Attractions": White Slavery and Feminism in New Zealand, 1885-1918'. WHR 9, no.3 (2000): 585-606; Bronwyn Dalley. 'Criminal Conversations: Infanticide, Gender and Sexuality in Nineteenth-Century New Zealand', in The Gendered Kiwi, eds. Caroline Daley and Deborah Montgomerie. Auckland: 1999, 63-85; Tracy C. Tulloch. 'State Regulation of Sexuality in New Zealand, 1880-1925'. PhD thesis, University of Canterbury, 1997; Philip J. Fleming. “"Shadow over New Zealand": The Response to Venereal Disease in New Zealand 1910-1945'. PhD thesis, Massey University, 1989; Philip Fleming. 'Fighting the "Red Plague": Observations on the Response to Venereal Disease in New Zealand 1910-1945'. NZJH 22, no.1 (1988): 56-64; Chris Brickell. 'Same-Sex Desire and the Asylum: A Colonial Experience'. NZJH 39, no.2 (2005): 158-78; Barbara Brookes. 'Housewives' Depression. The Debate over Abortion and Birth Control in the 1930s'. NZJH 15, no.2 (1981): 115-34; Barbara Brookes. 'A Weakness for Strong Subjects: The Women's Movement and Sexuality'. NZJH 27, no.2 (1993): 140-56; Charlotte Macdonald. 'The "Social Evil". Prostitution and the Passage of the Contagious Diseases Act (1869)', in Women in History. Essays on European Women in New Zealand, eds. Barbara Brookes et al. Wellington: 1986, 13-33; Daley, 'Puritans and Pleasure Seekers'; Brickell, 'Sexuality, Morality and Society'; Jane Tolerton. Ettie: A Life of Ettie Rout. Auckland: 1992; Stevan Eldred-Grigg. Pleasures of the Flesh: Sex and Drugs in Colonial New Zealand 1840-1915. Wellington: 1984; Chris Brickell. Mates and Lovers: A History of Gay New Zealand. Auckland: 2008.
} 
Historians of sexuality have seen the first half of the twentieth century as a time of major change, and in particular have focused on the influence of both World Wars I and II as points of practical change and heightened debate. John D'Emilio and Estelle Freedman, writing about the United States, have argued that from the late nineteenth century to World War I the pace of change increased, and there was a growing emphasis on pleasure and gratification. ${ }^{46}$ This, combined with the notion of 'living for the moment', led to an increasing number of young people engaging in pre-marital sex. Further, after the World War I there was an increase in the publication of marriage guides that encouraged people to seek sexual satisfaction within marriage, and to view the sexual relationship as an essential element of a marriage. Marilyn Lake has discussed how war is a 'gendering activity' and more specifically how having foreign (American) troops stationed in a country 'has the effect of sexualizing the local female population'. ${ }^{47}$ Her analysis of the situation in Australia, could equally apply to New Zealand where American troops were also stationed. Bradbury, looking at Canada, has argued that post-World War II there was an even greater emphasis placed on sex in marriage, along with love and romance. ${ }^{48}$

As was evident in the British constitutional crisis of 1936, when Edward VIII abdicated in order to marry the twice-divorced American Wallis Simpson, divorce also involved religious views about marriage. The Christian church's view of marriage remained largely unmoved by legal changes and social trends. Attention will therefore be paid to religious affiliations to the extent to which those are visible within court records, and to the shift which Phillips has described from marriage resting on 'theological foundations to secular emphases based on social and personal considerations' as part of a growing secularisation of New Zealand society which continued after the period covered in this analysis. ${ }^{49}$

Divorce cases and public debates about divorce reveal as much about people's notions of marriage as they do about the reasons for divorce. While marriage may seem to be a private relationship between two people (a man and a woman) it was also a public institution. As Nancy Cott explains, 'in the form of the law and state enforcement, the public sets the terms of marriage, says who can and cannot marry, who can officiate, what

\footnotetext{
${ }^{46}$ D'Emilio and Freedman, 172.

${ }^{47}$ Marilyn Lake. 'Female Desires: The Meaning of World War II'. AHS 21, no.95 (1990): 274-75.

${ }^{48}$ Bettina Bradbury. 'Social, Economic, and Cultural Origins of Contemporary Families', in Families. Changing Trends in Canada. $4^{\text {th }}$ ed. ed, Maureen Baker. Toronto: 2001, 90.

${ }^{49}$ Phillips. Putting Asunder, 191.
} 
obligations and rights the agreement involves, whether it can be ended and if so, why and how' ${ }^{50}$ This then raises the question, why does the state have such a major interest in marriage (and consequently divorce)? At the same time the actual space where the marriage was played out was 'the home', generally considered to be a private space, but still under public surveillance. Barbara Brookes has found in her study of a marital homicide in South Dunedin that 'all marriages were open to public view and community assessment in ways that made them central to understandings of gender in society'. ${ }^{51}$ Similarly, Shani D’Cruze in examining a domestic homicide in 1930s England has argued that such trials 'provided significant moments when fractures in the values and aspirations of (often) respectable private lives were held up for exhaustive public scrutiny, ${ }^{52}$ She goes on to contextualise domestic and courtship homicide cases with celebrated divorce and bigamy cases, which 'offered comment on marriage, (hetero)sexual relations, and domesticity' which was 'ubiquitous and disproportionate'. 53

The study draws attention to newspapers which operated as a court of public opinion. James Hammerton's insight about newspaper reporting of divorce cases in England is explored in the New Zealand case setting. Hammerton suggests that newspapers made the putatively private space of family life into 'public property subject to regulation' and opened 'marital behaviour of both sexes to more scrutiny' ${ }^{54}$ Like the British press, New Zealand newspapers, but also suspicious spouses, neighbours, extended family, detectives, and even children engaged in 'intrusive scrutiny and surveillance' as part of the divorce process. ${ }^{55}$ Court records and press reports thus enable the construction of a collective picture of married life in New Zealand during the first half of the twentieth century, at least for those marriages whose partners aired their difficulties in court.

To address the questions this study seeks to answer in a systematic and comprehensive way the thesis is built around an analysis of a random sample of 2,195 divorce case files from the Wellington Supreme Court from 1898 until 1947. This comprises what will be referred to as the Wellington Divorce Database. In New Zealand, divorce files which are

\footnotetext{
${ }^{50}$ Nancy Cott. Public Vows. A History of Marriage and the Nation. Cambridge, Mass: 2000, 2.

${ }^{51}$ Brookes, 354.

${ }^{52}$ Shani D'Cruze. 'Intimacy, Professionalism and Domestic Homicide in Interwar Britain: the case of Buck Ruxton'. WHR 16, no.5 (2007): 702.

${ }^{53}$ Ibid., 716.

${ }^{54}$ Hammerton, 102.

55 Ibid., 102.
} 
more than 60 years old are open to the public, but those files which are less than 60 years old are closed, and this determined the end date of the sample. The sample is the result of selecting every fourth file out of a total of more than 8,000 petitions for divorce from what is an almost entirely complete legal record. ${ }^{56}$ Individuals featuring in the case files have been identified by their first names and the initial of their family name unless they are relatively well-known and it is already well established in the public record that they obtained a divorce at some point in their life. Unlike today where dissolution cases are heard in the privacy of the Family Court, divorces were heard in open court throughout this study period, unless a special order was made by the judge. Newspapers, law journals and other publications were able to report widely on cases and named the individuals involved. ${ }^{57}$ The decision not to use individuals' full family names is an acknowledgement of the potentially sensitive nature of some of the court records, although they were heard in open court at the time, and are accessible to the public at the Archives New Zealand offices.

Wellington had the highest divorce rate among the major urban centres in New Zealand, making its court records an obvious choice as a source for studying the nature and practice of divorce in New Zealand. The files allow for a quantitative and a qualitative study of divorce in New Zealand during the first half of the twentieth century. Miles Fairburn and Erik Olssen have argued that New Zealand is 'richly endowed with raw systematic data on aspects of the lives of large numbers of people who are otherwise "hidden" from history', despite census manuscripts being destroyed. ${ }^{58}$ The divorce case files are one example of such a source. Fairburn and Olssen have claimed that the potential of quantitative history in New Zealand has largely been untapped, especially in relation to the twentieth century'. ${ }^{59}$ Quantitative methodologies have been used to evaluate broad trends and qualitative methodologies to explore the construction of gender identities and norms, sexuality, and surveillance.

\footnotetext{
${ }^{56}$ In contrast, the records of the Magistrates' Court, where numerous marital disputes were also heard, are often incomplete or non-existent. See Chris Brickell. 'Court Records and the History of Male Homosexuality'. Archifacts (2008): 26-27.

${ }^{57}$ Chapter Five explores this in more detail, including the restrictions placed on newspapers from 1958.

${ }^{58}$ Miles Fairburn and Erik Olssen. 'Introduction', in Class, Gender and the Vote. Historical Perspectives from New Zealand, eds. Fairburn and Olssen. Auckland: 2005, 7-8.

${ }^{59}$ Ibid., 8.
} 
In a collection of essays edited by Franca Iacovetta and Wendy Mitchinson, a number of Canadian historians have discussed the value of using case files to study social history. ${ }^{60}$ As Iacovetta and Mitchinson have argued, case files are reflective of an aspect of the modern world - 'the desire to keep track of people and have a tracking record' ${ }^{61}$ Case files also allow historians to 'recover the lives of the less powerful' which is particularly important when writing a social history. ${ }^{62}$ Unlike the women in the mothers' allowance case files studied by Margaret Hillyard Little, petitioners and sometimes respondents had the 'opportunity to submit their own words into the case file'. ${ }^{63}$ As divorce was a civil issue, at least one spouse elected to go to court as opposed to criminal cases when the state, in various forms, forced individuals into court. Moreover, while the file held by the court was shaped by requirement of evidence and legal documents, individuals had greater control of what was in the file. Litigants could choose to offer evidence, but they were also advised by a lawyer. Ultimately the files were produced by a legal system and were shaped by legal ideologies and legal process affected events. ${ }^{64}$

The files provide an array of information, some containing much more evidence than others. Almost all files contained the marriage certificate, petition for dissolution of marriage, decree nisi and decree absolute. These four documents reveal the bride and groom's name (including the bride's maiden name), age at marriage, place of marriage, groom's occupation, bride and groom's status prior to the marriage (spinster/bachelor/divorced/widowed), birthplace, father's name and occupation, mother's name and maiden name, reason for the petitioner wanting a divorce, and details of the situation. When the petitioner was male and if the reason for the petition was adultery normally a co-respondent (the man the wife had been having a sexual relationship with) was named. All the places the couple lived during their marriage were listed, along with names and dates of birth of any children of the marriage, custody decisions, and the issue of costs - how much was to be paid and by whom. Some files included details of attempts to locate a spouse who has disappeared (newspaper advertisements, etc.), failure of the

\footnotetext{
${ }^{60}$ Franca Iacovetta and Wendy Mitchinson, eds. On the Case: Explorations in Social History. Toronto: 1998.

${ }^{61}$ Ibid., 4.

${ }^{6}$ Ibid.

${ }^{63}$ Margaret Hillyard Little. 'Ontario Mothers' Allowance Case Files as a Site of Contestation', in On the Case: Explorations in Social History, eds. Franca Iacovetta and Wendy Mitchinson. Toronto: 1998, 227.

${ }^{64}$ Jim Phillips. 'Why Legal History Matters'. Victoria University of Wellington Law Review 41, no.3 (2010): 293-316.
} 
respondent or co-respondent to pay costs, the court transcript, and correspondence from the respondent (normally a denial of the claims of the petitioner). Later cases often contain an agreement for separation. These documents were relatively detailed, drawn up by lawyers and included arrangements agreed to by both spouses, such as custody and alimony and in some cases the division of property.

While the majority of the cases involved couples living in Wellington or nearby, many were not originally from Wellington, and some had very itinerant lives. In a few cases only one spouse lived in Wellington while the other lived somewhere else in New Zealand or overseas. In these cases, it was sometimes the petitioner who was living in Wellington and sometimes it was the respondent. Less frequently, but more intriguingly, there were some cases where neither spouse was living in Wellington and there appears to be no obvious reason for the case being heard in the Wellington Court other than perhaps the desire to escape public scrutiny at a local level. Official statistics, which cover the entire country, have been used in order to highlight any differences between the Wellington pattern, and the New Zealand pattern more generally.

The chronological limits for the study saw divorce go from being almost statistically irrelevant to occurring with increasing regularity. The first half of this study period, from 1898 until the early 1920s was 'an era of prosperity' that ended with a worldwide slump in dairy and wool prices. ${ }^{65}$ The economic downturn lasted through the 1920 s and then was made worse with the Great Depression, which affected the economic situation in New Zealand for most of the 1930s. Then a second phase of prosperity was entered into with the beginning of World War II and this lasted until the end of this study period in the 1950s, continuing, of course, into the 1960s, which will not be covered in this thesis. There was also industrial unrest 1908-1913, sectarian conflict, 1911-1920, World War I, and the 1918 influenza epidemic. The economic fluctuations of the 1920s and the Depression of the 1930s were followed by World War II and then the onset of the Cold War and the 1951 Waterfront Lockout. ${ }^{66}$ During much of this period eugenic thought

\footnotetext{
${ }^{65}$ Tom Brooking. 'Economic Transformation', in The Oxford History of New Zealand, $2^{\text {nd }}$ ed. ed. Geoffrey Rice. Auckland: 1992, 230.

${ }^{66}$ Miles Fairburn and S.J. Haslett. 'Stability and Egalitarianism: New Zealand, 1911-1951', in Class, Gender and the Vote. Historical Perspectives from New Zealand, eds. Miles Fairburn and Erik Olssen. Otago: 2005, 15.
} 
fuelled concerns with the birth rate and the 'fitness' of the New Zealand population. ${ }^{67}$ With regards to divorce, and familial structures, it is clear that both world wars were catalysts for long-term changes. The influence of other events is less clear, both from the statistics and the divorce files, although arguably all would have impacted upon some marriages to a degree.

The thesis consists of eight chapters and an epilogue/conclusion. Chapter One surveys the marriage and divorce law between 1898 and 1959 paying attention to those elements of the law in New Zealand that were unique compared with other similar jurisdictions. The legal framework establishing the grounds for divorce established the parameters for those New Zealanders intent on ending their marriages and gave them choices and set limits about what they might reveal before the court, newspapers, and the public. Chapter Two presents the major trends in divorce over the whole period under study using both official statistics and the Wellington Divorce Database. Major trends over time are outlined. Chapter Three focuses on how the world wars shaped the decision to divorce in light of the dramatic increase in the incidence of divorce during and after the wars. Chapter Four explores the impact of class and economics on New Zealanders' decision to divorce using occupations as evidence of class affiliations, and the methodology used in the analysis. It also considers the awards for costs and damages made in cases. The division of property, and the role of charitable aid and later the social welfare system in providing financial support for wives (and especially those with children) who no longer had male support as a result of divorce is considered. Chapter Five analyses the role of surveillance and scandal in monitoring people's behaviour - especially sexual behaviour. It traces the use of surveillance to gather information about the other party whether by the suspicious spouse, family members, friends, neighbours, or private detectives. It also considers the self-appointed role of newspapers, particularly the populist weekly newspaper Truth, in exposing the 'guilty' parties in divorce cases. Such action received implicit political support by the refusal of Parliament, until a pivotal debate in 1958, to keep such details confidential. The equivalent measure was introduced much earlier in Britain. The chapter will thus reveal the blurring of the private and public, and how informal and formal systems operated to regulate sexuality and morality by imposing the penalty of public exposure upon those who violated their marriage vows.

\footnotetext{
${ }^{67}$ Mein Smith, 119-22.
} 
Chapter Six focuses on how marriage created and enforced gender identities and norms. It examines the causes of tensions in many marriages about conflicting notions of gender responsibilities and expectations, in contrast to the available legal grounds for divorce. The divorce records reveal conflicts over finances, social activities, the performance of household duties, the husband's provider role and religion. The chapter then discusses the use of the legal grounds for divorce of drunkenness, cruelty, failure to maintain and insanity as among the most gendered grounds used in divorce petitions. Chapter Seven focuses on children as involved not only in the decision to marry but the decision to divorce. Arguably their parents' divorce had at least as great an impact on their lives as it did on their parents'. It looks at children's role in the divorce itself and the subsequent conflicts over custody including the involvement of the wider or extended family. Chapter Eight looks at sexuality and emotions both in marriage and divorce as it traces the changing expectations about sexual fulfilment in marriage and how this contributed to the increasing number of divorces. The records reveal diverse desires about the appropriate frequency of sexual intercourse, the role of jealously and suspicion, and the use of restitution of conjugal rights as a device to attain a divorce to circumvent the more time-consuming requirements. The Epilogue and Conclusion draws on newspaper and magazine sources to cover developments which occurred after the period accessible through the Wellington Divorce Database, 1947 into the 1950s. It examines the origins and development of Marriage Guidance in New Zealand from 1948 as a direct response to the high divorce rate during and immediately after World War II and considers the therapeutic turn to experts as well as the role of the New Zealand government in trying to 'keep people married'. The epilogue takes the study beyond the post-World War II 'spike' in divorce to explore the consequences of this dramatic increase.

This thesis contributes to the history of marriage and divorce in New Zealand by showing how New Zealanders utilised the law in order to end their marriages. It situates New Zealand patterns within the broader context of Australian, Canadian and English studies as well as the United States. It explores aspects of sexual behaviour and assumptions about sexuality which reveal a growing focus on marriage as a sexual relationship resulting in a higher likelihood of divorce when expectations about sexual satisfaction were not met. It examines the interaction between intimacy and exposure in the divorce courts and the media as recorded in divorce case files and news reports. It looks at how 
gender, class, religion, and ethnicity contributed to the decision to divorce. It considers the impact of major historical events such as war upon apparently personal and private decisions. In short, the study explores why the divorce rate increased during the first half of the twentieth century in New Zealand, and what this tells us about the institution of marriage and the institution of the family more generally but it also broadens its scope to discuss important aspects of the social and cultural history of New Zealanders. 


\section{Chapter One}

\section{The Evolution of the Divorce Law}

In 1898, and then during the first half of the twentieth century, the New Zealand Parliament widened the grounds for divorce, allowing more couples to bring their marriage to a legal end. Changes, and attempted changes, to divorce laws often stirred up controversy in the nineteenth century because divorce challenged the moral, religious and social order, in which marriage as an indissoluble union, constituted a fundamental institution. If marriage was no longer deemed a lifelong relationship, opponents of divorce argued that this would have an adverse effect on society as a whole. From the 1860 s there were changes to laws relating to women, marriage and property. These included the enactment of the first divorce statute in 1867, along with a series of Married Women's Property Acts between 1860 and 1884, and the 1898 Divorce Act which made the ground for petitioning for divorce equal for husbands and wives. ${ }^{1}$ The situation of women, and especially married women, before the law was markedly different by the 1890s than it had been in the 1860s. ${ }^{2}$ Many of the disabilities of women before the law had been removed.

\footnotetext{
${ }^{1}$ Divorce and Matrimonial Causes Act 1967 (31 Victoriae 1867 No. 94); Married Women's Property Protection Act 1860 (24 Victoriae 1860 No. 9); Married Women's Property Protection Act 1870 (33 and 34 Victoriae 1870 No. 37); Married Women's Property Protection Act 1880 (44 VIC 1880 No. 14); Married Women's Property Act 1884 (48 VIC 1884 No. 10); Married Women's Property Act 1894; Divorce Act 1898 (62 VIC 1898 No. 42).

${ }^{2}$ Amy Dru Stanley has explored the public discourse on the primacy of contract in nineteenth-century America and how the abolition of slavery influenced feminist arguments regarding women's rights, particularly to their own earnings. See, Amy Dru Stanley. From Bondage to Contract. Wage Labor, Marriage, and the Market in the Age of Slave Emancipation. Cambridge: 1998. For examples of women's attempts to extend their legal identity see, Bettina Bradbury. 'From Civil Death to Separate Property: Changes in the Legal Rights of Married Women in Nineteenth-Century New Zealand'. NZJH 29, no.1 (1995): 40-66; Bettina Bradbury. 'Colonial Comparisons: Rethinking Marriage, Civilisation and Nation in the Nineteenth-Century White Settler Societies', in Rediscovering the British World, eds. Phillip Buckner and R. Douglas Francis. Calgary: 2005, 135-57; Rosalind Atherton. 'New Zealand's Testators' Family Maintenance Act of 1900 - the Stouts, the Women's Movement and Political Compromise'. Otago Law Review, no.7 (1990): 202-21. For the international literature see, Norma Basch. 'Invisible Women: The Legal Fiction of Marital Unity in Nineteenth-Century America'. FS 5, no.2 (1979): 346-66; Mary Lyndon Shanley. Feminism, Marriage, and the Law in Victorian England, 1850-1895. Princeton: 1989; Lee Holcombe. Wives and Property. Reform of the Married Women's Property Law in Nineteenth-Century England. Oxford: 1983; Constance Backhouse. Petticoats \& Prejudice. Women and Law in NineteenthCentury Canada. Toronto: 1991; Carole Shammas. 'Re-Assessing the Married Women's Property Acts'. JWH 6, no.1 (1994): 9-30.
} 
While this thesis primarily focuses on the period from 1898, it is necessary to discuss the first New Zealand divorce law which was passed in 1867 in order to contextualise the importance of the 1898 Divorce Act. ${ }^{3}$ The removal of the double standard from divorce law relating to adultery in 1898 formed part of a move towards the removal of 'the most blatant forms of legal discrimination' against women which occurred between the 1880s and $1910 .{ }^{4}$ Divorce cases were heard in the Supreme Court, usually by a judge alone, although in some cases a jury was also used. After the significant extension to the grounds for divorce in 1898, the most important legislative change occurred in 1920 when separation of three years or more became a new ground for divorce. This was arguably the most significant transformation to the divorce law until the Family Proceedings Act 1980 made irreconcilable differences the only ground for dissolution. ${ }^{5}$

As well as considering the changes in New Zealand divorce legislation for the period covered by this thesis, New Zealand law will be compared to England, the Australian states, and the Canadian provinces. New Zealand divorce law was originally derived from English law; hence comparisons with other countries' divorce laws with a similar heritage illuminate the distinctive aspects of New Zealand's development in regards to divorce legislation. Among the reasons for these differences to be considered are the influence of Maori marriage laws and the implication of these laws for divorce cases involving Maori whose marriages were not formally registered. Finally, this chapter discusses the law of domicile and nationality and how the two relate to divorce, most notably for women, along with changes made in Britain and the dominions to rectify the problem of women being left stateless after divorce. Access to, and the practice of laws pertaining to, marriage and divorce helped to define women's citizenship in New Zealand in the twentieth century. The benefits and pitfalls women gained and lost from marriage and

\footnotetext{
${ }^{3}$ Divorce Act 1898 (62 VIC 1898 No. 42).

${ }^{4}$ Erik Olssen. 'Towards a New Society', in The Oxford History of New Zealand, $2^{\text {nd }}$ ed. ed, Geoffrey Rice. Auckland: 1992, 265. For example, The Married Women's Property Act 1884; women's franchise in 1893; The Divorce Act 1898; the repeal of the Contagious Diseases Act in 1910; and the enactment of a law allowing women to stand for parliament in 1919.

${ }^{5}$ Family Proceedings Act 1980 (1980 No. 94). See also Family Courts Act 1980 (1980 No. 161). Although beyond the scope of this study, the Matrimonial Property Act 1976 and the Family Proceedings Act 1980, were the two most important legislative changes to divorce law in New Zealand in the second half of the twentieth century, and the principles espoused in these acts continue to shape contemporary New Zealand family law. See Justine L. Jenkins. 'Mine, Yours, Ours. An Economic Analysis of the Development of Matrimonial Property and Divorce Law in New Zealand 1880-1980'. MA thesis, University of Auckland, 2001.
} 
divorce, and fears about the institution of marriage comprise a useful point of comparative gender analysis.

Changes in divorce law challenged assumptions about the law itself and how judicial decisions should be made. The New Zealand legal system, based on the British system, assumed an adversarial situation between litigants or, in the case of divorce, petitioners and respondents. Divorce law incorporated the concept of fault. The petitioner had to show himself or herself as the 'innocent' party and the respondent as the partner responsible for the demise of the relationship. During the first half of the twentieth century in New Zealand, however, Parliament altered the concept of fault, albeit not overtly, by the introduction of such grounds as insanity and mutual separation of three years or more as grounds for divorce. The introduction of the latter ground initially provoked little debate in Parliament. The question of fault began to disappear, but could still be brought into the case should the petitioner wish to accuse the respondent of having committed one of several misdeeds deemed to have dissolved the contract between the two parties. As this study demonstrates, the traditional adversarial approach co-existed with a newer, but unofficial, no-fault form of divorce which the 1920 change in the law had introduced.

The Divorce and Matrimonial Causes Act 1867 provided New Zealand with its first statute divorce law. ${ }^{6}$ Prior to this, people living in New Zealand could only obtain a divorce by an Act of Parliament or by returning to England and petitioning for divorce. ${ }^{7}$ The British Parliament had passed the first statute divorce law for England and Wales in 1857 (Scotland had a different and much older divorce law). ${ }^{8}$ The 1857 measure allowed husbands to petition for divorce in the case of their wife's adultery and wives to petition for divorce where their husband had committed aggravated adultery - that is adultery coupled with cruelty, incest or another exacerbating factor. The English statute also established a Divorce Court which sat only in London and all petitions for divorce had to

\footnotetext{
${ }^{6}$ Divorce and Matrimonial Causes Act 1967 (31 Victoriae 1867 No. 94).

${ }^{7}$ Only wealthy New Zealand residents would have been able to elect to return to England to petition for divorce there. In any case, there is no evidence of any New Zealand residents doing so.

${ }^{8}$ Matrimonial Causes Act 1857 (20 \& 21 VICT., c.85). For details of the English situation pre-1857 see S.M. Waddams. 'English Matrimonial Law on the Eve of Reform (1828-57)'. Legal History 21, no.2 (2000): 59-82; J.H. Baker. An Introduction to English Legal History, $4^{\text {th }}$ ed. London: 2002, 490-97. For a history of Scottish divorce law see Charles J. Guthrie. 'The History of Divorce in Scotland'. Scottish Historical Review 8, no.29 (1910): 39-52; Leah Leneman. Alienated Affections: The Scottish Experience of Divorce, 1684-1830. Edinburgh: 1998.
} 
be heard by that court. Prior to 1857, some English couples had taken advantage of Scotland's more liberal and accessible divorce laws, despite Scottish divorces not being valid in England. ${ }^{9}$ Over the next 16 years, almost all the Australasian colonies copied the 1857 English Act including New Zealand (see Table 1.1). The 1867 New Zealand Act allowed divorce on exactly the same grounds as the 1857 English and Welsh Act. The British government had made clear that any divorce bill which went beyond this act would not receive royal assent. ${ }^{10}$ A separate Divorce Court was not, however, established in New Zealand. Instead the Supreme Court heard divorce cases. Until 1881 three judges heard each case meaning that all cases had to be held in Wellington. In 1881 the law was amended so that cases could be heard by one judge. Wherever a Supreme Court sat, a divorce case could be heard. ${ }^{11}$

\section{Table 1.1}

Introduction of First Divorce Legislation in England, Wales and Australasia

$\begin{array}{ll}1857 & \text { England and Wales } \\ 1858 & \text { South Australia } \\ 1860 & \text { Tasmania } \\ 1861 & \text { Victoria } \\ 1863 & \text { Western Australia } \\ 1864 & \text { Queensland } \\ \mathbf{1 8 6 7} & \text { New Zealand } \\ 1873 & \text { New South Wales }\end{array}$

Source: Henry Finlay. 'Lawmaking In The Shadow of The Empire: Divorce in Colonial Australia'. Journal of Family History 24, no.1 (1999): 74-109.

While England and Wales led the way in the introduction of a divorce law, New Zealand and later the states of Australia extended the grounds for divorce much earlier than England and Wales, while maintaining the concept of 'matrimonial fault'. ${ }^{12}$ By 1950, most had legislated similar grounds for divorce, although there were some very notable exceptions. The changes that occurred in the late nineteenth and the first half of the

\footnotetext{
${ }^{9}$ For more details see Leah Leneman. 'English Marriages and Scottish Divorces in the Early Nineteenth Century'. The Journal of Legal History 17, no.3 (1996): 225-43. See also Roderick Phillips. Putting Asunder: A History of Divorce in Western Society. Cambridge: 1988, 239-40.

10 A.C. Holden. 'Divorce in the Commonwealth: A Comparative Study'. The International and Comparative Law Quarterly 20, no.1 (1971): 59.

${ }^{11}$ Divorce and Matrimonial Causes Act 1867 Amendment Act 1881 (45 VIC 1881 No. 48).

${ }^{12}$ One possible reason for divorce liberalisation being slower in England, is the greater influence of the Established Church, the Church of England (Anglican Church). Debates in the House of Lords gave the church many opportunities to voice its views with 26 Bishops holding seats in the upper house. Wade Mansell. 'The History of the Development of the Grounds for Divorce in New Zealand'. LLM thesis, Victoria University of Wellington, 1970, 111.
} 
twentieth century in these very similar societies lack any pattern - some jurisdictions introduced certain grounds significantly earlier than others, while other jurisdictions led the way in introducing one ground, but never introduced other grounds. ${ }^{13}$

In contrast to the Australasian colonies, Canada took a far more conservative approach towards reforming its divorce law. At Confederation in 1867 the federal government acquired jurisdiction over divorce. Some of the provinces already had divorce courts while in others - most notably Ontario and Quebec, the two most populous provinces of Canada - divorce was only available by an Act of the Federal Parliament. ${ }^{14}$ Across Canada divorce laws could not be changed by the provinces - only by the federal government, which was extremely reluctant to introduce any new or Canada-wide law, or even to follow the changes England and Wales made to its laws. This was because of Canada's proximity to the United States and fear that easier access to divorce would cause degeneration into an 'immoral society' like its neighbour to the south. As Sarah Carter explains, it "was considered vital to defend the "fortress" of Canadian marriage in North America against the pernicious, corrupt, and immoral influence of the United States, where it was understood that the marriage tie was loose and lax'. ${ }^{15}$ In New Zealand, Australia and England, the United States exemplified the undesirable consequences of easily available divorce but not to the same degree as was the case for Canada, and without the same impact on the law. ${ }^{16}$

Except for the procedural change in 1881, New Zealand's 1867 Act was not amended until 1898, although there were numerous attempts to change the law, by extending the

\footnotetext{
${ }^{13}$ Henry Finlay has argued that there was 'remarkable uniformity' of the development of the divorce law in the Australian colonies (his article does not consider New Zealand). See 'Lawmaking In The Shadow of The Empire: Divorce in Colonial Australia'. JFH 24, no.1 (1999): 96-105.

${ }^{14}$ Sarah Carter. The Importance of Being Monogamous. Marriage and Nation Building in Western Canada to 1915. Edmonton: 2008, 25.

${ }^{15}$ Carter, 4; See also Phillips. Putting Asunder, 465.

${ }^{16}$ While the population of Quebec was even less supportive of liberalising the divorce laws than the population of the other provinces, this does not explain why Canada did not reform its laws. The Catholic Church was strongly opposed to divorce, but so was the Anglican Church; and there was a belief that marriage was fundamental to society, not just as a private relationship but as a public institution. These ideas have been explored in depth by Nancy Cott in her 2000 study, which focuses on the United States (see, Nancy Cott. Public Vows. A History of Marriage and the Nation. Cambridge, Mass: 2000). But religious opposition and the concern with conjugal/nuclear families was present in New Zealand, Australia and England, as well as in the United States, which is why the importance of Quebec should not be overemphasized in Canada's retention of a restrictive divorce law.
} 
grounds for divorce, from $1885 .{ }^{17}$ Members of the House of Representatives and the Legislative Council who were lawyers were generally the most supportive of legal reform, with Oliver Samuel, Member of the House of Representatives (MHR) for New Plymouth (1884-1890), being the primary proponent of reform during the $1880 \mathrm{~s} .{ }^{18}$ This period coincided with the movement for women's suffrage and a growing public concern with the effects of alcohol on families and communities. Domestic violence and male drunkenness became major public concerns at this time, with the issue of domestic violence highlighted in a number of major newspapers. ${ }^{19}$ The Women's Christian Temperance Union (WCTU) supported women's suffrage, the removal of the sexual double standard from the divorce law, and highlighted the problems of violence against women and children due to drunkenness, desertion, or the failure by husbands to provide their wives with adequate finances to run the household. The WCTU thus criticised husbands' violations of the marriage contract, by failing to provide protection to their wives and children.

Margaret Sievwright, a Scottish-born feminist whose husband was a lawyer, publicised the WCTU view in a speech marking the first anniversary of the granting of women's suffrage in 1894 at Gisborne:

I am inclined, as I was at first, to be opposed to the [Divorce] Bill, but I am ashamed of the arguments of those who spoke against it. They are too puerile; too unworthy - I cannot go into them...We might perhaps have better opportunity for, and more easily obtainable, judicial separation than we have, especially when there are no children, and the present law should certainly be amended to put divorce on an equal footing for men and women. The law of Scotland knows no such inequality, and there is no more unfaithfulness among the married there than elsewhere - perhaps less. With facility of divorce, women would assuredly be again the greater sufferers. Whether any suffering could equal the present degradation of unblessed wedlock is indeed a question but would facility of divorce mend matters? It is a subject calling

\footnotetext{
${ }^{17}$ Bills were introduced in 1885, 1887, 1888, 1889, 1891, 1894 and 1895. As these were all private members' bills, they were not allocated enough time in the House and lapsed. Wade Mansell has explored these failed attempts to change the law in his LLM thesis. See also, Diane J. Laws. 'Opening the Floodgates. Changes in New Zealand Divorce Legislation, 1867-1922'. BA(Hons) research essay, University of Otago, 1980.

${ }^{18}$ Mansell, 27.

${ }^{19}$ Despite prohibition never being introduced in New Zealand, there was a strong movement which supported it from the 1890s until end of the 1920s. In 1911, 55.8 per cent of the electorate voted for prohibition, but it was not introduced as three-fifths of the electorate had to support it. For further details see Belich. Paradise Reforged. A History of the New Zealanders from the 1880s to the Year 2000. Auckland: 2001, 171; Paul Christoffel. 'Removing Temptation: New Zealand's Alcohol Restrictions, 18812005'. PhD thesis, Victoria University of Wellington, 2006.
} 
for the earnest study of both enfranchised men and women. Divorce is in the air, and might, at any moment, become a pressing question of the day. ${ }^{20}$

Sievwright's initial opposition to the liberalisation of the divorce law again demonstrates the concern feminists had that husbands might use divorce laws against their wives. The fact that husbands were twice as likely to petition for divorce as wives, prior to the reform of the law in 1898, probably encouraged such fears. ${ }^{21}$ Her claim that 'divorce is in the air' is also correct. Parliamentarians, different political organisations, the churches and newspapers discussed the question vigorously in the $1890 \mathrm{~s} .{ }^{22}$ This is in marked contrast to later changes to the divorce laws which passed with very little controversy.

In 1896 the White Ribbon, the newspaper of the WCTU, referred to those MPs who did not support removing the double standard as 'The Irresponsibles'. ${ }^{23}$ In the same year the White Ribbon carried a report from the last Convention of the WCTU which demonstrated the complexities in its position. It began by agreeing with conservatives that 'the family is the unit of the State, and any attempt to loosen family ties must be regarded as one of great gravity'. It then, however, agreed with the reformist and feminist view that, 'the law of divorce should be altered in the direction of placing women on an equal footing with men goes without saying. If the tone of morality is to be raised, there must be only one standard by which it is to be measured'. It then referred to the discussion at the WCTU convention about whether divorce should be granted 'for such causes as criminality, habitual drunkenness, continued desertion, and so on' and reported 'an overwhelming majority...decided not to ask for more than that the law should be made equal for men and women'. ${ }^{24}$ A majority of the WCTU members obviously wanted equal grounds for divorce, but feared more liberal divorce laws could result in men's

\footnotetext{
${ }^{20}$ Margaret Sievwright. 'President's Address, Gisborne Women's Political Association'. 1894. Reprinted in Charlotte Macdonald, ed. The Vote, The Pill and the Demon Drink. A History of Feminist Writing in New Zealand 1869-1993. Wellington: 1993, 49.

${ }^{21}$ Roderick Phillips. Divorce in New Zealand. A Social History. Auckland: 1981, 65-66.

${ }^{22}$ For example see, Roberta Nicholls. The Women's Parliament. The National Council of the Women of New Zealand 1896-1920. Wellington: 1996, 38-42.

23 'Divorce Bill'. WR 2, no.14 (1896), 8. Also Minutes of the Women's Convention held in the Provincial Council Chambers, Christchurch, 15 April 1896. Constitution Conference Minutes, MS-Papers-1371-106, ATL. Women's organisations petitioned parliament to remove the double standard, with seven petitions being received from women's organisation in 1895 alone. For further details see Brookes. 'A Weakness for Strong Subjects', 151.

24 'Unhappy Marriages'. WR 2, no.16 (1896): 7.
} 
responsibility in marriage being lessened by making it easier to 'dispose' of wives and children without any means of financial support. ${ }^{25}$

There was much stronger opposition to liberalisation of the divorce laws from churches. In 1894, the Auckland Anglican Diocese's Church Gazette, reported that no one supported a bill for divorce law reform that had been introduced in the house except 'an insignificant portion of the community who are chiefly conspicuous by their hostility to religion'. ${ }^{26}$ In 1895 the Presbyterian General Assembly's report on religion and morals included a clause stating if a divorce bill was introduced in the next parliamentary session, the committee would petition against it. ${ }^{27}$ The Anglican Bishop of Dunedin, Samuel Nevill, strongly criticised the divorce bill that John MacGregor, a Scottish-born lawyer and Member of the Legislative Council (1892-1899; 1914-1935), introduced later in $1895 .{ }^{28}$ In response to Nevill's criticisms, MacGregor wrote a letter to the editor of the Otago Daily Times describing Nevill as a 'latent Catholic' for promoting the idea that marriage was indissoluble and claiming that the marriage laws 'have come to have a supposititious sanctity, which renders it almost impossible to bring them into consonance with reason, common sense and morality'. ${ }^{29}$ The following year the Church Gazette made clear the Anglican position on the remarriage of divorced persons. While acknowledging there was some difference of opinion over whether the 'innocent' party to a divorce could be remarried, the editor declared, 'Personally, we would not marry any divorced person even to save our life, because we hold it is contrary to the teaching of Scripture consistently interpreted, and contrary to the canons of the Church, and is

\footnotetext{
${ }^{25}$ Patricia Grimshaw also notes that 'not a few feminists' entirely disapproved of divorce, and remarks on the 'progressive' nature of the WCTU for supporting equal divorce laws. See, Patricia Grimshaw. Women's Suffrage in New Zealand. Auckland: 1987 ed., 33. See also, Raewyn Dalziel. 'New Zealand Women's Christian Temperance Union 1885-', in Women Together. A History of Women's Organisations in New Zealand. Ngā Rōpu Wahine o te Motu, ed. Anne Else. Wellington: 1993, 72-75.The National Council of Women (NCW), many members of which were also members of the WCTU, had an equally complex view towards divorce law reform. For a history of the NCW, including its views on divorce law reform see, Dorothy Page. The National Council of Women. A Centennial History. Auckland: 1996. Also see, E. Claire Connell. 'Women in Politics, 1893-1896. A Study of Women's Organisations and Their Interest in Social and Political Reform'. BA(Hons) essay, University of Otago, 1975, 68-97.

26 'The Law of Divorce'. Church Gazette, August 1894, 148.

27 'Presbyterian Assembly'. Nelson Evening Mail, 19 February 1895. Likewise, a Committee of the Presbyterian Church of Otago opposed the divorce bill introduced in 1895. See 'Divorce Bill'. Nelson Evening Mail, 2 August 1895.

${ }^{28}$ The proposed grounds for divorce in this 1895 bill were: adultery (on equal grounds for husbands and wives) and desertion of three years or more. Divorce was also to be possible after a judicial separation had been in force for three years or more. Mansell, 60.

29 'Bishop Nevill on Divorce'. Otago Daily Times, 9 November 1895.
} 
contrary to the best interests of the human race'. ${ }^{30}$ At the Auckland Diocesan Synod in 1897, Archdeacon Willis moved that the Anglican Church 'oppose the efforts being made in Parliament from year to year to facilitate divorce, and that a commission be appointed to watch the legislation'. ${ }^{31}$ Anglicans and Catholics considered marriage to be a sacrament, and based their strong opposition to divorce on this belief. While marriage was not a sacrament in the Presbyterian and Methodist churches, neither church encouraged the reform of the divorce law, but their positions were less absolute than those of the Anglican and Catholic churches.

The Divorce Act 1898 responded to the criticisms of the sexual double standard relating to adultery, while introducing new grounds for divorce: desertion of five years or more, four years habitual drunkenness coupled with cruelty or failure to maintain in the case of husbands, or failure to perform domestic duties in the case of wives, failure to comply with a restitution of conjugal rights, and conviction for attempting to murder one's spouse. ${ }^{32}$ These additional grounds took New Zealand law substantially beyond the English and Welsh legislation in terms of making it easier to obtain a divorce and 'signalled the beginning of an era in which social legislation would have more regard to social realities and the needs of individuals than to the protection of the existing mores of society,. ${ }^{33}$ Other innovative legislation passed during the 1890 s in a period which New Zealand was considered to be a 'social laboratory', such as women's suffrage in 1893, the Industrial Conciliation and Arbitration Act 1894, and the introduction of old age pensions in 1898, enlarging the definition of citizenship to include women's political rights,

\footnotetext{
30 'Marriage of Divorced Persons'. Church Gazette, July 1896, 130-31.

31 'Auckland Anglican Synod'. EP, 6 December 1897.

${ }^{32}$ Divorce Act 1898 (62 VIC 1898 No. 42). The final ground was almost never used. It was introduced after Thomas Hall was convicted of attempting to murder his wife Kate in Timaru in 1886. (See evidence given by Justice Denniston on 1 June 1910. Minutes of Evidence. Taken Before the Royal Commission on Divorce and Matrimonial Causes. Vol II. London: 1912, 146-148). Hall was also charged with murdering his fatherin-law but the conviction was overturned on a technicality. Kate Hall petitioned for divorce in the Auckland Supreme Court in September 1901. See Kate Emily Hall v Thomas Hall, BBAE, 4984, 22/148/01, ANZ-A. For details of this case see Peter Graham. Vile Crimes. The Timaru Poisonings. Christchurch: 2007. In 1919 the required length of desertion was reduced from five years to three years. See the Divorce and Matrimonial Causes Amendment Act 1919 (10 GEO V 1919 No. 53). This Act was first introduced as a bill in the Legislative Council. Journals of the House of Representatives, Session 1919. Wellington: 1919, XLV.

${ }^{33}$ Mansell, 71.
} 
protection for the social rights of workers and the elderly, and in the case of divorce, sexual and civil rights. ${ }^{34}$

Two politicians played an important role in the divorce reform of 1898. The first was MacGregor, who was prepared to challenge the views of the churches, as demonstrated above. ${ }^{35}$ In 1897 in the Otago Daily Times he explained why the divorce law should be liberalised. 'If both spouses have shown their contempt for the obligations of marriage,' he wrote, 'and their desire to free themselves from its bondage, surely the reason is all the stronger why society should not hold them chained together; but, so far from looking at the matter in this light, the law takes care that the fetters shall be riveted on their limbs for ever'. ${ }^{36} \mathrm{He}$ also referred to the more liberal Scottish divorce law as a justification for change, showing that even though the New Zealand law was based on English divorce law, the significant number of Scots in New Zealand were aware of the law of their home country, and many supported the introduction of such a law in New Zealand. ${ }^{37}$ McGregor's ally and brother-in-law, Robert Stout (Liberal MHR for Wellington), another agnostic Scottish-born lawyer whose wife, Anna Stout, was a feminist and a member of the WCTU, initially introduced the bill. ${ }^{38}$ In 1898 , however, Stout retired from politics and did not shepherd the bill into law. MacGregor took responsibility for the bill after Stout's departure. The following year, Stout became Chief Justice, a position he held for over twenty-five years, during which time he heard many petitions for divorce.

Despite initially only supporting the removal of the sexual double standard, and opposing new grounds for divorce the White Ribbon reported the change in the law thanking Stout,

\footnotetext{
${ }^{34}$ See Philippa Mein Smith. A Concise History of New Zealand. Melbourne: 2005, 95-108; Belich, 38-46; Len Richardson. 'Parties and Political Change', in The Oxford History of New Zealand, $2^{\text {nd }}$ ed., ed. Geoffrey Rice. Auckland: 1992, 201-29.

35 G.P. Barton. 'MacGregor, John 1849/1850?-1936'. DNZB, updated 7 April 2006. URL: http://www.dnzb.govt.nz. MacGregor was known for supporting socially liberal legislation. He was responsible for introducing the Legitimation Act 1894 which allowed for children born prior to their parents' marriage to be legitimated once they married. See Chapter Seven for further details. Surprisingly none of the bills introduced by John MacGregor contained insanity as a ground for divorce, despite his brother Duncan MacGregor, a social Darwinist, doctor, inspector of lunatic asylums and inspector of hospitals and charitable institutions, being a prominent supporter of such a ground. See Margaret Tennant. 'MacGregor, Duncan, 1843-1906'. DNZB, updated 1 September 2010. URL:http://www.dnzb.govt.nz.

${ }^{36}$ John MacGregor. 'Marriage and Divorce: The Ecclesiastical and the Rationalistic Conceptions of Marriage Contrasted'. Otago Daily Times, 7 October 1897.

${ }^{37}$ An article in the White Ribbon also made reference to the Scottish divorce laws. See, 'Unhappy Marriages'. WR 2, no.16 (1896): 7. Also see Margaret Sievwright's speech from 1894 quoted above.

${ }^{38}$ Interestingly, while Stout was Premier (1884-1887) he was hesitant in his support of the 1885 bill, and he himself did not actively pursue liberalisation of the law. Mansell, 28.
} 
MacGregor and Robert McNab, Liberal Member of the House of Representatives for Mataura in Southland, for their support of the bill. ${ }^{39}$ Likewise, the Canterbury Women's Institute thanked $\mathrm{McNab}$ 'for his efforts in advancing legislation to improve the status of marriage, and congratulates him on the passage of his Divorce Bill into law'. ${ }^{40}$ Women's organisations supported the removal of the sexual double standard as they believed in one standard of morality for both men and women, and considered husbands' adultery to be just as destructive to marriages as wives' adultery. In contrast, the Anglican Church opposed the law, and after the passing of the act, reiterated its view that no bishop or priest of the church was to remarry a divorced person during the lifetime of their previous spouse. $^{41}$

Table 1.2

\section{Removal of the Sexual Double Standard from Divorce Legislation in England, Wales and Australasia}

$\begin{array}{ll}1881 & \text { New South Wales } \\ \mathbf{1 8 9 8} & \text { New Zealand } \\ 1911 & \text { Western Australia } \\ 1918 & \text { South Australia } \\ 1919 & \text { Tasmania } \\ 1922 & \text { Queensland } \\ 1923 & \text { England and Wales }\end{array}$

Source: Henry Finlay. To Have But Not To Hold. A History of Attitudes to Marriage and Divorce in Australia 1858-1975. Sydney: 2005, 52-53.

As shown in Table 1.2, New Zealand followed New South Wales in removing the sexual double standard from divorce law and the Australian states gradually followed except Victoria which delayed even after England and Wales had removed the double standard in $1923 .^{42}$ Despite being the last two Australasian colonies to pass a divorce law, New South Wales and then New Zealand became the first colonies to remove the double standard. ${ }^{43}$ It was only in 1959 when Australia passed a national divorce law that Victoria abandoned this nineteenth-century vestige.

\footnotetext{
39 'The New Divorce Law'. WR 4, no.40 (1898): 6-7. McNab had taken primary responsibility for the bill in the lower house after Stout's retirement.

40 'Canterbury Women's Institute'. Star, 9 November 1898.

41 'Re-Marriage of Divorced Persons'. Colonist, 16 March 1899.

${ }^{42}$ Matrimonial Causes Act 1923 (UK). For a history of the legal development of the divorce law in the Australian states, and later for the Commonwealth of Australia see, Henry Finlay. To Have But Not to Hold. A History of Attitudes to Marriage and Divorce in Australia 1858 - 1975. Sydney: 2005.

${ }^{43}$ For a history of divorce in nineteenth-century New South Wales see, Hilary Golder. Divorce in $19^{\text {th }}$ Century New South Wales. Kensington: 1985.
} 
Most politicians and judges at this time believed desertion was a much larger problem in the colonies than it was in Britain due to the itinerant nature of much of the male population. In contrast to its stand on adultery, Victoria pioneered the introduction of desertion as a ground for divorce in 1889 and New South Wales and New Zealand soon followed (Table 1.3). While feminist activity had focused on the removal of the double standard, in practice it was the introduction of desertion as a ground for divorce that provided the most benefits for women as evidenced in their more frequent use of desertion as a ground for divorce than adultery. In 1903, the New Zealand Tablet, a Catholic newspaper, claimed New South Wales had the third highest divorce rate in the world after the United States and Switzerland and stated the "parent State is giving bad example to Australasia'. ${ }^{44}$ In the same issue the newspaper asserted it was 'easy to go slithering down a slippery slope. And the path to divorce, like the descent of Avernus, is a smooth and easy one'. ${ }^{45}$ The article went on to warn that New Zealand was 'fast following in the evil track of legislation' of the United States. Emphasising that marriage was a sacrament, the newspaper stressed in 1906 that the 'Roman Catholic position on the question of divorce is the only true position'. ${ }^{46}$ Notwithstanding this continuing religious opposition, as this thesis will show, members of all religious denominations took advantage of the liberalisation of the divorce law to end their marriages.

Table 1.3

Introduction of Desertion as a Ground for Divorce in England, Wales and Australasia

$\begin{array}{ll}1889 & \text { Victoria } \\ 1892 & \text { New South Wales } \\ \mathbf{1 8 9 8} & \text { New Zealand } \\ 1911 & \text { Western Australia } \\ 1919 & \text { Tasmania } \\ 1922 & \text { Queensland } \\ 1928 & \text { South Australia } \\ 1937 & \text { England and Wales }\end{array}$

Source: Henry Finlay. To Have But Not To Hold. A History of Attitudes to Marriage and Divorce in Australia 1858-1975. Sydney: 2005, 52-53.

Even though there was much concern in the late nineteenth and early twentieth century with male drunkenness and its impact on women and children, in practice the grounds of

\footnotetext{
44 'Statistics of Divorce'. New Zealand Tablet, 7 May 1903.

45 ‘Our Divorce Laws'. New Zealand Tablet, 7 May 1903.

46 'Divorce'. New Zealand Tablet, 11 October 1906.
} 
drunkenness and cruelty and drunkenness and failure to maintain were little used by wives petitioning for divorce. Judges took a strong stand against such behaviour, but it was difficult for wives to prove their husbands had been guilty of four years of habitual drunkenness coupled with either cruelty or failure to maintain. In 1904 Chief Justice Stout granted a divorce to the wife of an alcoholic husband declaring, "If a man will indulge for years in drinking and when under intoxication strike and kick his wife and drive her out of the house, he has laid himself open to a divorce, and I think that it is the wife's proper remedy. It is no part of the duty of a wife to continue to be subjected to such brutal conduct. The duty of a husband is to live a sober life and to be kind to his wife'. ${ }^{47}$ Chapter Six will further explore the nature of drunkenness and its detrimental impact on marital relations.

Failure to comply with a restitution of conjugal rights was a controversial ground for divorce because in order to obtain such restitution, it was necessary to go to court and state that one honestly wanted his or her spouse to return to the marital home and for the relationship to continue. If their spouse failed to comply with this restitution, the other spouse would have grounds for divorce. In practice, petitioners often subverted the law by lying to the court saying he or she desired the return of a spouse. Once the minimum number of days had passed and the spouse had not complied with the restitution, the aggrieved husband or wife filed for a divorce. Unlike desertion cases where it was necessary to wait five years, it was possible to petition for divorce as soon as a spouse had failed to comply with a restitution of conjugal rights. In 1905 the Evening Post claimed the ground was 'one of the most vital of the causes for the increasing number of divorce decrees'. ${ }^{48}$ It was removed as a ground for divorce in 1907 but, in 1920, it again became a ground for divorce. ${ }^{49}$

This ground continued to cause disquiet after its reintroduction. As late as August 1943 the Evening Post reported the Chief Justice, Sir Michael Myers, had said in court, 'I am perfectly sure...that this restitution of conjugal rights business is all wrong. It is against all the moral welfare of the community. I have spoken about it before, as have other learned Judges; but it is of no use Judges saying anything about it; nobody takes any

\footnotetext{
${ }^{47}$ Dempsey v Dempsey, [1905] NZLR, XXIV, 830.

48 'The Rush For Divorce. Amendment in a Bill. The "Conjugal Rights" Game'. EP, 9 September 1905.

${ }^{49}$ Divorce and Matrimonial Causes Act Amendment Act 1907 (7 EDW VII 1904 No. 18); Divorce and Matrimonial Causes Amendment Act 1920 (11 GEO V 1920 No. 70).
} 
notice'. ${ }^{50}$ The article then described a case for a restitution of conjugal rights that had come before the Chief Justice where he had asked the petitioner if he really did want his wife to return to him. When the petitioner answered in the negative, he was told that this meant he would not be able to obtain a restitution. The Chief Justice allowed him to answer the question again, as he acknowledged the only difference between the petitioner and other petitioners was that he told the truth and had not been coached to give the correct answer. Eventually the law was changed in 1953 so that failure to comply with a restitution of conjugal rights was only grounds for divorce after three years (essentially making it the same as the ground of separation of three years or more). ${ }^{51}$

In 1907, after a number of earlier attempts to pass a similar law, Parliament altered the law to allow divorce in situations where one spouse had been confined to a mental institution for more than ten years and showed no sign of improvement. ${ }^{52}$ Prime Minister Joseph Ward, a Catholic, introduced the bill. ${ }^{53}$ The law included the provision, however, that the petitioner could not have caused the poor mental state of the respondent, to prevent one spouse from deliberately seeking to drive the other spouse crazy. While this ground was used infrequently, the debate surrounding the ground provoked much interest, as it was connected to the debates about eugenic policies which persisted until the 1930s. ${ }^{54}$ There was a significant concern about the 'mentally impaired' procreating and the hereditary nature of mental illness. Advocates of this ground believed it was best that the 'insane' be divorced in order to prevent them from having any more children. ${ }^{55}$

\footnotetext{
50 'Divorce Cases. Restitution Order. Chief Justice's Comment'. EP, 18 August 1943.

${ }^{51}$ Divorce and Matrimonial Causes Amendment Act 1953 (1953 No. 43).

${ }^{52}$ Divorce and Matrimonial Causes Act Amendment Act 1907 (7 EDW VII 1907 No. 78). Bills which included insanity as a ground for divorce had been introduced in 1885, 1887, 1891, 1900, 1901, 1903, 1904 and 1905. Thomas Wilford, a lawyer and Liberal MHR (Wellington Suburbs 1899-1902; Hutt 1902-1929), was the main advocate of this ground for divorce between 1900 and 1905. See, Susan Butterworth. 'Wilford, Thomas Mason, 1870-1939'. DNZB, updated 1 September 2010. URL:http://www.dnzb.govt.nz.

${ }^{53}$ Journals of the House of Representatives, Session 1907. Wellington: 1907, XLVIII. Ward's biographer, Michael Bassett, does not mention this legislation so it is unclear how Ward reconciled this action with his Catholic beliefs. The controversy surrounding the Ne Temere decree is not discussed either. See, Michael Bassett. Sir Joseph Ward. A Political Biography. Auckland: 1993.

${ }^{54}$ For further explanation of the Eugenics movement in New Zealand which grew from the 1900s and reached its height in the 1920s see Angela Wanhalla. 'To "Better the Breed of Men": Women and Eugenics in New Zealand, 1900-1935'. WHR 16, no.2 (2007): 163-82; Angela C. Wanhalla, 'Gender, Race and Colonial Identity: Women and Eugenics in New Zealand, 1918-1939'. MA thesis, University of Canterbury, 2001; Lisa Sacksen. 'The Very Error of the Moon. Dr Theodore Grant Gray and the 1928 Mental Defectives Amendment Act'. BA(Hons) research essay, Victoria University of Wellington, 2005. The Plunket Society was founded by Dr Truby King in 1907 based on his eugenic beliefs, and in 1924 the Mental Defectives Act was passed, with an amendment in 1928.

${ }^{55}$ See Catharine Coleborne. Madness in the Family. Insanity and Institutions in the Australasian Colonial World, 1860-1914. Houndmills: 2010, 54-59.
} 
Even grounds that were infrequently used still should be considered carefully when reflecting on the development of the divorce law. As Heather Brook argues, 'although certain grounds [for divorce] were infrequently cited, they nevertheless play a significant part in constituting the social meaning of marriage. Perhaps the infrequency of their transgression can be read as some indication of the depth of their significance' ${ }^{56}$ In the New Zealand context, insanity is the best example of such a ground. In 1912, the length of confinement in an institution was reduced from ten years to seven by a government bill. ${ }^{57}$ In making insanity a ground for divorce, New Zealand once again led the way in the British Empire. South Australia was the first Australian state to make it a ground in 1928; England and Wales in 1937 and Scotland in $1938{ }^{58}$ The 1907 act also introduced the conviction for attempting to murder a child of the petitioner as another ground.

Due to its innovative aspects, legal authorities in other countries interested themselves in New Zealand's divorce legislation. In 1910, Justice Denniston gave evidence to the British Royal Commission on Divorce and Matrimonial Causes which sat between 1909 and 1912. He told the Commission, 'I have never heard of any objection raised to [the law]. I think it has met with universal assent except from those conscientious persons who hold that no human law can interfere with the, what they consider, divine law on the subject. They, of course, dissent, and that is the view taken by the large Catholic community'. ${ }^{59}$ One indication that New Zealanders were relatively content with the divorce law is that no organisation or group specifically focused on altering the divorce was formed until 1963, whereas the Divorce Law Reform Union was formed in England in $1906 .^{60}$ The various churches and associated organisations, however, continued to oppose divorce imposing some restraint on legislators. ${ }^{61}$

\footnotetext{
${ }^{56}$ Heather Brook. Conjugal Rites. Marriage and Marriage-like Relationships before the Law. New York: 2007, 124.

${ }^{57}$ Divorce and Matrimonial Causes Amendment Act 1912 (3 GEO V 1912 No. 22). Mansell, 107. In 1953 the law was amended again, requiring that the respondent had been in an institution for the five years immediately preceding the filing of the petition. See, Divorce and Matrimonial Causes Amendment Act 1953 (1953 No.43).

${ }^{58}$ Phillips. Putting Asunder, 511-12.

${ }^{59}$ Minutes of Evidence taken before the Royal Commission on Divorce and Matrimonial Causes, Vol II. 1 June 1910, 147.

${ }^{60}$ Dorothy M. Stetson. A Woman's Issue. The Politics of Family Law Reform in England. Westport, Conn: 1982, 100-101.

${ }^{61}$ For example, the Mother's Union, a primarily Anglican women's organisation opposed divorce law reform. See, Elizabeth Hay. 'Association of Anglican Women 1886-', in Women Together. A History of
} 
The Divorce and Matrimonial Causes Amendment Act 1920 allowed mutual separation of three years or more, evidenced by either an oral or a written agreement, or a judicial separation, to become grounds for divorce. It was passed without much debate when the William Massey-led Reform government was in power. ${ }^{62}$ The veteran divorce law reformer, MacGregor, first introduced the bill into the Legislative Council with the support of Samuel, another persistent advocate of divorce liberalisation. ${ }^{63}$ Richard McCallum, the Liberal MHR for Wairau stated, 'If the Bill were passed it would bring happiness to very many people, and avert exposure and disgrace in many instances'. ${ }^{64}$ As late as 1950, New Zealand remained the only part of the British Commonwealth to have such a ground. Essentially this allowed for a form of no-fault divorce in a period, where technically, blame had to be established in order to gain a divorce. With the exception of the little-used ground of insanity this was the first departure in the then British Empire from the doctrine that divorce should be granted only in cases of a serious matrimonial offence. ${ }^{65}$ It was not until 1938 in South Australia that living separately or apart for five years under order from judicial separation or relief from cohabitation became a ground and in 1948 in Western Australia that living separately for five years with resumed cohabitation unlikely, became a ground for divorce. In 1959, when the federal government passed the Matrimonial Causes Act which superseded all state legislation in Australia, separation of five years or more became a ground for divorce. ${ }^{66}$ Clearly New Zealand pioneered the introduction of such a 'lenient' ground for divorce, but what is more intriguing is there was little comment on it, and almost no attempt by those not domiciled in New Zealand to take advantage of such 'easy' grounds. Legal historian Peter

Women's Organisations in New Zealand. Ngā Rōpu Wahine o te Motu, ed. Anne Else. Wellington: 1993, 165-67.

${ }^{62}$ Divorce and Matrimonial Causes Amendment Act 1920 (11 GEO V 1920 No. 70). Mansell credits the development of a 'more formal party system' by 1912 with making 'the success or failure of a Bill eminently predictable' and consequently the debates were shortened and were 'less revealing of the attitudes of individual members'. Mansell, 107.

${ }^{63}$ Journals of the House of Representatives, Session 1920. Wellington: 1920, LII. While it was not common for bills to be first introduced into the Legislative Council, particularly in the twentieth century, it was possible. (New Zealand had a bicameral legislature consisting of the elected House of Representatives and the Legislative Council, which members were appointed to, until 1950 when the Council was abolished). Samuel, after retiring from the House of Representatives in 1890, returned to politics when he was appointed to the Legislative Council in 1907 - a position he held until his death in 1925. See J.O. Wilson. New Zealand Parliamentary Record 1840-1984. Wellington: 1985.

${ }^{64}$ NZPD, 189, 6 November 1920, 731.

${ }^{65}$ J.L. Robson, ed. New Zealand. The Development of its Laws and Constitution. $2^{\text {nd }}$ ed. London: 1967, 453.

${ }^{66}$ Olive M. Stone. 'Recent Developments in Family Law in British Common Law Jurisdictions'. Columbia Law Review 67, no.7 (1967): 1246. 
Spiller has argued that in the post-World War I period the New Zealand Parliament was 'content to do nothing more adventurous than to tinker with English laws' in contrast to earlier parliaments which had taken an innovative approach to legislation and led the Empire. ${ }^{67}$ The example of this new ground for divorce, however, challenges Spiller's view and supports Cameron and Robson's views, highlighted in the introduction, of New Zealand taking an innovative approach to family law.

The lack of debate within Parliament, or within society more generally, about this new and radical ground for divorce is intriguing. Unlike the 1880s and 1890s debates, the newspapers published little public comment while the legislation was being passed and the debates in Parliament were very short, perhaps because public attention was focused on marriage law rather than divorce. ${ }^{68}$ In 1920 the Reform government passed the Marriage Act in response to the Ne Temere Papal decree of 1908 which invalidated mixed denominational marriages unless performed before a priest. ${ }^{69}$ At the time of the decree, the Presbyterian General Assembly had complained to the Prime Minister, Sir Joseph Ward. He was defeated in the 1912 election by Ulsterman and Presbyterian, William Massey. Sectarian sentiment was on the rise. ${ }^{70}$ The Marriage Act outlawed any suggestion that any couple lawfully married were not truly married. ${ }^{71}$ The passing of this law took place in the context of growing sectarianism within New Zealand with organisations like the Protestant Political Association, which was established in 1917, upsetting Catholics and resulting in acts of violence between the two groups. ${ }^{72}$ In 1920 religious groups were thus focused on the Marriage Act, and sectarian tensions made it less likely the Catholic and Anglican churches would present a united opposition to the divorce law.

\footnotetext{
${ }^{67}$ Peter Spiller et al. A New Zealand Legal History. Wellington: 1995, 116.

${ }^{68}$ Mansell, 122-124. Phillips concurs with Mansell in his 1981 work, 41-43.

${ }^{69}$ Marriage Amendment Act 1920 (11 GEO V 1920 No. 65); Miles Fairburn. 'The Farmers Take Over (1912-1930)', in The Oxford Illustrated History of New Zealand, $2^{\text {nd }}$ ed., ed. Keith Sinclair. Auckland: 1996, 192. P.S. O'Connor explains the delay between the issuing of the papal decree in 1908 and the passing of the Marriage Act in 1920 as a result of the bible in schools controversy 1911-14 and World War I. See, 'Sectarian Conflict in New Zealand, 1911-1920'. Political Science 19, no.1 (1967): 3-4. See also John Stenhouse, 'Religion and Society', in The New Oxford History of New Zealand, ed. Giselle Byrnes. Melbourne: 2009, 343.

${ }^{70}$ Allan K. Davidson and Peter J. Lineham. Transplanted Christianity: Documents Illustrating Aspects of New Zealand Church History. $3^{\text {rd }}$ ed. Palmerston North: 1995, 198.

${ }^{71}$ Fairburn, 202.

${ }^{72}$ Fairburn, 193. For further discussion of religious sectarianism in the early 1920s, see Belich, 164; Richardson, 218-19; O’Connor, 3-16.
} 
Despite their relative inattention in 1920, however, the secular and religious press did criticize the Divorce Act after it had been passed. In an editorial criticising the legislation, after its implementation in 1921, the Evening Post claimed only an hour and 35 minutes was spent discussing the bill and 'the provisions that are now causing a scandal were left practically unnoticed' ${ }^{73}$ In another editorial in January 1922 it stated, the 'Government, the Legislature and the public were all caught napping together'. ${ }^{74}$ In 1921 the Anglican Diocesan Synod of Wellington described the law as 'being more subversive of the Christian standard of marriage than any previous Act of New Zealand legislation'. ${ }^{75}$ The Methodist Church also criticised the Act, and asked that the ground of separation of three years or more be repealed as it believed it made divorces too easy to obtain and would result in 'disastrous consequences' for family life in New Zealand. ${ }^{76}$

The introduction of new grounds led to challenges and court cases testing their meaning. The most important court case to clarify the meaning of separation of three years or more was Lodder $v$ Lodder. This was heard in 1921 by Justice Salmond. In this case the husband and wife had married in 1882, separated in 1908 and negotiated a deed of separation. There were no children of the marriage and the husband petitioned for divorce in 1921, stating the cause of the original separation had been his wife's jealousy. The wife defended her husband's petition 'on the plea that the jurisdiction of the Court to grant a divorce on such a ground is discretionary, and that in the circumstance of the case a divorce should be refused' ${ }^{77}$ Justice Salmond in his judgment granting the divorce agreed with the husband in the dispute stating:

The Legislature must, I think, be taken to have intended that separation for three years is to be accepted by this Court as prima facie a good ground for divorce...In general it is not in the interests of the parties or in the interest of the public that a man and woman should remain bound together as husband and wife in law when for a lengthy period they have ceased to be such in fact...All divorce is a good thing so far as it frees the parties from an obligation which is no longer based on that mutual affection and esteem in which it had or ought to have had its origin, and restores to them the right to live their own lives and to seek happiness in the way of honour. ${ }^{78}$

\footnotetext{
73 'Hurried Legislation'. EP, 9 November 1921.

74 'Divorce Amendment'. EP, 19 January 1922.

75 'Divorce By Consent. Bishop's Forebodings'. The Times, 15 June 1921.

76 'Methodist Church. Temperance and Morals'. EP, 22 October 1921.

${ }^{77}$ Lodder $v$ Lodder (1921) NZLR, 876. For further discussion of the importance of Justice Salmond's judgment see Alex Frame. Salmond: Southern Jurist. Wellington: 1995, 221-23.

${ }^{78}$ Lodder v Lodder (1921), NZLR, 877-878. See also “"Divorce By Mutual Consent.” A New Zealand Ruling'. The Times, 29 June 1921.
} 
Perhaps, however, to reassure those who opposed liberal access to divorce, he also stated his belief that the "harmony of married life is largely due to the fact that marriage is a permanent tie which can be dissolved only for grave cause and only at the cost of public discredit to one at least of the parties' and warned of the 'possibility of public mischief' as a result of divorce, 'inasmuch as it tends to lessen the sense of responsibility with which men and women enter into marriage, and the fidelity and contentment with which they accept and obey the obligations resulting from it' ${ }^{79}$ Like the WCTU, judges also displayed an ambivalent attitude towards the liberalising of the grounds for divorce even as, in this case, they upheld the right to a legal end to marriage and the consequent right to remarry.

A subsequent case, Mason v Mason, caused controversy when Justice Herdman denied a husband a divorce when he petitioned on the ground of separation of three years or more. He had deserted his wife without just cause and she had obtained a separation order from the Magistrates' Court. His wife opposed his petition for divorce and Justice Herdman supported her in not allowing the 'guilty' party to obtain a divorce. ${ }^{80} \mathrm{Mr}$ Mason, however, took his case to the Court of Appeal which overturned Justice Herdman's decision. ${ }^{81}$ This case was widely reported and caused such outrage that Parliament passed the Divorce and Matrimonial Causes Amendment Act 1921 to counter the judicial activism of the Court of Appeal. ${ }^{82}$ The amendment allowed the court to refuse to issue a decree nisi in cases where the respondent opposed the petition, and the separation of the couple was due to the wrongful conduct of the petitioner. Parliament thus ensured the continuance of a notion of matrimonial fault despite having made divorce more accessible by the 1920 legislation. Like judges and the WCTU, parliamentarians also showed some hesitation about moving into a fully no-fault system.

\footnotetext{
${ }^{79}$ Lodder v Lodder (1921), NZLR, 877-878.

${ }^{80}$ Mason v Mason (1921) GLR, 522.

${ }^{81}$ Grant Morris. "'Salmond's Bench": The New Zealand Supreme Court Judiciary 1920-24'. Victoria University of Wellington Law Review. 38 (2007): 824.

${ }^{82}$ Divorce and Matrimonial Causes Act 1921 (12 GEO V 1921 No. 65). This Act, like the 1920 Act, was originally introduced into the Legislative Council, but this time by the Attorney-General, Sir Francis Bell. See, Journals of the House of Representatives, Session II, 1921. Wellington: 1921, XLVI. Mansell states that even Thomas Wilford, who was by 1921 the Leader of the Opposition, agreed that 'there was now an outcry in New Zealand over the recent [1920] amendments'. Mansell, 131. On the other hand Oliver Samuel and John MacGregor believed that the 1921 amendment was not required. Mansell, 138.
} 
Some churches, on the other hand, became somewhat more willing to accept the need for divorce despite their moral and spiritual scruples. By 1935 the Methodist Church had developed a complex, and somewhat contradictory view of divorce, reflecting the variety of opinions within that church and the tensions between the ideals of what marriage should be, and the reality of marriage for many people. On the one hand it claimed that marriage was indissoluble and 'could not be severed without sin' but also 'favoured the view that there should be a way out [of marriage] when the conditions of union had become intolerable. ${ }^{83}$ In 1936 the Presbyterian Church's Marriage and Divorce Committee released a report which recommended the Church recognise divorce on the ground of adultery, extreme cruelty, habitual drunkenness, insanity and desertion, but should not recognise divorce on the ground of a failure to comply with a restitution of conjugal rights or separation of three years or more. ${ }^{84}$ The following year the Presbyterian Church released 'suggested' rules for ministers which stated in the case of divorce on the ground of insanity the sane party be allowed to remarry. When a divorce was granted for separation of three years or more, or failure to comply with a restitution of conjugal rights, it was suggested neither party be allowed to remarry. More generally there was 'disapproval' of remarriage in the case of the 'guilty' party but also the 'Church recognised that in some cases there were factors making it desirable that some discretionary power be left in the hands of officiating ministers' ${ }^{85}$ As the Presbyterian and Methodists churches did not condemn divorce entirely, unlike the Anglican and Catholic churches, they became involved in a complex debate about which grounds for divorce were acceptable and which were not.

Woman Today, a feminist magazine promoting political and social issues, published an article by 'Alexa' in 1937 arguing for divorce law reform. She wrote that the Auckland Women's branch of the Labour Party sent a remit to the national conference of the Labour Party in April of that year, asking for divorce law reform. The remit requested the law be simplified and divorce made less expensive. As well, it was asked that cruelty without drunkenness become a ground for divorce, and separation for one, rather than

\footnotetext{
83 'Marriage Bond. The Christian Standpoint. Methodist Synod Discussion'. EP, 15 November 1935.

84 'Church and Divorce. Presbyterian Viewpoint'. EP, 19 November 1936.

85 'Divorce Persons. Presbyterian Rules. Remarriage Question'. EP, 10 March 1937.
} 
three, years be a ground for divorce. ${ }^{86}$ Also supportive of extending the grounds for divorce was Alfred Hanlon, who practiced law for more than fifty years in Dunedin from the 1880 s and had dealt with a large number of divorce cases. He wrote in his memoirs in 1939:

In the past I have handled scores of such cases, [non-defended divorces on the ground of separation of three or more years] and experience has convinced me that the law as it stands regarding divorce is, on the whole, wise and beneficent. It has often appeared to me, however, that the period of separation or desertion necessary to justify proceedings for divorce could safely be reduced to two years without detriment to the sanctity of the marriage tie or to society generally...I have never been able to agree that any good purpose can be served by keeping two people tied together against their will for any longer period. $^{87}$

With the exception of the 1921 amendment, the ground of separation of three years or more remained part of New Zealand's divorce law until 1980 when irreconcilable differences as evidenced by two years separation became the only ground for dissolution. New Zealand was comparatively late in introducing 'no fault' divorce in 1980, but this can be explained, in part, by the existence of a ground that in practice functioned very similarly to irreconcilable differences. Essentially Hanlon was advocating a ground identical to that introduced in 1980 , over forty years earlier, albeit mildly within his memoirs.

In 1953, living apart for seven years or more with little chance of reconciliation became a ground for divorce in the Divorce and Matrimonial Causes Amendment Act. ${ }^{88}$ This was the last major amendment to the grounds for divorce during the period covered by this study. The 1953 amendment was a government bill introduced by Attorney-General Clifton Webb in the Sidney Holland-led National government. Due to the existence of the ground of separation of three years or more, this new ground was used infrequently, and

\footnotetext{
86 'Alexa'. 'Women and Divorce Reform - An Opportunity for Feminists'. 1937. Reprinted in Charlotte Macdonald, ed. The Vote, The Pill and the Demon Drink. A History of Feminist Writing in New Zealand 1869-1993. Wellington: 1993, 115-16.

${ }^{87}$ A.C. Hanlon. Random Recollections. Notes on a Lifetime at the Bar. Dunedin: 1939, 306.

${ }^{88}$ Divorce and Matrimonial Causes Amendment Act 1953 (1953 No. 43). For more details see 'Divorce: Seven Years' Separation'. NZLJ XXXI, no.21, (1955): 321-23.
} 
Phillips regards the act as 'an essentially conservative measure' ${ }^{89}$ As the debates on this bill were brief, it is difficult to understand what provoked its introduction. ${ }^{90}$

While the grounds for divorce changed in New Zealand between 1898 and 1953, the procedure for obtaining a divorce stayed much the same. One spouse, the petitioner, asked the court to grant a divorce on the basis of one or more of the available legal grounds. The petition was served on the respondent who could counter-petition, appoint a lawyer to represent him or her in court if he or she wished to challenge the petition, or, as many did, do nothing. The Supreme Court sat quarterly in each judicial district. The case would be heard in the Supreme Court, normally before a judge alone, but sometimes before a jury as well, and then if the divorce was to be granted, a decree nisi would be issued. ${ }^{91}$ After at least three months had passed (prior to 1898 , it was necessary to wait at least six months) either the petitioner or the respondent could apply to the court to have a decree absolute issued allowing either one of the couple to remarry. A re-marriage that occurred prior to the issuing of the decree absolute was considered bigamous. Despite this, many people thought that they were divorced after only having a decree nisi issued, and then subsequently remarried, and unknowingly committed bigamy. ${ }^{92}$

Most cases were heard by a judge alone. The general rule was that undefended cases were heard by a judge alone, and defended cases were heard before a jury. An application could be made, however, for defended cases to be heard before a judge alone. In 1925 the rule was altered so that defended adultery cases were heard before a judge and jury and all other cases were heard by a judge alone. ${ }^{93}$ Judges had the power to hear cases in

\footnotetext{
${ }^{89}$ Phillips. Divorce in New Zealand, 45. Following the 1921 amendment, respondents could oppose a petition for divorce if the petitioner's behaviour was responsible for the separation. The ground of living apart for seven years or more included no such provision and also allowed for a divorce where no explicit agreement to separate had been made.

${ }^{90}$ For the debate which occurred during the second reading of the bill see, NZPD, 299, 28 August 1953, 812-24.

${ }^{91}$ Some cases were heard very quickly. For example Truth reported in 1919 that a decree nisi was issued by a judge after hearing the details of the case for only three minutes and fifty seconds. 'A Deluge of Divorce'. NZT, 7 June 1919.

${ }^{92}$ For example, in August 1943 the Labour MHR for Wellington West, Catherine Stewart, introduced a bill into parliament to dissolve the marriage of Ida and Percy Morris as from 24 December 1912, and to validate the marriage of Percy Morris and Victoria Ramsay. This was to resolve the problem created when Percy Morris had obtained a decree nisi, but not a decree absolute to dissolve his first marriage. He married Victoria Ramsay, and later died in an accident in February 1936. His 'widow' was unable to sue for damages as they were not lawfully married. Undoubtedly, many other people made the same mistake, but often no one ever realised, so it did not cause a problem. See 'Unusual Bill. Validating a Divorce'. Compensation Rights'. EP, 26 August 1943.

${ }^{93}$ W.J. Sim. 'The New Divorce Rules'. NZLJ, 7 September 1943, 189.
} 
chambers, although they rarely exercised this right. The issue of privacy and exposure in divorce cases is further explored in Chapter Five. The Solicitor-General had the power to intervene in cases where he believed there had been a miscarriage of justice or some form of connivance, but in practice this was unusual. ${ }^{94}$

Female petitioners and respondents had to navigate a male-controlled divorce system in which all the judges were men. ${ }^{95}$ There were very few women lawyers. ${ }^{96}$ For example, there was not one woman lawyer in the cases sampled from the Wellington Supreme Court. Until 1942 women were not able to serve on juries, and even then they had to notify officials in writing that they wished to serve on juries in order for their name to be added to a list of potential jurors. ${ }^{97}$ By 1959 only two women had served on juries. ${ }^{98}$ Only women between the ages of 25 and 60 were permitted to apply to be jurors, whereas Pakeha men between the ages of 21 and 60 were eligible for jury service. ${ }^{99}$ It was not until 1963 that women were included on the roll in the same way as men, and even then, they had an 'absolute right' to have their names withdrawn on request. ${ }^{100}$ Feminists saw this situation as disadvantaging women, and from 1896 the National Council of Women had been campaigning, albeit unsuccessfully, for women to be admitted to jury service. ${ }^{101}$

In all cases where husbands petitioned for divorce on the ground of adultery it was necessary to name the man with whom their wife had committed adultery, as a corespondent in the case. Such co-respondents were served with papers and were entitled to be represented in court by a solicitor. If it was found that he had committed adultery then

\footnotetext{
${ }^{94}$ Examples where the Solicitor-General did intervene include: Jobson v Jobson, [1910], NZLR, 48-56; Hopkins v Hopkins, [1933], NZLR, 1486-1493; Donaldson-Edward v Donaldson-Edward, [1936], NZLR, 342-346; Latimer v Latimer and Another, [1947], NZLR, 40-41.

${ }^{95}$ The first woman, Silvia Cartwright, was not appointed to the High Court (the Supreme Court's name was changed to the High Court in 1979) until 1993, although by this time divorce cases were heard in the Family Court.

${ }^{96}$ For a history of women in the legal profession in New Zealand, and the difficulties women had finding work as qualified lawyers see, Gill Gatfield. Without Prejudice. Women in the Law. Wellington: 1996, 4456. She also explains how women lawyers were discouraged from attending court where 'vice and violence were openly paraded'. Gatfield, 73-74.

${ }^{97}$ Women Jurors Act 1942 (6 GEO VI 1942 No.12).

${ }^{98}$ Sandra Coney, 'Good Women and True...' in Standing in the Sunshine. A History of New Zealand Women since they Won the Vote, ed. Sandra Coney. Auckland: 1993, 40.

${ }^{99}$ It was only in 1962 that Maori were placed on an equal footing to Pakeha regarding jury service. See, Juries Amendment Act 1962 (1962 No. 35).

${ }^{100}$ Cameron. See also, Juries Amendment Act 1963 (1963 No. 141). In 1976 jury service finally became equal under the Juries Amendment Act 1976 (1976 No. 48).

${ }^{101}$ Page. The National Council of Women, especially 65-66. Page highlights that British women were admitted to jury service from 1919, demonstrating that while New Zealand was ahead of Britain in some areas of legal emancipation for women, in other areas it lagged far behind.
} 
he could be ordered to pay costs and sometimes damages as well. This issue is explored in more detail in Chapter Four. When wives petitioned for divorce on the ground of their husband's adultery they were supposed to name the woman with whom their husband had committed adultery, if they knew her name, but she was not made a co-respondent in the case. This meant that she was not served with papers, and some women were not aware that their names had been mentioned in a case until they read about it in the newspapers. It was only in 1943 that women who were named as adulteresses in divorce cases had to be informed - but they were not actually named as co-respondents and could not be made to pay costs or damages. ${ }^{102}$ This was because the husband was assumed to be entitled to compensation for loss of access to his wife's labour and body; wives were not thought to be entitled to such compensation. As well, it was supposed women would not have the money to pay costs and damages.

Financial resources played an important role in determining access to divorce. Throughout the study period there was no government funded legal aid system for those who sought a divorce. It was possible to petition in forma pauperis, but few people did as it was extremely difficult to qualify for this support. Organisations, such as the Society for the Protection of Women and Children (SPWC), arranged legal representation for women whom they were assisting. Normally lawyers would volunteer to assist the SPWC with their cases. One such lawyer was Ethel Benjamin, the first woman to obtain a law degree in New Zealand. She practised in Dunedin and her first course of action, when faced with a marital dispute, was normally to threaten legal action if a husband refused to change his drunken and abusive behaviour. If this failed she petitioned for divorce or separation. Benjamin's biographer Janet November claims, '[s]eparation was preferred because it was an easier and a much less public process in a moralistic and judgemental age'. ${ }^{103}$ Benjamin became known as a lawyer who specialised in judicial separation and divorce cases and a number of women unconnected with the SPWC sought her representation. ${ }^{104}$

\footnotetext{
${ }^{102}$ W.J. Sim. 'The New Divorce Rules'. NZLJ, 7 September 1943, 190.

${ }^{103}$ Janet November. In the Footsteps of Ethel Benjamin. New Zealand's First Woman Lawyer. Wellington: 2009, 78-79. Separation orders were issued by the Magistrates' Court making the process cheaper and quicker than petitioning the Supreme Court for a judicial separation or a divorce.

${ }^{104}$ Carol Brown. 'Ethel Benjamin: New Zealand's First Woman Lawyer'. BA(Hons) research essay, University of Otago, 1985, 53-65.
} 
In 1939 a Legal Aid Act, which applied to civil cases, was passed but was not implemented due to the outbreak of World War II. ${ }^{105}$ The Law Society, however, promised the government it 'would ensure that no one with a good case was prevented from proceeding with it because of lack of money' although Robson suggested in 1967, '[i]t may not unfairly be suggested that this arrangement has worked tolerably only because it is little known and little used'. ${ }^{106}$ It was only in the late 1960s that the government considered introducing a more formal scheme to provide civil legal aid, and so throughout the period under study there was no guaranteed form of financial support for litigants. ${ }^{107}$

For Maori, the divorce law was not always straightforward. Until 1911 Maori were exempt from registering their marriages, although they could if they so wished. ${ }^{108}$ If they did register their marriage, then they were covered by the same divorce laws as Pakeha New Zealanders; if they did not register their marriages, they did not need to get a divorce from the courts. There were a number of cases where the validity of a marriage between two Maori was debated in relation to a divorce suit. ${ }^{109}$ Joan Sangster has argued 'while colonialism has many faces, its dynamic often includes attempts to redefine the sexual codes and family relations of indigenous populations'. ${ }^{110}$ Maori were certainly encouraged to conform to the western form of marriage and this 'encouragement' also increased with the growth of the welfare state and the increasing number of financial benefits attached to being married.

The law relating to Maori customary marriage was often confusing, leading to uncertainty over whether the marriage had been legally registered or not. The primary problem was the uncertainty over who was considered to be Maori under the law, and who was not. This was relevant as far as obtaining a divorce was concerned, as if the requirements for a

\footnotetext{
${ }^{105}$ Legal Aid Act 1939 (3 GEO VI 1939 No. 42).

${ }^{106}$ Robson, 108. Legal Aid was introduced in Britain by the Labour government in 1948, making the divorce court far more accessible to those on low incomes. See Pat Thane. "Family Life and "Normality" in Post-War British Culture', in Life After Death. Approaches to a Cultural and Social History of Europe during the 1940s and 1950s, eds. Richard Bessel and Dirk Schumann. Cambridge: 2003, 198.

${ }^{107}$ The costs associated with divorce are explored in further detail in Chapter Four.

108 Angela C. Wanhalla. 'Transgressing Boundaries: A History of the Mixed Descent Families of Maitapapa, Taieri, 1830-1940'. PhD thesis, University of Canterbury, 2004, 131-32; Durie-Hall, 186.

${ }^{109}$ Rogers v Rogers and Another, [1899], NZLR, 115-116; Matiu v Reweti and Another, [1906], NZLR, 287288; Matiu v Monika Reweti and Another, [1907], NZLR, 64-644; Renata Te Ni v Tuihata Te Awhi and Rotia Hini, [1921], NZLR, 729-731.

${ }^{110}$ Joan Sangster. Regulating Girls and Women. Sexuality, Family, and the Law in Ontario, 1920-1960. Don Mills: 2001, 171.
} 
customary marriage had not been fulfilled, then there was no binding marriage, and it was not necessary, and was in fact impossible, to obtain a divorce. The major confusion was over whether 'half-castes' were entitled to be married under customary law. This issue was finally resolved in 1921 in a Supreme Court decision in the case Parker v Parker. Justice Salmond found 'the privilege of informal marriage formerly conferred on persons of the Native race by the Marriage Act, 1880, the Marriage Act, 1904, and the Marriage Act, 1908, extended to all persons of Maori descent, whether pure or mixed'. He went on to explain, 'a person of mixed descent - partly Maori and partly English - belongs in truth and fact both to the Maori and the English race. He [sic] is entitled, therefore, in right of his Maori blood to the statutory privilege conferred upon members of the Maori race'. 111

Assuming the validity of the marriage went unchallenged, another way in which a divorce involving Maori was different was if the respondent or the co-respondent was Maori, and this included 'half-castes', the petition had to be served accompanied with a Maori translation, regardless of their ability to understand English, or even their ability to understand Maori. It is unclear when this was no longer a requirement, but certainly into the 1940s petitions were being translated, ${ }^{112}$ although cases involving Maori when petitions were not translated, have been located, and this went unchallenged. ${ }^{113}$ In 1914 one petitioner asked the Court to ignore the rule requiring the translation of the petition if he was able to show by affidavit that the respondent and co-respondent could understand English. The Judge found that the Court should not allow such a waiver 'especially in a divorce suit... The terms of the rule requiring service of a translation are mandatory, the object of the rule being that persons of the Native race shall have in their own language the fullest information furnished to them of the proceedings'. ${ }^{114}$

One way to undermine the institution of marriage was to ascribe no significance to it. For example, in March 1934 at the Ngaruawahia Registry Office Martin C. married a Maori woman, Lucy K. Ten years later he petitioned for a divorce on the ground of her desertion on the day of the marriage - they had never lived together as Lucy had refused to live with him, 'on the account of this religion'. This religious dispute is not elaborated upon,

\footnotetext{
${ }^{111}$ Parker v Parker, [1921], NZLR, 733.

112 See for example, $G v G \& H$, AAOM/W3265/D1109/1943/ANZ-W.

${ }^{113}$ Asher v Asher \& Elliott, AAOM/W3265/D3820/1931/ ANZ-W.

${ }^{114}$ Adlam v Adlam \& Palmer, [1914], NZLR, 1018.
} 
but a difference in religious outlook may explain why the couple had chosen a civil ceremony. A law firm in Hamilton was contacted by the petitioner's lawyers in Wellington to assist with locating Lucy. In a letter on 8 June 1945 the Hamilton lawyers wrote, they had,

traced a Mrs Sylvia C[...] who was working at a Chinese laundry in Hood Street, Hamilton, who was alleged to be the mother of the respondent. Mrs $\mathrm{C}[\ldots]$ is a native woman separated from her husband. Mr King asked her if she was the mother of Lucy C[...] who was married to Martin C[...] in 1934. She admitted that she was the Respondent's mother, and in answer to Mr King she admitted that the parties did not live together after the marriage ceremony. She stated her daughter was living in Te Kowhai as Mrs T[...].

Mr King explained that as the marriage had been current for ten years, and during the whole period the parties had not lived together, and there was no possibility of the marriage being a useful one, it was in the interests of both parties that the marriage should be dissolved, and he asked Mrs C $[\ldots]$ to assist with her evidence. She agreed accordingly.

Mr King then reported on the 22nd September 1944 to Messrs. Young \& Callaghan, and again saw Mrs C[...] on the 20th October as to her evidence. In the meantime we think that the Chinaman, her employer, had discussed the matter with her, and Mr King was greeted with the suggestion that she would want $£ 10$ to go to Wellington, and all expenses paid. When it was suggested that she might be subpoenaed, she stated she would not then assist with her evidence. Mr King pointed out it was in her daughter's interests that she should be clear of a marriage which had utterly broken down, and her reply was that "the Maori did not worry, did not care."

We accordingly advised that a Subpoena should be issued or that her evidence should be taken on Affidavit.

Our next enquiries were made on the 6th December 1944 when our clerk, Miss Laxon, attended on several occasions she was told that Mrs C $[\ldots]$ had left, and the Chinaman had no idea when she would return, if at all. ${ }^{115}$

There is no evidence of Mrs C. going to Wellington for the case, but, regardless, Martin C. did secure a divorce in 1945, although Mrs C'.s non-cooperation would have made this more difficult for him. Other than revealing some strong racial stereotypes of Chinese as cunning and money hungry, as well as nameless, and the idea that an elderly Maori woman would be too naïve to think to ask for money on her own, this case also shows how the power of marriage, in part, relies on individuals believing in its significance. Lucy was able to ignore her legal marriage and form another marriage-like relationship, because she remained living in a Maori community and had the support of her whanau. Had she been living in an urban area she would have been more likely to have been subjected to varying forms of state surveillance, whether it had been through access to the

${ }^{115} C v C$, AAOM/W3265/D1737/1944/ANZ-W. 
benefits of the social welfare state and the need to prove that her relationship was legally sanctioned or through much more coercive state powers. ${ }^{116}$

Not all Maori communities, however, were supportive of extramarital relationships or divorce. When Whina Cooper (then Whina Gilbert) announced her intention to marry William Cooper in 1935 at a hui, the community reacted with 'shock and anger'. Her behaviour challenged the customs of a Maori rural community and the Catholic Church, of which she was a member. The couple relocated to Kamo, near Whangarei, where they had four children, and eventually married in 1941 after Cooper's divorce was granted. ${ }^{117}$ The differences between these two situations show there was not one Maori view of divorce, and that reactions depended on iwi affiliations, the rank of the individuals involved, and the religious associations of the individuals. ${ }^{118}$

By the early 1950s there were no legal differences between Maori marriages and those of the Pakeha population. All difference had been eliminated by the Maori Purposes Act 1951 and the Marriage Act $1955 .{ }^{119}$ Donna Durie-Hall makes clear that many Maori resented this legislation as it denied the legality of tikanga Maori. She explained: 'Social workers pressured many Maori couples with children into contracting legal marriages in order to ensure the legitimacy of the offspring and their access to the Family Benefit. At the same time the Act made both the establishment and dissolution of legal marriages difficult and costly'. ${ }^{120}$ While Maori, in theory, could have chosen not to register their marriages and therefore would not have needed to seek a divorce if the situation arose, the

\footnotetext{
${ }^{116}$ Beverly Schwartzberg has noted in her study of desertion and bigamy in late-nineteenth century America that once the federal government began providing pensions, firstly to Civil War veterans and their widows, the government took a much stronger interest in men with multiple wives. See, "'Lots of Them Did That": Desertion, Bigamy, and Marital Fluidity in Late-Nineteenth-Century America'. JSH 37, no.3 (2004): 573600 .

117 Michael King. 'Cooper, Whina 1895-1994'. DNZB, updated 1 September 2010. URL: http://www.dnzb.govt.nz; Steven Oliver. 'Cooper, William Turakiuta 1885/1886?-1949'. DNZB, updated 1 September 2010. URL: http://www.dnzb.govt.nz. See also, Michael King. Whina. A Biography of Whina Cooper. Auckland: 1991 ed, 134-38. King explains how Whina tried to negotiate her own arrangement with William's first wife, Maggie. Whina asked Maggie, 'I'd like your husband to be my husband too. I know it's a hard thing to ask, but would you let him be my husband too?', 136.

${ }^{118}$ Another example is Makereti Papakura, who was a prominent Te Arawa woman of rank who divorced twice - first in New Zealand in 1899 and then in England in 1923. Her biographer, Paul Diamond, does not note any criticism of her for this and she held a number of important roles in New Zealand after her first divorce. See, Paul Diamond. Makereti. Taking Maori to the World. Auckland, 2007.

${ }^{119}$ Maori Purposes Act 1951 (1951 No. 75); Marriage Act 1955 (1955 No. 92); Donna M Tai Tokerau Durie-Hall. 'Maori Marriage. Traditional Marriages and the Impact of Pakeha Customs and the Law'. In Standing in the Sunshine. A History of New Zealand Women since they Won the Vote, edited by Sandra Coney. Auckland: 1993, 186.

${ }^{120}$ Durie-Hall, 186.
} 
financial benefits offered by the welfare state required conformity with the state system of the registration and regulation of marriages, and to live in 'irregular' unions often meant missing out on such benefits.

Women continued to face legal and practical disadvantages when it came to obtaining a divorce. The most obvious of these disadvantages was the issue of domicile. New Zealand had inherited the British view of domicile, which was that a wife always shared her husband's domicile. ${ }^{121}$ This was a problem when it came to petitioning for divorce as one had to petition for a divorce in the jurisdiction where one was domiciled. It was particularly difficult in cases where husbands had deserted their wives, and their wives no longer knew where they were, as it meant that not only were there a number of wives who did not live in the country or state in which they were legally domiciled, some did not what their legal domicile was. To ease the problem, New Zealand and the Australian states introduced clauses into their divorce legislation that allowed for women to retain their domicile. Not only did this make it easier for women to petition for divorce, but a husband's move to a jurisdiction with a stricter divorce law did not disadvantage the wife. ${ }^{122}$ This only applied, however, if the woman remained in the area where she had previously been domiciled with her husband. The only change to this legislation was in New Zealand in 1930 when the law was amended to allow that wives who had been living in New Zealand for three years prior to filing a petition, and intended to reside in New Zealand permanently, would be considered domiciled in New Zealand. ${ }^{123}$ This gave wives the domicile which would apply if they were single. ${ }^{124}$ Given the greater mobility of New Zealanders and Australians in comparison to the British, there was more need to make provision for husbands and wives living in different jurisdictions, and perhaps an enhanced awareness of the inequity of not doing so. Moreover, there was a perception that desertion was a bigger problem in the antipodes and this is why the legislatures in

\footnotetext{
${ }^{121}$ Erwin N. Griswold. 'Divorce Jurisdiction and Recognition of Divorce Decrees: A Comparative Study'. Harvard Law Review 65 no.2 (1951): 196. Also see Gladys L. Schwatka. 'Recognition of Foreign Country Divorces: Is Domicile Really Necessary?’ California Law Review 40, no.1 (1952): 93-103.

${ }^{122}$ The New Zealand Divorce Act 1898 read, 'A deserted wife who was domiciled in New Zealand at the time of desertion shall be deemed, for the purposes of this Act, to have retained her New Zealand domicile, notwithstanding that her husband may have since the desertion acquired any foreign domicile'. Divorce Act 1898 (62 VIC 1898 No. 42). In 1928 the provision was extended to wives where the parties were separated either under an agreement (which might be oral) or under a decree of judicial separation. Divorce and Matrimonial Causes Act 1928 (19 GEO V 1928 No. 16) .

${ }^{123}$ Divorce and Matrimonial Causes Amendment Act 1930 (21 GEO V 1930 No. 43).

${ }^{124}$ Griswold, 207.
} 
New Zealand and the various Australian states were more prepared to rectify the problem, than the British parliament.

World War II gave even greater impetus to challenges to the assumption that husbands and wives shared the same domicile, as couples might be married and have never lived together in a specific jurisdiction. Britain adjusted to this situation with the Matrimonial Causes (War Marriages) Act of 1944. Australia followed in 1945 with its own Matrimonial Causes Act which also dealt with the problem of movement between the different states of Australia by effectively removing the domicile requirement. ${ }^{125} \mathrm{New}$ Zealand followed suit in $1947 .{ }^{126}$ In this aspect of divorce law, all three societies allowed greater deviations from the concept of marital unity than had been previously embedded in British law. Most importantly, for much of this period women who married foreigners lost their British nationality on marriage, and for those women who subsequently divorced their alien husbands, they did not necessarily regain their nationality as of right.

Unlike domicile, the issue of marital unity with regard to nationality is a relatively recent creation. It was only in 1870 that British law was altered so a British woman who married a foreigner lost her British nationality, and conversely a foreign woman who married a British man gained British nationality. ${ }^{127}$ Until 1948 there was no separate form of nationality for the Dominions, and so Britain was particularly keen for there to be uniformity amongst laws relating to nationality. The issue was often discussed at imperial conferences during the inter-war period, as well as at the League of Nations and other worldwide conferences. Women's nationality became an issue in the interwar period primarily because of the treatment of British-born women married to Germans during World War I, and also because in 1922 the United States changed its law, so that foreign women who married American men did not automatically gain American nationality - it was necessary for them to reside in the United States for a year first. ${ }^{128}$ This meant that a British woman who married an American outside of the United States became stateless upon marriage. $^{129}$

\footnotetext{
${ }^{125}$ Ibid., 204-5.

${ }^{126}$ Matrimonial Causes (War Marriages) Act 1947 (11 GEO VI 1947 No. 8).

${ }^{127}$ Dorothy Page. 'Women and Nationality. Feminist Organisations in the Inter-War Period', in Women in History. Essays on European Women in New Zealand, eds. Barbara Brookes, et al. Wellington: 1986, 161.

${ }^{128}$ For further details of concerns regarding British women who were married to Germans and vice-versa see, Susan R. Grayzel. Women and the First World War. London: 2002, 67-69.

${ }^{129}$ Page, 'Women and Nationality', 167.
} 
Issues of nationality were particularly a problem for women who divorced; for while the loss of nationality on marriage to a foreigner was automatic, it was not automatic that they re-gained their nationality if they divorced. ${ }^{130}$ At several imperial conferences New Zealand was active in having the issue of married women's nationality placed on the agenda. After the Hague Convention, in 1930, it was decided that women who did not gain their husband's nationality at marriage should be able to retain their own nationality rather than becoming stateless. This was enacted into British law in 1933, but it did not cover women who divorced. ${ }^{131}$ New Zealand decided to act alone in 1934 by changing the law to allow New Zealand born women married to foreigners to retain their British nationality so long as they remained in New Zealand. ${ }^{132}$ This proviso was added because the British government wanted imperial uniformity. ${ }^{133}$

In an attempt to clarify the situation regarding divorced women regaining their British nationality, the British Foreign Office issued a circular, in 1934, stating:

that the question of the readmission to British nationality of British-born women who have become aliens by reason of marriage and whose husbands have died or whose marriage has been dissolved, has recently been under consideration....applications for naturalisation were formerly not entertained unless or until the woman returned to the United Kingdom with the intention of residing permanently therein or elsewhere in His Majesty's dominions. The Secretary of State for the Home Department is, however, now prepared to entertain applications from women in this category even when the applicant is resident abroad, provided that she does not possess the nationality of the country in which she resided. ${ }^{134}$

This shows that for some time, British-born divorced women were able to reapply for British citizenship, but its granting was not automatic nor was the process straightforward. The situation was resolved in 1948 when the Home Secretary announced that the Commonwealth Governments had agreed that British women married to foreigners should retain their British nationality unless they took active steps to renounce it.

\footnotetext{
${ }^{130}$ For example, see the situation of Miriam Soljak. See, Yvonne Van Dongen. 'New Zealand-born, but “Alien”. The Fight of Miriam Soljak', in Standing in the Sunshine. A History of New Zealand Women since they Won the Vote, ed. Sandra Coney. Auckland: 1993, 131.

${ }_{131}$ Page, 'Women and Nationality', 173.

132 British Nationality and Status of Aliens (in New Zealand) Amendment Act 1934 (25 GEO V 1934 No. 38).

${ }^{133}$ Page, 'Women and Nationality', 174. For further details of the Hague Conference see Dorothy P. Page. "“A Married Woman, or a Minor, Lunatic or Idiot." The Struggle of British Women against Disability in Nationality, 1914-1933'. PhD thesis, University of Otago, 1984, 182-231.

${ }^{134}$ Foreign Office Circular, 23 November 1934, DO35/132/4562/NA(UK).
} 
Furthermore, foreign women would not in future automatically acquire British nationality on marrying a British subject, but would have the right to apply for it, the granting or refusal of such application being in the hands of the Minister concerned'. ${ }^{135}$ At the same time separate dominion nationality was created, giving New Zealand and Australia more freedom to legislate on matters of citizenship and nationality.

Another Royal Commission on Marriage and Divorce sat in Britain between 1951 and 1955. Wilfred E. Leicester, a Wellington solicitor and Justice Finlay were the two New Zealanders who gave evidence to the Commission. Both spoke primarily about the ground of separation of three years or more, presumably because New Zealand was the only country in the British Empire providing such a ground, and it was the ground most frequently used in divorce petitions. Wilfred Leicester explained:

Of all the parts of the British Empire, New Zealand has, I think, the most liberal divorce laws, and this may be due to the fact that we are a primary producing country and expansive legislation has not been the least of our primary products. In much of this legislation we have striven to remedy grievances rather than to achieve theoretical perfection. In the past seventy years, various Ministries have tended to regard New Zealand as the world's social laboratory, and the search for policies of broad humanitarianism, backed up by fifty years of women's franchise and women's organisations of an astonishing number and variety, and to be found in every part of the Dominion, has resulted in the gradual widening of the grounds for divorce. In so far as public morality, in relation to divorce, has been discussed during this legislative process, emphasis has been laid upon the immorality that results, not from the making of divorce easier, but from the retaining of the shadow of marriage where the substance has ceased to exist. Sociologically, at least so far as New Zealand is concerned, there is no proof that the liberality of our ideas in divorce has brought about anything but good. ${ }^{136}$

Leicester voiced a pragmatic and humanitarian view towards divorce, and situated divorce law reform in the context of the growing legal recognition of women rights. He articulated the view that restrictive divorce laws do not stop marriages ending, they only prevent people from forming newly legally sanctioned relationships. Justice Finlay gave his evidence about three months later, and had a different perspective on the New Zealand situation. Addressing the English commissioners he said:

But it seems to me that you must start on the basis that we are the same people. We started on the same footing, and if I may say so - I do not want to appear to be advocating a cause or being sentimental about it - we have dealt

\footnotetext{
135 "Nationality of Married Women." Wife and Citizen, (September, 1946), n.p., 5MWA/4/1/WL.

${ }^{136}$ Minutes of Evidence taken before the Royal Commission on Marriage and Divorce. 22 April 1953, 952. See also, 'Divorce in New Zealand'. The Times, 31 March 1953.
} 
with the question of divorce throughout our history in exactly the same spirit. We have exactly the same deep respect for the sanctity of the home and the sanctity of the marriage tie that you have. Here and there we have taken a step forward, always feeling, I imagine - I can only speak as I read the mind of the legislators - that we were taking a step that was for the public good and consonant with the public conscience - I imagine that the same purpose has actuated the English legislators. Those features do not seem to appear in $\mathrm{Mr}$ Leicester's evidence at any point, and they to me make a very great difference. $^{137}$

He then went on to claim that New Zealanders, 'as a people, [are] more Victorian, I think, than you are in England. We are much more inclined to reflect the conservative outlook than the progressive. That is my sincere belief after a lifetime in the country' ${ }^{138}$ Clearly both men believed the divorce laws and the number of divorces in New Zealand reflected New Zealand society more generally, whether that be a liberal, social laboratory or a Victorian, conservative society. The 1898 Act was a product of the Liberal government which had established a pattern of passing socially innovative legislation. On the other hand, the most radical legislation that was passed in 1920 was in large part a result of most politicians paying little attention to the implications of such legislation. In relation to divorce law, it would be fair to describe New Zealand as liberal, albeit not intentionally. Pragmatic may be the best term to use, as even after the implications of the 1920 Act were realised and an amendment was passed to restrain its impact, most divorces were granted on the ground of three years separation or more, and there were no further attempts by successive governments to remove or further restrict the implication of this ground.

In summary, the legal framework for divorce in New Zealand began with the 1867 Act and was significantly amended in 1898. The administration of the law was the responsibility of the courts, specifically the Supreme Court and it was to that court people seeking legal dissolution turned. Subsequent chapters show how the law was used and operated 'on the ground' by people. The introduction of insanity as a ground for divorce in 1907 was the first challenge to the concept that one spouse had to be at fault in order to obtain a divorce. The more significant challenge to the concept of matrimonial fault occurred in 1920 with the introduction of separation of three years or more as a ground for divorce. As subsequent chapters show, this ground quickly became the most common

\footnotetext{
${ }^{137}$ Minutes of Evidence taken before the Royal Commission on Marriage and Divorce. 14 July 1953, 963.

${ }^{138}$ Ibid., 965.
} 
ground for divorce, and was the least acrimonious. This legislation, as the rest of the thesis will demonstrate, set the trend for divorce legislation making access to divorce not only more available, but also making divorce more innocuous and less likely to make the divorcing couple an object of scandal. 


\section{Chapter Two}

\section{Major Trends in Divorce and Divorcing Couples}

From the passing of the Divorce Act in 1898, until the end of the 1950s, the number of divorce petitions lodged, the number of divorces granted and the divorce rate increased substantially. This chapter examines the trends in the incidence of divorce and key characteristics of the divorcing population during the first half of the twentieth century in New Zealand. ${ }^{1}$ Petitions for divorce as well as decrees absolute increased in both absolute numbers and proportionally between 1898 and 1947, the year the Wellington Divorce Database concludes. Wives' petitions for divorce more often succeeded than husbands' efforts throughout the study period, and there were noticeable gender differences in the grounds used to petition for divorce. Those who married at a younger age were more likely to divorce, as were those where the age difference between husband and wife was larger than usual. Divorce was primarily an urban phenomenon in the period covered, while Wellington had the highest divorce rate amongst the major New Zealand centres. Although New Zealand never came close to the American divorce rate, for much of this period it had the highest divorce rate in the British Empire.

Figure 2.1

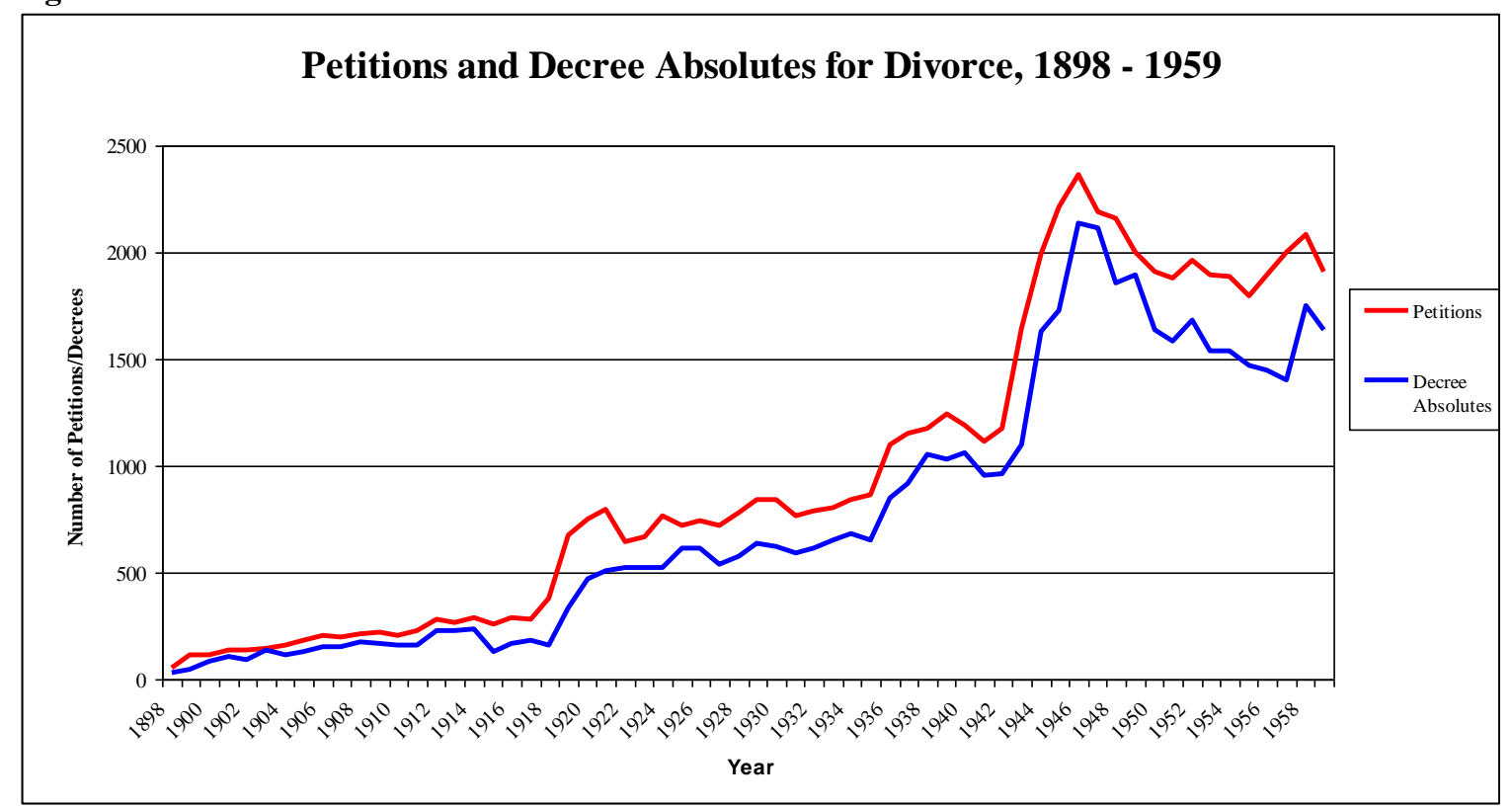

Source: Statistics of New Zealand (data before 1921), Report on Justice Statistics (data from 1921).

\footnotetext{
${ }^{1}$ For a useful examination of general trends in New Zealand divorce compiled in the 1950s see, A.J. Nixon. Divorce in New Zealand: A Preliminary Survey. Auckland: 1954.
} 
As Figures 2.1 and 2.2 indicate, the most notable increases in divorce occurred immediately after World War I and during and after World War II. While the absolute numbers of petitions and divorces decreased after the peak in 1947, the level stabilised at a much higher point thereafter. Throughout the period 1898 to 1959 the number of decrees absolute granted were consistently lower than the number of petitions filed with the court. This difference can be explained by the fact that some petitions did not result in a decree absolute due to the petition not being pursued, or being rejected by the courts. On some occasions a petition was filed and later a new petition was filed in a different court or by the other spouse, resulting in dissolution, but not by the process instigated by the first petition. In general however, a high proportion of petitions lodged proceeded to decree absolute.

Figure 2.2

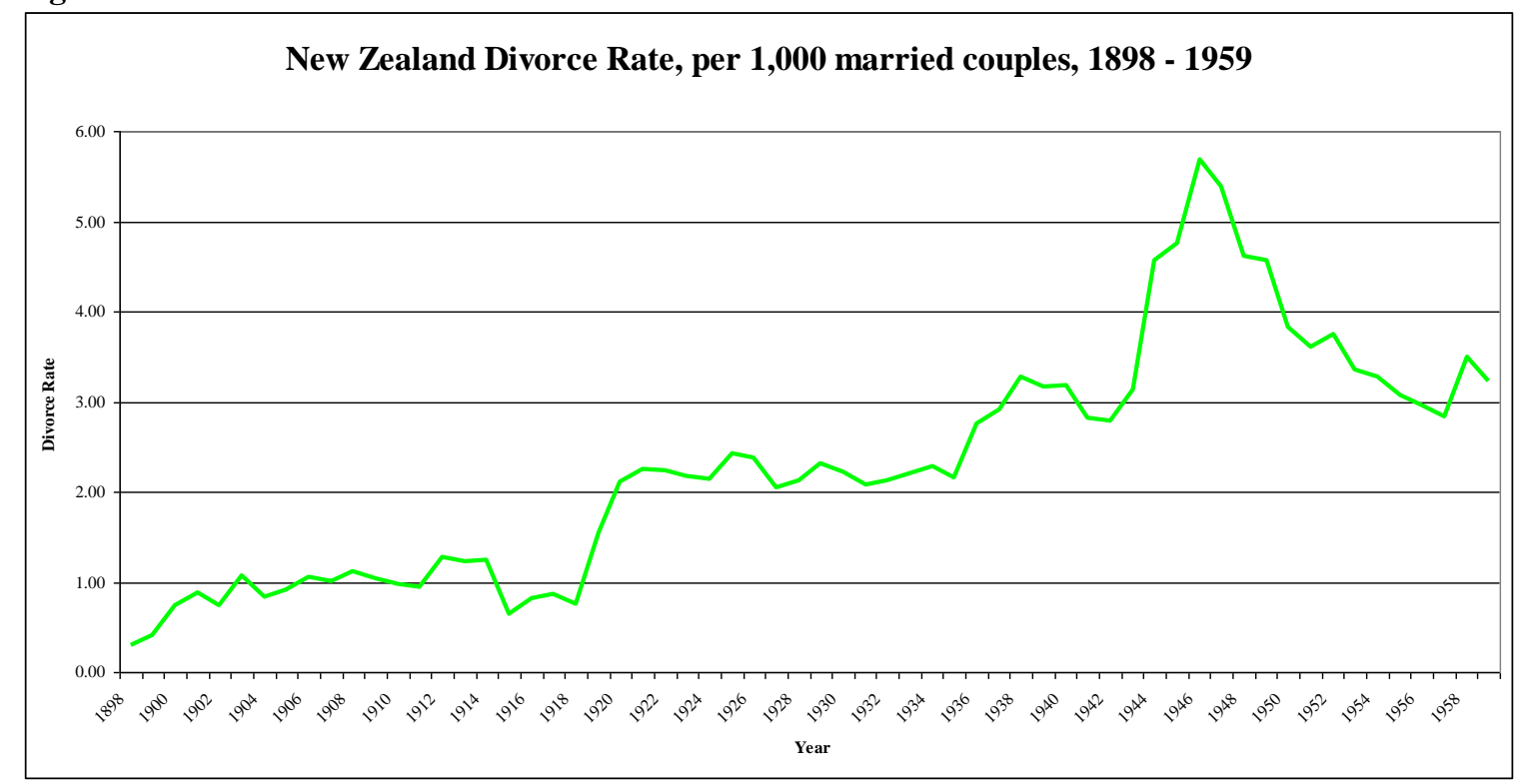

Source: Number of Decrees Absolute obtained from Statistics of New Zealand (data from 1921), Report on Justice Statistics (data after 1921). Number of married people in the population obtained from New Zealand Census.

The divorce rate for New Zealand (Figure 2.2) was calculated using the number of decrees absolute issued in a year as a proportion of the total married couples in the population. Figures of total married couples have been taken from the Census by calculating the median of the number of currently married men and the number of currently married women in the population. A regular rate of population increase has been assumed for years between Census years. 
The dramatic increase in the divorce rate in the early 1920s was a result of the combination of the impact of World War I, and the 1920 introduction of separation of three years or more as a ground for divorce. From the mid-1920s until 1936 the divorce rate slowed its increase. This coincided with a period of economic downturn in New Zealand. Similar patterns have been noted in other countries, particularly in the United States in the 1930s during the Great Depression. As one historian has noted, however, desertions 'skyrocketed' in the United States during the Depression, again emphasising the difference between marriages ending and divorce. ${ }^{2}$

Figure 2.3

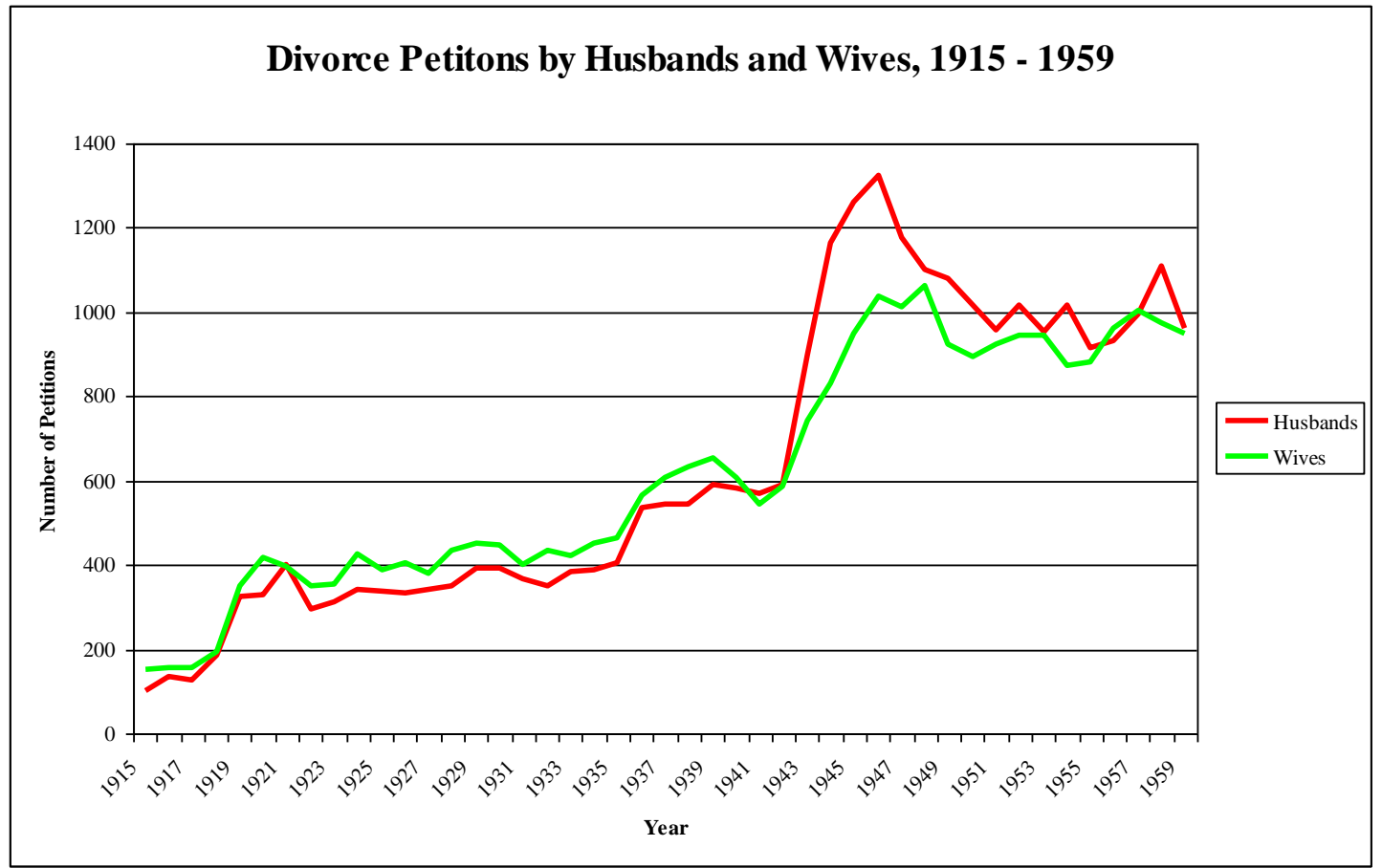

Source: Statistics of New Zealand (data before 1921), Report on Justice Statistics (data from 1921). Officials figures relating to the gender of the petitioner are not available before 1915 .

While Figure 2.3 shows divorce petitions from only 1915, women were more likely to petition for divorce from 1898 onwards, when the double standard that had previously applied to petitioning for divorce was removed, and grounds such as desertion and drunkenness coupled with cruelty were introduced. Women were more likely to make use of these grounds than men. ${ }^{3}$ Women maintained this lead until 1941 when men began to petition for divorce more often than women. Again this points to the significance of World War II in influencing the patterns of divorce in New Zealand. Even after the war

\footnotetext{
${ }^{2}$ J. Herbie DiFonzo. Beneath the Fault Line. The Popular and Legal Culture of Divorce in TwentiethCentury America. Charlottesville, 1997, 30.

${ }^{3}$ The breakdown of divorce petitioners by husbands and wives was recorded only from 1915 in the Statistics of New Zealand and from 1921 in the Report on Justice Statistics.
} 
ended, with the exception of 1957 , men were more likely to petition for divorce than women during the 1950s.

Table 2.1, drawn from the sample of files taken from the Wellington Supreme Court, shows that wives' petitions were much more likely to result in a decree nisi and then a decree absolute than husbands' petitions. While in the overall sample of 2,195 cases husbands comprised over half of all petitioners, over three quarters of their petitions resulted in a decree nisi compared with over 85 per cent of wives' petitions. A higher proportion of wives' petitions resulted in decrees absolute compared with husbands' petitions.

Table 2.1

Success Rate of Husbands and Wives Divorce Petitions in the Wellington Supreme Court, 1898 - 1947

\begin{tabular}{c|ccc}
\hline & $\begin{array}{c}\text { Percentage of } \\
\text { Petitions by } \\
\text { Husbands and } \\
\text { Wives }\end{array}$ & $\begin{array}{c}\text { Percentage of } \\
\text { Petitions made } \\
\text { Decree Nisi }\end{array}$ & $\begin{array}{c}\text { Percentage of } \\
\text { Petitions made } \\
\text { Decree Absolute }\end{array}$ \\
\hline Husbands & $50.4 \%(1107)$ & $76.78 \%(850)$ & $74.07 \%(820)$ \\
Wives & $49.6 \%(1088)$ & $86.49 \%(941)$ & $82.81 \%(901)$ \\
\hline TOTAL & $\mathbf{1 0 0 \% ( 2 1 9 5 )}$ & $\mathbf{8 1 . 5 9 \% ( 1 7 9 1 )}$ & $\mathbf{7 8 . 4 1 \%}(\mathbf{1 7 2 1})$ \\
\hline
\end{tabular}

Source: Wellington Divorce Database.

There are a number of different explanations for the difference in the success rate of husbands and wives petitions. First, due to the financial cost of petitioning for divorce, wives may have had to wait longer than husbands to save the money required. Once having saved the money, however, wives were probably more determined to see the case through to its conclusion than husbands. Secondly, the option of desertion, relocation to another region of New Zealand, or further afield, was more possible for men than women, and so rather than ending their marriages legally, husbands may have chosen to move and begin new lives as single men in a new community. This option was not available to women to the same degree, and as they were more likely to remain in the same community, and so had a greater need to have their legal marital status reflect their actual status.

For most people who divorced, the marriage had been their first. For about six per cent of grooms and eight per cent of brides, however, it was at least their second marriage. Those 
who had previously divorced were more likely to divorce again. ${ }^{4}$ For those who had previously been widowed and had subsequently divorced, a loss of status may have ensued, especially for women. As Chapter Four explores in further detail, charitable aid and government support was far more forthcoming for widows than it was for divorced women, demonstrating the greater standing widowed women had in society compared with divorced women.

Table 2.2

Marital Status at Marriage for those who Divorced in the Wellington Supreme Court, 1898-1947

\begin{tabular}{c|cc}
\hline Marital Status & Grooms & Brides \\
\hline Single & $93.88 \%(1732)$ & $91.62 \%(1705)$ \\
Widowed & $3.20 \%(59)$ & $3.60 \%(67)$ \\
Divorced & $2.92 \%(54)$ & $4.78 \%(89)$ \\
\hline Total & $\mathbf{1 0 0 \% ( 1 8 4 5 )}$ & $\mathbf{1 0 0 \%}(\mathbf{1 8 6 1})$ \\
\hline
\end{tabular}

Source: Wellington Divorce Database.

Table 2.3

Age at Marriage for those who Divorced in the Wellington Supreme Court, 1898-1947

\begin{tabular}{c|ccccc}
\hline & All Grooms & All Brides & $\begin{array}{c}\text { Grooms Not } \\
\text { Previously } \\
\text { Married }\end{array}$ & $\begin{array}{c}\text { Brides Not } \\
\text { Previously } \\
\text { Married }\end{array}$ & $\begin{array}{c}\text { Brides Where } \\
\text { Marriage was } \\
\text { 'Shotgun' }\end{array}$ \\
\hline Mean & 26.24 & 22.83 & 25.51 & 22.04 & 20.59 \\
Minimum & 17 & 15 & 17 & 15 & 15 \\
Maximum & 70 & 66 & 59 & 48 & 48 \\
N & 1811 & 1813 & 1697 & 1661 & 346 \\
\hline
\end{tabular}

Source: Wellington Divorce Database.

Table 2.3 shows the average age at marriage of those who divorced. ${ }^{5}$ Compared with the population as a whole, those who divorced had married at a younger age. While age at marriage varied across the period 1898-1947 from a low of 28.47 years in 1930 to 31.57 years in 1918 for men, and 25.29 years in 1900 to 27.16 years in 1918 for women, it was

\footnotetext{
${ }^{4}$ The percentage of divorced people in the population as a whole varied from 0.06 per cent of men and 0.04 per cent of women in 1901 to 1.18 per cent of men and 1.16 per cent of women in 1945. New Zealand Census, 1901 and 1945.

${ }^{5}$ Comparing the average age at marriage of those who divorced with the population as a whole is not straightforward. Divorce files are arranged by the year in which a petition for divorce was made, and so in any one petition year there were couples who had been married anywhere between less than one year to more than thirty years. While it is possible to arrange the data in the Wellington Divorce Database by year of marriage, the sample size for many years becomes very small, thus the data for the entire period 18981947 had been included in one table, although this involves marriages that were contracted between 1858 and 1947, both inside and outside of New Zealand. The Wellington Divorce Database includes 201 marriages which were contracted before 1898 and 266 marriages which took place outside of New Zealand.
} 
always higher than the average age at marriage for those who divorced. ${ }^{6}$ The average age difference between spouses who divorced was just under 4.4 years, which is higher than for the population as a whole for much of this period. ${ }^{7}$ The average difference in age at marriage for the New Zealand population varied from 4.46 years in 1898 to 3.6 years in 1947, with a low of 2.34 years in $1930 .{ }^{8}$ Of those who divorced, in 275 cases $(15.19 \%)$ the bride was older than the groom with 17 brides being 10 or more years older than their prospective husband with the eldest being 22 years older than her groom. ${ }^{9}$ Ten per cent of couples (189) were the same age, and for another 16 per cent (296) the age gap was only one year. In 1,346 cases (74.36\%) the groom was older than the bride, with 176 grooms being 10 years or more older than their prospective wife, with the eldest being 30 years older than his bride. Not surprisingly, 'shotgun' marriages, which are further considered in Chapter Seven, generally involved young brides. Of those 346 marriages in which a child was born within the first seven months, the bride was 20 years old or younger in 50 per cent of cases, and under 23 in 75 per cent of cases. However, in 10 cases the bride was 30 years old or more and in 2 cases she was in her 40s.

Figures 2.4 and 2.5 show the grounds for divorce as a proportion of total divorce petitions for the period 1915-1960 by husbands and wives. Prior to the introduction of the ground of separation of three years or more in 1920 adultery and desertion were the most common grounds for divorce. While they declined in importance after the change in law in 1920, they remained significant with over 40 per cent of divorce petitions in 1960 citing one of these two grounds. As with World War I the number of petitions on the ground of adultery increased during World War II. At this time failure to comply with a restitution of conjugal rights became increasingly important, but after 1953 when the law was changed to make this only a ground after three years of non-compliance with a restitution order, its significance declined rapidly and it was rarely used. For the sake of simplicity, the three grounds of drunkenness and cruelty, drunkenness and failure to

\footnotetext{
${ }^{6}$ In 1898 the average age at marriage for men was 29.95 years and for women, 25.3 years. In 1947 it was 29.71 years and 26.11 years respectively. All figures concerning the average age at marriage for the New Zealand population comes from the New Zealand Official Year Book, 1916-1950.

${ }^{7}$ Wellington Divorce Database.

${ }^{8}$ These figures are based on the difference between the average age at marriage for men and women given in the New Zealand Official Year Book.

${ }^{9}$ This 15 per cent figure is lower than the 18 per cent that Erik Olssen found in his study of marriages in Southern Dunedin. See “For Better or Worse": Marriage Patterns in Dunedin's Southern Suburbs, 1881 1938', in Class, Gender and the Vote. Historical Perspectives from New Zealand, eds. Miles Fairburn and Erik Olssen. Otago: 2005, 79.
} 
maintain and drunkenness and failure to perform domestic duties have been combined for the purpose of data analysis. These three grounds were used most frequently in the earlier part of the study period, but by the end of the 1920s became statistically insignificant. After 1953 the new ground of living apart for seven or more years began to be used, and by 1960 about eight per cent of all divorce petitions were made on this ground.

Figure 2.4 shows the clear importance of the ground of separation of three years or more to petitioning wives. While it was also the most common ground used by petitioning husbands after 1929, it never accounted for more than fifty per cent of male petitions, whereas for each year from 1931 onwards it accounted for more than fifty per cent of female petitions. The second major difference was the tendency of women to use desertion as a ground and men to use adultery as a ground. By 1960, however, both men and women were more likely to petition on the ground of adultery than desertion. This was probably in part due to the fact that grounds such as separation of three years or more and living apart for seven years or more covered desertion-like situations. Drunkenness and cruelty was a relatively important ground for women to use until the end of the 1920s, and in particular it noticeably increases in the period immediately following World War I.

Men were much more likely to use failure to comply with a restitution of conjugal rights as a ground for divorce than women. This ground essentially allowed for an immediate divorce after a couple separated rather than having to wait three years. The process follows: one spouse petitioned for a restitution of conjugal rights, and then as soon as their partner failed to comply they were able to petition the court again for a divorce. Cost was a downside to this method as it required petitioning the court twice. As well, the petitioning spouse had to state that they truly wanted their partner to return to them, and in the case of husbands, that they were able to provide adequate accommodation as stated in Chapter One. 
Figure 2.4

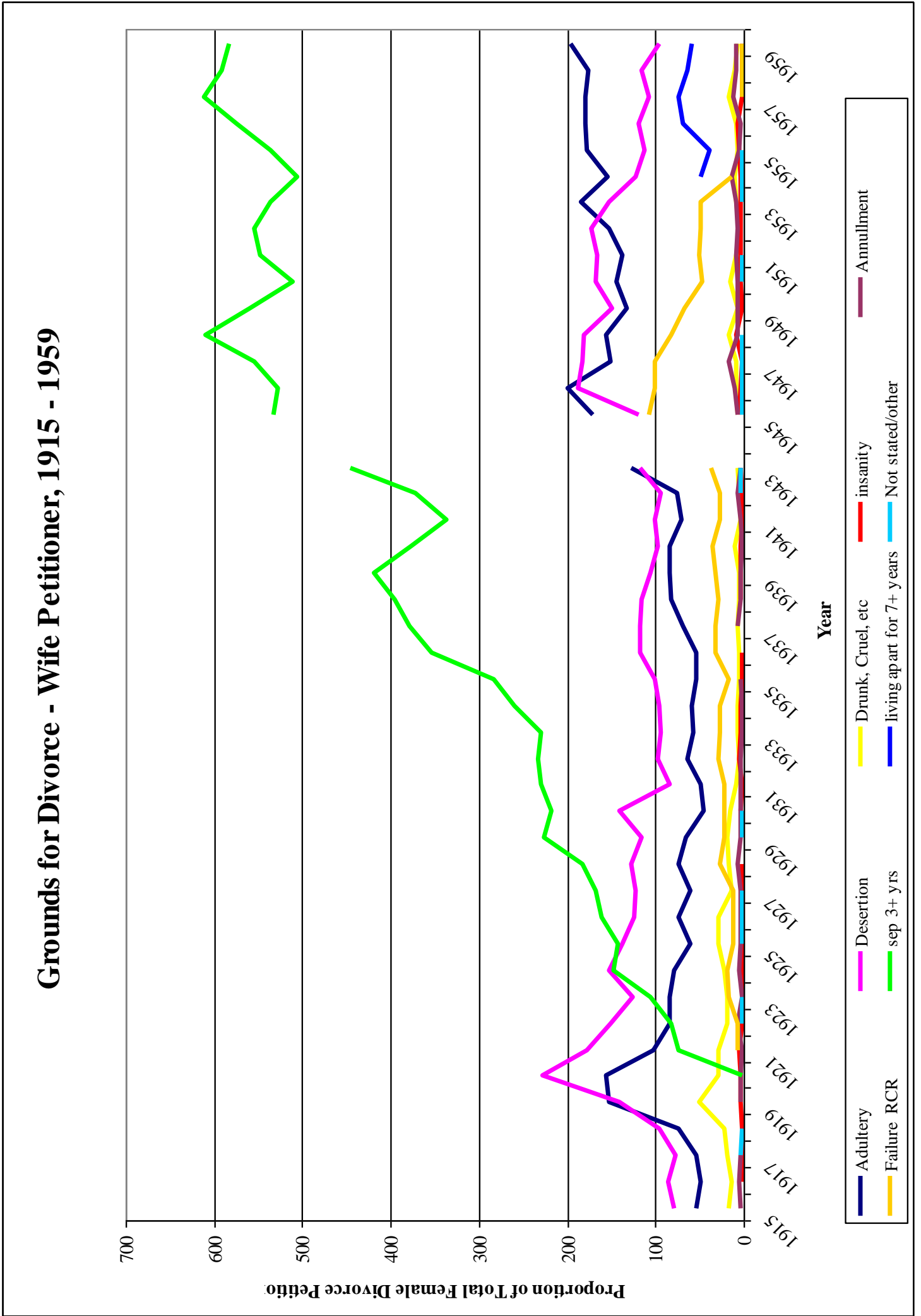

Source: Statistics of New Zealand (data before 1921), Report on Justice Statistics (data from 1921). Statistics were not recorded for individual grounds by petitioner between 1943 and 1945 due to World War II. 
Figure 2.5

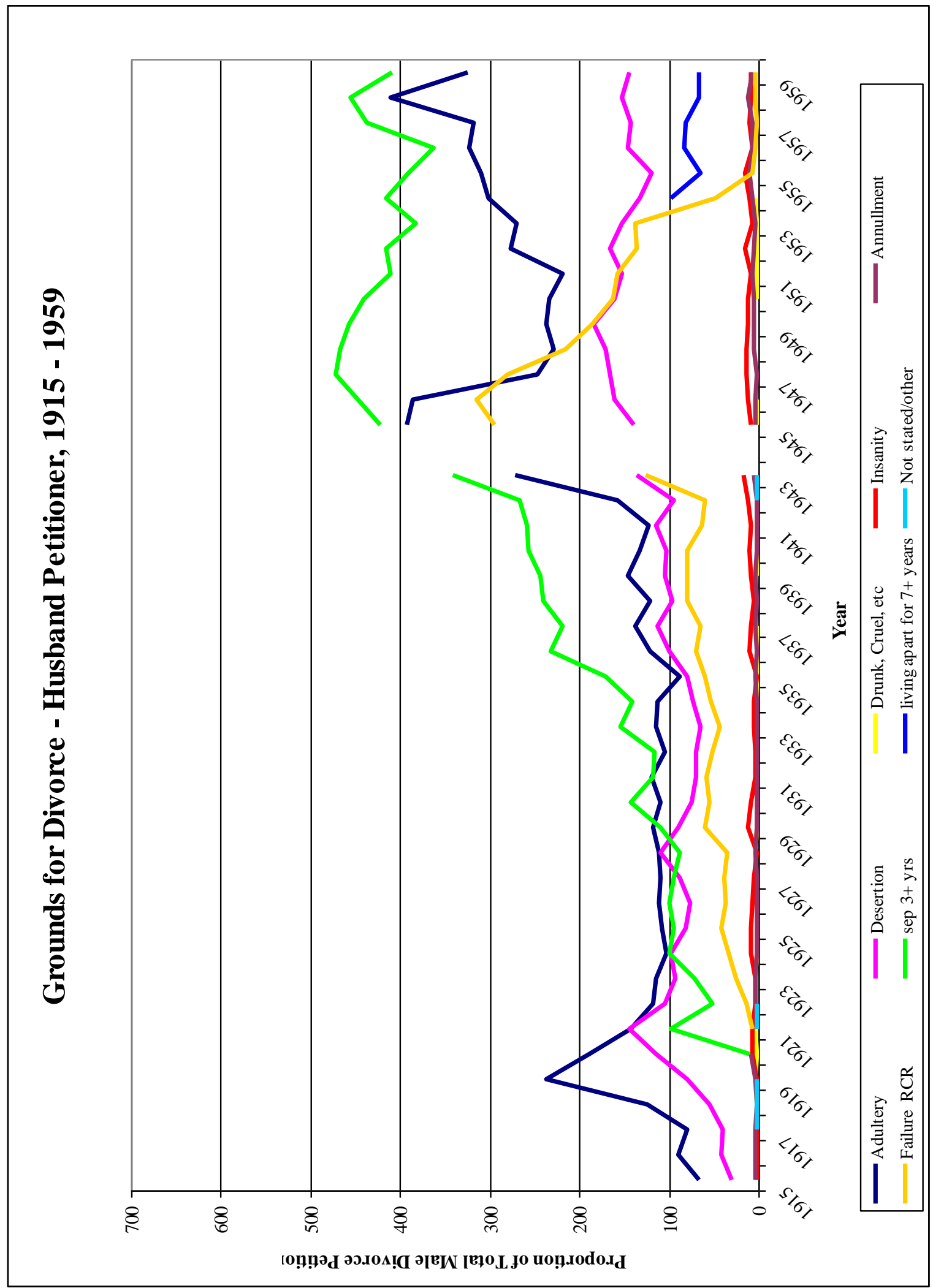

Source: Statistics of New Zealand (data before 1921), Report on Justice Statistics (data from 1921). Statistics were not recorded for individual grounds by petitioner between 1943 and 1945 due to World War II. 
A number of divorce petitions citing separation of three years or more or desertion may have also involved adultery. In such cases the petitioners and/or the respondents decided not to make adultery an official ground for divorce in order to avoid having newspapers report on their divorce in any detail. Conversely there would have been occasions where the exposure created by having one's divorce reported by a newspaper was seen as part of the 'punishment' for a 'marital' crime and some petitioners would feel vindicated in exposing their spouse as an adulterer in cases of acrimonious divorce.

Only a few people used insanity as a ground for divorce during this period, but its use was socially significant. One spouse was required to have been in an institution for ten years (later seven) prior to the petition being filed to meet this ground. Between 1915 and 1960 474 petitions were filed in New Zealand on this ground, with husbands petitioning in 344 cases and wives in 130 cases. As noted above, drunkenness and cruelty was a ground far more likely to be used by wives than husbands. Between 1915 and 1960, 638 petitions were filed on the ground of drunkenness and cruelty, and of these 581 were filed by wives and 57 by husbands. It is perhaps not surprising that this ground was used so much more by wives than husbands, but what is less clear is why this ground was used less and less, particularly after 1930. The ground of drunkenness and cruelty and the ground of insanity are explored further in Chapter Six.

Using the Wellington Divorce Database, Figure 2.6 breaks down the ground of separation of three or more years into four categories. Mutual separation (undefined), accounting for about a quarter of these divorces, involves oral and written separations, but the divorce petition does not make clear which; the second and third categories are oral and written separation recorded separately, and the fourth category involved separations based on separation orders issued by the Magistrates' Court. Only wives could apply for such orders, although either husbands or wives could use the separation order as a ground for a divorce. Also it was difficult to lie about the date of a Magistrates' Court order, but it was much easier to invent the date of an oral separation, especially as some couples may have drifted apart and not have a precise date of separation, and for others it may have been difficult to remember the exact date. 
Figure 2.6

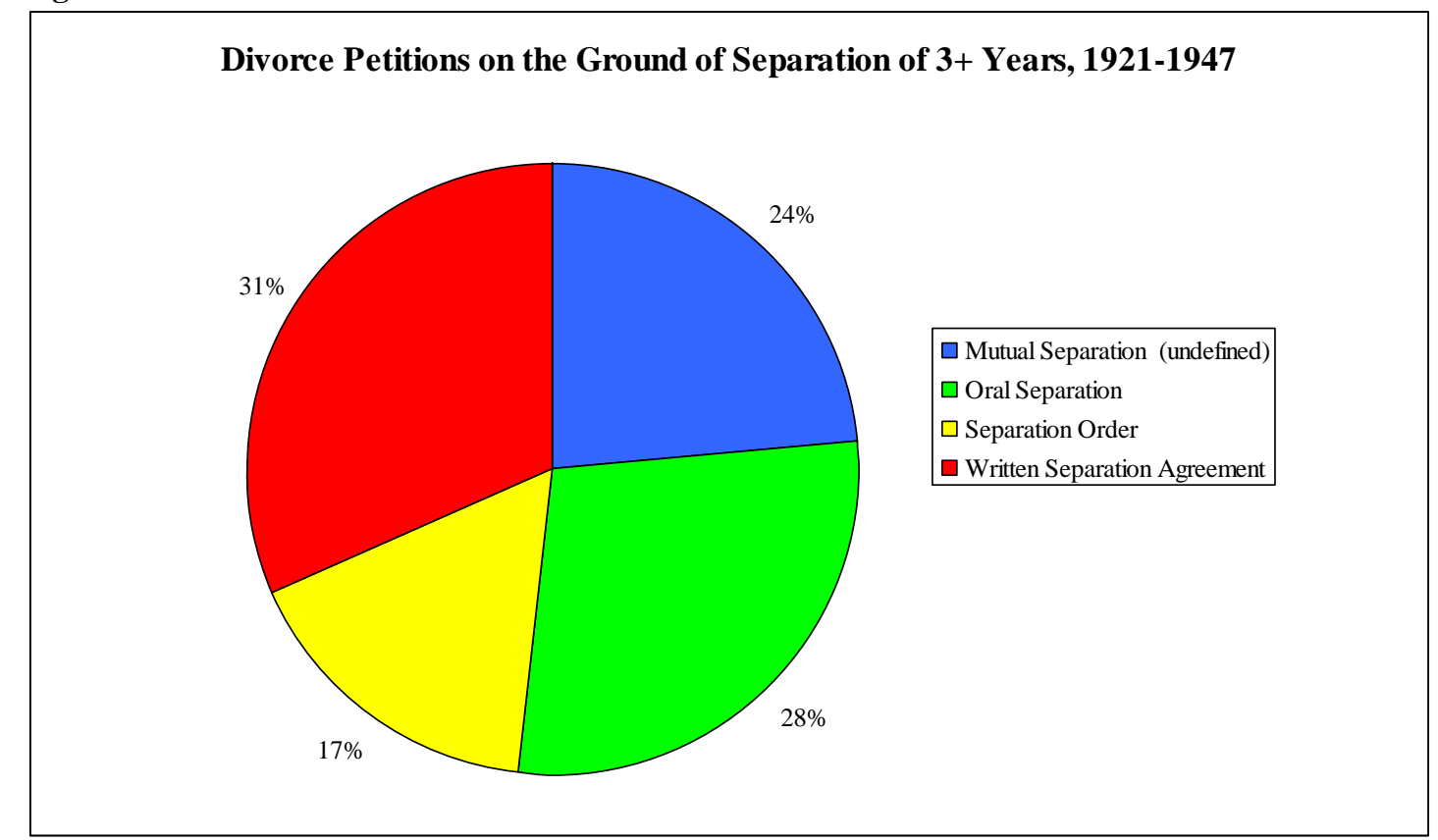

Source: Wellington Divorce Database.

Figure 2.7 shows the proportion of divorce petitions filed in the Wellington Court compared to New Zealand as a whole for this period. Almost half of the petitions in New Zealand were presented to the Wellington Court in 1898. By 1952 this had reduced to about 17 per cent. In part this is due to the growth in population of other areas, especially Auckland (see Figure 2.8) and also due to the formation of a number of extra courts in the lower North Island as well as the growth of the legal profession in the provinces. The Palmerston North Supreme Court was established in 1903, with Wanganui following in 1906, and Masterton in 1910. Napier and New Plymouth had Supreme Court sittings prior to 1898. It was not a requirement to file for divorce in the court closest to one's residence. In 1925, for example, Robert T. petitioned for divorce from his wife on the ground of her insanity. The couple had married in Christchurch in 1915 and according to his petition, had always lived in Christchurch. At the time of petitioning Robert was living in Christchurch and his wife was at Sunnyside Mental Hospital, also located in Christchurch. Both the husband and wife had been born in Canterbury as well, but the husband filed his petition in the Wellington Supreme Court. ${ }^{10}$ Most probably this was done in order to reduce the public exposure of the case in the local community.

\footnotetext{
${ }^{10} T v T$, AAOM/W3265/D2685/1925/ANZ-W.
} 
Figure 2.7

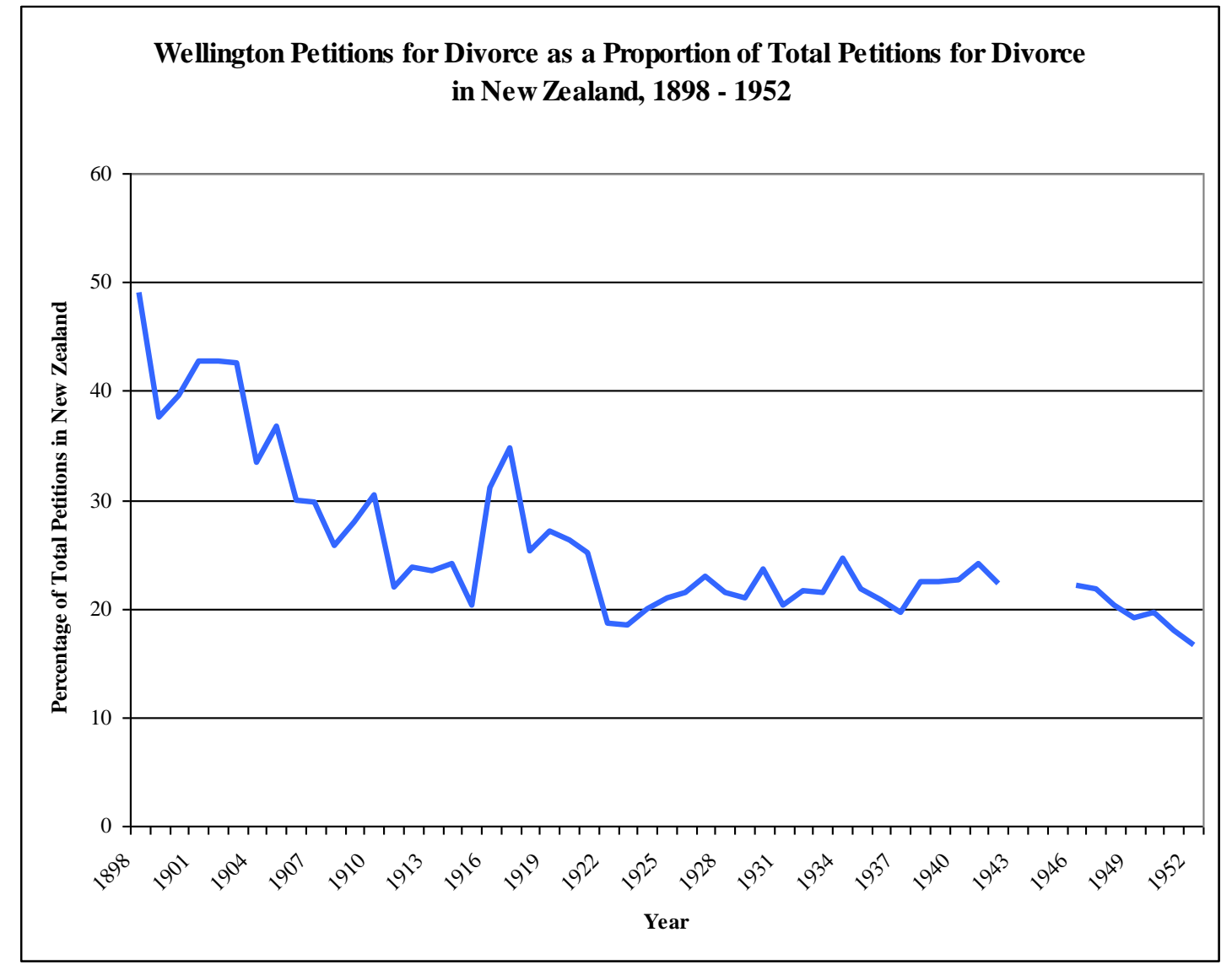

Source: Statistics of New Zealand (data before 1921), Report on Justice Statistics (data from 1921 ). Statistics were not recorded for individual courts between 1943 and 1945 due to World War II. Figures for the Wellington Court are not recorded in the official statistics after 1952.

Figure 2.8 shows the number of petitions being filed in the Supreme Court in each of the four major urban centres between 1898 and 1952. Taking into account the population of each city, Wellington had the highest divorce rate, followed closely by Auckland, with Christchurch and Dunedin having substantially lower rates. In 1926, of the fourteen major urban areas, Auckland and Wellington had the highest proportion of divorced people (as well as the highest proportion of legally separated people) in their populations. Both Gisborne and Palmerston North had a higher proportion of divorced persons in their populations than Christchurch or Dunedin, which both had proportions equal to that of Hamilton, Napier and Nelson, followed by the remaining urban centres. ${ }^{11}$ This pattern continued through to the postwar period. Urban populations had a higher proportion of divorced persons than rural populations, ${ }^{12}$ but there was also a divide between the urban areas of the North and South Islands. As the divorce files consulted for this study are all from the Wellington Court, it is difficult to explain these regional differences without

\footnotetext{
${ }^{11}$ New Zealand Census 1926, 'Conjugal Condition of the Population', 4.

${ }^{12}$ New Zealand Census 1945, 'Age and Marital Status Report', 8.
} 
further research being conducted. Perhaps the Anglican Church in Christchurch and the Presbyterian Church in Dunedin had a greater influence over the population than the churches in Wellington and Auckland did. ${ }^{13}$

Figure 2.8

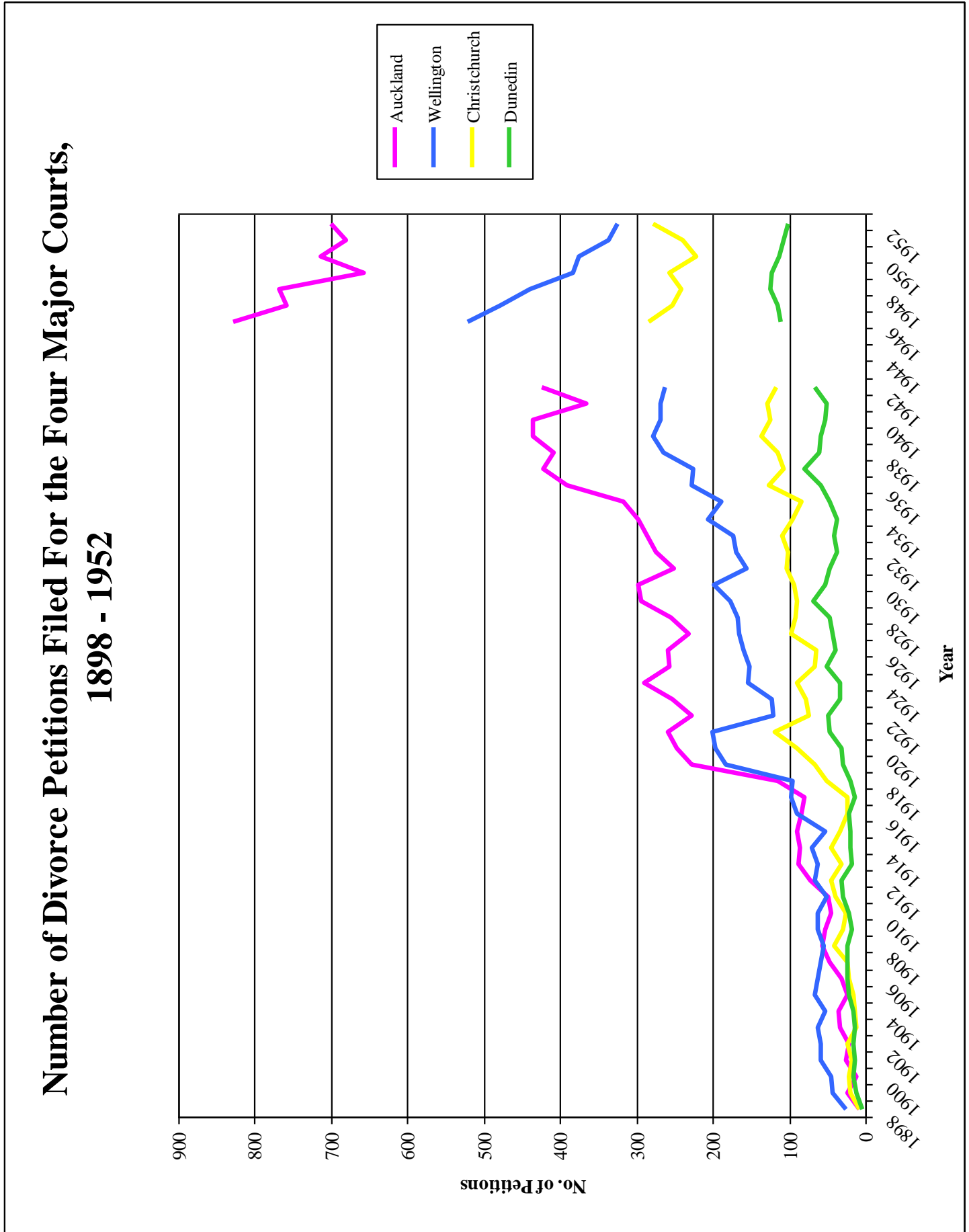

Source: Statistics of New Zealand (data before 1921), Report on Justice Statistics (data from 1921). Statistics were not recorded for individual courts between 1943 and 1945 due to World War II.

\footnotetext{
${ }^{13}$ John Stenhouse has argued for the strength of religion and the relative conservatism of Christchurch and Dunedin. See John Stenhouse, 'Religion and Society', in The New Oxford History of New Zealand, ed. Giselle Byrnes. Melbourne: 2009, 341.
} 
When New Zealand's divorce rate is examined in an international context, it becomes apparent that the rate in New Zealand was higher than that in Australia, England, Scotland or Canada (Figure 2.9). These rates were calculated based on the total population, rather than the total married population which potentially could affect the results, although the structure of the populations in these countries was broadly similar. The Australian states had separate laws until 1959 when a federal divorce law was passed, however in this graph the total population of Australia has been used concealing any differences between states. This also applies to Canada, where each province had a different law until 1968. The major difference between New Zealand and the other Commonwealth countries considered is the existence of separation of three years or more as a ground for divorce. None of the other countries considered had a ground of this nature during this period. However, this does not fully explain the difference as New Zealand's divorce rate is higher prior to 1920, although it did have a more liberal law compared to Canada and England before 1920 as well.

\section{Figure 2.9}

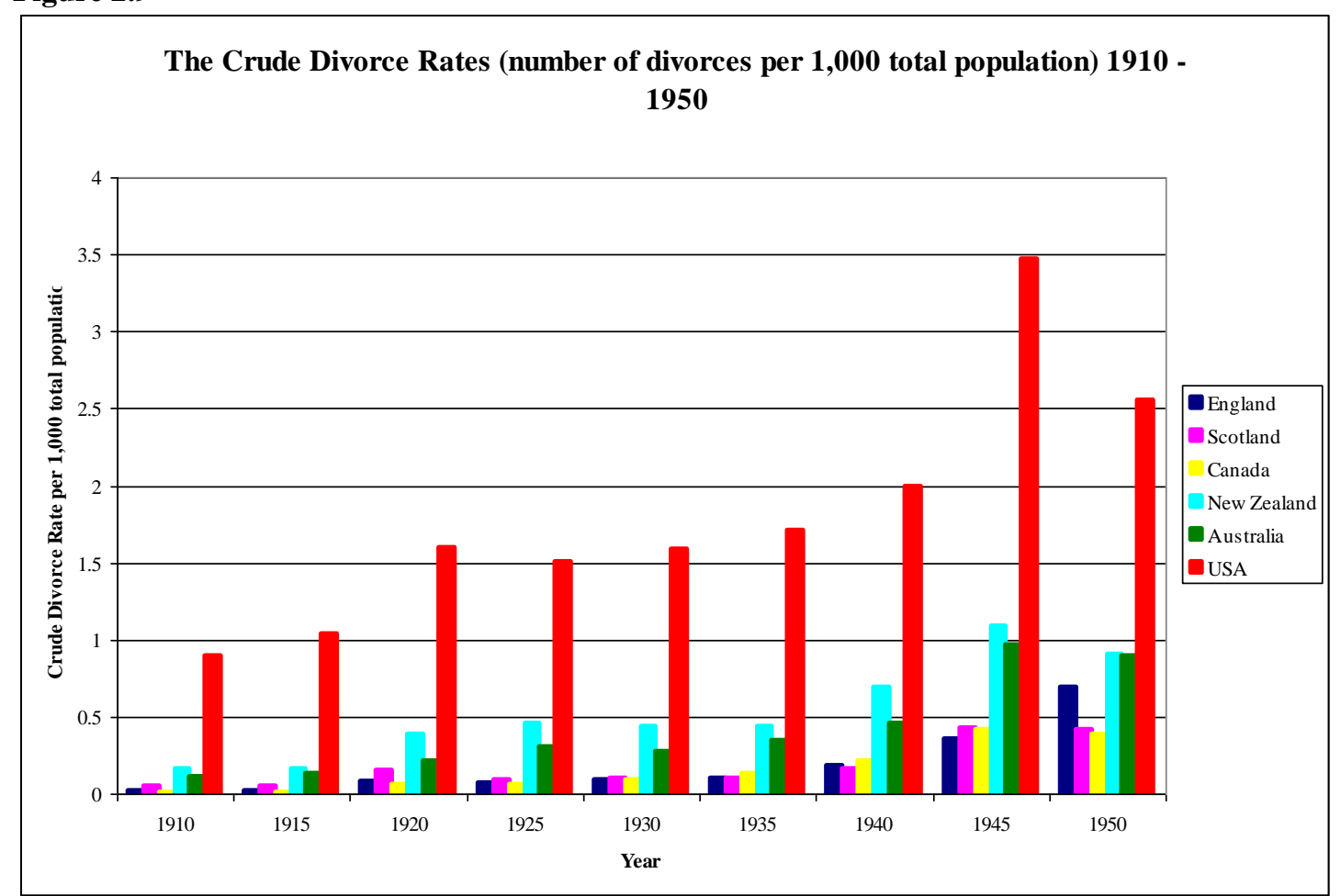

Source: Royal Commission on Marriage and Divorce Report 1951- 1955 (UK), Appendix II, table 5. (The Commission did not comment upon these figures in its final report).

While there are differences between England, Scotland and the three former settler societies, when compared to the United States these differences appear to be not so great. 
Like Australia and Canada, divorce law in the United States varied (and varies) from state to state, but people also moved (often temporarily) to states such as Nevada to take advantage of more lenient laws, so an overall rate for the country is still useful. All countries show the influence of World War I and II, albeit some more starkly than others.

Religion played an important role in some people's decision to divorce or not, and more generally the major churches attempted to influence the shaping of New Zealand's divorce law, although New Zealand had no state religion. Census statistics (Table 2.4) show Anglicans and Catholics were more likely than Presbyterians and Methodists to be divorced, despite marriage being a sacrament in the former churches and not in the latter. This may in part be explained by the Anglican Church operating as the 'default' church for many who were not particularly religious. ${ }^{14}$

Table 2.4

Percentage of Divorced Persons by Gender and Religious Affiliation for the Four Main Denominations 1926-1956

\begin{tabular}{c|cc|cc|cc|cc}
\hline & \multicolumn{2}{|c|}{1926} & \multicolumn{2}{c|}{1936} & \multicolumn{2}{c|}{1945} & \multicolumn{2}{c}{$\mathbf{1 9 5 6}$} \\
\hline & Men & Women & Men & Women & Men & Women & Men & Women \\
Anglicans & 0.5 & 0.4 & 0.8 & 0.8 & 1.2 & 1.3 & 1.1 & 1.4 \\
Presbyterians & 0.3 & 0.2 & 0.5 & 0.4 & 0.8 & 0.7 & 0.8 & 0.9 \\
Catholics & 0.4 & 0.3 & 0.7 & 0.6 & 0.9 & 0.8 & 1.0 & 1.0 \\
Methodists & 0.3 & 0.3 & 0.5 & 0.5 & 0.7 & 0.8 & 0.8 & 0.9 \\
\hline
\end{tabular}

Source: New Zealand Census, 1926-1956. Figures are not available before 1926.

A long-term decline in church attendance began in the Protestant churches from 1886, but Presbyterians and Methodists continued to have a higher rate of attendance than Anglicans. ${ }^{15}$ James Belich has argued that the decline in Protestant church attendance does not reflect a decline in 'broader religiousness'. Instead, he argues, 'a vague and vaguely interdenominational Protestantism' existed and was associated with moral evangelism. ${ }^{16}$ John Stenhouse, on the other hand, has emphasised the importance of religion, and the fact that almost all Protestant children attended Sunday school, and almost all Catholic children attended Catholic schools, which meant the vast majority of

\footnotetext{
${ }^{14}$ Erik Olssen. 'Towards a New Society', in The Oxford History of New Zealand, $2^{\text {nd }}$ ed. ed. Geoffrey Rice. Auckland: 1992, 270.

${ }^{15}$ James Belich. Paradise Reforged. A History of the New Zealanders from the 1880s to the Year 2000. Auckland: 2001, 163; Hugh Jackson. 'Churchgoing in Nineteenth-Century New Zealand'. NZJH 17, no.1 (1983): 43-59.

${ }^{16}$ Belich, 164-65.
} 
New Zealanders had a strong religious background, even if they were not frequent church goers as adults. ${ }^{17}$ There was also a gender imbalance among church attendees with women outnumbering men in most Protestant churches, slightly among adherents and in greater numbers when it came to active church participation. ${ }^{18}$ With regards to divorce, this meant that while one spouse may have been morally opposed to divorce, if the other spouse was not, and had a ground for divorce, it could still be initiated and obtained.

Figure 2.10 shows the location of wedding ceremonies for those who subsequently divorced. While the majority of divorcees had been married by clergy either in a church or at a private residence, a higher proportion than the population as a whole had been married in a registry office. It cannot be concluded that couples who married in a registry office had no religious affiliation, as there were a number of reasons a couple might choose to marry in a registry office. These reasons included that the bride may have already been pregnant, the couple could not afford a larger ceremony and reception, the wedding had been quickly organised, or the couple did not have the support of their families. These situations at the time of marriage made the couple more likely to divorce so it is difficult to know whether it was the civil wedding, or the factors which contributed to couples deciding to have a civil ceremony, which increased their likelihood to divorce.

\footnotetext{
${ }^{17}$ John Stenhouse, 'Religion and Society', 345. For a history of children's participation in institutional religion see, Geoffrey Troughton. 'Religion, Churches and Childhood in New Zealand, c.1900-1940'. NZJH 40, no.1 (2006): 39-56. Charlotte Burgess has highlighted the important role churches played as a place for young people to socialise and meet potential partners. This was another way churches could influence people's beliefs about marriage (and divorce). See Charlotte Burgess. 'Looking to the Heart: Young People, Romance and Courtship in Interwar New Zealand'. MA thesis, University of Auckland, 2007, 65-99.

${ }^{18}$ John Stenhouse. 'God, the Devil and Gender', in Site of Gender. Women, Men and Modernity in Southern Dunedin 1890-1939. eds. Barbara Brookes, et al. Auckland: 2003, 326.
} 
Figure 2.10

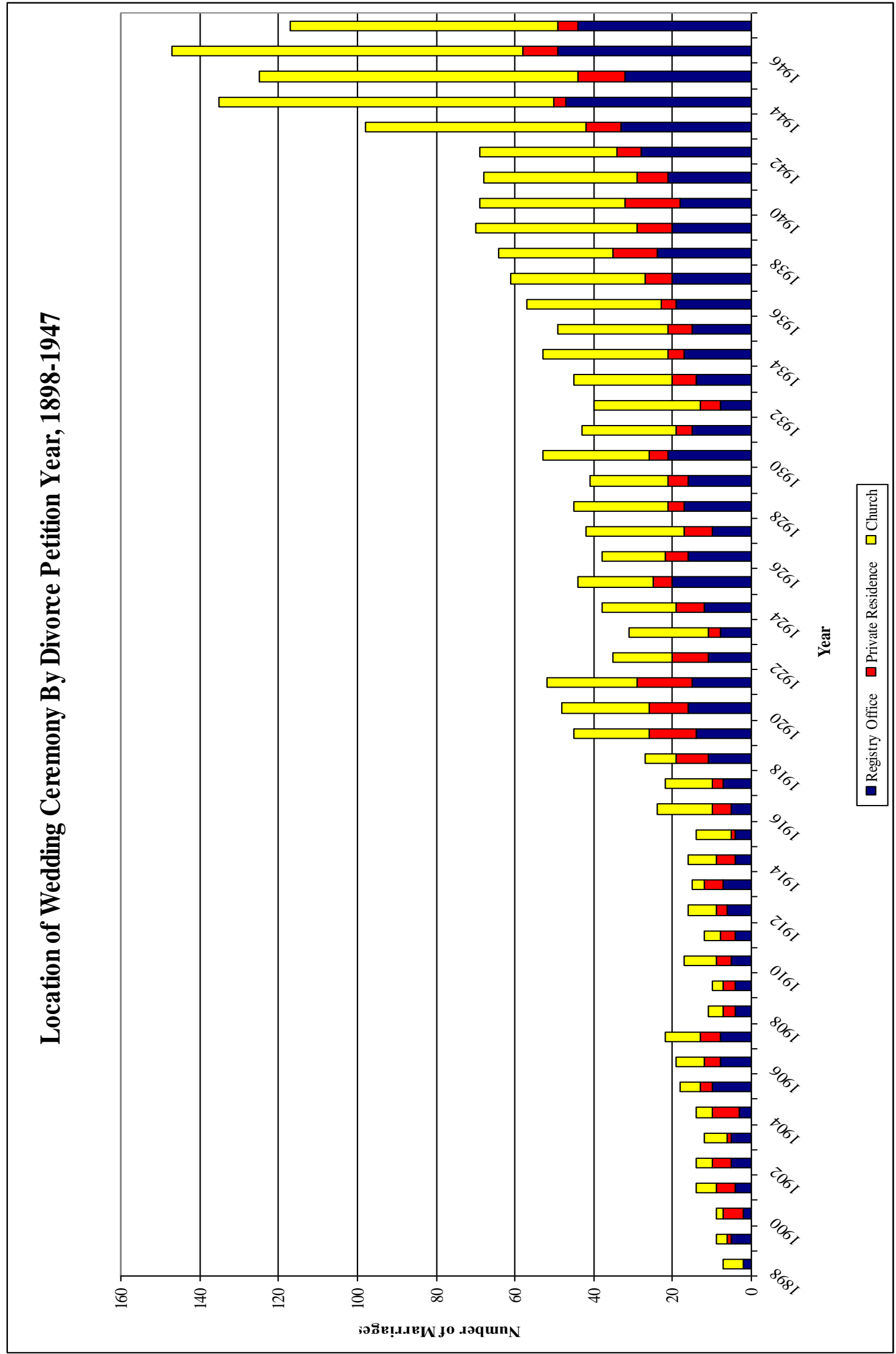

Source: Wellington Divorce Database. 
Of those marriages which took place in a church, the four main denominations are represented in approximately the same proportions as in the population as a whole, although Anglicans and Catholics are slightly overrepresented (Table 2.5). The denomination of the church in which the couple was married is most likely reflective of the affiliation of one spouse, but not perhaps the other. This difference may be explained by the fact that all Anglican and Catholic weddings took place within a church whereas some Presbyterian and Methodist weddings were conducted by clergy at a private residence. $^{19}$

Table 2.5

Location of Marriage by Denomination of Church, 1898-1947

\begin{tabular}{l|ccc}
\hline & Percentage & Number & $\begin{array}{c}\text { Percentage of } \\
\text { the Population } \\
\text { as a Whole }\end{array}$ \\
\hline Anglican Church & 44.74 & 515 & $37-43 \%$ \\
Presbyterian Church & 22.85 & 263 & $23-24 \%$ \\
Catholic Church & 17.46 & 201 & $13-14 \%$ \\
Methodist Church & 8.08 & 93 & $8-11 \%$ \\
Other & 6.86 & 79 & \\
\hline TOTAL & $\mathbf{9 9 . 9 9}$ & $\mathbf{1 1 5 1}$ & \\
\hline Sorce & & & \\
\hline
\end{tabular}

Source: Wellington Divorce Database and New Zealand Census, 1901-1945.

As Table 2.6 shows 'shotgun' marriages (defined as those where a baby was born within the first seven months of marriage) were most common in Registry Office weddings. There is, however, a significant difference between the proportions of marriages that were 'shotgun' in each of the four major churches. Most noticeably, just over 10 per cent of Anglican weddings were 'shotgun', whereas more than 21 per cent of Catholic weddings were 'shotgun', with the figures for the Presbyterian and Methodist churches falling somewhere in between. It is difficult to explain the comparatively low rate of shot-gun marriages which took place in Anglican churches. Perhaps couples who would have normally married in an Anglican church, but found that the bride was pregnant prior to the wedding, were more likely to then marry in a Registry office, whereas in the other denominations which had a higher level of religious observance, weddings took place in the church regardless of whether the bride was pregnant or not. This low rate may also be

\footnotetext{
${ }^{19}$ The marriage certificates contained in the divorce files do not make clear the religious affiliation of those clergy who married couples at a private residence, although this could be traced through the gazetted 'Officiating Ministers' but time constraints meant this was not possible for this project.
} 
reflective of the Anglican Church being the church of 'the upper middle class ${ }^{20}$ and that stricter control was placed on young women from this class background resulting in fewer pre-marital pregnancies. The upper middle class, however, did not make up the majority of the Anglican congregation, although few unskilled workers attended the church, 'it did command the loyalty of a socially mixed flock'. ${ }^{21}$ Catholics were overrepresented in poorer suburbs, and the Methodist church had a strong working class following and the controls placed upon the sexual behaviour of single women from these backgrounds may not have been as great. ${ }^{22}$

Table 2.6

Percentage of Marriages which were 'Shotgun' by Location of Wedding Ceremony, 1898-1947

\begin{tabular}{c|c}
\hline & Percentage of 'Shotgun'Marriages \\
\hline Anglican Church & 10.29 \\
Presbyterian Church & 17.49 \\
Catholic Church & 21.89 \\
Methodist Church & 19.35 \\
Private Residence & 19.45 \\
Registry Office & 23.99 \\
\hline
\end{tabular}

Source: Wellington Divorce Database.

Petitions for divorce and decrees absolute increased both in absolute numbers and proportionally between 1898 and 1947. For much of this period New Zealand had the highest divorce rate in the British Empire, although it never approached the American divorce rate. From the introduction of the Divorce Act 1898, until the middle of World War II, wives were more likely to petition for divorce than husbands, and throughout the study period were always more likely to gain a decree nisi and then a decree absolute than husbands. Those who had divorced once were more likely to divorce a second time and those who married at a younger age than average were also more prone to divorce. Marriages in which there was a significant age difference between husband and wife were more likely to end in divorce. Wife petitioners were most likely to rely on the grounds of

\footnotetext{
${ }^{20}$ Olssen. 'Towards a New Society', 270.

21 Ibid.

${ }^{22}$ On Catholics see, Olssen. 'Towards a New Society', 270. John Stenhouse has also found in his study of Southern Dunedin that Catholics were slightly more likely to be working-class than Protestants. See 'Church, Occupation and Class in Southern Dunedin, 1890-1940' in Class, Gender and the Vote. Historical Perspectives from New Zealand, eds. Miles Fairburn and Erik Olssen. Otago: 2005, 68. On Methodists see, Libby Plumridge. 'The Necessary but not Sufficient Condition: Christchurch Labour and Working-Class Culture'. NZJH 19, no.2 (1985): 134.
} 
desertion, adultery, and from 1920 separation of three years or more, while husband petitioners relied primarily on adultery as a ground. Less frequently used grounds were also gendered. Wives primarily used the ground of drunkenness and cruelty or failure to maintain, and husbands primarily used the ground of insanity. Religious affiliation could also influence a person's decision to divorce or not, although this is harder to measure. A higher proportion of divorcees were married in a registry office than the population as a whole, but the reasons for couples choosing a registry office ceremony are complicated. Anglicans and Catholics were more likely to be divorced than Presbyterians and Methodists despite the Anglican and Catholic churches viewing marriage as a sacrament. The significance and detail revealed by general trends outlined in this chapter are further explored in subsequent chapters. 


\section{Chapter Three}

\section{Divorce in the Time of War}

War caused a significant rupture in the personal lives of many New Zealanders with the number of petitions for divorce in New Zealand increasing dramatically after World War I and during and immediately after World War II. This pattern also occurred in Britain, Australia, Canada and the United States. ${ }^{1}$ Moreover, the number of petitions stabilized at much higher numbers after both wars compared to the pre-war figures suggesting that wartime conditions had effects that persisted after the wars. From 1914 to 1921 there was a 174 per cent (132 per cent increase between 1914 and 1919) increase in the number of divorce petitions, and from 1939 to 1946 there was a 90 per cent increase in the number of petitions. Griselda Rowntree and Norman Carrier, writing about England, suggest the 'unprecedented increase meant that many people, previously quite unacquainted with divorce, found some of their friends or relatives involved in proceedings', and this in itself contributed to the incidence of divorce stabilising at a much higher rate after both wars. $^{2}$

This war-associated increase in divorce has attracted historical attention, but the dynamics behind the dramatic increase require careful analysis, which this chapter undertakes. What is difficult to pinpoint is the exact relationship between war and divorce, especially on a home front so distant from the major theatres of war. Even Deborah Montgomerie, who has emphasised the limits of wartime change, has argued that many men and women experienced World War II 'as a period of considerable personal ambivalence'. ${ }^{3}$ The disruption to life and especially to relations between women and men during wartime might offer an obvious rationale for the dramatic increase in divorce, but a careful analysis of the cases in these years belies such an easy and straightforward explanation.

\footnotetext{
${ }^{1}$ See James Snell. In the Shadow of the Law. Divorce in Canada 1900-1939. Toronto: 1991, 9; Glenda Riley. Divorce. An American Tradition. Lincoln: 1991, 133; Gail Braybon and Penny Summerfield. Out of the Cage. Women's Experiences in Two World Wars. London: 1987, 212-14; Roderick Phillips. Putting Asunder. A History of Divorce in Western Society. Cambridge: 1988, 516-23.

${ }^{2}$ Griselda Rowntree and Norman H. Carrier. 'The Resort to Divorce in England and Wales, 1858-1957'. PS 11, no.3 (1958): 199.

${ }^{3}$ Deborah Montgomerie. 'Sweethearts, Soldiers, Happy Families: Gender and the Second World War', in The Gendered Kiwi, eds. Caroline Daley and Deborah Montgomerie. Auckland: 1999, 172.
} 
Historians and others have argued that war, especially in its twentieth century form, is a gendering activity with militarism, and the associated weight placed on masculine qualities, rearranging gender relations. ${ }^{4}$ Montgomerie has asserted that because 'making war was seen as a profoundly masculine activity, it had the potential to rend great tears in the social fabric by exaggerating the masculine qualities of all its participants, male and female'. ${ }^{5}$ At the same time, Montgomerie also highlights concerns that military service, 'the apex of masculine citizenship', might result in men becoming 'too different from women to comfortably fit back into civilian society'. ${ }^{6}$ In contrast pro-natalist concerns generated by the wartime deaths and wounding of men of prime reproductive age and of civilians, meant that women's reproductive role received greater emphasis along with a yearning for a return to domesticity and 'normality'. War disrupted economic and domestic relations, sexuality, and the meanings of masculinities and femininities, particularly for young adults, more likely to be directly affected by war. ${ }^{7}$ Young men and women were mobilised, travelled to new places, took up new jobs and wore new uniforms. ${ }^{8}$ Specific circumstances during war, as Marilyn Lake has argued, such as 'the stationing of foreign troops in a country' may have 'the effect of sexualizing the local female population...And war conditions, as concerned contemporaries told each other, undermined traditional restraints and disciplines. Faced with an uncertain future, people lived for the day, seizing pleasure when and where they might find it'. 9

Phil Goodman has asserted that 'patriotic femininity' and 'patriotic masculinity', created in public discourses during war, generate 'a heightened sense of heterosexuality. In response to this heightened sense of heterosexuality there was the construction of discourses to contain women and female sexuality'. ${ }^{10}$ The presence of prostitution and

\footnotetext{
${ }^{4}$ Margaret Randolph Higonnet, et al. 'Introduction,' in Behind the Lines. Gender and the Two World Wars, eds. Higonnet et al. New Haven: 1987, 4. Marilyn Lake. 'Mission Impossible: How Men Gave Birth to the Australian Nation - Nationalism, Gender and Other Seminal Act'. G\&H 4, no.3 (1992): 305-22.

${ }^{5}$ Montgomerie, 'Sweethearts, Soldiers, Happy Families', 167.

${ }^{6}$ Ibid., 167-68.

${ }^{7}$ Penny Summerfield and Nicole Crockett. "'You Weren't Taught that with the Welding": Lessons in Sexuality in the Second World War'. WHR 1, no.3 (1992): 435-36.

${ }^{8}$ Kate Darian-Smith has explored how war impacts most greatly on the young and 'highlighted divisions between young and old'. See, Kate Darian-Smith. 'Remembering Romance: Memory, Gender and World War II', in Gender and War. Australians at War in the Twentieth Century, eds. Joy Damousi and Marilyn Lake. Cambridge: 1995, 124-27.

${ }^{9}$ Marilyn Lake. 'Female Desires: The Meaning of World War II'. AHS 21, no.95 (1990): 275.

${ }^{10}$ Phil Goodman. "Patriotic Femininity": Women's Morals and Men's Morale During the Second World War'. G\&H 10, no.2 (1998): 278; See also Susan R. Grayzel. Women and the First World War. London: 2002, 62-78; Sonya O. Rose. 'Sex, Citizenship, and the Nation in World War II Britain'. American Historical Review 103, no.4 (1998): 1147-76; Katie Holmes. "Filling the Empty Cradles”: Sexuality,
} 
other non-marital forms of sexuality have also been noted as increasing during war time. ${ }^{11}$ There was much emphasis on sexuality during war, and many were 'living for the moment'. At the same time, women's sexuality often came under increasing surveillance as any 'immoral' behaviour was considered to have a detrimental effect on their boyfriends and husbands serving overseas. It was believed the morale of the soldiers had to be maintained at all costs as the fate of the country relied on it. ${ }^{12}$ All of these factors need to be examined in order to explain why divorce rates increased during and after major wars. There is more focus in this chapter on World War II than World War I, in part because far more divorces (in absolute numbers) occurred during World War II, but also because the New Zealand historiography of World War II is far more comprehensive than that of World War I. ${ }^{13}$

Much of the international literature, particularly American studies of World War II, focus on issues of separation while men are serving overseas, and the possible trauma that men who serve on the front line experience to explain the increase in divorce. ${ }^{14}$ In World War I, the New Zealand government policy restricted the deployment of married men to the front lines. Long separations or the psychological effects of a husband serving on the front line therefore did not cause the increasing number of divorces between 1919 and 1921. Rather, the rising divorce rate reflected a change in societal values and practices of the time. This argument is further reinforced by the fact that the divorce rate did not decrease in the 1920s, but continued to increase. This New Zealand evidence suggests that separation is not a sufficient explanation. The evidence in the Wellington Divorce

Maternity, and the Effects of Depression and War on Gender Relations in Australia', in Through Depression and War: The United States and Australia, eds. Roger J. Bell and Peter Edward. Sydney: 2002, 51-61.

${ }^{11}$ Grayzel, Women and the First World War; John D'Emilio and Estelle B. Freedman. Intimate Matters: A History of Sexuality in America. New York: 1988, 260-261, 289-91; Allan Berube. Coming Out Under Fire: The History of Gay Men and Women in World War Two. New York, 1990, especially 98-127.

${ }^{12}$ Philomena Goodman. Women, Sexuality and War. Houndmills: 2002, 127-55.

${ }^{13}$ John Crawford and Ian McGibbon have noted a dearth of historical studies of World War I. See, 'Introduction', in New Zealand's Great War. New Zealand, The Allies \& The First World War, eds. John Crawford and Ian McGibbon. Auckland: 2007, 17.

${ }^{14}$ Even though the United States did not enter World War I until 1917, the divorce rate did spike and then stabilize at a higher rate than prior to the war. See, William L. Anderson and Derek W. Little. 'All's Fair: War and Other Causes of Divorce From a Beckerian Perspective'. American Journal of Economics and Sociology 58, no.4 (1999): 903. For other works that focus on the relationship between war and divorce see, Eliza K. Pavalko and Glen H. Elder, Jr. 'World War II and Divorce: A Life-Course Perspective'. The American Journal of Sociology 95, no.5 (1990): 1213-34. For a study of American soldiers who served in the Vietnam War see, Cynthia Gimbel and Alan Booth. 'Why Does Military Combat Experience Adversely Affect Marital Relations?' Journal of Marriage and the Family 56, no.3 (1994): 691-703; Vaughn R. A. Call and Jay D. Teachman. 'Life-Course Timing and Sequencing of Marriage and Military Service and Their Effects on Marital Stability’. Journal of Marriage and Family 58, no.1 (1996): 219-26. 
Database is suggestive of a different explanation that focuses more on the subtle cultural changes that occurred during war rather than the mass enlistment of men into the military.

Arthur Marwick, in his 1965 work on British society during World War I, claimed the threefold increase in divorces between 1910 and 1920 represented 'a fundamental cracking in the cement of conventional society as the Victorians understood it'. ${ }^{15} \mathrm{He}$ also focused on other changes in British society including women wearing trousers, shorter hemlines, and the advent of the cinema. Grayzel has noted similar changes along with women drinking alcohol and smoking cigarettes publicly and using 'strong language'. She attributes this behaviour in part to more middle-class and upper-class women being unchaperoned in public and the increased participation of women in paid work. ${ }^{16}$ While it is difficult to explain exactly what it is about war that results in more people seeking to divorce as patterns of beliefs and personal values are not easily documented, Marwick and Grayzel's attention to cultural changes that coincide with war is useful.

While many changes during wartime were believed to be only 'for the duration', many cultural changes persisted. War did not transform everyone's lives, but it intensified feelings of 'living for the moment' and acted as an accelerant, loosening marital and other bonds by shaking the certainty that people felt existed in their lives and emphasising human mortality. Sonya Rose has argued that there is a contradiction in the way total war 'transforms the everyday in unparalleled ways' but in doing so 'threatens the very unity that the nation is imagined to represent'. ${ }^{17}$ War involved a re-gearing of society and people questioned their beliefs - if killing was acceptable, where did that leave other former taboos, such as divorce? By disrupting the normality of everyday life, war gave a sense of intensity and for some people this intensity combined with other social changes allowed them to take a further step towards relaxing their marital bonds.

\footnotetext{
${ }^{15}$ Arthur Marwick. The Deluge. British Society and the First World War. London: 1965, 111. Marwick's emphasis on social change has been challenged by a number of historians. See, Penny Summerfield. 'Gender and War in the Twentieth Century'. The International History Review 19, no.1 (1997): 4. For New Zealand works which argue in support of continuity rather than change see, D.M. Brosnhan. 'A Woman's Place: Changing Attitudes to the Role of Women in Society during World War II in New Zealand'. MA thesis, University of Canterbury, 1987. Also see Deborah Montgomerie's many publications on women during World War II cited throughout this chapter.

${ }^{16}$ Grayzel, Women and the First World War, 63.

${ }^{17}$ Rose, 'Sex, Citizenship, and the Nation', 1148.
} 


\section{Illustration 3.1}

Cartoon showing large numbers of people entering the Divorce Court, and putting the blame on 'Warriors' Wives Who Went Wrong' and more indirectly on Kaiser Wilhelm.

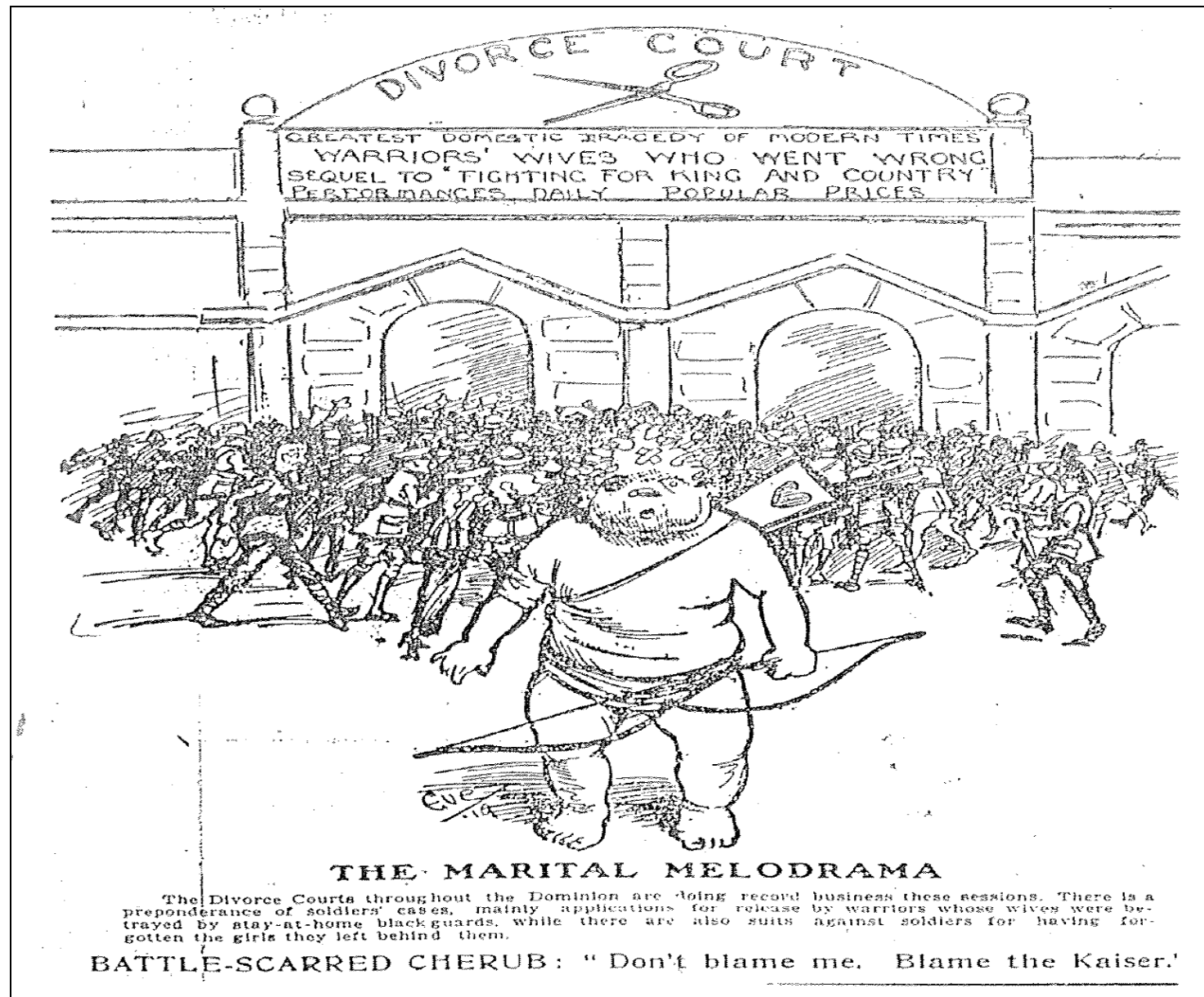

Source: NZT, 7 June 1919.

Newspapers commented on the dramatic increase in the number of divorces during and after war. Truth (Illustration 3.1) made great use of the dramas presented to the divorce courts to fill its pages. Truth itself added to the 'daily drama' by high profile reporting of divorces and promoting an idea of who was to blame. Aware of the increasing numbers of divorces after World War I, it attributed the increase to the war, by blaming soldiers' wives for committing adultery while their husbands fought for Empire. Contrary to Truth's commentary, this was not the cause of the majority of post-World War I divorces. In fact, a reading of Truth's divorce pages from the war period challenges the explanation offered in the cartoon. Regardless of its heading, 'The Fight for Freedom', the coverage of the quarterly divorce sittings in May 1916 does not include a single case involving a serviceman, despite reporting on 21 divorce cases in detail. ${ }^{18}$ Even the issue in which the cartoon was printed on the front page contained 23 reports of divorce, but only eight

18 ““The Fight for Freedom”. Doings in Divorce in the Dominion'. NZT, 27 May 1916. 
involved a husband who had been in the military in some form, and these reports covered cases from all over New Zealand. ${ }^{19}$

By looking at the length of marriages ending in divorce during the two world wars, and using the case files, it is possible to determine how many marriages took place after the outbreak of war. The periods 1914-1921 and 1939-1947 have been focused on to explore the impact of the World Wars on divorce. In World War I of the 237 divorces examined (that is all divorces that occurred between the beginning of the war in August 1914 and the end of 1921) 23 marriages (9.70\%) took place during the war and another two $(0.84 \%)$ took place after November 1918. For the divorce petitions from September 1939 to the end of 1947, 199 (23.30\%) of 854 marriages took place during the war, with another $10(1.17 \%)$ taking place between 16 August 1945 and the end of 1947. Considering all 191 marriages in the database sample that took place during World War I that later ended in divorce, the median length of the marriage from the date of the marriage to the date of the petition was 14.80 years, compared with 12.48 years for the total sample $(\mathrm{N}=2177)$, showing that marriages formed during World War I were less fragile than marriages formed in peacetime. As the database finishes in 1947, it is not possible to calculate comparable data for World War II.

Figure 3.1 shows the length of marriage at the time of decree absolute for the years 1915 to 1921. While there is some variation in the length of marriages from year to year, there is certainly no pattern to suggest marriages of shorter duration made up an increasing proportion of divorces. However, the length of marriage to the time of decree absolute can be misleading as certain grounds such as desertion had an inbuilt separation period of first five years, and later, three years. ${ }^{20}$ Then there was the time it took from filing the petition to issuing the decree absolute. Not all petitioners petitioned for divorce as soon as they could. For example, in July 1944 Dorothy P. told the court, 'my husband was at the last war and prior to going away there had been unhappy differences between us. It had been agreed verbally that we would separate on his return on $28^{\text {th }}$ October 1919 , (it was a

\footnotetext{
19 'A Deluge of Divorce. A Record Rush for Release. Wayward Wives of Warriors Who Went Wrong. Husbands who Proved Hopeless and Heartless Humbugs'. NZT, 7 June 1919.

${ }^{20}$ In many cases petitioners waited longer than the required time period before petitioning for divorce see for example - $W v W$, AAOM/W3265/D1351/1915/ANZ-W which involved a desertion which took place in 1895; $M v M$, AAOM/W3265/D1419/1916/ANZ-W involved a desertion which took place in 1903; and $T v$ $T$, AAOM/W3265/D1263/1914/ANZ-W involved a desertion which took place in 1904.
} 
week after he returned)...There were other women'. ${ }^{21}$ Thus what would appear to be a marriage that ended during World War II was really a marriage that was fragile prior to World War I, and ended after that war.

Figure 3.1

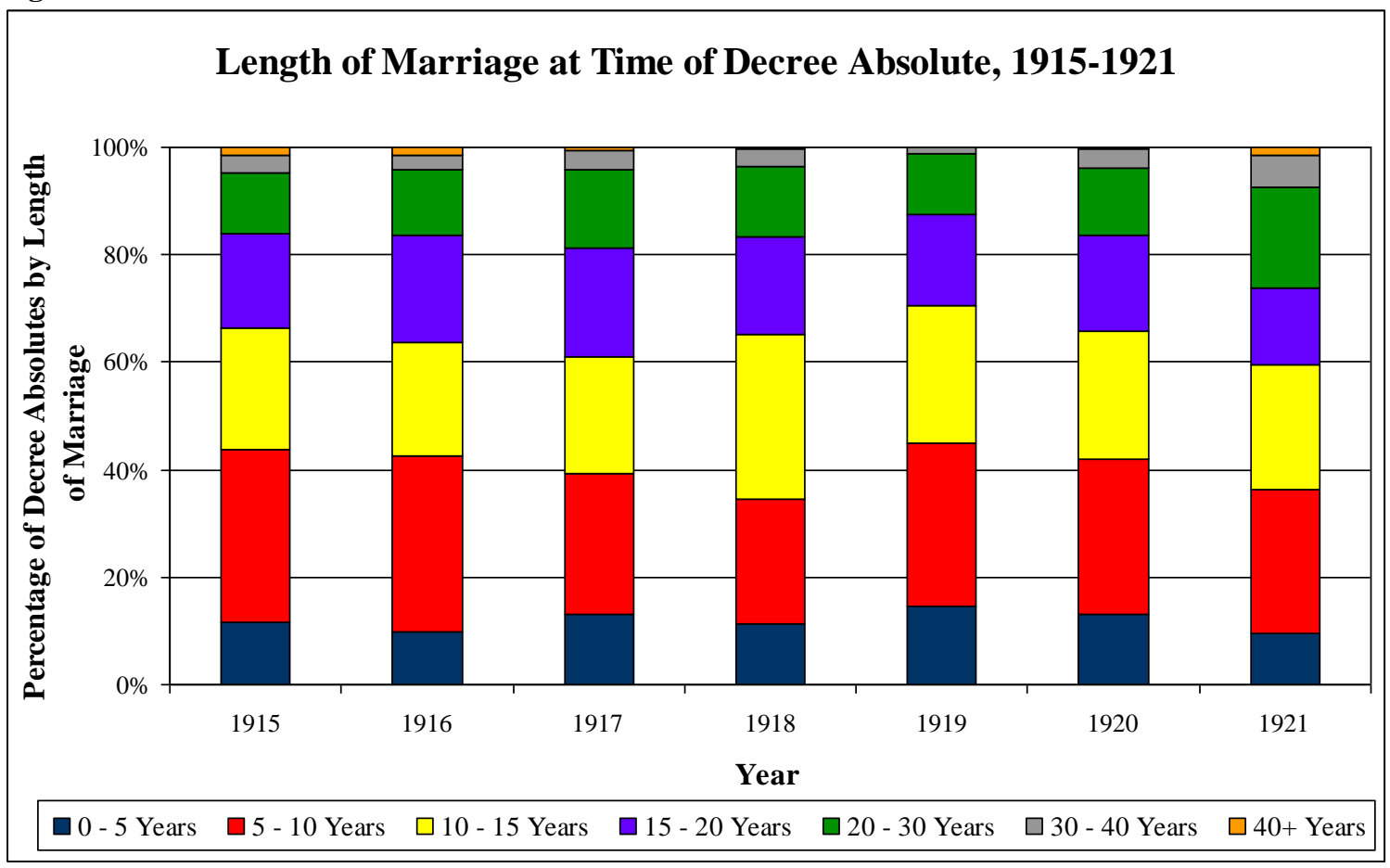

Source: Statistics of New Zealand (data before 1921), Report on Justice Statistics (data from1921).

For World War II (Figure 3.2), there is an increase in the proportion of divorces ending marriages that lasted 10 years or less. Unfortunately there is no national data for 1943 and 1944 so it is not possible to fully explore this trend. At no time in the 1940 s, however, did marriages of five years or less make up more than 20 per cent of all divorces, while 50 per cent of all marriages ending in divorce during this time lasted more than 10 years. Even taking account of the time it took to go through the divorce procedure, these marriages lasted much longer than popular opinion and the media suggested.

${ }^{21} P v P$, AAOM/W3265/D1503/1944/ANZ-W. For another example see $R v R$, AAOM/W3265/D1625/ 1944/ANZ-W, where the husband did not return to New Zealand after World War I but stayed in England. 
Figure 3.2

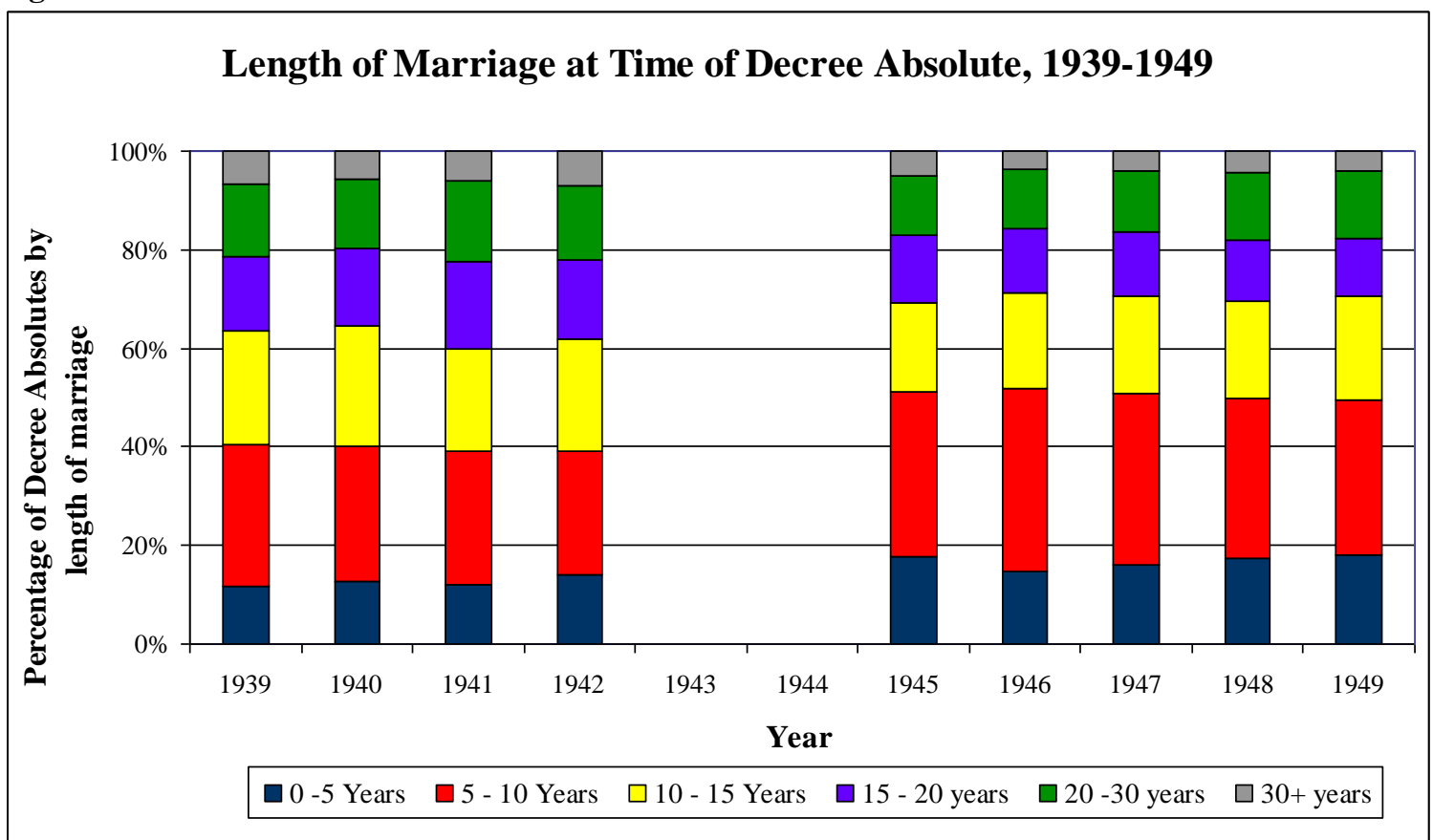

Source: Report on Justice Statistics. Statistics were not collated in such detail in 1943 and 1944 due to the war.

While grounds for divorce have been explored in Chapter Two, the incidence of three grounds - adultery, drunkenness and cruelty and failure to comply with a restitution of conjugal rights - helps explain the connections between war and divorce. After World War I, there was a noticeable increase in the number of petitions from wives on the grounds of drunkenness and cruelty. While these were not the most common grounds for wives to use, the increase was noticeable and deserves further exploration with regards to its possible links to the psychological problems soldiers were believed to have suffered as a result of serving in the conflicts. The period after the war also witnessed a noticeable increase in the proportion of petitions using failure to comply with a restitution of conjugal rights as a ground for divorce and this provoked much criticism, especially from judges who were well aware that this ground was being misused in order to obtain a speedier divorce than using separation of three years or more as a ground. During both wars petitions on the grounds of adultery increased, and this warrants further examination, especially as the assumption by many contemporaries and some historians has been that adultery by wives while their husbands were at war was the primary reason for the increase in the divorce rate during the wars. In World War II, cases where either the husband or the co-respondent were involved in the military were much more likely to be on the ground of adultery than those where there was no military involvement. 
Drunkenness and cruelty, used with increasing frequency during World War I, reached a height just after the war in 1919, before declining markedly from 1927. Six o'clock closing had been introduced in 1917, but alcohol consumption did not decrease until 1922. ${ }^{22}$ Judith Allen in her study on New South Wales has shown that post-World War I psychological reasons were used more to understand domestic violence, and men were less likely to be classified as 'brutes' requiring harsh punishment. ${ }^{23}$ While many men did suffer from a variety of psychological problems after serving in war, in the New Zealand case at least, these problems were more likely to manifest themselves in the 1920s and 1930s rather than immediately postwar, because the government followed a policy of sending single men to the front line. It was from 1917 to 1919 that the ground of drunkenness and cruelty made up an increasing proportion of divorce petitions by wives, but that these men had not served on the front line, and the majority of them had never left New Zealand.

Some men who had other grounds, such as adultery, for divorce, used a restitution of conjugal rights petition before proceeding with a divorce. Raymond C. married his wife Patricia in July 1942 at Wellington (their daughter was born in November 1942) while he was enlisted. He was subsequently sent to Fiji on service in August 1943 and did not return until December 1944. He told the court:

When I came back, when I first arrived, my wife seemed to be alright... we went to her home in Seatoun Rd and I noticed instead of having a double room we had a small single room at the back of the house. My clothes and various possessions were spread over the rest of the house. It seemed from that that nothing had been done to make me welcome....During that time she told me she had met an American serviceman...I asked her if this American serviceman meant anything to her. She said yes. As far as I was concerned, I was out. She just wanted 'Dub' that was his nickname, his name was Browning. During intimacy she often broke down crying and saying, "I just want my Dub." She told me she had lived with Browning on various occasions at her people's home. She told me this on account of her being finished with me, that was her reason. I was very upset at the time about this, but I tried to reason with her and suggest this Browning was possibly not sincere. And I said I'd be prepared to overlook it and resume our married life.

\footnotetext{
${ }^{22}$ Paul J. Christoffel. 'Removing Temptation: New Zealand's Alcohol Restrictions, 1881-2005'. PhD thesis, Victoria University of Wellington, 2006, 188.

${ }^{23}$ Judith Allen. Sex and Secrets. Crimes Involving Australian Women Since 1880. Melbourne: 1990, 13031.
} 
She made difficulties about that, she didn't want to continue married life, she wasn't very keen about intercourse. ${ }^{24}$

Under cross-examination he admitted, 'I believe my wife was unfaithful to me with this American serviceman. Believing that, I am quite sincere in wanting her back, in spite of what's taken place, and in spite of the attachment which still continues'. Patricia C. then told the court,

At the time of my marriage I was 17 years of age. My husband was just over 21. I'd known him quite a while before my marriage, just over 2 years. There had been a friendship between us...I was willing to try and make a go of things, but the way he was bullying me I felt I couldn't. I wouldn't be alone with him when I was away from the family. He was always picking on me, and always knocking me down...I couldn't live with my husband. I suppose we have lived together as much as any wartime marriage, it's not my fault we haven't set up house. ${ }^{25}$

Clearly she had an idea about wartime marriages, and the difficulties involved in such relationships, including housing problems (Patricia had been living with her parents while Raymond was overseas). Whatever was the truth of their situation, Raymond was granted a restitution of conjugal rights which Patricia did not comply with and so he subsequently petitioned for and obtained a divorce, but his wife was granted custody of their daughter (had the divorce been on the ground of adultery the courts would have been less likely to do this).

During the wars, particularly World War II, the newspapers focused on adultery cases, especially those cases involving a wife accused of committing adultery while her husband was serving overseas. New Zealanders who were in the defence forces served a long way from home, making the length of separation greater than for those in Britain or North America. Lawrence Stone, in his study on divorce in England, explained the skyrocketing divorce numbers by 'wartime wifely infidelity'. ${ }^{26}$ Newspaper headlines, such as 'Soldier Let Down By Faithless Wife' were not uncommon, and show the outrage at women not only betraying their husbands but also the war effort. ${ }^{27}$ Marital 'crimes' were considered to be crimes against the national cause. Judges criticised women who sent their husbands 'Dear John' letters while they were fighting, and especially those women who sent such letters to their husbands while they were in prisoner of war camps. ${ }^{28}$ While adultery and

\footnotetext{
${ }^{24} C v C$, AAOM/W3265/D1881/1945/ANZ-W.

${ }^{25} C v C$, AAOM/W3265/D1881/1945/ANZ-W.

${ }^{26}$ Lawrence Stone. Road to Divorce: England 1830-1987. Oxford: 1990, 401.

${ }^{27}$ NZT, 2 May 1945.

28 'Divorce Action', EP, 16 February 1943.
} 
separation did contribute to an increase in the number of divorces, an examination of husbands' occupations during World War I and World War II would suggest that in most divorce cases the men were not even involved in the armed forces, and certainly were not serving soldiers. Of the 237 cases examined from the Wellington Court from August 1914 to the end of 1921 in only 13 cases $(5.49 \%)$ did the husband's occupation either at marriage or at the time of the divorce petition or the co-respondent occupation suggest some involvement in the armed forces. Of the 13 cases, husbands were petitioners in 11 cases and wives in 2 cases. In only 8 of the 237 cases $(3.38 \%)$ was the husband in the armed forces at the time the petition for divorce was filed. This is no doubt reflective of the government policy to enlist single men rather than married men where possible. Clearly explanations for divorce must go beyond those that emphasise the husband's direct involvement in the war, long periods of separation, or the psychological consequences of serving on the frontline.

During World War II a greater percentage of husbands or co-respondents involved in divorce proceedings had at some time been involved in the military, although government policy still privileged those men who were married and had children over single men. ${ }^{29}$ Of the 854 petitions filed between 3 September 1939 and the end of 1947, 168 (19.67\%) involved either a husband or co-respondent who had been involved at some point in the services. In 126 cases $(14.75 \%)$ the husband was in the defence forces at the time the divorce petition was filed. Of the 168 cases in which either the husband or the corespondent had been involved in the military at some point, husbands petitioned for divorce in 107 cases $(63.69 \%)$ and wives in 61 cases $(36.31 \%)$. For the 685 divorce petitions filed between September 1939 and the end of 1947 where there was no involvement in the military, husbands petitioned in 363 cases $(52.99 \%)$ and wives in 322 cases $(47.01 \%)$, showing that husbands who served in the defence forces were significantly more likely to be the petitioner in a divorce case compared with their civilian counterparts.

Although it is unlikely women committed adultery more often than men in wartime, the gender differences in petition grounds suggest that women's adultery or the suspicion of

\footnotetext{
${ }^{29}$ Enlistment for men was voluntary until 18 June 1940. Men who married on or before 1 May 1940 were not conscripted until 1942, and then married men without children were 'targeted' before married fathers, and fathers were ranked according to the number of children they had. Montgomerie, 'Sweethearts, Soldiers, Happy Families', 168.
} 
adultery, was more likely to cause a marriage to end. As Jeffrey Keshen had argued for Canada during World War II, many soldiers 'liberally sowed their wild oats without consequence' and did 'wild things' they would not have normally done, 'believing that they could leave all the consequences behind, ${ }^{30}$ Women did not experience the same degree of freedom or anonymity. ${ }^{31}$ Women were more likely than men to form a lasting relationship during times of war which increased the risks of exposure and the need to 'confess' to their actions. Husbands' visits to brothels and other casual sexual encounters did not create the same threats to the relationship. Given the existing 'double standard', men could be expected to be more agitated by their wife's infidelity than vice-versa. Women were more often 'caught', either through pregnancy, or because they remained in their communities at home, and were therefore subject to surveillance by a variety of people including in-laws, neighbours and friends. ${ }^{32}$ Several examples exist in the divorce files of parents writing to their son about his wife's behaviour, and then giving evidence in court against their daughter-in-law on their son's behalf. ${ }^{33}$

In a few unusual cases the husband actually applied for leave and came home to deal with the divorce himself. For example, Joyce B, who had married in August 1937, wrote to her husband in 1942:

[I] think I've told you I started going out, well I went out, but I came home all wrong, and the consequence is this, that there will be three kids instead of two, the chap's over there some where and I simply hate him, I don't want you to go and do any thing rash dear, but it is better for me to tell you than any one else, I am awfully sorry this has happened, but don't have the kiddies taken off me, as I would sooner see myself dead than that. I was thinking perhaps we could wait till you came home, and talk it over then. ${ }^{34}$

\footnotetext{
${ }^{30}$ Jeffrey A. Keshen. Saints, Sinners and Soldiers. Canada's Second World War. Vancouver: 2004, 127, 131.

${ }^{31}$ Sonya Rose has argued that 'the double standard was alive and well throughout the Second World War'. See, 'The "Sex Question" in Anglo-American Relations in the Second World War'. The International History Review 20, no.4 (1998): 884-903.

${ }^{32}$ Many women kept their affairs secret from their husbands for fear of losing access to their children. For example see Tui Preston's story in Judith Fyfe and Gaylene Preston, eds. War Stories Our Mothers Never Told Us. Auckland: 1995, 46-70. For examples of wives being 'caught' in adultery by becoming pregnant when their husbands were overseas see, $G v G \& G$, AAOM/W3265/D874/1943/ANZ-W; $T v T$, AAOM/W3265/D1057/1943/ANZ-W; $H v H$, AAOM/W3265/D2465/1946/ANZ-W.

${ }^{33}$ For example see, $S \vee S \& M$, AAOM/W3265/D549/1942/ANZ-W; $O v O$, AAOM/W3265/D673/1942/ ANZ-W; $G v G \& G$, AAOM/W3265/D874/1943/ANZ-W; $A v A$, AAOM/W3265/D1529/1944/ANZ-W.

${ }^{34} B v B \& H$, AAOM/W3265/D729/1942/ANZ-W. Letter writing was the primary way in which those in New Zealand kept in touch with those serving overseas. For a history of letter writing during World War II that emphasises its more positive aspects see, Deborah Montgomerie. Love in the Time of War. Letter Writing in the Second World War. Auckland: 2005.
} 
She did not have to wait very long as her husband, Noel B., applied for and was granted compassionate leave to return to New Zealand to obtain a divorce and custody of his two children. This he did. He then had to return to the Middle East and it is not clear who looked after the children. Presumably his family attended to this.

Other soldiers did not find out about their wife's infidelity until they returned home. Alan and Eileen S. had been married in September 1928. Their marriage was very likely precipitated by Eileen's pregnancy, with their first son being born six months after their wedding. In 1941, at the age of 33, Alan enlisted and served in Europe. He spent 17 months in an Italian prisoner of war camp before returning to New Zealand in August 1943. He told the court, 'When I arrived home I found that my wife did not appear very pleased to see me back home. I thought that it was because I had been away so long and things were strange'. ${ }^{35}$ He later discovered she had been having an affair with a man she had known all her life. The case file includes some suggestion that this liaison pre-dated the war. In this case, although war may not have been the catalyst for an extra-marital relationship, the separation may have encouraged the adulterous relationship, causing the marriage to collapse.

Wives were sometimes 'caught' as adulterers when they contracted venereal disease. ${ }^{36}$ George B. told the court in October 1945,

I went overseas in October 1944. When I returned to New Zealand I was medically examined and I was free from disease. I had suspicion of having V.D. and I knew very well I could not have had it. I was sent to the Wellington Hospital for treatment. I was in the Hospital until November 1944 from September 1944. As a result of what happened I questioned my wife on

\footnotetext{
${ }^{35} S v S \& M$, AAOM/W3265/D1209/1943/ANZ-W.

${ }^{36}$ Michael Sturma has argued that in Australia during World War II, it was women who were held responsible for spreading venereal disease and such women were stigmatised and considered deviant. See, 'Public Health and Sexual Morality. Venereal Disease in World War II Australia', in Outrageous! Moral Panics in Australia, eds. Scott Poynting and George Morgan. Hobart: 2007, 197-209. For the British context see, Rose, 'Sex in Anglo-American Relations', 884-903. Likewise, in World War I women, both prostitutes and 'amateurs' were blamed for infecting soldiers. In March 1918 the British government amended the Defence of the Realm Act by adding Regulation 40D which was not dissimilar to the Contagious Diseases Acts of the nineteenth century that feminists had fought hard to have repealed. See, Grayzel, Women and the First World War, 71; Susan R. Grayzel. Women's Identities at War. Gender, Motherhood, and Politics in Britain and France during the First World War. Chapel Hill: 1999, 140-56; Philippa Levine. Prostitution, Race \& Politics. Policing Venereal Disease in the British Empire. New York: 2003, 61-65; for the Australian context see, Judith Smart. "Sex, the State and the "Scarlet Scourge": Gender, Citizenship and Venereal Diseases Regulation in Australia during the Great War'. WHR 7, no.1 (1998): 5-35.
} 
her infidelities to me. I ordered her down to the Wellington Hospital. She was diseased. $^{37}$

Husbands were able to use the medical authorities to obtain personal information about their wives. Another wife, who suffered a miscarriage, was divorced for adultery as medical authorities informed her husband of the situation. Patrick D. told the court in November 1944,

I was first aware of my wife's infidelity after I came home and was stationed at Dargaville. I came [to Wellington] for Xmas holidays and then returned to my station. I had only been back a couple of days when I received a telephone call asking me to come to Wellington fast as my wife was dangerously ill in hospital. I came down as fast as I could and went to the hospital and went to the sister in charge of the ward. She asked me to sign a document for permission to operate on my wife with regard to a miscarriage as she was about 4 months pregnant. I had then been [back in New Zealand] about 6 weeks so I granted the permission. I went to see my wife and I taxed her with adultery'. 38

There was clearly a belief that husbands were entitled to have full knowledge of their wives' medical conditions and medical authorities provided another form of surveillance of wives.

While wives were under increasing surveillance, men who had contracted venereal disease while serving in the armed forces were protected. Venereal disease was evidence of adultery and evidence of venereal disease was therefore very useful in obtaining a divorce. In 1946 an application was made to the Navy to have the medical records of a signalman released to the court and to have the naval surgeon give evidence in court about the man's treatment for venereal disease in 1944. The serviceman concerned had consented to this, presumably as he wanted a divorce as much as his wife did. However, as the naval secretary explained to the Crown solicitor,

the Naval Board feel that it is most undesirable for a Naval Medical Officer to give evidence in Court or for Naval medical records to be produced, as such a practice will tend to undermine the confidence of Naval personnel in Naval Medical Officers, and might lead to personnel concealing the fact that they may be suffering from venereal disease. It is most necessary in the public interest that members of the Forces suffering from this disease should disclose this to the medical officers.... Notwithstanding the fact that the rating in this case has authorised the Naval Medical Officer to produce the medical records and appear in Court to give evidence against him, the Naval Members of the Naval Board are still of the opinion that privilege should be claimed, and that

\footnotetext{
${ }^{37} B \vee B$, AAOM/W3265/D1945/1945/ANZ-W.

${ }^{38} D \vee D \& M$, AAOM/W3265/D1307/1944/ANZ-W.
} 
the records and oral evidence of the medical officers should not be made available for Court proceedings. ${ }^{39}$

Once again, men's sexual behaviour was actively protected by the government whereas women's behaviour was subjected to many different forms of surveillance and this made it much easier for women to be accused of adultery than husbands.

While it is difficult to get figures on widespread changes in civilian sexual behaviour, 'shotgun' marriages and the illegitimacy rates do offer some insight. Using the Wellington sample, between August 1914 and the end of 1921, 43 of the 237 cases $(18.14 \%)$ involved the birth of a child within the first seven months of marriage. Between September 1939 and the end of 1947, 169 of the 854 divorce cases (19.79\%) involved a 'shotgun' marriage. This issue is explored more fully in Chapter Seven, but these figures do not distinguish the war periods from peacetime - in fact marriages formed during wartime were slightly less likely to have involved a 'shotgun' wedding than those formed during peacetime. In 18919.38 illegitimate children were born for every 1000 women aged between 15 and 45; in 1926 the figure was 9.92 and in 1936 it was 6.71. In 1945 the rate was 11 children per 1000 fertile women. ${ }^{40}$ This again shows some change, but the drop in the rate during the 1930s is more remarkable than the rate at the end of the war. However, an increase in the use of contraception and possibly abortion may have hidden significant increases in the practice of pre-marital sex. ${ }^{41}$

More generally, Richard Joblin has argued that Truth's articles in the post-World War I era on contemporary social behaviour suggest that many New Zealanders were concerned with 'a widespread fear of falling standards of sexual behaviour'. Joblin claims that Truth '[i]n its concern with venereal disease, it created a new folk devil by introducing the word "flapper". ${ }^{42}$ Modern dress and the cinema became associated with decadence'. ${ }^{43}$ These

\footnotetext{
${ }^{39}$ Naval Secretary to the Crown Solicitor, 25 March 1946, AAYT/8490/NI/18/1/18/ ANZ-W.

${ }^{40}$ Deborah Montgomerie. The Women's War. Auckland: 2001, 157.

${ }^{41}$ Ibid., 158.

${ }^{42}$ New Zealand soldiers had one of the highest rates of venereal diseases of the British imperial forces. There was also a very high rate of infection during World War II. See, Antje Kampf. 'Controlling Male Sexuality: Combating Venereal Disease in the New Zealand Military during Two World Wars'. JHS 17, no.2 (2008): 235-58.

${ }^{43}$ Richard S. L. Joblin. 'The Breath of Scandal. New Zealand Truth and Interwar Society, 1918-1939'. MA thesis, University of Canterbury, 1990, 184-85. Grayzel has noted similar concerns. Women's increased consumption of cigarettes and alcohol during World War I was linked to immorality and sex. As well, there were concerns about disorderly or aggressive women and also 'sexual perversity'. Grayzel cites the Pemberton Billing scandal in Britain in 1918 as an example of this. See, Grayzel, Women and the First
} 
ideas echo the claims Arthur Marwick has made, discussed earlier in the chapter. Claire Gooder, writing about sex education in New Zealand during World War II has emphasised the centrality of marriage to sex education during this time, and the importance of maintaining 'social stability'. ${ }^{44}$ She argues that sex educators considered war to be an 'aberrant time', and there was a focus on reinforcing the importance of premarital chastity. ${ }^{45}$ Dr Clara Lee, and then Dr Agnes Bennett, were employed to deliver lectures to servicewomen on sex education. ${ }^{46}$ This growing public concern with sexual behaviour indicates a greater willingness on the part of many individuals to explore their sexuality, sometimes outside of marriage. Writing about World War I, Susan Grayzel has described the irreversible changes relating to sexuality: 'The genie - an allegedly new and arguably more widespread awareness of a more active sexuality for women - could not be put back in the bottle'. ${ }^{47}$ This greater willingness to challenge accepted standards of sexual behaviour contributed to the increasing incidence of divorce.

Women who formed relationships with American soldiers, based in New Zealand from 1942 to 1944 (primarily in Wellington and Auckland), were considered to be 'indulging in sexual sedition,' by many New Zealand men, particularly those in the defence forces, despite the fact that the Americans were Allies. ${ }^{48}$ The American presence provoked

World War, 65. For other concerns about British women's morality during World War I see, Braybon and Summerfield, 107-13.

${ }^{44}$ Claire Gooder. 'A History of Sex Education in New Zealand, 1939-1985'. PhD thesis, University of Auckland, 2010, 24-76.

${ }^{45}$ Ibid., 31, 49-50.

${ }^{46}$ Ibid., 52-63; Sandra Coney. 'The Affair of Dr Clara Lee', in Standing in the Sunshine. A History of New Zealand Women since they Won the Vote, ed. Sandra Coney. Auckland: 1993, 307. Lee was dismissed after distributing a questionnaire to servicewomen asking about their sexual knowledge and experiences. The questionnaire acknowledged the possibility that women may have engaged in pre-marital sex. Bennett toured New Zealand giving lectures from mid-November 1943 until early 1944. After the incident with Lee, Bennett was required to submit her lecture notes in advance for approval. Gooder notes that many of the servicewomen complained about Bennett's lectures and considered the 71-year-old Bennett to be 'out of touch' (Gooder, 63). Bennett, however, had worked in military hospitals in Cairo and Serbia during World War I, and so had first-hand knowledge of the effect of wartime conditions on sexual behaviour. Unlike Lee, however, Bennett never married. See Beryl Hughes. 'Agnes Bennett, 1872-1960', in The Book of New Zealand Women. Ko Kui Me Te Kaupapa, eds. Charlotte Macdonald, et al. Wellington: 1991, 78-81.

${ }^{47}$ Grayzel, Women and the First World War, 78.

${ }^{48}$ Deborah Montgomerie. The Women's War. 164. For examples of such relationships see, $B v B$, AAOM/W3265/D2213/1945/ANZ-W; $T v T \& L$, AAOM/W3265/D2277/1945/ANZ-W. For a history of the American presence in New Zealand see, Deborah Montgomerie. 'GI Joe Down Under. American Infantrymen in New Zealand during World War II'. NZJH 34, no.2 (2000): 262-76; Jock Phillips with Ellen Ellis. Brief Encounter. American Forces and the New Zealand People 1942-1945. Wellington: 1992; Nancy Taylor. The New Zealand People at War: The Home Front. Vol. I. Wellington: 1986, 621-61; Jane Tolerton. 'Wartime Romances and their Consequences', in Standing in the Sunshine. A History of New Zealand Women since they Won the Vote, ed. Sandra Coney. Auckland: 1993, 316-318. While there was much concern in Britain about white British women forming relationships with black American soldiers, the divorce files provide no evidence of this occurring in New Zealand. For the British situation see Rose, 
similar sentiments in Australia and Britain, and Americans were viewed as a threat to British masculinity. ${ }^{49}$ American soldiers were seen as exotic and romantic in their uniforms. Their accents reminded New Zealand women of Hollywood movie stars and women's perception of American men as lovers, created by watching Hollywood films, further constructed the men as sex objects. ${ }^{50}$ They were also better paid, and 'brought a new style of dating' which involved giving gifts such as chocolates, flowers, silk stockings, as well as taxi rides and meals in restaurants, which created resentment on the part of local men. ${ }^{51}$ Adding to this situation, the interwar years had seen an increasing sexualisation of women, with sexual pleasure being seen as every woman's right, and sexual attractiveness being available to all. ${ }^{52}$ The 'sexually active woman was portrayed as a symbol and cause of the social and moral chaos unleashed by the war, in the same way that the economically active woman had been perceived during the depression - they were signs of their disordered times'.53 Again, perceptions of women's sexuality provided the gauge for society, not men's sexuality.

The romantic, passionate feelings that American soldiers evoked in some women are seen in a letter Daphne B. wrote to her husband in September 1943. She wrote,

The way I love him is quite different from the feeling I had for you... It is a love I didn't know existing, and I am not going to pass it by...You think the children will keep me, they won't. As much as I love them, my other love is now bigger. I can have more children and I will, with or without a divorce. They won't be the first to be born out of wedlock. So you see I am going to have my American with or without a divorce and that is all I want...You can't live here because the rent is being paid in my name. You can live at your

\footnotetext{
'Sex, Citizenship, and the Nation', 1152-1159; Sonya O. Rose. 'Girls and GIs: Race, Sex and Diplomacy in Second World War Britain'. The International History Review 19, no.1 (1997): 146-60; For the Australian situation see, Kay Saunders. 'In a Cloud of Lust: Black GIs and Sex in World War II', in Gender and War. Australians at War in the Twentieth Century, eds. Joy Damousi and Marilyn Lake. Cambridge: 1995, 17890 .

${ }^{49}$ Goodman, 'Patriotic Femininity', 288. See also, John Costello. Love, Sex and War. Changing Values, 1939-45. London: 1985, 309-31; Michael Sturma. 'Loving the Alien; The Underside of Relations Between American Servicemen and Australian Women in Queensland, 1942-1945'. Journal of Australian Studies 13, no.24 (1989): 3-17; Lyn Finch. 'Consuming Passions: Romance and Consumerism during World War II', in Gender and War. Australians at War in the Twentieth Century, eds. Joy Damousi and Marilyn Lake. Cambridge: 1995, 105-16.

${ }^{50}$ Marilyn Lake. 'The Desire for a Yank: Sexual Relations between Australian Women and American Servicemen during World War II'. JHS 2, no.4 (1992): 629. Also see, Erica Buxton. 'Realigning Dreams. The Marriages of New Zealand Women and American Servicemen during World War Two'. BA(Hons) research essay, University of Otago, 2010, 13-23; Leanne McCormick. “'One Yank and They're Off”: Interaction between U.S. Troops and Northern Irish Women, 1942-1945'. JHS 15, no.2 (2006): 228-57.

${ }^{51}$ Marilyn Lake and Joy Damousi. 'Warfare, History and Gender', in Gender and War. Australians at War in the Twentieth Century, eds. Marilyn Lake and Joy Damousi. Cambridge: 1995, 9.

${ }^{52}$ Patricia Grimshaw, et al. Creating a Nation, 1788-1990. Ringwood: 1994, 262.

53 Ibid.
} 
mother's because I will never live with you again. I wouldn't be able to manage two husbands and that is what my American is going to be from now on, my husband... By the time you get this I will be what a lot of people call a harlot. But I know I won't feel like one, because it will be with the man I love and that makes a difference. ${ }^{54}$

Not only does the letter demonstrate the fact the wives were prepared to leave their marriages and their children in order to 'follow their hearts', they were prepared to assert their rights as individual citizens with Daphne telling her husband that she had control of the house as the tenancy was in her name. Her letter shows an increasing willingness to openly flout sexual mores, but also provides a justification for such behaviour - it was acceptable to Daphne to live with a man who was not her husband because she loved him, and she considered him to be her husband, even if the relationship was not legally sanctioned.

Many New Zealand men who served in World War II were concerned about their wives' behaviour while they were away, and in particular they were concerned about the presence of American soldiers in New Zealand. British soldiers had many similar concerns, but depending on the theatre of war, it usually was easier for them to return home than it was for the New Zealand servicemen. It has been claimed the fears British servicemen had about their wives' fidelity 'was thought to be a significant factor in causing neurosis, unofficial absence and a reduction in the overall commitment and efficiency of the war effort' ${ }^{55}$ It seems there were similar concerns in New Zealand, but at the same time this did not stop observant family, friends and neighbours contacting soldiers and letting them know what their wife was doing and with whom she was associating. Often the army would become involved if a soldier wanted to have his wife's allotment cut because he suspected her of adultery, and sometimes the police would become involved in gathering evidence for soldiers, or information acquired by the police in relation to other issues, such as investigating prostitution, would be used by husbands as well. In late 1942 special 'vice squads' were formed in Wellington and Auckland and they targeted hotels, brothels and boarding houses which let rooms. ${ }^{56}$

\footnotetext{
${ }^{54} B v B \& P$, AAOM/W3265/D1189/1943/ANZ-W. For another example of a man petitioning for divorce on the ground of adultery after his wife had an affair with an American see, $B v B \& H$, AAOM/W3265/ D861/1943/ANZ-W.

${ }^{55}$ Goodman, 'Patriotic Femininity', 288.

${ }^{56}$ Montgomerie, The Women's War, 156.
} 
Some American soldiers tried to argue that they were protected by international law and could not be served with papers relating to divorce in New Zealand when they were named as a co-respondent. The Crown Solicitor investigated this issue in response to legal enquiries, and determined that 'no regulation statute law or rule of common law (including such principles of international law as are incorporated in the common law) exists in New Zealand which would have the effect of exempting from the civil jurisdiction of the Supreme Court in divorce members of the United States Armed Forces at present on duty in New Zealand' ${ }^{57}$ However, often by the time New Zealand husbands had returned home, the American soldier had left the country, so while the American would be named in the petition (excluding situations where wives refused to provide names) they were not named as a co-respondent, and so papers did not have to be served. This meant that they could not be made to pay costs or damages.

A number of legal, as well as social issues arose out of the large number of New Zealanders marrying non-New Zealanders during World Wars I and II. In 1919 the divorce law was amended to allow women who were 'natural-born British subjects' married to a man of enemy origin to petition for divorce in New Zealand even if her husband was domiciled overseas. As well, such wives were entitled to the custody of any children of the marriage. ${ }^{58}$ Most New Zealand women who married a foreigner during World War II, married American servicemen, while most New Zealand men married British women (who were not foreigners as it was only after World War II that separate Dominion citizenship was created, meaning at this time New Zealanders were British citizens, as were Canadians and Australians). ${ }^{59}$ Further, there was the issue of New Zealanders divorcing while the husband was serving overseas, and the complications arising with the need to serve papers on the respondent, and also the status of aliens, and in particular enemy aliens in New Zealand who wanted to obtain a divorce under New Zealand legislation. The New Zealand government, and at times the judiciary, were involved in finding solutions to the variety of marital problems created during World War

\footnotetext{
${ }^{57}$ Crown Solicitor to the Under-Secretary, Justice, 10 November 1942, ACGS/16211/J1/W1190/box 69/1942/35/66/ANZ-W.

${ }^{58}$ Divorce and Matrimonial Causes Amendment Act 1919 (10 Geo V. 1919 No. 53). See also, 'Causes for Divorce. Important Amending Bill Wives of Enemy Aliens'. EP, 4 October 1919.

${ }^{59}$ A small number of New Zealand men married Italian, Greek and French women. See Gabrielle Fortune. “"Mr Jones' Wives": War Brides, Marriage, Immigration and Identity Formation'. WHR 15, no.4 (2006): 587-99. See also Gabrielle Fortune. “'Mr Jones' Wives” World War II Brides of New Zealand Servicemen'. $\mathrm{PhD}$ thesis, University of Auckland, 2005.
} 
II. There was a general consensus assistance should be provided and wartime marriages should be easier to dissolve than those formed under 'normal' circumstances. ${ }^{60}$

While Gabrielle Fortune has argued that it was changes in legislation after World War I, and during World War II that led to the increase in the divorce rate, she does not take into account the number of divorces that made use of these new grounds. ${ }^{61}$ Although such changes played a part, they were not the primary reason. During World War II the New Zealand government, along with other governments (especially Britain) had to alter, and at times relax, the rules and legislation governing divorce. Many people's circumstances did not allow them to divorce, for reasons of domicile, citizenship or because they had married a foreign national. Unlike other changes to the laws, which were opposed by a segment of society, as they were believed to encourage divorce, the changes to the divorce law during World War II were seen as necessary, and at times patriotic. Comparatively few litigants, however, used these new grounds.

In 1946 the Matrimonial Causes (Wartime Marriages) Emergency Regulations were gazetted covering situations where one spouse was domiciled outside of New Zealand prior to the marriage. These Regulations were confirmed by the Matrimonial Causes (War Marriages) Act $1947 .{ }^{62}$ The Supreme Court was given jurisdiction to hear cases where a wife married during the war to a person domiciled abroad if the wife was domiciled in New Zealand up to the time of the marriage. There was also recognition of decrees of other British countries granted under similar extended jurisdiction and recognition is invited abroad of decrees pronounced under this legislation in New Zealand. This was necessary as on marriage a wife lost her own domicile and was deemed to have her husband's domicile, and in general it was necessary to petition for divorce in the jurisdiction in which one was domiciled. The problems surrounding this one legal identity for married couples were discussed in Chapter One. The regulations also recognised in New Zealand, American decrees of divorce and it allowed New Zealand women married to men, engaged in any capacity connected with the war, to petition on grounds of desertion without having to wait for the period of three years to pass. A man who had

\footnotetext{
${ }^{60}$ See 'An American Serviceman's Divorce'. NZLJ, 17 December 1946, 318.

${ }^{61}$ Fortune. “'Mr Jones' Wives” World War II Brides of New Zealand Servicemen', 237.

${ }^{62}$ The Attorney-General, Rex Mason gave a detailed explanation of the bill when he moved that the bill be committed after having gone before the Statutes Revision Committee. He and other MPs spoke of the difficulties faced by New Zealand 'girls' who had married American servicemen. See NZPD, 277, 5 August 1947, 130-34.
} 
married overseas while he was engaged in a capacity connected to the war was able to divorce his wife after six months desertion, rather than three years. The regulations, and the subsequent act, were limited to marriages that had taken place after 3 September $1939 .{ }^{63}$

It was not just men who received 'Dear John' letters. Some women were sent 'Dear Jane' as well. Nola Z. had married her American husband in October 1943, and he left New Zealand the following month on service. In January 1945 she received a letter stating,

I am not sending for you. I mean now or ever. Marrying you was a big mistake for I don't love you and I didn't then. I was just half batty from being away from everything so long and thinking about going back into action again... Since I've been back I've been running around with women. I've been going home with them and staying all night. Every liberty I go get drunk and shack up with some woman. When I was home on furlough I was living with a bunch of women. My father knew it. They didn't like it but I couldn't stay at home.... This country is a roaring hell. And you'd be lost in it I know. I've seen some of the women that come here from Down Under. From what I've seen since I got back I couldn't trust a woman as far as I could throw a bull by the tail. ${ }^{64}$

It was not uncommon for New Zealand women who married Americans to receive such a letter and they faced many difficulties in obtaining a divorce, or maintenance if they had a child.

By 1944 it became clear that a number of marriages that had been formed between New Zealand women and American men would not last and many women were left in New Zealand, sometimes with a child, without any support or knowledge of where their husband was. ${ }^{65}$ Further, they had lost their New Zealand domicile and were unable to petition for divorce until they were separated for three years. Often their husbands divorced them in America, but they received no notice of the case, and even if they did it was very expensive and difficult to defend such a case, or to claim maintenance for themselves or their children. Several groups, including the Society for the Protection of Women and Children, and the New Zealand Eagle Club (an organisation of New Zealand women married to Americans) raised concerns with the government about this situation. ${ }^{66}$

\footnotetext{
63 'Divorce Law. Important Changes. Wartime Marriage'. EP, 11 May 1946.

${ }^{64} Z v Z$, AAOM/W3265/D2701/1946/ANZ-W. For other similar situations see, $K v K$, AAOM/W3265/ D2797/1946/ANZ-W; $S v S$, AAOM/W3265/D2869/1946/ANZ-W.

${ }^{65}$ For examples see $C v C$, AAOM/W3265/D2597/1946/ANZ-W; $M v M$, AAOM/W3265/D117/1947/ ANZ-W. For further details see Buxton, 58-64.

66 'Easy Divorces. Conference Concerned. Protection Societies Meet'. EP, 6 December 1946.
} 
This led the Prime Minister, Peter Fraser, to state in 1946 that the Under-Secretary of Justice would assist women who found themselves in such a situation and if necessary the New Zealand Minister in Washington DC would also provide help, and in some cases financial assistance was provided. ${ }^{67}$

Some women were not 'abandoned' in New Zealand, but went to the United States to live with their husbands. One such woman, Catherine Novak, who had married Johnny Young, an American, at the Registry Office in Palmerston North on 21 April 1943, arrived in the United States on 23 February 1944. She explained in her letter to the New Zealand Legation in Washington DC that,

I knew something was terribly wrong as soon as I saw him and three days later he asked if I wanted a divorce. I most certainly did not and after talking it over, he said he'd try and see things through....For six weeks I tried to forget what was going on and looked after him and the house the same as always, but we were never at ease with each other and our nerves began to give way.... I said I'd give him his divorce, but I wanted alimony. He didn't want to give me any but I said "No alimony, no divorce" and I won. On $20^{\text {th }}$ April, 1944, I left him and on $21^{\text {st }}$ April, 1944, I took up residence in Reno. I took a job there to keep myself and pay for the divorce, which cost $\$ 194$ and some cents. While in Reno, I received in June, the last allotment of \$100. On June $15^{\text {th }}$, I obtained my divorce and the Court granted $\$ 30$ per month alimony until I remarry, or die, the first payment to begin July $1^{\text {st }}, 1944$. It is now $1^{\text {st }}$ August, and I've not received my first payment.... No one is looking after me and I've no relations here. I'm going to stay where I am until I can get my Gov. job and then I'll work until I can get enough money to get transportation back home. ${ }^{68}$

Women who had married Americans tended to be young, and most had never left New Zealand before, so to find themselves stuck on the other side of the world would have been a very stressful situation, but perhaps they also experienced a degree of autonomy and freedom that they would not have otherwise had. ${ }^{69}$

While, there was more public sympathy for men whose wives committed adultery than women who were deserted by their husbands, there was less financial support provided to soldiers to divorce their adulterous wives compared with the New Zealand women who divorced their American husbands. In July 1943, the Secretary of the Canterbury

\footnotetext{
67 'Divorce Actions. By U.S. Servicemen'. EP, 19 September 1946; Head of Prime Minister's Office to the Under-Secretary for Justice, 3 September 1946, ACGS/16211/J1/W1190/1944/42/9/ANZ-W.

${ }^{68}$ Catherine Young to First Secretary, New Zealand Legation, Washington DC, 1 August 1944, ACGS/16211/J1/W1190/1944/42/9/ANZ-W.

${ }^{69}$ For examples of the experiences of British women who married American servicemen see, David Reynolds. Rich Relations. The American Occupation of Britain, 1942-1945. London: 1995, 413-28.
} 
Provincial Patriotic Council wrote to the Minister of Defence, Frederick Jones, about assisting soldiers who wanted to divorce their wives on the ground of adultery. He wrote, 'Assistance of this nature hardly comes within the scope of patriotic funds, but on the other hand it does not seem equitable that a soldier should be required to retain his affiliation and maintain a woman who has been unfaithful to him while he has been away in his country's service. It is suggested that the situation is almost certainly one which has arisen through the soldier's war service'. ${ }^{70}$ As well, William Denham, the MP for Invercargill, had raised similar concerns. Frederick Jones wrote to him to explain the Army was not able to provide legal services for soldiers, nor fund any litigation, but 'since the beginning of the war legal practitioners have, in accordance with arrangements made with the Law Societies, attended at the camps in New Zealand and given free legal assistance to soldiers'. ${ }^{71}$ Those soldiers who met the requirements could sue for divorce in forma pauperis but most would not have qualified so would have had to find the money elsewhere. Also, they had to provide the court with security to cover their wives' legal costs and they were expected to pay for these costs regardless of the outcome of a trial. That is to say, even when a wife was found guilty of adultery it was her husband who had to pay her legal costs if she chose to defend the case, and then he could attempt to have the co-respondent pay him these costs, but when the co-respondent was an American it was very difficult to recover costs, especially if he had left the jurisdiction.

Some men, who had married while serving overseas, also had marital problems when their non-New Zealand wives arrived in the country. In September 1949, Stuart C. told the court that he had married his wife in England during the war. She arrived in New Zealand in January 1946 and their child was born in March. He said,

She left in October 1946, less than 9 months after she arrived. I have not seen her since she left. She took the baby with her. When she came to New Zealand she was always dissatisfied and complaining about New Zealand and New Zealanders. During the time we lived together in New Zealand she left my home on numerous occasions - each time I went and got her back. ${ }^{72}$

Also in the file was a letter from his wife to the judge dated January 1950. She claimed that she had only returned to England for six months and in that time her husband had

\footnotetext{
${ }^{70}$ Acting Hon. Secretary of the Canterbury Provincial Patriotic Council to The Minister of Defence, 30 July 1943, AAYS/8638/AD1/320/4/6/ANZ-W.

${ }^{71}$ Minister of Defence to W. M. C. Denham, 23 October 1943, AAYS/8638/AD1/320/4/6/ANZ-W.

${ }^{72} C v C$, AAOM/W3265/D305/1947/ANZ-W. Another soldier's wife never even made it to New Zealand. He received a letter from his Canadian wife stating that she had had a baby to another man. See, $L v L$, AAOM/W3265/D2833/1946/ANZ-W.
} 
agreed to establish a home for her and their baby. 'You may think dear sir that our marriage was just another war-time marriage, and that we like some just rushed into such, but I can assure you that my husband must have been very sure as he married me twice, the first marriage was January $12^{\text {th }}$ at 10.30 at a registry office, my husband had to then go away and it was agreed between us by letter that when he came home at the end of April we would re-marry at church, we did just that on May $5^{\text {th }} 1945,{ }^{73}$ It seems that their re-affirmation of their marital vows did not provide any extra strength to their marriage. The case also highlights the difficulties war brides faced. They married their husbands in their home countries and usually agreed to move to their husband's home country after the war, without ever having visited it, and often having no knowledge of what it was like.

Finally, there were a number of cases involving enemy aliens who were trying to obtain a divorce through the New Zealand courts. In 1941, the right of an Italian man, who had been interned since the entry of Italy into the war, to petition for divorce was upheld by Justice Ostler. He told the court that 'there was nothing to show that the petitioner was hostile to New Zealand, but even if he were hostile the laws of the country were not so illiberal as to deprive him of his rights' ${ }^{74}$ In another case in the same year, a German woman who had been living in New Zealand since February 1938, asked the court to dispense with service of papers, as her husband who was German, was in a concentration camp in Germany as a result of his Communistic activities, and it was next to impossible to serve papers on him there. Justice Johnston dismissed her application and concluded, 'that for the purposes of the divorce proceedings the woman could be regarded as an alien friend, but that it was not a case where service should be dispensed with'. ${ }^{75}$

One reason offered for increasing rates of divorce during wartime, is that women had increasing opportunities to earn an income. New Zealand women, however, did not enter the paid workforce during the wars to the same degree that British women did. Melanie Nolan has shown that while women's participation in paid employment did increase during World War I, the increase between 1911 and 1921 (26.42 per cent, from 90,295 to 114,152) was not as great as it was between 1901 and 1911 (43.21 per cent, from 63,049

\footnotetext{
${ }^{73}$ C v C, AAOM/W3265/D305/1947/ANZ-W.

74 'The Right to Sue. Interned Italian. Upheld By Court'. EP, 15 December 1941.

75 'Alien at Law. Husband in Germany. Difficulty of Service. Papers in Divorce'. EP, 16 September 1941.
} 
to 90,295$).{ }^{76}$ During World War II, while women remained in the 'female sector of the labour market' their numbers did increase with the National Service Department, with 236,000 women in paid employment in $1943 .{ }^{77}$ Industrial conscription of women was introduced, comparatively late in New Zealand, in March 1942 and there was no military conscription of women. ${ }^{78}$ It is true that at the end of both of the wars, most married women were not in paid employment. Most women did not state whether they were in paid employment or not on their divorce petition, but individual situations suggest that having secure employment that paid a decent salary was a factor in women deciding not to return to their husbands. Mona A. established herself as a manager of a grocery store while her husband was serving overseas. When he returned in December 1944, Henry A. told the court, 'My wife did not meet me...I saw her and asked her why she didn't meet me. She said she had ceased to have any affection for me and ceased to live with me'. ${ }^{79}$ Henry offered to buy a country grocery store so that his wife could continue in her line of work but she refused. Had Mona not had a secure job she may have been less likely to leave Henry. In another situation, a war bride from Britain, who was unhappy with living with her husband at Tolaga Bay, was able to find permanent employment in Wellington and moved there after her husband objected to her finding work near their home. ${ }^{80}$ This woman was able to take advantage of the increasing acceptability of women being in paid employment in the post-World War II era. More generally, the high earnings of men and

\footnotetext{
${ }^{76}$ Melanie Nolan. "Keeping New Zealand Home Fires Burning”: Gender, Welfare and the First World War', in New Zealand's Great War. New Zealand, the Allies and the First World War, eds. John Crawford and Ian McGibbon. Auckland: 2007, 495. Susan Grayzel has written about the tension in Britain and France during World War I over needing women to take over men's jobs in the paid workforce and concerns about replenishing the population and encouraging women to have more children. See, Grayzel, Women's Identities at War, 103-20.

${ }^{77}$ Deborah Montgomerie. 'Reassessing Rosie: World War II, New Zealand Women and the Iconography of Femininity'. $G \& H$ 8, no.1 (1996): 110-11. See also, Deborah Montgomerie. 'The Limitations of Wartime Change. Women War Workers in New Zealand'. NZJH 23, no.1 (1989): 68-86; Deborah A. Montgomerie. 'A Personal Affair Between Me and Hitler? Public Attitudes to Women's Paid Work in New Zealand during World War II'. MA thesis, University of Auckland, 1986. Farm work was one of the few areas where women were seen to be replacing men, although Montgomerie has argued that in reality the Land Service scheme did little to increase the number of women in agricultural employment. See, Deborah Montgomerie. 'Men's Jobs and Women's Work: The New Zealand Women's land Service in World War II'. Agricultural History 63, no.3 (1989): 1-13.

${ }^{78}$ Montgomerie. 'Sweethearts, Soldiers, Happy Families', 163. Industrial conscription of women was limited to childless women aged 18-40. For an overview of women's employment during the war see, Nancy M. Taylor. The New Zealand People at War: The Home Front. Vol. II. Wellington: 1986, 674-84. For a brief overview of women who did enlist see, Sandra Coney. 'In Uniform', in Standing in the Sunshine. A History of New Zealand Women since they Won the Vote, ed. Sandra Coney. Auckland: 1993, 319.

${ }^{79} A \vee A$, AAOM/W3265/D1717/1944/ANZ-W.

${ }^{80} K v K$, AAOM/W3265/D81/1947/ANZ-W.
} 
women civilian workers during the war meant that divorce became more affordable to many. ${ }^{81}$

Other relationships dissolved because one of the spouses was simply not interested in being married. In November 1942 Victoria V. received a letter from her husband Peter which read, 'As you know I have always been a bit of a wanderer and looking back now I can't understand why we ever got married....I know you will think I have no honour but it is useless carrying on together any longer. So wishing you all the best of luck in the future. I will say adieu'. ${ }^{82}$ The relationship did not end because of a major dispute between the couple, but because Peter was not interested in being married. Some husbands were unhappy when their wives acted too independently. In 1943 one husband complained, 'I noticed a change in my wife. She had her own ideas about whom she should go out with. Ultimately, although we lived together for a time, she left...She preferred her own friends and freedom to being married and living with me'. ${ }^{83}$ While many saw being married as better than being single, others were not convinced of the advantages of marriage and increasingly during World War II some people were prepared to leave their marriages in search of greater freedoms.

The churches were also very much aware of a change in people's behaviour after the wars. Bishop Thomas Sprott, delivering the presidential address at the opening of the Anglican Synod in 1920, acknowledged the general social unrest after the war and claimed, 'there can be no doubt that the war rudely shook, perhaps shattered, the faith of many people in God'. ${ }^{84}$ One example of the problem highlighted by Bishop Sprott was the decline in religious observance. The Methodist church, which traditionally had enjoyed very high rates of church attendance, 'became acutely aware of a decline in levels of participation in its church life... and found it difficult to comprehend the concept of "nominal Methodists"“. ${ }^{85}$ There was little the churches could do to halt this waning interest in church life.

\footnotetext{
${ }^{81}$ Rowntree and Carrier, 203.

${ }^{82} V v V$, AAOM/W3265/D829/1942/ANZ-W.

${ }^{83} H v H$, AAOM/W3265/D1289/1944/ANZ-W.

84 “'Irreligious Drift” Problems of To-day. World After the War'. EP, 6 July 1920.

${ }^{85}$ Allan K. Davidson and Peter J. Lineham. Transplanted Christianity: Documents Illustrating Aspects of New Zealand Church History. $3^{\text {rd }}$ ed. Palmerston North: 1995, 239.
} 
The churches suffered similar problems during World War II, but the issue of the war was confronted more directly than it had been during World War I. For example, in May 1941 the Evening Post announced that Rev. Newell would be speaking at The Terrace Congregational Church on the topic of war and religion as it was a theme that is deeply troubling the minds of many persons at the present time'. ${ }^{86}$ Similarly, in February 1942 the president of the Conference of the Methodist Church of New Zealand claimed, 'It is right to fight; for it is only by fighting that we can restrain the evil that seems to be spreading like some awful plague across the world', making the official position of the Methodist Church clear. ${ }^{87}$ Even tackling the moral issues the war posed did not strengthen the churches. As Peter Lineham has argued, 'The war heightened the moralism of the churches...Yet the sheer complexity of the moral malaise made it difficult for religious leaders to make specific proposals acceptable to all parties'. ${ }^{88}$ The declining religious observance that occurred during the two world wars was difficult for the churches to curb, and the declining influence of the churches contributed to increasing numbers of people deciding to divorce.

Clearly war, and especially the world wars, affected divorce in numerous ways. There was the direct impact of soldiers serving overseas and the separation which resulted, as well as the trauma endured by some soldiers, although this explanation has often been overstated, particularly in explaining the increase during World War I. Being at war disrupted New Zealand society and resulted in dislocation and permanent change. When the wars finished things did not go back to the way they had been; instead the changes that occurred during the war were to a large extent consolidated, and the divorce rate is one example of this. There was an increasing sense of individuals having the right to act in their own interests, and even if this was not a view shared by all of society, certain individuals were prepared to act on this. As well, throughout this period, there was a growing expectation that marriage should fulfil a greater role in an individual's life, providing companionship, friendship and sexual fulfilment. It is not surprising that this resulted in more people seeking divorce when marriages failed to live up to such high expectations, but at the same time people were willing to try and find this idealised relationship with someone else. Divorce was less visible during the war as society was

\footnotetext{
86 'God and the War'. EP, 10 May 1941.

87 "Methodists' Stand. "It is Right to Fight.", EP, 20 February 1942.

${ }^{88}$ Peter J. Lineham. 'The Religious Face of Patriotism', in Kia Kaha. New Zealand in the Second World War, ed. John Crawford. Auckland: 2000, 213.
} 
preoccupied with more pressing problems, leaving less space in the press for coverage of divorce proceedings. The extent to which the government concerned itself with the marital problems of its citizens, and the coverage given to adultery cases, would suggest that divorces involving the 'betrayal' of a serviceman could still find a space. By framing adultery as 'unpatriotic', the press combined its pre-war exploitation of titillating scandals with its wartime commitments to supporting New Zealand's armed forces.

Men and women experienced war differently and this may have had an isolating effect on their marriages when they were reunited. While war provided some women with new opportunities which sometimes challenged existing feminine norms, as far as men were concerned 'war reinscribed masculinity with the role of defender of women and children', according to Brookes. ${ }^{89}$ Clashes between a seemingly more emancipated femininity and a reinforced 'traditional' masculinity may help explain the increase in divorces. One of the most noticeable trends during the study period is the increase in divorce immediately after both world wars. These changes apparently influenced not only the men who fought, but also civilians from whom the prosperity of war enabled them to secure divorced and perhaps hope that their next relationships would be better than those they had formed before or during the wars.

Finally, during World War II a large number of American soldiers spent time in New Zealand. They were often popular with women, with some New Zealand women marrying them. However, in some circumstances, after marrying New Zealand women, the soldiers were deployed elsewhere in the Pacific and then returned to the United States, abandoning their wife, who never heard from her husband again. The difficulty of obtaining a divorce was such that in 1947 the New Zealand government had to pass special legislation to grant these women divorces. New Zealand soldiers may have returned home to find that their wife was having, or had had an affair with an American. While men's adultery often went unnoticed as it occurred overseas, when women committed adultery, other members of the community often knew, and some felt obliged to inform their absent husbands of their actions. Clearly the wars had a permanent impact on societal values and behaviour. War altered gender relations and ideas about sexuality (particularly women's sexuality) and while some changes were not permanent, the

\footnotetext{
${ }^{89}$ Brookes et al., 2.
} 
consequences of these changes seem to have a longer lasting impact. Although Deborah Montgomerie has argued that World War II did not transform the position of women in New Zealand, clearly permanent changes occurred to gender norms and identities and that these did not revert to what they were prior to either war. ${ }^{90}$ Increases in divorce rates were one indication of these changes and of their effects on both New Zealanders who fought and those who remained in New Zealand during the wars.

${ }^{90}$ Montgomerie. 'Reassessing Rosie', 113. 


\section{Chapter Four}

\section{Class and the Economics of Divorce}

This chapter explores the economics of the divorce process and its consequences. Evidence from the Wellington Divorce Database about occupations, costs awarded in divorce cases and property settlements form the basis for analysis. Using occupation as an indicator of class, this chapter shows that working-class New Zealanders, unlike their counterparts in England and Canada, were more likely to seek divorces than middle and upper class New Zealanders. ${ }^{1}$ It will thus investigate class cultures in New Zealand in regards to marriage and the propensity to seek a divorce while also contrasting these patterns with those in other societies. This examination of marital and divorce-related behaviour will provide insights into an area of class which has yet to attract substantial attention from New Zealand historians.

The cases of Mary Ann C., and Edith and Alexander B. illustrate the issues discussed in this chapter. In December 1894 Edith C. married Alexander B. in Palmerston North. Alexander left Edith in 1903 and began a series of adulterous relationships. In 1912, Edith received specific information about his relationship with a particular woman. She told the court in 1916, when she finally petitioned for divorce, 'I never proceeded against him before because I never had the money to do so'. ${ }^{2}$ From 1908 Edith had been legally entitled to a divorce on the ground of desertion and, then, in 1912, when she heard of her husband's adultery, she could have petitioned for a divorce on that ground. Her financial circumstances meant she had to wait until 1916 to petition for divorce. What is more interesting than the thirteen years Edith waited to divorce her husband, is that she chose to divorce him at all. That same year Mary Ann C. told the court that she had said to her husband, 'If I had the money I would divorce you at once'. ${ }^{3}$ Certainly, many of their counterparts in England did not make the same choice, in part because of the cost, but also because of the long standing practice amongst the lower classes of common law

\footnotetext{
${ }^{1}$ Melanie Nolan has discussed the difficulties of conducting occupational studies in New Zealand, and the importance of the Caversham project, led by Erik Olssen, which explores the social history of southern Dunedin, in providing a model for other New Zealand historians. See Melanie Nolan. 'Constantly on the Move, but Going Nowhere? Work, Community and Social Mobility', in The New Oxford History of New Zealand, ed. Giselle Byrnes. Melbourne: 2009, 362-67.

${ }^{2} B$ v B, AAOM/W3265/D1359/1916/ANZ-W.

${ }^{3} C v C$, AAOM/W3265/D1383/1916/ANZ-W.
} 
marriages, informal divorce and the formation of new 'irregular' unions. ${ }^{4}$ Mary Ann's and Edith's decision to end their marriage legally instead of continuing the British pattern may reflect what John Stenhouse has claimed about working-class New Zealand women. Based upon his study of southern Dunedin, Stenhouse reported many working-class Christian women could be found among "the "puritans", "wowsers", and "moral evangelists", seeking to maintain their reputations for morality and respectability. ${ }^{5}$

Fairburn and Haslett argue that New Zealand's social structure was relatively stable between 1911 and $1951 .{ }^{6}$ Due to the small size of New Zealand's population, there was a large degree of cross-class interaction and the class composition of neighbourhoods varied. ${ }^{7}$ Fairburn argues that this cross-class interaction made 'working-class Tories' of a large number of wage-earners as they were 'heavily exposed' to the views and social pressures of the middle-classes. ${ }^{8}$ Melanie Nolan assigns more agency to the workingclasses, particularly the 'respectable working-classes' and claims 'New Zealand's relatively egalitarian wealth distribution and social safety net is a largely working-class achievement'. ${ }^{9}$ She also emphasises the importance of religion, patriotism, moderate views and the possibility of social mobility for the working classes. The desire of women like Mary Ann C. and Edith B. to have their legal marital status reflect their actual living arrangements suggests that they shared this aspiration to lead a respectable life. Later the development of a state benefit system gave additional reasons for choosing to live in 'regular' unions, but even in the 1910s New Zealand workers revealed a desire for respectability expressed through marriage, and, when the relationship ended, divorce.

Historians have debated the nature of class in New Zealand. Certainly, there were class differences in New Zealand but it was a much more egalitarian society than Britain, from

\footnotetext{
${ }^{4}$ See Ginger S. Frost. Living in Sin. Cohabiting as Husband and Wife in Nineteenth-Century England. Manchester and New York: 2008; Joanne Klein. 'Irregular Marriages: Unorthodox Working-Class Domestic Life in Liverpool, Birmingham, and Manchester, 1900-1939'. JFH 30, no.2 (2005): 210-39.

5 John Stenhouse. 'Church, Occupation and Class in Southern Dunedin, 1890-1940', in Class, Gender and the Vote. Historical Perspectives from New Zealand, eds. Miles Fairburn and Erik Olssen. Otago: $2005,51$.

${ }^{6}$ Miles Fairburn and S.J. Haslett. 'Stability and Egalitarianism: New Zealand, 1911-1951', in Class, Gender and the Vote. Historical Perspectives from New Zealand, eds. Miles Fairburn and Erik Olssen. Otago: 2005, 33.

${ }^{7}$ Miles Fairburn. 'The Farmers Take Over (1912-1930)', in The Oxford Illustrated History of New Zealand, $2^{\text {nd }}$ ed., ed. Keith Sinclair. Auckland: 1996, 203.

${ }^{8}$ Fairburn, 'The Farmers Take Over', 203. See also, Miles Fairburn. 'Why Did the New Zealand Labour Party Fail to Win Office until 1935?’ Political Science 37, no.2 (1985): 116-19.

${ }^{9}$ Melanie Nolan. Kin: A Collective Biography of a New Zealand Working-Class Family. Christchurch: $2005,182$.
} 
where most of the European population had migrated. David Hamer has argued that migrants 'were happy with social hierarchy, as long as it was a dynamic structure with scope for unimpeded ascent by the hard-working and the morally worthy'. ${ }^{10}$ Tom Brooking has discussed the uneven distribution of pre-World War I prosperity saying, 'wage-earners generally fell behind many farmers and self-employed businessmen, and unemployment ran at surprisingly high level'. ${ }^{11}$ During the Depression differences in wealth became starker, with many New Zealanders going without and some rioting, while a much more select group, 'drove to race meetings or exclusive clubs in the latest model cars, and dressed in the height of fashion'. ${ }^{12}$ By the post-World War II period Graeme Dunstall summarises 'most people still retained a general awareness of their position in a broad social layer, although they did not necessarily have a sense of class solidarity...class awareness remained while class consciousness waned'. ${ }^{13}$ Most people had a sense of their class background, but this did not dictate the way in which they lived their lives.

\footnotetext{
${ }^{10}$ David Hamer. 'Centralization and Nationalism (1891-1912)', in The Oxford Illustrated History of New Zealand, $2^{\text {nd }}$ ed., ed. Keith Sinclair. Auckland: 1996, 132.

${ }^{11}$ Tom Brooking. 'Economic Transformation', in The Oxford History of New Zealand, $2^{\text {nd }}$ ed., ed. Geoffrey Rice. Auckland: 1992, 230.

${ }^{12}$ Brooking, 251.

${ }^{13}$ Graeme Dunstall. 'The Social Pattern', in The Oxford History of New Zealand, $2^{\text {nd }}$ ed., ed. Geoffrey Rice. Auckland: 1992, 453.
} 
Table 4.1

Occupations as listed on the Marriage Certificate

\begin{tabular}{|c|c|c|c|c|}
\hline Occupational Categories & $\begin{array}{l}\text { Husbands' } \\
\text { Fathers }\end{array}$ & $\begin{array}{c}\text { Wives' } \\
\text { Fathers }\end{array}$ & Husbands & Wives \\
\hline $\begin{array}{c}\text { Large Employers/ Managers } \\
\text { (01) }\end{array}$ & $\begin{array}{c}16 \\
(0.91)\end{array}$ & $\begin{array}{c}8 \\
(0.46)\end{array}$ & $\begin{array}{c}10 \\
(0.55)\end{array}$ & 0 \\
\hline Professionals (02) & $\begin{array}{c}65 \\
(3.70)\end{array}$ & $\begin{array}{c}51 \\
(2.91)\end{array}$ & $\begin{array}{c}45 \\
(2.46)\end{array}$ & 0 \\
\hline Semi-Professionals (03) & $\begin{array}{c}82 \\
(4.66)\end{array}$ & $\begin{array}{c}73 \\
(4.16)\end{array}$ & $\begin{array}{c}92 \\
(5.04)\end{array}$ & $\begin{array}{c}37 \\
(8.22)\end{array}$ \\
\hline Petty Proprietors (04) & $\begin{array}{c}190 \\
(10.80)\end{array}$ & $\begin{array}{c}164 \\
(9.36)\end{array}$ & $\begin{array}{c}99 \\
(5.42)\end{array}$ & $\begin{array}{c}1 \\
(0.22)\end{array}$ \\
\hline Petty Officials (05) & $\begin{array}{c}95 \\
(5.40)\end{array}$ & $\begin{array}{c}93 \\
(5.31)\end{array}$ & $\begin{array}{c}84 \\
(4.60)\end{array}$ & $\begin{array}{c}1 \\
(0.22)\end{array}$ \\
\hline White-Collars (06) & $\begin{array}{c}124 \\
(7.05)\end{array}$ & $\begin{array}{c}115 \\
(6.56)\end{array}$ & $\begin{array}{c}213 \\
(11.66)\end{array}$ & $\begin{array}{c}49 \\
(10.89) \\
\end{array}$ \\
\hline Skilled (07) & $\begin{array}{c}575 \\
(32.69) \\
\end{array}$ & $\begin{array}{c}554 \\
(31.60)\end{array}$ & $\begin{array}{c}597 \\
(32.68)\end{array}$ & $\begin{array}{c}46 \\
(10.22) \\
\end{array}$ \\
\hline Semi-Skilled (08) & $\begin{array}{c}84 \\
(4.78)\end{array}$ & $\begin{array}{c}99 \\
(5.65)\end{array}$ & $\begin{array}{c}166 \\
(9.09)\end{array}$ & $\begin{array}{c}18 \\
(4.00)\end{array}$ \\
\hline Unskilled (09) & $\begin{array}{c}230 \\
(13.08)\end{array}$ & $\begin{array}{c}290 \\
(16.54)\end{array}$ & $\begin{array}{c}293 \\
(16.04)\end{array}$ & $\begin{array}{c}159 \\
(35.33)\end{array}$ \\
\hline Rural Proprietors (15) & $\begin{array}{c}216 \\
(12.28) \\
\end{array}$ & $\begin{array}{c}208 \\
(11.87) \\
\end{array}$ & $\begin{array}{c}88 \\
(4.82) \\
\end{array}$ & 0 \\
\hline Rural Occupations (16) & $\begin{array}{c}20 \\
(1.14)\end{array}$ & $\begin{array}{c}24 \\
(1.37)\end{array}$ & $\begin{array}{c}31 \\
(1.70)\end{array}$ & 0 \\
\hline Military (officers) (18) & $\begin{array}{c}8 \\
(0.45) \\
\end{array}$ & $\begin{array}{c}6 \\
(0.34) \\
\end{array}$ & $\begin{array}{c}10 \\
(0.55)\end{array}$ & 0 \\
\hline $\begin{array}{c}\text { Military (enlisted and rank } \\
\text { undefined) (19) }\end{array}$ & $\begin{array}{c}7 \\
(0.40) \\
\end{array}$ & $\begin{array}{c}9 \\
(0.51) \\
\end{array}$ & $\begin{array}{c}89 \\
(4.87) \\
\end{array}$ & $\begin{array}{c}3 \\
(0.67) \\
\end{array}$ \\
\hline Undefined (20) & $\begin{array}{c}47 \\
(2.67)\end{array}$ & $\begin{array}{c}59 \\
(3.37)\end{array}$ & $\begin{array}{c}10 \\
(0.55)\end{array}$ & $\begin{array}{c}136 \\
(30.22)\end{array}$ \\
\hline TOTAL & $\begin{array}{c}1759 \\
(100.01)\end{array}$ & $\begin{array}{c}1753 \\
(100.01)\end{array}$ & $\begin{array}{c}1827 \\
(\mathbf{1 0 0 . 0 3})\end{array}$ & $\begin{array}{c}450 \\
(99.99)\end{array}$ \\
\hline
\end{tabular}

Source: Wellington Divorce Database

A disproportionate number of those who legally dissolved their marriages came from the lower occupational ranks of New Zealand's economic order (see Table 4.1). At the same time, as shown in Table 4.2 there was a significant amount of intermarriage between those from different class backgrounds. David Pearson in his study of church marriage registers from Central Wellington between 1881 and 1980 found a significant degree of intermarriage, but also an increasing tendency towards homogamy during the twentieth 
century. ${ }^{14}$ During the twentieth century Pearson notes about two-thirds of grooms married into a family of a similar background to their own. This is not surprising, and Miriam Gilson, like many other sociologists and historians, has argued 'the field of choice [of marriage partner] is often consciously or unconsciously limited to those of like attitudes and interests which result from a common racial, religious or socio-economic background'. ${ }^{15}$ The Wellington Divorce Database shows over half of those grooms, who eventually divorced, had married brides from a different class background, suggesting class exogamy contributed to the incidence of divorce. At the same time, like Pearson's sample, it was more common for professional men to marry a bride from a working-class background than it was for a daughter of a professional to marry a blue-collar worker suggesting that better off parents tended to ensure that their daughters married into the same or higher class, while sons had greater autonomy about their choice of bride. ${ }^{16}$

\footnotetext{
${ }^{14}$ David Pearson. 'Marriage and Mobility in Wellington, 1881-1980'. NZJH 22, no.2 (1988): 150. Erik Olssen has also explored the connection between marriage and class in Southern Dunedin and his findings are similar to those of Pearson, although he suggests a somewhat weaker connection between social class and spousal choice. See Erik Olssen, “For Better, For Worse": Marriage Patterns in Dunedin's Southern Suburbs, 1881-1938', in Class, Gender and the Vote. Historical Perspectives from New Zealand, eds. Miles Fairburn and Erik Olssen. Otago: 2005, 87-95. Of the 2,195 divorce files consulted, in 1,114 cases the marriage occurred in the Greater Wellington area, in another 811 cases it occurred elsewhere in New Zealand, in 266 cases it occurred overseas, and in 14 cases no place of marriage was identified. Pearson's study, like this one, used grooms' occupations as listed on the marriage certificate and brides' fathers' occupations to measure the degree of cross-class marriage. It was not until the 1950s that most women recorded their paid occupation on the marriage certificate, hence the need to use their fathers' occupations. Pearson does point out that comparing the bride's father's occupation and the groom's occupation is problematic as it 'refers to different points in their career structure'. Pearson, 138. Miles Fairburn and S.J. Haslett encountered the same problem in their study and concluded that the 'high proportion [of women who] were not given an occupational designation' is 'a reflection of the gendered nature of social labelling in the period and partly as a consequence of the exceptionally low participation rate of women in the paid workforce', Fairburn and Haslett, 18. See also, Nolan, 'Constantly on the Move', 361.

${ }^{15}$ Miriam Gilson. 'The Changing New Zealand Family: A Demographic Analysis', in Marriage and the Family in New Zealand. ed. Stewart Houston. Wellington: 1970, 43. Using occupation as an indicator of class is not without its problems, but as it is the only evidence available from the majority of divorce files it is the best available option. Moreover, Olssen and Hickey have argued that by the nineteenth century, 'men came to be characterised more by their occupations than by kinship or any other criterion'. See Erik Olssen and Maureen Hickey. Class and Occupation. The New Zealand Reality. Dunedin: 2005, 9.

${ }^{16}$ Pearson, 140.
} 
Table 4.2

Distribution in Occupational Categories of Grooms and Brides' Fathers, 1898-1947 (percentages)

\begin{tabular}{|c|c|c|c|c|c|}
\hline \multirow[t]{2}{*}{ Groom's Occupational Category } & \multicolumn{5}{|c|}{$\begin{array}{c}\text { Bride's Father's Occupational } \\
\text { Category }\end{array}$} \\
\hline & 1 & 2 & 3 & 4 & $N$ \\
\hline $\begin{array}{l}\text { 1.Larger Employers/Managers, Professionals, } \\
\text { Semi-Professionals and Military Officers }\end{array}$ & 20.98 & 30.77 & 37.06 & 11.19 & 143 \\
\hline $\begin{array}{l}\text { 2. Petty Proprietors, Petty Officials and } \\
\text { White-Collar Workers }\end{array}$ & 10.34 & 27.93 & 50 & 11.73 & 358 \\
\hline $\begin{array}{l}\text { 3. Skilled, Semi-Skilled, Unskilled and } \\
\text { Military (enlisted and rank undefined) }\end{array}$ & 5.59 & 19.27 & 62.29 & 12.85 & 1074 \\
\hline 4. Rural Occupations & 6.48 & 16.67 & 45.37 & 31.48 & 108 \\
\hline
\end{tabular}

Source: Wellington Divorce Database

As the Wellington Divorce Database demonstrates, working class New Zealanders were more likely to divorce than middle or upper class New Zealanders. This is in contrast to the situation in Canada and England where wealthier people were more likely to divorce suggesting that divorce was more affordable in New Zealand. ${ }^{17}$ The costs of divorce varied little across the study period, suggesting divorce became cheaper in real terms. Table 4.3 compares the occupations of husbands at the time of divorce with the nonMaori urban population as a whole, using the classification system developed by Olssen and Hickey. ${ }^{18}$ While Snell has used a different classification system, his figures can still be used to make some general comparisons. For Canada, he found the bourgeoisie, the petite bourgeoisie, management and white-collar workers sought divorce at a rate roughly double their numbers in the general population and professionals and semi-professionals were three times more likely to petition for divorce as their presence in the general population would suggest. The number of foremen and blue-collar workers who divorced was similar to their proportion in the population as a whole. Unskilled workers were severely underrepresented making up only about 10 per cent of those divorcing despite being about 30 per cent of the population. Snell attributes the underrepresentation of workers to the cost of divorce. ${ }^{19}$

\footnotetext{
${ }^{17}$ Lawrence Stone notes that when the British Labour Government made legal aid more widely available for divorce proceedings in 1948, the proportion of petitions supported by legal aid increased from a fifth to over a half, suggesting that more people on lower incomes were divorcing. See, Road to Divorce: England 1530-1987. Oxford: 1990, 402.

${ }^{18}$ For a full breakdown of occupations see the Appendix, 235.

${ }^{19}$ James G. Snell. In the Shadow of the Law. Divorce in Canada 1900-1939. Toronto: 1991, 221-22.
} 
Table 4.3

New Zealand's non-Maori Male urban occupational structure 1901, 1926 and 1936 Compared with the Breakdown of Husbands' Occupations at the time of Divorce (excluding rural, students, military and undefined occupations)

\begin{tabular}{|c|c|c|c|c|c|c|c|c|c|}
\hline $\begin{array}{c}\text { Occupational } \\
\text { Categories }\end{array}$ & $\begin{array}{c}1901 \\
\text { Census } \\
\end{array}$ & & $\begin{array}{l}\text { 1898-1907 } \\
\text { Divorcees }\end{array}$ & $\begin{array}{c}1926 \\
\text { Census } \\
\end{array}$ & & $\begin{array}{l}\text { 1923-1932 } \\
\text { Divorcees }\end{array}$ & $\begin{array}{c}1936 \\
\text { Census } \\
\end{array}$ & & $\begin{array}{l}1933-1942 \\
\text { Divorcees } \\
\end{array}$ \\
\hline $\begin{array}{c}\text { Large } \\
\text { Employers/ } \\
\text { Managers (01) }\end{array}$ & 2.02 & $\downarrow$ & 0 & 4.96 & $\downarrow$ & 1.79 & 3.82 & $\downarrow$ & 1.53 \\
\hline $\begin{array}{c}\text { Professionals } \\
\text { (02) }\end{array}$ & 2.43 & $\downarrow$ & 1.09 & 3.94 & $\downarrow$ & 3.21 & 3.61 & - & 3.56 \\
\hline $\begin{array}{c}\text { Semi- } \\
\text { Professionals } \\
(03)\end{array}$ & 3.50 & $\uparrow$ & 4.35 & 3.19 & $\downarrow$ & 2.50 & 3.21 & $\uparrow$ & 6.11 \\
\hline $\begin{array}{c}\text { Petty } \\
\text { Proprietors (04) }\end{array}$ & 17.06 & $\downarrow$ & 15.22 & 9.90 & $\downarrow$ & 7.50 & 9.21 & $\downarrow$ & 3.05 \\
\hline $\begin{array}{l}\text { Petty Officials } \\
(05)\end{array}$ & 5.25 & $\downarrow$ & 4.35 & 5.78 & - & 5.71 & 6.56 & 个 & 8.65 \\
\hline $\begin{array}{c}\text { White-Collars } \\
\text { (06) }\end{array}$ & 12.61 & $\downarrow$ & 9.78 & 17.79 & $\downarrow$ & 15.00 & 20.53 & $\downarrow$ & 13.49 \\
\hline Skilled (07) & 21.39 & $\uparrow$ & 25.00 & 27.59 & $\uparrow$ & 31.07 & 25.18 & $\uparrow$ & 34.10 \\
\hline Semi-Skilled (08) & 8.47 & $\uparrow$ & 10.87 & 5.96 & $\uparrow$ & 11.79 & 7.42 & $\uparrow$ & 12.47 \\
\hline Unskilled (09) & 27.28 & $\uparrow$ & 29.35 & 20.89 & $\uparrow$ & 21.43 & 20.77 & $\downarrow$ & 17.05 \\
\hline TOTAL & 100 & & $\begin{array}{l}100.01 \\
N=92\end{array}$ & 100 & & $\begin{array}{c}100 \\
\mathrm{~N}=280\end{array}$ & 100 & & $\begin{array}{l}100.01 \\
N=393\end{array}$ \\
\hline
\end{tabular}

Source: Erik Olssen and Maureen Hickey. Class and Occupation. The New Zealand Reality. Dunedin: 2005, 101 and Wellington Divorce Database. $\uparrow / \downarrow$ indicating above/below general trend.

In general, men who divorced in New Zealand came from skilled, semi-skilled and unskilled occupations rather than from the ranks of large employers/managers, professional and petty proprietor categories. This New Zealand pattern is in direct contrast to what James Snell has found in Canada. The only similarity with New Zealand is that Canadian farmers, like their New Zealand counterparts, were very unlikely to divorce. ${ }^{20}$ Snell explains the middle class used divorce to protect property rights and that workers sought divorces so they could form new marriages which 'would ensure their physical and economic survival'. ${ }^{21}$ The New Zealand evidence suggests this need for

\footnotetext{
${ }^{20}$ Snell, 220. While farmers have not been included in Table 4.3, as it is limited to urban occupations, Table 4.1 shows the marked difference between the proportion of husbands' and wives' fathers who were farmers and grooms who were farmers, although this data has been collected from cases heard in the Wellington Supreme Court. Had other Supreme Courts, such as Masterton, been included in the sample, the results may have been different.

${ }^{21}$ Snell, 223. There is little data on the occupational background of English divorcees, although it is generally claimed that divorce was too expensive and inaccessible for the majority of English people with the introduction of judicial divorce in 1857 reducing the cost of divorce from $£ 2,000$ to $£ 300$. Gail Savage has analysed a sample of divorce files from 1858-1867 which show more working-class couples than expected, but certainly they are underrepresented compared with the population as a whole. See Gail
} 
physical and economic survival may have been a particularly strong motivation for the occupational groups more likely to divorce.

The fragility of marriage among the skilled, semi-skilled, and unskilled may, in part, stem from the mobility that reflected their economic vulnerability to unemployment, low wages, and the effects of illness. ${ }^{22}$ New Zealanders tended to be more mobile than the British or even Americans. In 1890, just prior to the beginning of the period under study, there was a 60 per cent chance a household would move from a locality within a ten-year period. ${ }^{23}$ Some jobs required husbands to be away from home and others required a great deal of mobility or allowed for mobility. Mobility in and of itself may have made marriages more vulnerable as the couple were not so closely linked to a community, and the potential for mobility may have made people more likely to consider divorce as it would be possible to move to another town and escape the disapproval of the community. A number of cases heard in the New Zealand courts involved one spouse, normally the husband, who had migrated to New Zealand from Britain with the understanding that his wife would follow once he was established. ${ }^{24}$ But when wives did not follow their husbands petitioned for divorce. Ralph C., for example, petitioned for divorce in 1927 from his wife Phillis, who remained in England with their two children, after a separation of six years. ${ }^{25}$

Savage. "'Intended Only for the Husband": Gender, Class, and the Provision for Divorce in England, 18581868', in Victorian Scandals. Representations of Gender and Class, ed. Kristine Ottesen Garrigan. Athens: 1992, 11-42. The only figures I have located a for England for the first half of the twentieth century are from 1907 when 28.87 per cent of divorce petitions involved working-class couples and in 1908 when there figure was 26.33 per cent. See Appendices to the Minutes of Evidence and Report of the Royal Commission on Divorce and Matrimonial Causes. London: 1912, appendix III, table XVa, 35.

${ }^{22}$ Olssen has found that those in occupational categories 1-3 married later than those in categories 4-9. This may have also contributed to the greater stability of middle and upper-middle class marriages as those who married young were more likely to divorce than those who delayed marriage (see Chapter Two). Olssen, 'For Better, For Worse', 81-82.

${ }^{23}$ Nolan. 'Constantly on the Move, But Going Nowhere?', 369. Beverly Schwartzberg has also noted, with reference to post-Civil War America that geographical mobility made taking on a new identity and committing desertion or bigamy much easier. See "'Lots of Them Did That": Desertion, Bigamy, and Marital Fluidity in Late-Nineteenth-Century America'. JSH 37, no.3 (2004): 582. A person's mobility also affected whom they would marry in the first place. Peter Perry found in his study of Oamaru between 1875 and 1914 that most people married someone who lived no more than a day's horse ride away. See 'Marriage-Distance Relationship in North Otago 1875-1914'. New Zealand Geographer 25, no.1 (1969): $36-43$.

${ }^{24}$ For a brief study of such cases from the English perspective see, Olive Anderson. 'Emigration and Marriage Break-Up in Mid-Victorian England'. The Economic History Review 50, no.1 (1997): 104-9.

${ }^{25} C \vee C$, AAOM/W3265/D3035/1927/ANZ-W. For other similar cases see, $G v G$, AAOM/W3265/D4036/ 1932/ANZ-W; $D v D$, AAOM/W3265/D3427/1938/ANZ-W. 
What follows is only a selection of examples showing the multiple moves by couples who ended up in the divorce court in Wellington. In a 1908 case where the couple had been married for 25 years, the husband's employment as a basket maker made for a very mobile existence. They lived in Christchurch for nine years (where they married), Melbourne for five years, then Wellington, Auckland, Dunedin, Oamaru and then again in Wellington. ${ }^{26}$ In 1906, the Evening Post reported on the Olsen divorce case that, 'They lived in humble circumstances and the respondent drifted about from Wellington to Palmerston and Feilding and back again, leaving his wife struggling for an existence. She had maintained herself and her daughter by cleaning the Customs' offices, for which she obtained 25s per week'. ${ }^{27}$ Sydney, a carpenter, and Rebecca H. married in Plymouth, England in 1919 and separated in September 1934. During their marriage they lived at Plymouth then Wellington, Paekakariki, Melbourne, Fremantle, Northcliffe, Pemberton in Western Australia, again at Fremantle and Melbourne, then again at Wellington and finally at Petone. ${ }^{28}$ Wilfred G. and Hilda T. married in Staffordshire, England in 1917. Wilfred claimed that he left England in 1926 with his wife's consent and went to Australia. In 1928 he wrote to his wife asking her to join him in Australia but she refused. When he moved to New Zealand he asked her to join him. She advised him to get a divorce because she would not join him. ${ }^{29}$ Separation and mobility that may have been driven by economic goals resulted in ending marriages between some couples.

Mobility and separation could also erode the bonds of marriage among the more economically prosperous. In a 1912 case where the couple had married in Essex in 1897, the husband's occupation as a clerk had taken them to Kent, Leicester, Hereford, Leamington, Crowborough, Feltham and Oakhanger, Durban in Natal, Alton in Hampshire, England, and Wellington. ${ }^{30}$ In her petition in 1917, Irene Y. explained she had lived with her husband in Dunedin, 'throughout the North and South Islands of New Zealand in her husband's theatrical company, then lived with her husband at Melbourne in the State of Victoria, and afterwards at Wellington and in Invercargill' ${ }^{31}$ In 1945 Margaret W. told the court, 'We continued living in New Plymouth and my husband has been out of that town on essential employment for some years. For the last 12 months or

\footnotetext{
${ }^{26} A v A \& R$, AAOM/W3265/D942/1909/ANZ-W.

27 'Divorce Court'. EP, 12 February 1906.

${ }^{28} H v H$, AAOM/W3265/D5069/1937/ANZ-W.

${ }^{29} G v G$, AAOM/W3265/D5453/1939/ANZ-W.

${ }^{30} C v C \& R$, AAOM/W3265/D1122/1912/ANZ-W.

${ }^{31} Y \vee Y$, AAOM/W3265/D1555/1917/ANZ-W.
} 
more he has been out here in Wellington. He had associations with a lady named Ruth and I have received a letter from him. As a result of those communications I interviewed my husband. I taxed him with committing adultery with this woman and he admitted he had'. ${ }^{32}$ Occasionally the same patterns occurred when it was the wife who travelled. In his 1942 petition, Henry I. explained how he helped his wife in her display model business which required her to visit central Sydney to make repairs to the models while Henry remained at home in suburban Sydney making models. Through her work she became involved with another man and later decided to end her marriage through divorce. ${ }^{33}$

Occupations such as the arts, journalism and politics also appear to display factors which made divorce more probable, which may also reflect factors such as mobility and separation in the case of politicians and rejection of the codes of respectability in the case of artists. When considering divorced New Zealanders listed in the Dictionary of New Zealand Biography, several patterns emerge. ${ }^{34}$ Ninety-seven individuals are recorded as having divorced at least once before 1960, although not all these divorces occurred in New Zealand. Forty-one of these people were involved in the arts, journalism or broadcasting and include New Zealand Listener editors Oliver Duff and Monte Holcroft (who divorced twice), Katherine Mansfield, Rita Angus, Nola Luxford (who also divorced twice), Len Lye and Eric Ramsden. There were ten political activists or unionists including Margaret Hawthorne and Miriam Soljak, and eleven politicians or other prominent public figures including Arthur Porritt who was later made GovernorGeneral of New Zealand, Dove-Myer Robinson (divorced three times) who was later mayor of Auckland for 18 years, the Ngai Tahu politicians and brothers Henare and Hopere Uru, and Janet Fraser, the community leader and wife of Prime Minister Peter Fraser. ${ }^{35}$ The concentration of these two areas of interest amongst prominent divorcees in

\footnotetext{
${ }^{32} W v W$, AAOM/W3265/D2141/1945/ANZ-W.

${ }^{33}$ I $v$ I, AAOM/W3265/D645/1942/ANZ-W.

${ }^{34}$ This group of New Zealanders are clearly not representative of the population as a whole. There is a strong weighting towards those who were prominent or had a position in some sphere of public life.

${ }^{35}$ Janet Fraser had divorced he first husband, George Kemp on the ground of his adultery in 1919. The decree absolute was issued on 4 October, and she married Peter Fraser on 1 November, the same year. According to Peter Fraser's biographers, Peter and Janet 'shared a strong sense of propriety, and almost certainly there was nothing sexual about their relationship during these years [1913-1919]; in the puritanical environment of the time they maintained separate establishments until they married in the Wellington registrar's office...It would have taken considerable gall on Janet's part to have divorced Kemp on the grounds of adultery if she had been engaged in the same thing herself'. See, Michael Bassett with Michael King. Tomorrow Comes the Song. A Life of Peter Fraser. Auckland: 2000, 46. Bassett and King fail to consider that people did not always use the courts to 'punish' 'immoral' behaviour, and that the Kemps may have agreed to end their marriage and in 1919 the quickest and easiest way to do this was a non-defended
} 
New Zealand suggests that those who divorced belonged to bohemian arts and literati groups, or had leftist political inclinations placing them outside conventional society. The ability to become prominent and even become important political leaders also suggests that divorce did not preclude success in some very public fields. ${ }^{36}$

Economic conflicts may have brought a couple into the divorce court. The pregnancy that was the catalyst for a cross-class marriage in 1912 may have also caused its dissolution. Thomas L., an accountant and the son of a gentleman, married Elizabeth C., a miner's daughter at the Wellington Registry Office. In her petition for divorce on the ground of desertion five years later, Elizabeth claimed the couple had only cohabited for five days after their wedding. Two months later, she gave birth to their daughter, but her husband had departed for the United States leaving behind a legitimate child but a deserted spouse. ${ }^{37}$ Sometimes the wife's family had greater wealth. In July 1946, Maurice O. petitioned for a restitution of conjugal rights. The couple married in April 1946 and lived in a house owned by the bride's father. Dorothy returned to her parental home and her parents informed her husband the marriage had ended and he could not remain in their house. Maurice particularly noted the hostile 'attitude of [Dorothy's] mother' which he believed 'made it extremely likely that a breach of peace would occur' if he did not comply with her demands. The aggrieved husband believed her parents' 'interference' had brought the marriage to the divorce court. ${ }^{38}$ Here the wife's economic advantage reversed the typical situation leading to tensions between the couple and in-law difficulties stemming from assumptions about the husband's role as provider.

Her greater resources may explain both the marriage and also the divorce of Maata Mahupuku. Married in Greytown in 1914 to Thomas Asher, Mahupuku was a landowner. ${ }^{39}$ Money created conflict in the Asher household with Maata having to pay

divorce on the ground of adultery. Men accused of adultery were not stigmatised in the same way that women were, which would have been one of the reasons for Janet to petition for the divorce. That is not to say that Peter and Janet did commit adultery, only that Bassett and King have written off the possibility too easily.

${ }^{36}$ See relevant entries in the DNZB available at: www.dnzb.govt.nz.

${ }^{37} L v L$, AAOM/W3265/D1495/1917/ANZ-W.

${ }^{38} O$ v $O$, AAOM/W3265/D2673/1946/ANZ-W.

${ }^{39}$ Mahupuku had not lost her money or land during her divorce from her first husband (which was on the ground of her adultery with Asher) as it was held in trust for her. While Maori women's interest in tribal lands were protected, once this land had passed through the Native Land Court and ownership had been individualised, it was only protected by the Married Women's Property Act 1884, in the same way that European women's property was protected. See Bettina Bradbury. 'From Civil Death to Separate Property. 
Tom's debts for him on many occasions. In 1924 Maata asked the Magistrates' Court to issue a Separation Order on the grounds of Tom's failure to maintain her and their two children and his persistent cruelty towards her and their children. Letters in the divorce file from 1930 show Tom complaining about Maata sending bailiffs to his home on a number of occasions. In December 1924 Tom and Maata reunited. She paid his debts of over £300. In March 1930, however, Tom 'stole from [Maata] an open cheque for $£ 25$ for rent...cashed it and went to the Wellington Races'. Maata presented herself to the court as a victim of Tom despite being far wealthier than he was, and seeing her money as precisely that, her money, and not his. Embedded in the legislation covering matrimonial dissolution was the presumption that husbands had access and control of money and wives did not. This meant that when husbands petitioned for divorce they had to provide security for their wives' legal costs, which is what Tom had to do, despite it being very clear that he had almost no money and Maata had a substantial amount of money. ${ }^{40}$ Her wealth may have brought them together but financial disputes ultimately contributed to the couple divorcing.

Conflicts over money were another form of economic pressure which brought some couples into the divorce court, explaining at least part of the reason for higher proportions of divorce among the less well off. Usually the problem stemmed from husbands' failing to provide adequately for the family, which was considered to be their primary role within marriage. In their failure as breadwinners they gave their wives fewer reasons to stay in the marriage. This was the case for Alice and Henry W. She claimed that her husband had left her in Gisborne in July 1908 to find work in Dannevirke. After waiting three months and receiving no money Alice went to Dannevirke. She stated in an affidavit,

He made all kinds of excuses to me and offered me no money, telling me I had better obtain a situation and work for twelve months, and I obtained a situation, came to him again after a further period of four months and when there was still no improvement, he having no home to offer me. He stated that he had no money himself and that he was in debt. He asked me if I had any money. I said "Yes, I have a little" and I gave him $£ 10 .{ }^{41}$

In 1916 she commenced proceedings in the Magistrates' Court under the Destitute Persons Act 1910 for maintenance and separation. Her husband claimed, however, he had

Changes in the Legal Rights of Married Women in Nineteenth-Century New Zealand'. NZJH, 29, no.1 (1995): 44-45.

${ }^{40}$ Asher $v$ Asher \& Elliott, AAOM/W3265/D3820/1931/ANZ-W.

${ }^{41} W v W$, AAOM/W3265/D1451/1916/ANZ-W. 
been living with, and supporting, another woman and needed to maintain 'our three infant children aged, 13, 10 and 7 years respectively' in $1925 .{ }^{42}$ Alice did not follow her petition through to court and the case was abandoned. A similar situation occurred in the case of Elizabeth M., whose husband went to Hamilton in 1938 leaving her without 'any money' and forcing her to take up employment as a maid at the North Egmont Hostel. ${ }^{43} \mathrm{~A}$ separation, which may have become the cause of a divorce when the wife recognised she could support herself, may explain the divorce of Alexander J. and Ima R. In December 1939, Alexander petitioned for divorce on the ground of failure to comply with a restitution of conjugal rights. He told the court they had lived at Lyall Bay after their wedding, but that as his wife was 'in business' in Wellington, she stayed in town during the week. However, in November he claimed his wife decided to live in town with her parents all the time. ${ }^{44}$ Economic tensions suggested money was often at the crux of the decision to divorce.

Once a case was heard in court, and either the judge or jury decided there were grounds for a divorce, a decree nisi was issued. Three months later either spouse could request that a decree absolute be issued, and then the marriage was fully dissolved. At the same time as the issuing of the decree nisi requests for costs and damages were considered. Any wife who petitioned for divorce, regardless of the ground, could request her husband pay the costs. Husbands who petitioned for divorce on the ground of adultery, and named a co-respondent, could request the co-respondent pay the costs. In the first instance, however, the husband would have to cover his wife's costs if she chose to defend the petition, but he could later be reimbursed by the co-respondent, assuming that adultery was proved. In 473 cases a specific order for costs was made, while in a further 352 cases costs were awarded, but an exact amount was not specified. For the entire period the mean costs awarded was $£ 25 / 18 / 11$ and the median was $£ 22 / 6 / 6$. The smallest amount awarded was $£ 1 / 10 /-$ in 1920 and the largest amount was $£ 267 / 1 / 11$ in 1944 . Awards for costs were generally made in cases where the wife was the petitioner and the husband was ordered to pay costs, or adultery cases where the husband was the petitioner and the corespondent was ordered to pay costs. There was little change across the period in the amounts being awarded, which suggests the award for costs was covering a smaller and

\footnotetext{
${ }^{42} W v W$, AAOM/W3265/D1451/1916/ANZ-W.

${ }^{43} M v M$, AAOM/W3265/D5493/1939/ANZ-W.

${ }^{44} J v J$, AAOM/W3265/D5505/1939/ANZ-W.
} 
smaller percentage of the total cost of the divorce during the first half of the twentieth century, or that divorce was becoming more affordable in real terms.

Table 4.4

Awards for Costs Made in Divorce Cases, Wellington Supreme Court, 1898-1947

\begin{tabular}{c|ccccc}
\hline & $\mathbf{1 8 9 8 - 1 9 0 7}$ & $\mathbf{1 9 0 8 - 1 9 1 7}$ & $\mathbf{1 9 1 8}-\mathbf{1 9 2 7}$ & $\mathbf{1 9 2 8}-\mathbf{1 9 3 7}$ & $\mathbf{1 9 3 8}-\mathbf{1 9 4 7}$ \\
\hline Mean & $£ 25 / 14 / 3$ & $£ 25 / 4 / 10$ & $£ 26 / 8 / 7$ & $£ 25 / 11 / 5$ & $£ 26 / 5 / 1$ \\
Minimum & $£ 3 / 9 /-$ & $£ 15 /-/-$ & $£ 1 / 10 /-$ & $£ 2 / 2 / 0$ & $£ 3 / 8 /-$ \\
Maximum & $£ 83 /-/-$ & $£ 98 / 17 /-$ & $£ 94 / 18 /-$ & $£ 150 / 1 / 3$ & $£ 267 / 1 / 11$ \\
$\mathbf{N}$ & 41 & 42 & 121 & 132 & 133 \\
\hline
\end{tabular}

Source: Wellington Divorce Database

Table 4.4 shows the awards for costs made in divorce cases heard by the Wellington Supreme Court between 1898 and 1947 where an exact award for costs was made. To contextualise these figures, the average male annual income in 1927 was $£ 226 / 12 / 8$, in 1937 it was $£ 238 / 2 / 4$, and in 1947 it was $£ 350 / 2 / 8$. ${ }^{45}$ Noticeably there is little significant change in the mean amount of costs awarded across the fifty year period. This, combined with the fact that where the exact amount was unspecified, costs were awarded almost always on the lower scale, suggests that while respondents and co-respondents were expected to cover the costs of the divorce proceedings they were not expected to pay excessive costs in the vast majority of cases. In the small number of cases where the amounts awarded were high, this was because the case was contested and involved a large number of witnesses, some of whom had to travel a considerable distance to give evidence in court, and these costs had to be covered by the litigants.

As well as being able to request the co-respondent pay costs, husbands who petitioned for divorce on the ground of adultery could request the courts award damages. This was essentially a hangover from the criminal conversation suits that were possible in England prior to 1857. The New Zealand divorce laws, like the 1857 English law, abolished the action for criminal conversation, but it survived in the form of damages that could be requested by husbands. ${ }^{46}$ This remained part of New Zealand law until 1975 . Wives could not seek damages from the woman with whom their husband had committed adultery.

\footnotetext{
${ }^{45}$ Report on Prices, Wages, and Labour Statistics of the Dominion of New Zealand 1947. Wellington, 1948: viii.

${ }^{46}$ Keith Thomas. 'The Double Standard'. Journal of the History of Ideas 20, no.2 (1959): 212. See also, Ursula Vogel. 'Whose Property? The Double Standard of Adultery in Nineteenth-Century Law', in Regulating Womanhood. Historical Essays on Marriage, Motherhood and Sexuality, ed. Carol Smart. London: 1992, 147-65.
} 
While this was certainly a continuation of the double standard, after the grounds for divorce were equalised in 1898 , in practice it was not very significant. From a total of 391 adultery cases where the husband was the petitioner, in only 39 cases did the husband request that the co-respondent be ordered to pay damages (see Table 4.5). In only 14 cases were damages eventually awarded, and in half of these cases the damages awarded were less than the amount requested.

Table 4.5

Damages Requested and Awarded by Decade

\begin{tabular}{c|ccc}
\hline & $\begin{array}{c}\text { Number of Cases in } \\
\text { Number of Adultery } \\
\text { Cases in which the } \\
\text { husband was the } \\
\text { petitioner }\end{array}$ & $\begin{array}{c}\text { which Damages were } \\
\text { Requested } \\
\text { and as a percentage of } \\
\text { adultery cases where } \\
\text { the husband was the } \\
\text { petitioner }\end{array}$ & $\begin{array}{c}\text { Number of Cases in } \\
\text { which Damages were } \\
\text { Awarded and as a } \\
\text { percentage of cases } \\
\text { where damages were } \\
\text { requested }\end{array}$ \\
\hline $\mathbf{1 8 9 8}-\mathbf{1 9 0 7}$ & 40 & $4(10 \%)$ & $1(25 \%)$ \\
$\mathbf{1 9 0 8}-\mathbf{1 9 1 7}$ & 55 & $0(0 \%)$ & 0 \\
$\mathbf{1 9 1 8}-\mathbf{1 9 2 7}$ & 73 & $11(15.07 \%)$ & $4(36.36 \%)$ \\
$\mathbf{1 9 2 8}-\mathbf{1 9 3 7}$ & 69 & $13(18.84 \%)$ & $4(30.77 \%)$ \\
$\mathbf{1 9 3 8}-\mathbf{1 9 4 7}$ & 154 & $11(7.14 \%)$ & $5(45.45 \%)$ \\
\hline TOTAL & $\mathbf{3 9 1}$ & $\mathbf{3 9}(\mathbf{9 . 9 7 \%})$ & $\mathbf{1 4}(\mathbf{3 5 . 9 0 \%})$ \\
\hline $\mathbf{S 0}$ & & &
\end{tabular}

Source: Wellington Divorce Database

There are a number of reasons why few petitioners requested the co-respondent pay damages. Firstly, all cases involving damages had to be heard before a judge and jury, rather than a judge alone. This increased the cost of the case, which the petitioner had to pay for initially, and also increased the exposure involved. Secondly, there was little point in having the court award damages the co-respondent could not pay. Table 4.6 shows, however, in the few cases where damages were awarded, the amounts were substantial, although usually less than what the petitioners had asked for. Based upon the occupations of those involved in divorce it is clear that most litigants had little money to pay damages. At the same time, an analysis of the occupations of those co-respondents ordered to pay damages shows it was those at the lower end of the income scale who were most likely to be made to pay damages. Likewise, when the petitioner's occupation is considered, it was mostly men at the lower end of the pay scale who requested damages. The sample is relatively small, and so it is difficult to generalise too greatly, but the other noticeable trends were petitioners in rural occupations were over-represented in those husbands requesting damages, and co-respondents in rural occupations were mostly likely to be 
required to pay damages, perhaps reflecting the important economic role rural wives played. Brooking has pointed out that in 1926 the Census showed 60 per cent of New Zealand farmers hired no labour, relying 'entirely on their own labour and that of their families and neighbours', again highlighting the importance of the family as an economic unit in rural communities. ${ }^{47}$

Table 4.6

Damages Requested and Awarded in Adultery Cases, 1898 - 1947

\begin{tabular}{c|cc}
\hline & Damages Requested & Damages Awarded \\
\hline Median & $£ 500$ & $£ 437 / 10 /-$ \\
Minimum & $£ 100$ & $£ 50$ \\
Maximum & $£ 2500$ & $£ 1500$ \\
N & 39 & 14 \\
\hline
\end{tabular}

Source: Wellington Divorce Database

Another possible reason for only a small number of requests for damages is that litigants arranged their own payments informally. For example, Frank L. was named as the corespondent in Hector O'.s divorce petition in January 1920. In his answer he denied committing adultery with Hector's wife Mary Ann, but stated,

if it is proved he committed adultery as alleged in paragraph 3 and 4 of the said petition and that the Petitioner has suffered damage in consequence thereof then he says the Petitioner on or about the $15^{\text {th }}$ day of February 1920 agreed with co-respondent to accept the sum of $£ 250$ in settlement of such damages and the Petitioner received from the co-respondent the sum of $£ 25$ and a promissory notes for $£ 225$ due $15^{\text {th }}$ day of February $1921 .^{48}$

Rather than leaving the decision up to the jury, who not only decided if damages should be awarded, but also the amount of the damages, litigants came to their own agreements which were less public and could also take into account chattels, the custody of children and the re-marriage of the wife. In most cases, these arrangements never appear in the divorce file so it is impossible to know how common such agreements were.

Despite divorce being much more affordable in New Zealand than in Canada or England, there were some people for whom it was still too expensive. A few of these, such as Florence G. in 1941, applied to sue for divorce in forma pauperis. In her affidavit she stated, 'That after payments of my just debts I am not worth more than the sum of $£ 50$

\footnotetext{
${ }^{47}$ Brooking, 233; Claire Toynbee. Her Work and His. Family, Kin and Community in New Zealand 19001930. Wellington: 1995, 47-61.

${ }^{48} O \vee O \& L$, AAOM/W3265/D1863/1920/ANZ-W.
} 
save and except my wearing apparel....That I am employed on light duties for three days in the week and earn $£ 1$ per week from this employment. I also receive $£ 1$ social security... That in my present circumstances I have no prospect of saving sufficient funds to satisfy the usual costs of the divorce suit'. ${ }^{49}$ To qualify to sue in forma pauperis was difficult as the criteria were very strict and of the 2,195 files consulted, in only 24 did the petitioner apply to sue for divorce in forma pauperis. In 19 of these cases, the petitioner was successful in this application. Nevertheless, it still offered a route to legal marital dissolution which even the most desperately poor New Zealanders could pursue.

Since most couples who divorced were working class, the divorce files do not include substantial evidence regarding property distribution after divorce as few couples had much to divide. Those that did suggest women, especially those with children, were allocated a share of the property even though it may not have been held in their name. ${ }^{50}$ The Married Women's Property Act 1884 provided limited protection to wives as it only covered property they had brought to the marriage or had acquired after marriage and retained as separate property. As Jenkins explains, 'an overwhelming majority of wives who did not have separate property, continued to experience financial insecurity'. ${ }^{51}$ Property settlements thus applied to the tiny minority who came from higher occupational positions such as Sarah and John S., who married in 1900 in Waimate. After the granting of the decree absolute in 1924 there was much litigation over the issue of permanent maintenance. Sarah claimed her husband earned more than $£ 1,000$ a year as a dentist and owned property in the Hawkes Bay and in Wellington with a combined value of $£ 5,250$. In reply, John stated his income from his dentistry practice did not exceed $£ 750$ per year and his 'said practice has suffered owing to the publicity of these proceedings and [his] income from the said practice has diminished and is diminishing'. He admitted owning property in the Hawkes Bay and Wellington but challenged the value claimed by his wife, and said that some of the properties were mortgaged. He also claimed his wife owned property in Hastings. Their disagreements continued with Sarah asking for $£ 8 / 10 /-$ per week ( $£ 442$ per year) for her and her two children. ${ }^{52}$ The prosperous, especially, could not

\footnotetext{
${ }^{49} G v G$, AAOM/W3265/D393/1941/ANZ-W.

${ }^{50}$ Justine Jenkins considers a number of court decisions regarding property and maintenance in separation and divorce cases. See 'Mine, Yours, Ours. An Economic Analysis of the Development of Matrimonial Property and Divorce Law in New Zealand 1880-1980'. MA thesis, University of Auckland, 2001, 58-94.

${ }^{51}$ Jenkins, 42.

${ }^{52} S v S$, AAOM/W3265/D2427/1923/ANZ-W.
} 
always end their marriages with mutual satisfaction, while wives tried to avoid the loss of status and income that was likely for women during divorce proceedings.

Children posed another issue for divorcing couples which led to disputes about maintenance. Mary P., 27 years, petitioned for divorce on the ground of three years separation in 1945. She told the court, 'We agreed that I have the furniture except the wireless, and the house we were renting. I remained in the house and am still there. I have the children and he pays me 30/- per week for the children but no maintenance for myself. He packed his things and left the house'. ${ }^{53}$ In 1916, Annie B. petitioned for a judicial separation on the ground of her husband's cruelty. They married in Wellington in 1873 and had nine children together. While there is no evidence she secured her judicial separation, she did obtain a maintenance order. The Registrar's report of February 1917 stated,

The respondent has declined to make over to his wife any of his freehold property which on his own showing is worth a net value of $£ 3320$. The petitioner is 64 years of age and is without any private means and is entirely dependent upon her husband for support. The respondent contends that because his wife is at present living with a married son...that 20/- per week is an ample allowance. This may, however, be only a temporary place of residence....Looking at all the circumstances of the separation and the fact that, although there is a large family of the marriage, the respondent is only called upon to support his wife, I therefore recommend that he be ordered to pay alimony pending suit at not less than $27 / 6$ per week. ${ }^{54}$

In August 1918 an order was made that Samuel B. pay his wife 27/6 per week and pay her arrears back to February 1917, totalling £104/10/0. In answer to her husband's petition for divorce on the ground of mutual separation in 1946, Margaret W. alleged he had failed to provide for her and their children an adequate maintenance resulting in his imprisonment. She had then been left to depend upon a widow's benefit as a deserted wife from the Social Security Department. ${ }^{55}$

Women who chose to divorce their husbands, or were divorced by their husbands, were often placed in a difficult financial situation, particularly if they had children. ${ }^{56}$

\footnotetext{
${ }^{53} P$ v $P$, AAOM/W3265/D1973/1945/ANZ-W.

${ }^{54} B \cup B$, AAOM/W3265/D1443/1916/ANZ-W.

${ }^{55} W v W$, AAOM/W3265/D2417/1946/ANZ-W. She would have had to qualify carefully for this benefit.

${ }^{56}$ Margaret McClure, in her oral history study of nine women who divorced in New Zealand during the 1950s and 1960s has identified financial hardship as a common theme for most of the women. See Margaret McClure. "When a Happy Marriage Turns to Custard". Women's Stories of Divorce in the 1950s and 1960s'. Oral History in New Zealand, 18 (2996): 3.
} 
Essentially they had three main options for financially supporting themselves and their children. Firstly, they could seek paid employment or generate an income by running a small business such as a boarding house. Alternatively, they could ask the court to award them maintenance, payable by their former husband, although this often did not cover their costs of living and ex-husbands were notoriously unreliable at paying maintenance. Finally, they could apply for charitable aid, and later for government assistance. Again, this income was minimal, and applying for charitable aid usually involved being 'inspected' and subjected to surveillance. Possibly another option was to seek financial support from family members, but the option which most women probably took was remarriage.

Clearly women who were in paid employment, or were able to obtain paid employment, were at an advantage to those who were not. Having a guaranteed income that was not dependent on a former husband paying maintenance or a charitable aid board approving payment gave women a degree of independence. Unfortunately, the divorce files do not provide much light on the degree to which women who divorced were in paid employment as the vast majority of them listed themselves, or were listed on the divorce petition, as being a 'married woman'. A study of Dutch women born between 1903 and 1937 shows that women in paid employment were more than three times as likely to end their marriages in divorce as those who were not, ${ }^{57}$ and without any figures to the contrary it seems likely the situation was similar in New Zealand. Potentially the stigma of being divorced or being involved in a divorce case could make it more difficult for women (and men at times as well) to seek paid employment. In 1943 one husband told the court, '[a]t that time my wife knew I was going for a divorce. She said that I would not be able to obtain a divorce. Earlier my wife had mentioned that she would get the sack from work if they found out about this ${ }^{58}$ Women were less itinerant than men, so it was more difficult to avoid or escape this kind of moral judgement.

\footnotetext{
${ }^{57}$ Tineke Fokkema and Aart C. Liefbroer. 'Employment and divorce among Dutch women born between 1903 and 1937'. HF 9, no.4 (2004): 439.

${ }^{58} S v S \& M$, AAOM/W3265/D1209/1943/ANZ-W.
} 
Table 4.7

Women's Average Annual Income by Marital Status Compared with the Average Male Income

\begin{tabular}{c|cc}
\hline Marital Status & $\mathbf{1 9 2 6}$ & $\mathbf{1 9 4 5}$ \\
\hline Never Married & $£ 105$ & $£ 140$ \\
Married & $£ 95$ & $£ 85$ \\
Legally Separated & $£ 105$ & $£ 135$ \\
Widowed & $£ 110$ & $£ 95$ \\
Divorced & $£ 120$ & $£ 150$ \\
Not Specified & $£ 100$ & $£ 85$ \\
& & \\
\hline Average Male Income & $£ 205$ & $£ 310$ \\
\hline
\end{tabular}

Source: New Zealand Census 1926, 1945.

Being refused employment because of their involvement in a divorce case was not the only problem women faced. Women, and particularly married women, did not enter the workforce on the same basis as men. ${ }^{59}$ Women were paid substantially less, marriage bars existed for women in many occupations throughout most of the study period, and generally women were assumed to have a man, whether it be a husband or a father who supported them financially. ${ }^{60}$ During the interwar period, New Zealand had one of the lowest rates of married women in paid employment among western countries. ${ }^{61}$ While paid employment for single women became the norm between 1870 and 1939, it was not until after 1939 that married women's employment was normal. ${ }^{62}$ Table 4.7 shows while the average divorced woman earned more than other women, the difference was not substantial, and was significantly less than what the average man earned, both in 1926 and 1945. Equal pay was only introduced in the public sector in 1960 and not across the private sector until 1972 - well after this study finishes. Melanie Nolan has argued however, it was between 1939 and 1960 that women's wages as a proportion of men's wages grew the most - rather than subsequently under equal pay legislation - as a result of the demand for their labour. ${ }^{63}$ During the Depression of the 1930 s men were privileged in

\footnotetext{
${ }^{59}$ Caroline Daley briefly discusses the type of work married, separated and divorced women undertook in her study of Taradale. She highlights the difficulty of waged work for women and argues 'the women who succeeded economically usually inherited a business or other assets'. See Girls \& Women, Men \& Boys. Gender in Taradale, 1886-1930. Auckland: 1999, 68-69.

${ }^{60}$ For example see, Jo Aitken. 'Wives and Mothers First: The New Zealand Teachers' Marriage Bar and the Ideology of Domesticity, 1920-1940'. Women's Studies Journal 12, no.1 (1996): 83-98.

${ }^{61}$ Nolan, 'Constantly on the Move', 361.

${ }^{62}$ Ibid., 360.

${ }^{63}$ Melanie Nolan. 'Unstitching the New Zealand State: Its Role in Domesticity and its Decline'. International Review of Social History no.45 (2000): 267.
} 
relief schemes because of their assumed domestic responsibilities and women had to pay unemployment taxes, but did not receive the same benefits as men. ${ }^{64}$

Divorce might lead to destitution for the wife, even for those with vocational training. In September 1923, after divorce due to her adultery, Edyth D. petitioned the court for maintenance. Her former husband had paid her maintenance of $£ 2 / 10 /-$ per week until the granting of the decree nisi in May 1923. Edyth stated,

That the Petitioner has no means whatever and has at various times since the said 18th day of May 1923 been forced to sell various private belongings for the purpose of maintaining herself and at the present time she is dependent on friends for her upkeep and support. That the Petitioner was prior to her marriage a Nurse in England but she has not qualified or registered in New Zealand though on occasions she has obtained employment as a Nurse. Subsequent to the making of the decree nisi herein the Petitioner has obtained employment on three different occasions but on its being discovered that she was the Respondent in the above divorce suit she has been summarily dismissed from the employment and she considers that it would be impossible for her to obtain any settled employment as a Nurse in New Zealand. ${ }^{65}$

In 1925 in response to her husband's petition for divorce on the ground of adultery, Margaret A. claimed after a Deed of Separation had been entered into in 1924 her husband had failed to pay the maintenance leaving her 'destitute and penniless'. In May 1926 a decree absolute was granted on the ground of the wife's adultery but unlike most adultery cases, the husband was ordered to pay 25 shillings maintenance per week until the respondent was able to support herself. This was no doubt an acknowledgement of the numerous acts of cruelty and failure to maintain that the respondent had alleged in her answer to her husband's petition. ${ }^{66}$ Economic problems were also an issue for Vera C. After receiving a divorce in 1950, she wrote to the New Zealand Supreme Court, 'Can you please help me regarding my remittance money order, you ordered my husband to pay for my child'. She explained that she had returned to England with her husband's consent and had 'nowhere to live only at the YWCA and am separated from my child. I am attending hospital and am badly in need of money ${ }^{67}$ As these cases suggest, divorce left some wives in poverty.

\footnotetext{
${ }^{64}$ Nolan. 'Unstitching the New Zealand State', 259.

${ }^{65} D v D$, AAOM, W3265, D2407/1923, ANZ-W.

${ }^{66} A \cup A \& O$, AAOM, W3265, D2821/1925, ANZ-W.

${ }^{67} C v C$, AAOM, W3265, D205/1947, ANZ-W.
} 
For divorced women, charity became one means of support, but this often involved meeting the test of 'deserving' behaviour. ${ }^{68}$ Throughout this period, in concert with the increasing state financial provision of social welfare, there was a growing need to have marriage formally terminated in order to ensure eligibility for state support and to ensure future children would be legitimate. ${ }^{69}$ Divorced women found gaining access to state benefits difficult due to the 'clear hierarchy' that Margaret Tennant has discovered existed for women 'without male support'. According to Tennant, at the bottom of this moral hierarchy were 'immoral women such as single women. Deserted wives rated somewhat higher and were less likely to be regarded as authors of their own fate. The most deserving applicants of all were widows, both older women and those with dependent children'. ${ }^{70}$ Divorced women might have found it difficult to gain such aid depending upon the factors causing their divorce.

Moral judgements were clearly present in the activities of New Zealand charities. In 1893 the Society for the Protection of Women and Children (SPWC) was formed in Auckland, and in 1897 a branch was set up in Wellington to provide a source of support for 'women who had been cruelly treated' and 'neglected children'. ${ }^{71}$ Women wanting to separate from their husbands or those who had experienced poverty following a divorce might turn to the SPWC for support. Initially it expressed its disapproval of the 'ambiguous status' of single mothers and thought deserted wives 'carried some degree of blame for their destitute condition'. ${ }^{72}$ For example the SPWC minute book on 13 August 1901 recorded the Committee had refused to give a woman aid to gain a legal separation as she refused to live with her father and preferred to live 'an idle life in town'. ${ }^{73}$ At the same time, the

\footnotetext{
${ }^{68}$ Margaret Tennant. Paupers and Providers: Charitable Aid in New Zealand. Wellington: 1989, 103.

${ }^{69}$ A similar trend has been noted in England and Wales from 1906. See Griselda Rowntree and Norman H. Carrier. 'The Resort to Divorce in England and Wales, 1858-1957'. PS 11, no.3 (1958): 192.

${ }^{70}$ Tennant, Paupers and Providers, 105-106.

${ }^{71}$ Janet November. In the Footsteps of Ethel Benjamin. New Zealand's First Woman Lawyer. Wellington: 2009, 75. For further details of the Auckland branch of the SPWC see, F.J. MacCuish. 'The Society for the Protection of Women and Children 1893-1916'. Research essay, University of Auckland, 1983; Margaret Tennant. 'The Decay of Home Life? The Home in Early Welfare Discourses', in At Home in New Zealand. History, Houses, People, ed. Barbara Brookes. Wellington: 2000, 24-40; Raewyn Dalziel. Focus on the Family. The Auckland Home and Family Society, 1893-1993. Auckland: 1993. For the Dunedin branch see Susan Lee Chivers. "“A Man's Home is His Castle”: Domestic Violence in Dunedin, 1888-1914'. BA(Hons) research essay, University of Otago, 1988, 74-80; Jane Green. 'The Society for the Protection of Women and Children: Dunedin Branch, 1914-1945'. BA(Hons) research essay, University of Otago, 1982; Melissa L. Reid. 'The Society for the Protection of Women and Children: Dunedin Branch, 1899-1914'. BA(Hons) research essay, University of Otago, 1981.

72 Tennant, Paupers and Providers, 108.

${ }^{73}$ Minute Book, 13 August 1901-23 September 1904, qMS-1561, 3.
} 
SPWC criticised husbands who avoided their responsibilities and abandoned their wives and children. ${ }^{74}$

Attitudes however, changed over time. The SPWC began to provide aid to wives seeking separations. ${ }^{75}$ In the summary of cases for the SPWC in 1927-1928, there were a total of 248 cases involving 429 children. There were only two cases relating specifically to divorce, involving four children. There were also six cases involving alleged desertion, 38 requiring 'advice', another 43 involving 'advice and help', three involving maintenance, seven for enforcing maintenance orders, 32 about separation and maintenance, two for separation, one for assault, two for reconciliation, 10 for custody, 21 for alleged cruelty, four for variation of maintenance order. ${ }^{76}$ The SPWC sought to ameliorate the situation so deserted wives could receive an allowance. ${ }^{77}$

State provision displayed a similar hierarchy in the administration of Widows Allowances which began in 1911 and the Family Allowance in $1926 .{ }^{78}$ The state system made no provision for women with 'no good reason' for being without a breadwinner. It frowned on unmarried mothers and deserted wives, assuming fault on their part, and extending its aid at first only to 'blameless' widows. ${ }^{79}$ Consequently, deserted wives could not receive a pension until 1936, and a solo mother's benefit 'by right' was not introduced until 1973. ${ }^{80}$ Such provisions remained controversial and the status of women without a husband and children without a father remained ambiguous leading to public criticism of any entitlements for deserted women, due to a fear of 'affirm[ing] family dissolution'. 81 In contrast, the Industrial Conciliation and Arbitration Amendment Act 1936 reinforced the male breadwinner identity, by specifying the male adult wage rate be based on the income a husband required to support a wife and three children. ${ }^{82}$

\footnotetext{
${ }^{74}$ Tennant, Paupers and Providers, 109.

75 Tennant. 'The Decay of Home Life?', 32.

${ }^{76} 31^{\text {st }}$ Annual Report 1927-1928, pp.5-6, Annual Reports 1919-1931, MSX-3293.

${ }^{77}$ SPWC $31^{\text {st }}$ Annual Report 1927-28, p.8, Annual Reports 1919-1931, MSX-3293.

${ }^{78}$ Widows' Pensions Act 1911 (2 GEO V 1911 No.16); Family Allowances Act 1926 (17 GEO V 1926 No. 30). For details of the Family Allowance see Melanie Nolan. Breadwinning. New Zealand Women and the State. Christchurch: 2000, 137-64.

${ }^{79}$ For a recent study of deserted women in New York, and the provision of welfare see, Anna R. Igra. Wives Without Husbands. Marriage, Desertion, \& Welfare in New York, 1900-1935. Chapel Hill: 2007.

${ }^{80}$ Nolan. 'Unstitching the New Zealand State', 259.

${ }^{81}$ Margaret McClure. A Civilised Community. A History of Social Security in New Zealand 1898-1998. Auckland: 1998, 67.

${ }^{82}$ Robert Chapman. 'From Labour to National', in The Oxford History of New Zealand, $2^{\text {nd }}$ ed. ed. Geoffrey Rice. Auckland: 1992, 356. Ben Schrader has argued that the First Labour Government's housing policy,
} 
As this analysis has demonstrated, working class couples more frequently divorced than middle class couples. This reflects the economic insecurity and consequence tensions of working-class life but also the more egalitarian legal and marital arrangements in New Zealand which made it easier for poorer men and women to secure a divorce. The middle and upper classes had a greater financial incentive to remain married and risked losing their reputation, and perhaps damaging their professional prospects in the case of men, by seeking a divorce, a risk which working people did not face given their greater mobility and lesser status. Instead, divorce offered the advantage of allowing them to remarry, in keeping with their own notions of respectability in New Zealand. In smaller communities, which were most common in New Zealand during the study period, it was harder to pretend to be someone else, take on a new identity, or form a common law relationship in contrast to the greater anonymity of Britain or the United States. Commitments to different models of class-based respectability thus militated against divorce for the middle and upper classes while making it a desirable and economically affordable solution for New Zealand's working class.

outlined by John A. Lee in 1936, was supportive of 'prescriptive gender roles'. See, Ben Schrader. 'Labour at Home. The First Labour Government and the Familial Suburban Ideal', in At Home in New Zealand. History, Houses, People, ed. Barbara Brookes. Wellington: 2000, 125-39. On the promotion of the domestic ideal by the Labour Government see, Maureen Molloy. 'Citizenship, Property and Bodies: Discourses on Gender and the Inter-War Labour Government in New Zealand'. G\&H 4, no.3 (1992): 293-304. 


\section{Chapter Five}

\section{Privacy, Prurience and Publicity: Suspicions and Surveillance in the Divorce Proceedings}

During the first half of the twentieth century surveillance played a part in obtaining a divorce on the ground of adultery in New Zealand. Such cases, which included a significant amount of surveillance presented as evidence in court, usually involved contested adultery allegations where the respondent and co-respondent denied the charge of adultery. The surveillance operated at a number of levels - surveillance carried out by the suspicious spouse normally with assistance from family members and friends, surveillance by professional private detectives, surveillance of the behaviour of the couple as conducted in the divorce proceedings, the coverage of divorce cases by newspapers, like the populist weekly Truth, and gossip, both from those who knew about the couple's affairs and by the readers of the sensational court coverage. Since husbands more often petitioned on the ground of adultery than wives, the newspaper emphasis on adultery cases shaped public perceptions of wives as more likely to 'break' the marital bonds than husbands. This simultaneously punished the 'scarlet woman' and also suggested that women could exhibit sexual desire and pursue their own pleasures, thus helping to sexualise New Zealand women. Although adultery cases became less frequent after 1920 they still made up a significant number of cases heard by the courts, blurring the line between public and private in a way that gave viewers and readers the thrill of titillation and the satisfaction of feeling morally superior to the protagonists involved in a messy situation.

Practices of surveillance were presented in court primarily by the petitioner who gave a narrative, usually starting with the suspicious behaviour displayed by their spouse and then describing the acts of adultery that had been witnessed. The petitioner was followed by other witnesses. If the case was defended all the witnesses were cross-examined. Most cases were heard by only a judge, but on occasions a jury would hear the case as well. Judges, of course, had the opportunity to comment on the case before them and sometimes on the state of marital relationships more generally. For example, in 1945 Justice Blair, sitting in the Palmerston North Supreme Court remarked, 'In my younger 
days this sort of behaviour would have been considered absolutely scandalous, and the woman would have been completely ostracised by society. However, people seem to take a much less serious view of this sort of thing today, a fact which, to me, is lamentable'. 1

Surveillance was primarily carried out by the petitioner. It was usual for the petitioner to explain in court what led to their suspicion being aroused. This narrative of surveillance, deceit and wrongfulness, would include an explanation about the decline of the relationship leading to their spouse leaving the house regularly without a plausible explanation. It was also very useful for the petitioner to have a supporting witness, and often a suspicious husband or wife would ask a family member or friend to assist them in their surveillance of their spouse. For example, Mrs P., who was suspicious of her husband going out all night, followed her husband to a house and observed him and his girlfriend, accompanied by her daughter and son in law. When the husband and girlfriend retired to the bedroom it was difficult to see them, but luckily her son-in-law had brought a ladder and she was able to climb up and see 'their bare arms'. Yet another time Mrs P. and this time her friends went to watch her husband. She said:

We then saw them get into bed together. I then went and got Mrs F[...] She had been sitting out in the car. She looked through the window also. We went back to this house again and there was another room lit up. He had made a cup of tea and taken it into the other room. He then told her to get into bed as we could hear the conversation through the fanlight window. Mrs F[...] then left and came back to her husband. ${ }^{2}$

Family members had often witnessed other behaviour that contributed to the case against the adulterer. This tended not to take the form of active surveillance, but more in the way of passing on information that was obtained in the normal course of everyday life. For example, in 1905 a 16 year old daughter was unpacking her father's bag after his return from holiday and found what was later to be determined as a 'gonorrhoea bag' which she gave to her mother. This became a central piece of evidence in court. ${ }^{3}$

Some spouses found evidence of adultery, which they considered concrete, without actually establishing who their spouse was committing adultery with or when or where this adultery was taking place. Mrs S. told the court in 1906: 'About 6 years ago I commenced going through his pockets. I surmised what the things were I found in the

\footnotetext{
1 'Collapsed On Hearing Judge's Verdict'. NZT, 21 November 1945.

${ }^{2} P$ v $P$, AAOM/W3265/D2513/1946/ANZ-W.

${ }^{3} O v O, \mathrm{AAOM} / \mathrm{W} 3265 / \mathrm{D} 674 / 1905 / \mathrm{ANZ}-\mathrm{W}$.
} 
pockets, \& I asked people who told me what they were'. Her husband refuted her claim and said, 'I will swear that my wife has never found in my pockets sexual preventatives. I have never told her I have had connection with other women'. ${ }^{4}$ In order to enhance her respectability, Mrs S. was careful to make clear to the court that she was not entirely sure what it was she claimed to have found in her husband's pocket. If she had no knowledge of contraceptives, her husband must have been using them with someone else.

When private investigators were hired, part of their job was ultimately to give evidence in court in support of the petitioner. In one case, from 1906, the investigator said he was being paid $£ 30$ for his work, regardless of whether he uncovered any evidence of adultery or not. Although private detectives were used in some cases, this was not the norm. One reason surveillance could be easily carried out by spouses was the small size of Wellington, and also the small size of New Zealand, which rendered individuals easily subject to public scrutiny. It was difficult to avoid being seen or recognised. ${ }^{5}$ Surveillance was relatively easy and almost hard to avoid in such a small society and this made it easier for a petitioner to carry out the surveillance, and reduced the need for a private detective. It seems probable that many men who worked as private detectives had other 'day' jobs as well, especially as most litigants did not have a lot of money to spend on professional assistance.

Sometimes private detectives were used to confirm what the petitioner had already witnessed. In 1906, Annie O. told the court that 'I had some reason to believe he was carrying on with a Mrs A[...]. On two or three occasions I was told about it and to satisfy myself I went to see. ..I saw him coming from his shop down Taranaki St one Saturday evening about eleven o'clock and he went into this house. I know Mrs A[...] by sight - I know she is living apart from her husband, I did not watch very long because I was alone, but I waited about an hour. He did not come out during that time'. ${ }^{6}$ Mrs O. then employed Samuel Free, a private detective, and his assistant Francis Hazelwood, to monitor her husband.

\footnotetext{
${ }^{4} S v S$, AAOM/W3265/D722/1906/ANZ-W

${ }^{5}$ Until the late 1930s almost half of the New Zealand population lived in towns with fewer than 8,000 inhabitants or in rural areas. See Erik Olssen. 'Towards a New Society', in The Oxford History of New Zealand, $2^{\text {nd }}$ ed. ed. Geoffrey Rice. Auckland: 1992, 260. The population of the Wellington urban area, was just under 50,000 in 1901 and had reached almost 150,000 by 1936. The Auckland urban area, the largest in New Zealand, had a population of about 210,000 in 1936.

${ }^{6}$ O v O, AAOM/W3265/D692/1905/ANZ-W.
} 
Samuel Free's name came up frequently in divorce cases, and he and his assistant, Francis Hazelwood, often had their names printed in newspaper reports of divorce cases providing free advertising of their services. ${ }^{7}$ In one case he told the court, 'I have never made a bargain of no cure no pay. I have been at this work off \& on 10 or 11 years. A man did say he would give me $£ 5$ after it was all over $\&$ in that case I received the extra, but I charged my fee....I am experienced in getting up evidence in divorce cases. I have not given evidence in 40 cases - perhaps not three a year'. ${ }^{8}$ Private detectives were often asked about their fees in court in order to determine whether they were paid regardless of the outcome of the trial, or whether they only received payment when a divorce was secured. Clearly this was to establish the likelihood of giving false statements in order to secure a favourable outcome for the petitioner.

Judges challenged evidence provided by private detectives and spouses. In 1903 Justice Connolly sitting in the Auckland Supreme Court refused to grant a divorce in a case where the husband was petitioning on the ground of adultery. The petitioner, a doctor from Otahuhu who was separated from his wife of 20 years, had been told his wife was having an affair so accompanied by a friend, he watched the boarding house where she was living. The Observer reported that 'they watched Mrs Bewes's room until they saw the lights turned down. Then they broke the balcony door open, and found Edward William Jennings, the co-respondent, in his shirt, while Mrs Bewes was lying on a sofa'. Justice Connolly, however, interpreted the situation rather differently. He did not doubt the veracity of Mr Bewes's statement, but refused to grant a divorce as he considered $\mathrm{Mr}$ Bewes's actions connivance. The Observer quoted Justice Connolly's judgment at some length:

It is highly discreditable that a man suspecting his wife of adultery should wait a whole hour in the hope of such an act being committed by her. I say it is conniving at her adultery and I dismiss the case... a man should not do such dirty work as to watch outside a window for an hour in the hope of catching his wife doing wrong. ${ }^{10}$

The Observer was outraged by the decision stating:

\footnotetext{
7 'Local and General'. EP, 6 December 1904; 'Divorce Court'. EP, 21 August 1907; 'Divorce Court'. EP, 6 September 1909; 'Divorce Court'. EP, 10 March 1910; 'Divorce Cases'. EP, 21 May 1912.

${ }^{8} S v S$, AAOM/W3265/D722/1906/ANZ-W.

9 'An Extraordinary Judgment. Mr Justice Connolly and the Bewes Case'. Observer, 7 March 1903.

${ }^{10}$ Ibid.
} 
the Judge refuses to accept the testimony of a private detective, he sets aside the proof offered by the husband, and practically tells flighty wives that they are free to carry on their amours in spite of all the private detectives and husbands in the country....Also seeing that the husband was paying for the woman's maintenance, he was entitled to expect her to live a moral life, and, if her conduct was such as to establish that fact, and release himself from his encumbrance, except by watching her? ${ }^{11}$

The case was appealed, and in March 1903 the Court of Appeal overturned Justice Connolly's decision. ${ }^{12}$

Charitable organisations sometimes became involved in the monitoring of individuals and families and operated as a form of social control, as they were able to provide 'expert' testimony in court. ${ }^{13}$ For example, the Society of Protection of Women and Children's minute book on 10 September 1901 read: 'the Algar divorce case being heard today in Court - Lecky had been subpoena as a witness as to Mrs Algar's drunkenness'. ${ }^{14}$ The same organisation argued in its annual report in 1928-1929 'all matrimonial, maintenance and affiliation cases shall be heard under the same conditions as obtain in Sydney i.e. a private room where only the Magistrate, necessary officers of the Press, social service workers, justices, and those immediately concerned are admitted'. ${ }^{15}$ This would suggest that while the SPWC supported 'experts' and those in some position of authority or power hearing matrimonial disputes, the organisation did not support the general public having direct access to the courts; rather they should be able to read about the cases in newspapers.

After 1898 the law did not treat adulterous husbands differently from adulterous wives, but there was still a widespread view in New Zealand society that adulterous wives had committed a greater transgression than their male counterparts and this was apparent when petitioners explained what prompted their suspicions to begin with. Husbands generally behaved much more suspiciously than wives before their wives began to actively carry out surveillance. The greater tolerance of husbands' behaviour that was seen as non-conducive to happy marital life, but not necessarily leading to adultery, such

\footnotetext{
11 Ibid.

${ }^{12}$ Bewes $v$ Bewes and Another, [1903], NZLR, 665.

${ }^{13}$ For examples see, $B v B \& C$, AAOM/W3265/D2135/1921/ANZ-W; $B v B$, AAOM/W3265/D353/1940/ ANZ-W; $F v F$, AAOM/W3265/D1125/1943/ANZ-W.

${ }^{14}$ SPWC Minute Book, 13 August 1901-23 September 1904, qMS-1561, 7.

${ }^{15}$ SPWC Annual Report 1928-1929, 6, Annual Reports 1919-1931, MSX-3293.
} 
as staying out late and drinking excessively, illustrates expectations about how wives and husbands should behave.

What prompted the petitioner to carry out surveillance when this would often be reported in newspapers and both the petitioner and respondent would be named? To do so invited public humiliation, shame and gossip. The existence of a number of easier routes to divorce suggests couples may have been using the risks of public exposure as a weapon in the bitter conflict that ended up in court. Certainly the exchange between Mr and Mrs B. suggests each used the weapon of public scrutiny against the other. The divorce of $\mathrm{Mr}$ and Mrs B demonstrates the use of surveillance in its many forms. On 30 April 1921 William B., an estranged New Zealand husband, wrote to his wife whom he was accusing of adultery, and said their son Allen 'is not the big stupid that you tell everybody he is. He noticed more than you think. You know you told him when you started sitting over in the cowshed with $\mathrm{C}[\ldots]$ that if he told anything he saw you would kill him. He saw more than you think'. The husband then used this information gathered by Allen to threaten his wife,

If you are wise you will give up the boys without a fuss; although I would like to get you in Court to show you up. .... I am going to send C[...] a list of all the men you misbehaved with before and after marriage, because I don't think you let him know, and then he will see what a prize he has got... I hear you have been at it since fifteen and now over 40 in disgrace, in the family way. You are about the hottest woman for men I ever heard of. It is a wonder I did not catch that disease off you and am lucky to escape so easily. ${ }^{16}$

All letters Mr B. wrote to his wife were presented in Court, before a jury, and were archived in the divorce file, although they were not referred to in newspaper reports. Mrs B. threatened a different kind of surveillance in a response to her husband warning him, 'Do not go rash and as far as talking of divorce, I always thought you did not want your name in print'. Both $\mathrm{Mr}$ and Mrs B. clearly understood the weapon that surveillance might offer them in their conflict that eventually ended up in the divorce court.

Some of this surveillance occurred because of the legislative requirements establishing the legal grounds for a divorce. It had to be demonstrated that a spouse had violated his or her role in a fundamental way to obtain a divorce. This requirement to apportion blame for a failed marriage sometimes made surveillance necessary to acquire the required proof. Since adultery was generally considered to be the most potent instance of a failure to

${ }^{16} B \vee B \& C$, AAOM/W3265/D2135/1921/ANZ-W. 
meet the requirements of marriage, those respondents whose marriages were dissolved on the ground of their adultery received the most serious penalties from the courts of all marriage violators. Seeking to avoid the risks of exposure, adulterers often went to some lengths to deceive their spouse. As a result, the most active forms of surveillance might be used when the most active deception was taking place. In the court itself, the behaviour of the couple came under additional scrutiny blurring the boundary between the intimate and the visible. Private letters came to the attention of the court as evidence and remained in the divorce file.

Those intent on divorcing their spouse knew about the need to provide evidence to the court of the marital wrong which had occurred. In 1939 Elizabeth M. discovered her husband was having an affair and confronted him. He admitted to the relationship and Elizabeth, in retelling her story to the court, replied, "If that is so I want you to say that in front of a witness." I took a friend, a Mrs P[...], along with me. He admitted having committed adultery with Emily P[...] of Christchurch. I said that I wanted it in black and white and that is the paper that he gave me. Mrs P[...], my husband and I signed that paper'. ${ }^{17}$ Elizabeth knew her word alone was not enough to secure a divorce on the ground of adultery, and by having a witness as well as a signed confession, she made the process of obtaining a divorce much easier.

Wives who did not want their husbands to know where they were going when they went out would often lie rather than refuse to answer the question. In April 1940, for example, David J. told the court how he discovered that his wife was committing adultery:

Towards the latter part of last year I was suspicious about my wife going out with someone. On November $2^{\text {nd }}$ and $23^{\text {rd }}$ I followed her. I had not spoken to her about going out. On November $2^{\text {nd }}$, she told me she was going out with a girl with whom she used to work, and I rang up my father and got a car. I followed her in a car and saw her meet someone at the bottom of the street and they went up into the bushes. I now know that the man was the corespondent. On November 23, I followed her. My father, eldest brother, and taxi driver were with me...We waited at the bottom of Homewood Avenue and she passed with the co-respondent. They went into a shed in Waikari Street. We waited eight or nine minutes. They were on the floor and the corespondent had the buttons of his clothes undone and she had her clothes up round her waist. She admitted then that they had committed adultery. ${ }^{18}$

\footnotetext{
${ }^{17} M v M$, AAOM/W3265/D5493/1939/ANZ-W.

${ }^{18} J v J \& H$, AAOM/W3265/D5701/1939/ANZ-W.
} 
Again this case shows the need to have witnesses who were not only able to provide testimony to the court, but also their presence at the moment of exposure reinforced the humiliation involved. David J., like Ada P., had an advantage over many other spouses who were trying to watch and monitor their partners. Both David and Ada were still living with their spouses and so had many opportunities to observe their behaviour. In contrast, most husbands and wives who petitioned for divorce on the ground of adultery were living apart from their spouses, and sometimes in different towns or cities, or even in different countries, making the process potentially more difficult. In another case, Gilbert C. told the court in April 1946 that shortly after his marriage to Edna W. in September 1940 he went overseas with the armed forces and did not return until April 1945. On his return he lived with his wife for about two weeks before she left him. He then said,

[a]s a result of what I had been told by the proprietor of the house [where his wife was living] I decided to keep it under some sort of observation. I went to the house one night with a friend. A few days later I got another ring from the proprietor and I went to the house. There was a car outside the house and there was a tallboy in the back of the car. I saw S[...] enter the car and also my wife got into the front. I spoke to S[...] about this and he said, "Well I have got plenty of money I'll do the decent thing". 19

While Gilbert did not have the advantage of observing his wife day to day, the fact she was living apart from him made it possible for her to live with another man and therefore relatively easy to 'catch' her, without actually finding her in flagrante delicto, especially seeing he had the assistance of her landlord.

There were a number of different signs of intimacy that led to suspicion. For example being with another person in a room with no lighting was considered suspect, and both spouses and private investigators went into detail about lights being turned on and off. This was because if the 'watcher' entered the room and the light were off, it made it difficult for that person to give precise evidence about what he or she saw on entering the room. Being seen together in public, and especially walking arm and arm, was also considered very suspect. For women, being seen in public alone with men and especially being seen on a number of different occasions with the same man or associating with men in hotels was offered as evidence. When these men were American soldiers, the evidence carried even more weight. It seems that because Americans were relatively distinctive,

\footnotetext{
${ }^{19} C v C \& S$, AAOM/W3265/D2429/1946/ANZ-W.
} 
particularly in military uniform, women were more likely to be noticed in their company. While it was acceptable to show hospitality towards servicemen, the 'correct' way to do this was by offering a meal or afternoon tea in a private home with both husband and wife present. Women who were continually seen in public with Americans without their husband's consent were criticised. In some cases, the actual co-respondent was a New Zealander, but the fact the wife had also been seen with Americans helped suggest that her behaviour more generally was inappropriate. Other actions that helped discredit respondents included being away from home, particularly at night, having members of the opposite sex in their homes, and referring to people by their first names. Also if conversations could be overheard they were often repeated in court if the topic of conversation was such that it would only be had between close friends or family members.

In July 1946, Ada P. told the court what led her to suspect her husband was committing adultery. She said, 'for some years past there has been worry about my husband's conduct towards me. He has been in the habit of frequently going out at nights and returning late in the mornings. Some nights he did not come home at all. As a result of that I formed the suspicion he was carrying on with another woman'. ${ }^{20}$ That Mr P'.s behaviour had gone on for so long before his wife took divorce proceedings suggests the difficulty wives had in challenging their husbands' behaviour. Husbands could expect to know where their wives were at any time, whereas wives were not entitled to know their husband's movements. Wives who were persistent in asking of their husband's whereabouts were described as 'nagging'.

For some people surveillance became an obsession. Even after gathering enough information to present to the court, they continued in their surveillance. Further, some petitioners' evidence in court was very detailed and included much more information about the demise of their marriage than was necessary to show that adultery had taken place. In 1948 Mr C. who had been watching his wife's house in the evening from March to August 1947, was quizzed by his wife's lawyer in court as to why he watched the house for so many months and why his wife had contacted the police about his behaviour. Mr C. simply said, 'I would have caught her again if I could have'. ${ }^{21}$ The petitioner could shame the respondent in several ways if he or she produced 'evidence' of adultery, using

\footnotetext{
${ }^{20} P \vee P$, AAOM/W3265/D2513/1946/ANZ-W.

${ }^{21} C v C \& H$, AAOM/W3265/D129/1947/ANZ-W.
} 
the term loosely to include proof that families and friends would accept as well as evidence required by the stricter standards of the court. Prior to petitioning for divorce, the petitioner often informed family and friends of their spouse's transgressions. For example, to return to the case of Mr and Mrs B., Mr B. informed his wife that, 'a letter came from your Aunt and I opened it. There was not much in it or I would have sent it on. She evidently thought you was [sic] living a clean life. But I let her know different [sic]' ${ }^{22}$ Informing family members could lead to social ostracism, which in some cases was more upsetting to individuals than the publicity produced by the court case.

Some petitioners, or potential petitioners, relied on community 'gossip' to help gather information and evidence to present in court. A Wanganui husband who suspected his wife of committing adultery offered a reward of $£ 50$ 'for particulars' of her life. ${ }^{23}$ Most petitioners, however, did not have the funds to do this, nor would they want to publicise they were looking for evidence in case their spouse found out. By the 1940s the fear of community ostracism had decreased. In 1943, May H. wrote to her husband Fred, who was serving overseas, to tell him that she was having an affair. She wrote, 'I suppose I shall forfeit my right to our children, that is the only thing that is worrying me, because all the talk will only be a nine day wonder'. ${ }^{24}$ It is possible that May H. underestimated how long her personal life would be discussed by her neighbours or the possible social ostracism that would accompany such gossip, but the potential threat of gossip and scandal as a mechanism of social control had lost much of its power by the 1940s.

Sometimes, although not often, the police were involved in surveillance of sexual activity which contributed to the case against the respondent. Normally the police had been monitoring a person - usually a woman - without any knowledge of their marital status, but because their sexual behaviour deemed them to be considered, at best, promiscuous and at worst, prostitutes. Once a woman was convicted of prostitution related crimes, such as soliciting and brothel keeping, it was very easy for her husband to divorce her. However, not all promiscuity was considered in the same light and certain women were targeted more than others. For example, in 1944 a police officer, assigned to the AntiVice Squad in Wellington, was monitoring Mrs C., a Polynesian-Chinese woman, when

\footnotetext{
${ }^{22} B v B \& C$, AAOM/W3265/D2135/1921/ANZ-W.

23 'A Wanganui Divorce Case. Interesting Evidence About Private Detectives'. EP, 3 June 1897.

${ }^{24} H v H$, AAOM/W3265/D1017/1943/ANZ-W.
} 
she was living 'at a house in Cuba St - a reputed house of ill fame'. ${ }^{25} \mathrm{He}$ was unable to arrest her for any crime, but continued to keep her 'under observation' when she went to live at Haining St - the Chinatown of Wellington. ${ }^{26}$ She lived with two different Chinese men in the street before being arrested for being an idle and disorderly person. The police officer informed the court that Mrs C., a 35-year-old woman, had been living with a Chinese man of 68 when she was arrested and that a douche had been found in her handbag. After her conviction, she was remanded for a medical examination and was committed to Porirua Mental Hospital. Three years later, her husband divorced her on the grounds of adultery. ${ }^{27}$ This woman was targeted for two reasons - one, she was not of European descent and secondly, and mostly importantly, she was believed to be having a sexual relationship with a Chinese man. ${ }^{28}$ Had she been living with a Pakeha man it is less likely the policeman would have spent so much time following and watching her. This is not the only example of a non-Pakeha woman being arrested for prostitution related crimes. There are examples in the divorce files of Pakeha women being targeted for such crimes, but comparatively far more Maori/Polynesian women were, although others were imprisoned rather than institutionalized. ${ }^{29}$

\footnotetext{
${ }^{25}$ Mrs C. had a Maori middle name, however she had been born in Honolulu and her name on the 1920 American Census form was different to that listed on her marriage certificate, making it difficult to know whether she was of Maori or Hawaiian descent. Her mother had a Chinese maiden name.

${ }^{26}$ For a history of Haining Street see, Lynette Shum. 'Remembering Chinatown: Haining Street of Wellington', in Unfolding History, Evolving Identity. The Chinese in New Zealand, ed. Manying Ip. Auckland: 2003, 73-93.

${ }^{27}$ C v C, AAOM/W3265/D2741/1946/ANZ-W. Mariah C. (listed as Charlotte C. on her admission to Porirua Hospital and on her death certificate) died at Porirua Hospital in November 1951, at the age of 44, of bronchopneumonia and paraphrenia. For a related discussion of the surveillance of First Nation women in Canada see, Robin Jarvis Brownlie. 'Intimate Surveillance: Indian Affairs, Colonization, and the Regulation of Aboriginal Women's Sexuality'. In Contact Zones. Aboriginal and Settler Women in Canada's Colonial Past, eds. Katie Pickles and Myra Rutherdale, 160-78. Vancouver, 2005.

${ }^{28}$ For a brief history of discrimination against Chinese in New Zealand see, Manying Ip. Dragons on the Long White Cloud. The Making of Chinese New Zealanders. North Shore City: 1996, 106-24; For works that deal with Maori and Chinese in New Zealand see, David Pearson. "The "Majority Factor": Shaping Chinese and Māori Minorities', and Nigel Murphy. "Māoriland" and "Yellow Peril": Discourses of Māori and Chinese in the Formation of New Zealand's National Identity 1890-1914', both in The Dragon and the Taniwha. Māori and Chinese in New Zealand, ed. Manying Ip. Auckland: 2009, 32-55 and 56-88; Jenny Bol Jun Lee. 'Eating Pork Bones and Puha with Chopsticks: Maori-Chinese Constructions', in Unfolding History, Evolving Identity. The Chinese in New Zealand, ed. Manying Ip. Auckland: 2003, 94-112. For concerns regarding Chinese men's association with Maori women, especially regarding miscegenation, see, Barbara Brookes. 'Gender, Work and Fears of a "Hybrid Race" in 1920s New Zealand'. G\&H 19, no.3 (2007): 501-18. Brookes article focuses on the 1920s and the 1929 New Zealand Committee of Inquiry into the Employment of Maori of Market Gardens, but these fears and concerns were still present in New Zealand during the 1940s.

${ }^{29}$ For examples see, $S v S$, AAOM/W3265/D1021/1943/ANZ-W; $W v W$, AAOM/W3265/D1415/1944/ ANZ-W.
} 
Newspapers also played an important part by serving up scandalous reports to eager consumers. As Kristine Ottesen Garrigan explained in reference to Victorian Britain, advances in printing technology meant newspapers could be printed relatively cheaply and increasing literacy rates, which also applied to New Zealand, 'made possible the exposure of unconventional behavior on a scale and with an immediacy completely unprecedented'. ${ }^{30}$ She argues 'as long as deviant behavior (in the broadest sense) remains private and a superficial moral and social order is preserved, scandal does not exist. Such conduct must be made public before it can shock'. ${ }^{31}$ While judges heard divorce cases in open court, the press alerted most people to the details of divorce cases thus contributing to a burgeoning market in scandal. The legal acceptance of the right of the press to publish details derived from the belief that marriage was not only a private contract between two individuals, but was of public concern. The coverage and tone of reporting demonstrated the extent of 'anxieties about moral standards' which 'reflected a deep belief that the roots of social stability lay in individual and public morality, ${ }^{32}$ By offering a way to punish transgressors, surveillance was a necessary instrument in reinforcing the moral standards. It was not until 1958 that the New Zealand Parliament enacted legislative changes to limit the extent to which details of divorce cases could be reported; obviously subordinating issues of privacy to other considerations until then.

Newspapers published stories from the divorce cases heard in court. Adultery cases, where surveillance might be recounted in detail, and cases that were defended were more likely to attract press attention. Contested cases involved more testimony and the crossexamining of witnesses made the whole process more sensational and therefore more appealing to journalists and publishers. Most newspapers reported on divorce cases to varying degrees, but the most well-known and sensationalist stories were printed in New Zealand Truth. ${ }^{33}$

\footnotetext{
${ }^{30}$ Kristine Ottesen Garrigan. 'Foreword', in Victorian Scandals. Representations of Gender and Class, ed. Kristine Ottesen Garrigan. Athens: 1992, 5.

${ }^{31}$ Garrigan, 5.

${ }^{32}$ Jeffrey Weeks. Sex, Politics and Society. The Regulation of Sexuality since 1800. London and New York: $1981,92$.

${ }^{33}$ Mainstream dailies such as the Evening Post were also naming divorcing couples, and making the public aware when their divorce case would be heard. This meant that anyone who wanted to could go to the court and hear the case.
} 
Truth was established in 1905 and was New Zealand's only truly national newspaper during most of the twentieth century. ${ }^{34}$ Truth's circulation was 97,600 per week in mid1928, 'but the economic conditions of the Depression cut sales dramatically'. ${ }^{35}$ Compared to other weekly newspapers it was very cheap, which further reinforced its position as the most widely read newspaper. Until 1928 its banner proclaimed that it was 'The People's Paper'. It was directed at a working class audience and it aligned itself with returned soldiers and opposed middle class 'wowsers'. ${ }^{36}$ Its reputation for publishing scandalous stories meant many people publicly declared that they did not read Truth, although many did read it in private. ${ }^{37}$ Truth attracted readers with headlines, such as 'Sorrowful, Sordid Stories of Sin and Sinners' and 'Soldier Let Down By Faithless Wife'.

Even though Truth was not the only newspaper to publish stories about divorce, the sensationalist language and headlines differentiated it from the mainstream dailies. ${ }^{38}$ Often the same 'factual' information was revealed, but it was the way in which Truth revealed information and the obvious delight that it took in reporting on such stories provoked criticism. While Truth's founder John Norton claimed to have set up the newspaper in opposition to 'wowsers', Joblin argues that Truth 'was just as obsessed with immorality as [wowsers] were. It was closer to the wowser viewpoint than it would have liked to admit'. ${ }^{39}$ There was almost universal agreement that the fear of publicity and exposure was a deterrent to people seeking divorces, and those who were concerned about such public scandal usually named Truth as the paper that concerned them most. Truth very clearly condemned respondents in divorce cases, and in doing so 'reinforce[d] social and sexual conformity in much the same way as the wowsers it despised, and perhaps more effectively than rival papers'. ${ }^{40}$

Unfaithful wives risked greater public condemnation than did husbands. Women who committed adultery while their husbands were serving in the armed forces could face

\footnotetext{
${ }^{34}$ For a history of Truth see Redmer Yska. Truth. The Rise and Fall of the People's Paper. Nelson: 2010.

${ }^{35}$ Richard S. L. Joblin. 'The Breath of Scandal. New Zealand Truth and Interwar Society, 1918-1939'. MA thesis, University of Canterbury, 1990, 28.

${ }^{36}$ Joblin, 29. The term 'wowser' was coined by John Norton the founder and owner of Truth in New Zealand and the various Australian states.

${ }^{37}$ Ibid., 27.

${ }^{38}$ Ibid., 181 .

${ }^{39}$ Ibid., 30.

${ }^{40}$ Ibid., 182.
} 
severe criticism from judges and the press. ${ }^{41}$ This severe response may have been one of the reasons that one newspaper criticized a detective who had made false allegations of adultery against a wife in 1901. The Observer stated, 'Private detectives in family matters - and this is the most despicable kind of private detective work - don't do this sort of thing for the love of it'. ${ }^{42} \mathrm{Mr}$ Wrack, a private detective, had told the court a 'widely improbable' story about the respondent and co-respondent having 'criminal intercourse' in a 'lighted dining room, with the blind up and the door open, and the family and boarders going to and fro as they pleased'. ${ }^{43}$ The jury after only a few minutes decided that adultery had not taken place. The writer then goes on to say, 'The question now arises, in view of the verdict, what recourse Mr Herepath and Mrs Fox have against this private detective Wrack on account of these slanders'. ${ }^{44}$ This demonstrates the consequences that allegations of adultery, particularly against a woman, could have.

The surveillance in divorce cases between 1898 and 1947 was required by the courts, and abetted by the press, but the driving force behind this surveillance also lay in the desires of plaintiffs seeking revenge by publicly shaming their spouses, which was one of the reasons why they chose to obtain their divorce in this manner. Angry or hurt spouses could thus take advantage of the public's thirst for scandal. Surveillance also helped satisfy a personal need to know how and with whom a spouse had betrayed the injured party while serving to humiliate the spouse's illicit sexual partner. Furthermore, a close analysis of divorce case files reveals how the law was practiced and utilised, sometimes in ways not intended by Parliament. While one theoretical advantage for men for divorcing their wives on the ground of adultery was that they would be able to claim damages from the co-respondent, in practice this almost never occurred. ${ }^{45} \mathrm{~A}$ more tangible advantage was that adultery cases could proceed immediately, whereas for most other grounds of divorce it was necessary to wait a specified period. An injured husband could also get revenge for the wounds to his pride and sexual esteem through this mechanism that vindicated his demand for a divorce. The wife could also revenge herself on the 'other woman' thus making scandal an implicit part of the courtroom and personal conflicts that often precipitated the decision to seek a divorce.

\footnotetext{
${ }^{41}$ For further details see Chapter 3.

42 'A Divorce Story. Private Detectives at Work'. Observer, 7 September 1901.

${ }^{43}$ Ibid.

${ }^{44}$ Ibid.

${ }^{45}$ See Chapter 4 for further details.
} 
Conversely, participants in the divorce process sought to limit the publicity surrounding their divorce in a number of ways to escape the odium, the scandal, and the other consequences. Some couples did try unsuccessfully to manipulate the divorce law in order to avoid publicity. In a judgment in August 1922, involving a petition for restitution of conjugal rights, Justice Hosking found against the petitioner. In his judgment, he explained:

[The Petitioner's] Counsel very properly brought to the attention of the Court the fact that the wife was living in adultery with another man and stated that the reason of proceeding in this form, instead of by a Petition founded on the misconduct under which the man would be brought in as a Co-Respondent, was to avoid the publicity of the scandal especially out of consideration for the children....In my opinion it is a misuse of divorce process to sue for a restitution of conjugal rights where the real ground for seeking to dissolve the marriage is the adulterous misconduct of the opposite party. I do not think that the desire, even of the innocent party and that is by no means rare, to avoid publicity, which the ordinary procedure in such a case usually gives to the misconduct, is a sufficient reason for allowing procedure for restitution as a substitute. The influence which the publicity of the scandal arising from adulterous misconduct exerts as a deterrent ought not, I think, without express authority for the legislature, to be allowed by the Court to be weakened. ${ }^{46}$

In other situations involving petitions on the ground of separation of three years or more, it was sometimes obvious adultery had occurred as well, but as long as a separation of three years or more had occurred then such cases were allowed to proceed.

Another way in which people tried to avoid being involved or associated with divorce cases was to lie. In one case heard in Wellington in 1906, the petitioner's lawyer questioned a man giving evidence for the respondent about his name.

Dr Findlay: When did you give up bearing the name of Lockhart? - This morning.

You were known as "John Miles" yesterday? - I was.

When did you first call yourself "John Miles" - About four or five months ago.

And now you have got to tell us why "Alec Lockhart" became "John Miles?"

- Because I did not want my name in the papers.

Four or five months ago? - No.

Why did you not want your name in the papers - I did not want to be mixed up in this case. ${ }^{47}$

\footnotetext{
${ }^{46} A v A$, AAOM/W3265/D2271/1922/ANZ-W.

47 'Divorce Court. A Wellington Case'. EP, 12 February 1906.
} 
While this witness was caught out evading exposure, there may have been others who were not. Admittedly, it would be much more difficult for the couple involved to lie about their name, as they had to produce their marriage certificate, but the situation shows how even being a witness in a divorce case was considered undesirable.

Erring spouses tried to make the divorce process as easy as possible so the conflict was not exacerbated and to avoid adverse publicity. In April 1925, for example, Winnie M. wrote to her husband Charles to tell him that she had committed adultery. She gave him very specific information concerning the adultery, detailing exact dates and locations. This information was presumably offered in order to make petitioning for a divorce as straightforward as possible for Charles M. At the same time Winnie also requested her husband 'refrain from using $\mathrm{Mr} \mathrm{K} \mathrm{[...]'s} \mathrm{name.} \mathrm{This} \mathrm{is} \mathrm{a} \mathrm{big} \mathrm{request} \mathrm{I} \mathrm{know,} \mathrm{but} \mathrm{as} \mathrm{it} \mathrm{is}$ our intention to marry just as soon as I'm in a position to do so, I ask it for my future happiness for we love each other and I would like to start off right when the time does come when I shall be free to re-marry'. ${ }^{48}$ Her husband ignored her request and petitioned for divorce on the ground of adultery, naming Cordner K. as the co-respondent. In a communication from a husband's solicitor to his wife's solicitor in 1942, it was suggested that, 'if the wife sees fit to take any proceedings against her husband, to save embarrassment, we can arrange for our client to be at our office at any convenient time for the purpose of service of any documents, ${ }^{49}$ On 9 January 1945, Irene A. wrote to her husband, who was serving in the armed forces, telling him she had contracted venereal disease. She wrote 'I thought if you got a divorce on grounds of adultery it would save a lot of scandal'. ${ }^{50}$ It is unclear how Irene A. thought a divorce on this ground would avoid scandal, other than freely admitting to the adultery removed the need to introduce to the court the fact that she was suffering from venereal disease. Some angry spouses, however, clearly preferred to risk public scandal to punish their spouses. Both surveillance and scandalous revelations in court reflected this need to blame, shame and to seek revenge.

Judges could also shelter the details of divorce cases. From New Zealand's first divorce law in 1867 judges had the right to hear cases in Chambers. ${ }^{51}$ In 1898, judges were also granted the right to 'make an order forbidding the publication of any report or account of

\footnotetext{
${ }^{48} M v M \& K$, AAOM/W3265/D2733/1925/ANZ-W.

${ }^{49} S v S$, AAOM/W3265/D653/1942/ANZ-W.

${ }^{50} A \cup A$, AAOM/W3265/D2353/1945/ANZ-W.

${ }^{51}$ Divorce and Matrimonial Causes Act 1867 (31 Victoriae 1867 No. 94) section 53.
} 
the evidence or other proceedings therein, either as to the whole or any portion thereof' ${ }^{52}$ In August 1900, Mary C. filed an affidavit requesting her petition for divorce on the ground of desertion, drunkenness and failure to maintain be heard in chambers, and any publication of the proceedings be prohibited. She had married her husband in November 1877, and had four daughters, who in 1900, were aged between eight and twenty-two. She argued:

That the respondent has ever since the month of May 1895 lived separate and apart from me and that fact that he is really in existence is I verily believe unknown to my said daughters. That it would be a great grief to each of my four daughters if they were to learn that their father is still alive and to hear of the present proceedings and the unhappy circumstances which arose out of my marriage with him. That my four daughters are in a comfortable position of life and I am believed to be a widow. It will be very detrimental to their prospects in life and social position if a knowledge of the unhappy circumstances involved in these proceedings becomes public property and in their interests and also in the interests of public morality I desire that an Order be made for the trial of this suit in Chambers and prohibiting the publication of any report of or reference to this suit'. ${ }^{53}$

The following year, Jean M. also applied to have her case against her husband heard in Chambers. She argued, 'the evidence on which I rely...in this suit is of a revolting nature and such as in the interest of my family of young children as well as of public morals ought not to be given in open Court seeing that no public benefit can possibly be gained thereby and much lasting harm can be done to me and my children if the private life of myself and the Respondent is laid bare to the public'. ${ }^{54}$ While both of these examples argue the application is in the interest of 'public morality' it is clear that the real concern lies with protecting children from any social ostracism they may result from being associated with a divorce trial.

In the Wellington Divorce Database, there were very few orders for cases to be heard in chambers. Normally such orders were in response to a request by one of the litigants, but in one 1905 case, Chief Justice Robert Stout made an order that the case be heard by a jury in chambers. ${ }^{55}$ All the cases heard in chambers were done so before 1910. Despite this in 1910 Truth complained that cases were being heard in camera unjustifiably and

\footnotetext{
${ }^{52}$ Divorce Act 1898 (62 VIC 1898 No. 42), section 22.

${ }^{53} C v C$, AAOM/W3265/D354/1900/ANZ-W.

${ }^{54} M v M$, AAOM/W3265/D426/1901/ANZ-W.

${ }^{55} O$ v $O$, AAOM/W3265/D674/1905/ANZ-W.
} 
claimed that judges were granting divorces with little real evidence. ${ }^{56}$ On the other hand, in 1926 Truth criticised a judge for not suppressing the name of a respondent being divorced on the ground of insanity. Truth felt the woman's name should have been suppressed even though the nature of her insanity was alcoholic dementia because there were two young children involved. The article stated, '[n]eedless to say the Press generally, and "New Zealand Truth" in particular, refused to publish the name at all' ${ }^{57}$ This was a rare moment, however, as Truth usually showed no qualms about publicising details that could increase its sales.

In 1928, Truth made clear that it was determined to publish divorce details as a public service. It complained wealthy people were manipulating the judicial system in order to reduce the publicity surrounding their divorce cases. In one situation, the newspaper claimed a case was heard by the court, 'at an unearthly early hour when most pressmen were not yet even contemplating breakfast ${ }^{58}$ In other situations it was claimed that the editors of daily newspapers were approached and asked not to publish details of certain divorce cases. According to Truth 'a great many pleas for suppression succeed'. ${ }^{59}$ The following year, there was another report of an individual trying to reduce the publicity of his divorce. This involved Dr Christie of Wanganui who, after having 'hornswoggled' the Wanganui Herald and the Chronicle into not publishing any reports of his divorce, he approached 'practically every newsagent in Wanganui' and offered to buy every copy of Truth, the only newspaper to publish details of his divorce. ${ }^{60}$ The majority of newsagents refused, even after a second offer to buy the newspapers at twice their retail price. Truth responded by sending someone to Wanganui with 500 extra copies of the newspaper to ensure that everyone who wanted a copy of the paper was able to purchase one. In this report, Truth portrays itself as a defender of the 'truth' and sees its role to challenge those whose position or income could potentially allow them to keep their divorce 'quiet'.

\footnotetext{
56 'The Cloak of “In Camera.” Is the Course of Justice Perverted?' NZT, 17 December 1910.

57 'Demented Mother Divorced. Judge Refuses to Suppress Her Name for Children's Sake'. NZT, 4 November 1926.

58 'Hush-Hush Divorce. How Wealthy People Dodge Unwelcome Publicity. Is Silence For Sale?' NZT, 1 March 1928. In another case reported in the Evening Post, it was claimed that the doors of the Auckland Supreme Court were locked by court officials while a police officer was obtaining a divorce. See, "Were the Court Doors Locked? During Hearing of a Divorce Case'. EP, 24 November 1920.

59 'Hush-Hush Divorce. How Wealthy People Dodge Unwelcome Publicity. Is Silence For Sale?' NZT, 1 March 1928.

60 “"Truth” Will Out! Dr. Christie and His Friends' Vain Attempts To Prevent Sale of Papers In Wanganui. Divorce Case Report Causes Stir'. NZT, 7 March 1929.
} 
Truth did acknowledge the scandalous divorces of wealthy people attracted more attention. It demonstrated this in its lavish coverage of celebrities. Most commonly there were reports of the marriages and divorces of Hollywood stars, and as Joblin argues, in Truth 'Hollywood's highly publicised liberal sexual code was represented as a complete abrogation of the sexual values of "decent" society. "Movieland" was a den of decadence and excess, immoral because of its rate of divorce and lack of children'. ${ }^{61}$ The second divorce of New Zealander turned Hollywood star Nola Luxford was covered in the international press and in the New Zealand press in 1937. Luxford was very much aware of the scandal a divorce could cause after her parents' marriage ended in divorce in 1919 when her father, Ernest Pratt, eloped with Rubina Vesty. ${ }^{62}$ At the time of her own divorce, in July 1937, Truth reported under the headline, 'Nola Luxford. Preferred Night Life, Says Husband', that:

Accusing Miss Luxford of having "luxurious ideas", even beyond his income, Bauernschmidt declared his wife remained with him only two days when they moved to Laguna Beach to economise, insisting that she return to Hollywood. Bauernschmidt failed the original action for divorce against the actress, accusing her of having an "extremely bad temper." She retaliated with a cross complaint seeking 500 dollars a month separate maintenance allowance, insisting that he was the violent tempered one. ${ }^{63}$

While the case involved a couple with an enormous income compared with most divorce litigants in New Zealand, the story embodied many of the stereotypes about the sort of unacceptable behaviour of 'modern' women. Luxford's love of dancing and luxury was in opposition to the expectation that women, and especially wives, be self-sacrificing and be primarily concerned with the welfare of their husband and children (Luxford had no children).

The multi-levelled forms of surveillance, including those individuals seeking divorces, detectives, courts and the press were important elements in the divorce process as it occurred in New Zealand. A debate in Parliament about potential changes to protect the privacy of the divorcing couple made clear press scrutiny was as much a part of the

\footnotetext{
${ }^{61}$ Joblin, 192-93.

${ }^{62}$ The Pratts lived in Hastings, which in 1919 was a small community of about 8,000 people. See Pratt $v$ Pratt, AAOW/W3846/D1919/15/ANZ-W.

63 'Nola Luxford. Preferred Night Life, Says Husband'. NZT, 23 July 1937. This was Luxford's second divorce. She married once more in 1959 and the marriage lasted until the death of her husband in 1977. See Carole van Grondelle. 'Luxford, Nola 1895-1994'. DNZB, Updated 7 April 2006, URL: http://www.dnzb.govt.nz/. For a more in depth study of Luxford's life, including her parents' divorce see Carole van Grondelle. Angel of the Anzacs. The Life of Nola Luxford. Wellington: 2000.
} 
surveillance as the other officially mandated forms of scrutiny, investigation, interrogation and observation. Essentially the press operated as a court of public opinion. Parliamentarians were divided into two main groups on the issue of newspapers' rights to publish details of divorce cases. The passing of the Judicial Proceedings (Regulation of Reports) Act in 1926 in England precipitated the debates. The style of English reporting of divorce cases has been described as intensely voyeuristic and obsessively detailed, [writing] adultery as a domestic detective story; the goal for judge, jury, and reader alike is to read the signs by which adultery betrays itself, to determine the truth of this uniquely domestic crime'. ${ }^{64}$ In examining the English Act of 1926, which was the 'first governmental restriction of newspaper reporting of judicial proceedings' in the United Kingdom, ${ }^{65}$ Gail Savage has argued '[o]ne crucial and salient feature of the modern state consists in the institutionalized mechanisms to regulate sexuality and family life. As this process alienated (or liberated) the individual from the informal and local pressures and ties that had previously served this function, its success depended not only upon the conformity of the individual to the law, but also the individual's stake in particular sexual identities'. ${ }^{66}$ As the population urbanised and was subject to less informal regulation by the local community, the power of the press to publicise immorality and clarify expected behaviour through this process became increasingly important. At the same time, press stories were meant to be a warning to the public and it was when it became clear that the readers of these divorce stories enjoyed the 'cautionary tales' that the processes of justice were subverted and overturned. Savage sees the desire to "preserve the public decorum crucial for the maintenance of hierarchies of class, gender, and age' as the impetus for the 1926 Act, rather than reflecting concerns with individuals' rights to privacy. ${ }^{67}$ Economic factors were also involved, with reports of divorce cases being 'central to the intense competition among the cheap mass media papers'. ${ }^{68}$ Humphreys also argues that newspaper reporting of divorce, cases in Britain 'naturalized' the idea of divorce rather than acting as a deterrent. ${ }^{69}$ Even though the actual number of divorces was low in

\footnotetext{
${ }^{64}$ Barbara Leckie. Culture and Adultery. The Novel, the Newspaper and the Law, 1857-1914. Philadelphia: $1999,62$.

${ }^{65}$ Anne Humphreys. 'Coming Apart: The British Newspaper Press and the Divorce Court', in NineteenthCentury Media and the Construction of Identities, eds. Laurel Brake et al. Houndmills: 2000, 220.

${ }^{66}$ Gail Savage. 'Erotic Stories and Public Decency: Newspaper Reporting of Divorce Proceedings in England'. The Historical Journal 41, no.2 (1998): 527.

${ }^{67}$ Ibid., 527-28.

${ }^{68}$ Humphreys, 226.

${ }^{69}$ Ibid., 228.
} 
England in the nineteenth and early twentieth century, the frequent reporting of divorce cases by newspapers gave the impression that divorce was common.

Agreeing with the British arguments, Peter Fraser, a Labour MP and Scotsman, made two unsuccessful attempts to pass the Judicial Proceedings (Regulation of Reports) Bill in 1928 and $1931 .^{70}$ In 1934 John Cobbe, a United (government) MP, introduced a bill of the same title which also failed. ${ }^{71}$ The New Zealand Law Journal supported these attempts, claiming in 1928, 'there is no question but that fear of publicity prevented the bringing of proceedings in a great number of cases where misconduct was alleged and admitted....It is the innocent party who as a general rule dreads publicity, not the guilty party...After all publicity is only one of the punishments for misdemeanour, whether domestic or public'. ${ }^{72}$ In contrast, Truth described Peter Fraser's speech introducing the 1928 bill as a 'hysterical monologue by (St.) Peter' and claimed that the bill was 'calculated to injure the delicate fibre of public morality'. ${ }^{73}$ Clearly, the dominant opinion, at least in Parliament, lay on the side of public scrutiny since the press remained free of such restrictions for another thirty years.

Finally, in 1958, Attorney-General Rex Mason introduced the Divorce and Matrimonial Causes Amendment Act that passed with the support of the Labour government. ${ }^{74}$ Mason justified the need for such a law by saying:

Honourable members, perhaps not so much in recent years as in earlier years, may have seen reports of divorce cases where the unhappiness of the parties and other circumstances relating to cases of adultery have been featured in a way not exactly conducive to standard morality, and sometimes in a way that has given great pain to the children of the parties in the divorce proceedings. I do not want to enlarge upon that, but I can think of cases where the result has been most unfortunate. ${ }^{75}$

\footnotetext{
${ }^{70}$ Journals of the House of Representatives, Session 1928, vol. I. Wellington: 1928, XXXV; Journals of the House of Representatives, Session II, 1931. Wellington: 1931, XXXII. The 1931 bill passed three readings in the House of Representatives but lapsed in the Legislative Council. Bassett and King suggest that as Fraser was married to a divorced woman he would have been more aware than most of 'the hurt such reports could cause innocent parties'. Michael Bassett with Michael King. Tomorrow Comes the Song. A Life of Peter Fraser. Auckland: 2000, 114. There is no evidence of the Kemp divorce having been covered in the newspapers, but even the possibility of such reporting could cause much anxiety.

${ }^{71}$ Journals of the House of Representatives, Session 1934-35. Wellington: 1935, XLIX.

72 'Report of Judicial Proceedings and Divorce (Consolidation) Bills'. NZLJ, 18 September 1928, 215. See also 'Reports of Judicial Proceedings'. NZLJ 18 August 1931, 189; 'In the Interests of Decency'. NZLJ, 24 July 1934, 173.

73 'How Wicked! Hysterical Monologue By (St.) Peter'. NZT, 6 September 1928.

${ }^{74}$ Divorce and Matrimonial Causes Amendment Act 1958 (1958 No 30).

${ }^{75}$ NZPD, 318, 9 September 1958, 1624-1625.
} 
Other Labour MPs argued that innocent people hesitated to divorce their guilty spouse because of their fear of being named by the newspapers. ${ }^{76}$ The National Party argued the potential to be named and shamed by the newspapers served as a useful instrument of social control by producing shame through their stories. Both sides agreed the potential to be named in a divorce case story deterred petitioning for divorce. Thomas Murray, a National MP, claimed, 'people do not like to wash their dirty linen in public, and the very fear of such a thing happening may save many marriages from going on the rocks' ${ }^{77}$ In contrast, James Deas, a Labour MP, argued:

To my mind the only morals to be protected, or considered, in divorce proceedings are those of the parties concerned and they are not protected in any way by publication of facts which bring reflections on the children of the marriage, if there are any, and harm, hurt, and distress to the parents and relatives on both sides. ${ }^{78}$

National MPs supported the practice of shaming divorcing couples in public to prevent other New Zealanders from divorcing, whereas Labour MPs sought to protect the privacy of the divorcing couple and their family.

The Divorce and Matrimonial Causes Amendment Act limited the details that could be published about a divorce suit to, 'the names, addresses, and occupations of the parties and witnesses; the ground of the petition, and a concise statement of the charges, defences, and counter-charges in support of which evidence has been given; submissions on any point of law arising in the course of the proceedings, and the decision of the Court on the submissions; and the summing up of the Judge and the finding of any jury, the decision of the Court, and any observations made in giving it' ${ }^{79}$ It also allowed judges to prohibit any reference to cases before the court. This provision outraged Jack Marshall, a National MP, who claimed:

this amendment would give the Court power to prohibit even any reference to the fact that the proceedings had been before the Court, which means that a case could be heard in secret. That cannot be justified on the grounds of

\footnotetext{
${ }^{76}$ One of the catalysts for this particular Bill was the coverage by the press of the Prevost divorce in Auckland in 1953. The Auckland Star and the New Zealand Herald covered the case extensively, as well as the Evening Post in Wellington. The Prevosts were a wealthy couple, and Charles Prevost had petitioned for divorce on the ground of his wife's adultery. On some days there were over 100 members of the public in court listening to the evidence. For examples of the press coverage see, "Action Before Jury. Hearing Continued in Divorce Case'. EP, 24 March 1953; 'Threat to "Break" Any Friends Sheltering Wife Denied'. Auckland Star, 25 March 1953; 'Caretaker Tells of Beach Parties. Evidence in Third Day's Hearing of Divorce Action’. New Zealand Herald, 26 March 1953. For further details see Yska, 126-27.

${ }^{77}$ NZPD, 318, 9 September 1958, 1632.

${ }^{78}$ Ibid., 1626-27.

79 ‘Amending Bills before the House. Divorce Reports to be Limited?' EP, 1 August 1958.
} 
public morality, which is the justification for the existing provisions of the law. Publication of the fact that a divorce case has come before the Court, with the names of the parties, cannot by any stretch of the imagination be prohibited on the grounds of public morality. We consider it wrong in principle that the House should give to the Courts power to decide that a case shall be heard in secret. ${ }^{80}$

Publications of a 'technical nature' such as law reports, medical journals and studies relating to psychology, marriage guidance or social welfare work were exempt. ${ }^{81}$ The 1958 law did not allow for the publication of the name of the judge or for the names of the lawyers representing the various parties. This upset some members of the legal profession, as Jim Kent, a Labour MP explained, 'I suppose solicitors are entitled to any advertising they can get because their particular union prohibits them from advertising, ${ }^{82}$ While the practice of law was not highly specialised in New Zealand during the first half of the twentieth century, there were a small number of lawyers in each of the main centres who dealt with the majority of divorce cases. ${ }^{83}$ Having their names published in newspaper reports was one way of attracting future clients.

A disagreement over whether marriages were private relationships or relationships in which the public had a stake and a right to monitor was at the centre of the debate around the right of newspapers to publish details of divorce cases. James Deas believed that the bill was an attempt to protect privacy. He said, 'Why should the proceedings be blazoned in print for the consumption of people with salacious tastes?...Divorce proceedings and the private affairs of people should be at the head of any list of matters which newspapers

\footnotetext{
${ }^{80}$ NZPD, 318, 9 September 1958, 1625.

81 'Amending Bills before the House. Divorce Reports to be Limited?' EP, 1 August 1958.

${ }^{82}$ NZPD, 318, 9 September 1958, 1628.

${ }^{83}$ Lawyers were instructed a total of 2,576 times in the 2,195 files examined. The composition of law firms was often changing, so it is difficult to be precise about which firms appeared the most in divorce cases. In saying this, the most frequent firm to appear was Wilford, Levi \& Jackson or Levi, Jackson \& Yaldwyn which appeared in 291 cases (11.30\%). (Thomas Wilford, mentioned in Chapter One, was a partner and a practising solicitor at the same time he was advocating divorce law reform in the House of Representatives, see Wade Mansell. 'The History of the Development of the Grounds for Divorce in New Zealand'. LLM thesis, Victoria University of Wellington, 1970,92). The next two most frequent appearances were made by Mazengarb, Hay \& MacAlister (136 times, 5.28\%) and A.B. Sievwright (115 times, 4.46\%). Histories of law firms and legal societies tend not to mention divorce, so it is difficult to know to what degree their core business relied on such work. For example there is no mention of divorce litigation in the following works: Robin Cooke, ed. Portrait of a Profession. The Centennial Book of the New Zealand Law Society. Wellington: 1969; M.J. Cullen. Lawfully Occupied. Otago District Law Society. Dunedin: 1979; Julia Millen. The Story of Bell Gully Buddle Weir 1840-1990. Wellington: 1990; Peter Spiller. The Chapman Legal Family. Wellington: 1992; R.C.J. Stone. The Making of Russell McVeagh. The First 125 Years of the Practice of Russell McVeagh McKenzie Bartleet \& Co. 1863-1988. Auckland: 1991.
} 
have no justification for publishing, ${ }^{84}$ In contrast, the conservative National MP Ronald Algie argued:

Marriage is not merely a private matter. It creates what lawyers call a status, and that causes the law of divorce to be treated rather differently from the law of contract. Marriage is far more than a contract. It arises from a contract but it receives from the fulfilment of church and State requirements something more than that....It is the law under which we live. Our law of marriage has been profoundly influenced by the church and I hope that will continue to be so. It would be a terrible thing if the law of marriage came to be regarded only as a contract. This has happened. There have been times in the Roman State when marriage was a very high form of religious and social agreement. At that stage the Roman community was at its best. When, after the fall of the Republic, marriage came to be regarded as no more than a private contract, the Roman community at that time was at its lowest ebb. Some communities in the modern age have treated marriage as a mere contract, and they have not been communities we would admire. ${ }^{85}$

The continual debates, both in parliament and in society more generally, about the nature of marriage (and consequently the dissolution of such relationships) demonstrated that some New Zealanders considered the dissolution of marriages and familial relationships inappropriate subjects for newspaper stories, while others considered the monitoring and the threat of exposure necessary in order to maintain marital stability.

There was also some discussion in Parliament on the quality of the press in New Zealand and how it differed to the press in the United Kingdom. In introducing the bill, Rex Mason claimed, '[i]n general I say frankly that our newspapers observe a pretty high standard in these matters. One cannot say that that is so without exception, and if the standard is relaxed in any way it might well be that a competition for creating sensation might be started' ${ }^{86}$ Jack Marshall claimed, '[w]e have a press of a much higher standard than that of the popular press in the United Kingdom', and therefore New Zealand did not require the same form of press restriction which existed in the United Kingdom. ${ }^{87}$ Certainly New Zealand did not have the range of tabloid newspapers that existed in Britain, but it was not only tabloids that reported on divorce cases. Truth was only mentioned in the debate in parliament as a result of a misunderstanding between Jim Edwards (Labour) and Sidney Smith (National).

\footnotetext{
${ }^{84}$ NZPD, 318, 9 September 1958, 1626-1627.

${ }^{85}$ Ibid., 1627.

${ }^{86}$ Ibid., 1625.

${ }^{87}$ Ibid
} 
Mr Edwards - It is true that there are newspapers that quickly take advantage of the misfortunes of people to print stories that will sell their newspapers. Unfortunately, we have such newspapers in New Zealand. They publish whatever scandals they can get from the law Courts and it would be true to say that where such papers get into the homes they may have a bad influence on the children. Before anyone considers whether the truth should be printed -

Hon. S. W. Smith - That has a very low standard.

Mr Edwards - I am not referring to any newspaper. My point is that it would be better for all concerned if we prevented newspapers making a profit out of the publication of people's misfortunes. ${ }^{88}$

While reluctant to name Truth, it seems clear from the debate that it was the newspaper that most MPs had in mind when discussing the issue of how divorce cases were reported.

Other National MPs, along with the press, who opposed the legislation, believed publicity was necessary 'so that if either collusion or connivance exists and is known to a member of the public, that person may at least know that a petition is before the Court and the grounds of the petition, and may have the opportunity of communicating the facts to the authorities'. ${ }^{89}$ The Evening Post argued:

It cannot be too strongly emphasised that any legislation that places restrictions on the rights of the Press to report proceedings before the Courts is also a restriction on the rights of the public... The terms of the Bill remove substantially the deterrent of publicity from those intending to break the moral law. It is not the fear of being known as an offender against the moral law that provides the deterrent but the fear that publicity may be given to the circumstances of the offence. ${ }^{90}$

Continuing with the idea that the fear of publicity acted as a deterrent to those considering divorce, the Evening Post argued the following month, '[t]here is reason for concern today about the weakening of the moral structure of society. That being so, it does not seem reasonable to make the way of the transgressor easier by relieving him or her, in part at least, of the fear of publicity'. ${ }^{91}$ There was a strong belief that exposure through newspaper articles was an effective way of maintaining social control and supporting the institution of marriage. One issue not raised in the debate was that sometimes a spouse became aware of their partner's adultery when they were named in another divorce suit. In 1943, for example, a woman told the court she had been made aware her husband had been named as a co-respondent in another divorce case, and this led her to petition for

\footnotetext{
${ }^{88}$ Ibid., 1632.

${ }^{89}$ Cyril Harker, NZPD, 318, 9 September 1958, 1630. Also see 'Bad Divorce Law Should Be Removed'. $E P, 1$ December 1960.

90 'Bad in Principle and Unnecessary in Practice'. EP, 7 August 1958.

91 ‘Third Leader.....' EP, 10 September 1958.
} 
divorce on the ground of adultery. ${ }^{92}$ Despite their claims, the National Party did not change this law when it became government in 1960, indicating some support in its ranks for the right to privacy.

For many petitioners obtaining a divorce was only one of their goals - and for some it was not even the primary goal. The knowledge they gained from surveillance discredited adulterers by informing family, friends and the wider public of their transgression in the hope that this would result in ostracism. Scandal enhanced the power of the 'innocent' party in contentious divorces. ${ }^{93}$ The hearing of the vast majority of cases in open court provided the opportunity to publicise the behaviour of the adulterer. Those who had assisted in the surveillance gave their evidence against the adulterer thus sharing in the public punishment of the guilty party in a verbal version of the biblical punishment of stoning the transgressor. Finally, newspapers provided the final step by 'shaming' the respondent and co-respondent. Surveillance was a mechanism that petitioners, the press, and the prurient but self-righteous public punished and shamed those who had violated their marital vows. Ironically, it served to normalise divorce as the rising numbers of those getting divorced began to lessen the power of scandal, something the majority in the New Zealand Parliament may have come to recognise by 1958 when it voted to end this practice of public humiliation.

${ }^{92} G v G$, AAOM/W3265/D1149/1943/ANZ-W.

${ }^{93}$ For further details see Chapter 7. 


\section{Chapter Six}

\section{Expectations and Disappointments of Marriage: Succeeding and Failing at being Husbands and Wives}

Marriage turned men into husbands and women into wives. While marriage was not the only site in which gender was constructed, it was a central site of gender construction throughout the first half of the twentieth century. As Barbara Brookes has argued, 'notions of work, home, and family were at the heart of the gender order. They gave meaning to lives and marked out those who were successful from those who were not. Marriage, as a public institution, was the place where the state most directly shaped gendered authority'. ${ }^{1}$ In contested cases divorce litigants needed to show their spouse had violated their role as a husband or wife in a fundamental way. While this involved proving their spouse had committed one of the grounds for divorce, it also often involved outlining other failures, and these provide insights into expectations about marriage, gender roles, sexual attitudes, and the lived experience of marital relationships. Complaints made during divorce proceedings reflect notions of gender norms as they pertained to the duties of husbands and wives. A study of complaints made to the court contained in divorce case files reveals people's expectations of marriage and the disillusionment that they felt when these expectations were not met. This chapter offers a qualitative view of what it was to be married, and the disappointments about marriage that motivated the decisions to seek a divorce.

The Supreme Court provided a unique forum for couples to contest what marriage meant to them. This debate was also a way of questioning and confronting gender assumptions. The case records provide evidence of what people were willing to publicly discuss in order to obtain a divorce and what the court would accept as evidence, as well as revealing the interior life of unhappy marriages. Legal requirements involved performing or exhibiting certain kinds of behaviour and intentions to achieve the legal end so the analysis must avoid simply extrapolating the details in a particular case to apply to New Zealand marital behaviours in general. The cases demonstrate a shifting of behaviours of

\footnotetext{
${ }^{1}$ Barbara Brookes. 'Marriage: The Gendered Contract', in Sites of Gender. Women, Men \& Modernity in Southern Dunedin, 1890 - 1939, eds. Barbara Brookes et al. Auckland: 2003, 349.
} 
wives to husbands and husbands to wives, and how such behaviours and expectations were retold in court. The records also show spouses, especially wives, became less prepared to tolerate 'bad' behaviour with more petitions on the grounds of mental cruelty rather than physical cruelty, and increasing numbers of wives citing issues such as their husbands' failure to take them to the cinema or a dance. This growing female assertiveness contributed to challenging the assumed male monopoly, or near monopoly, of marital authority.

Suffrage feminists made strong critiques of marriage and argued against compulsory marriage and motherhood and pointed out that single women often had a more independent and satisfying life. ${ }^{2}$ Jock Phillips has written how '....the New Zealand male, in the thirty years before World War I, may have felt some ambivalence about his marriage. The obvious attractions of a family in the form of security, respectability, and the services of his wife may not have seemed full compensation for the unrestrained and less anxious years of bachelorhood'. ${ }^{3}$ Married couples soon learnt that marriage involved an evolving relationship rather than a static state of being. Many issues challenged marriages. Some couples overcame these issues, but others did not.

Bettina Bradbury has contended that, "journeys back in time do not reveal the "traditional family" that some observers portray as endangered today. The information that scholars have been able to unearth about family life in the past reveals great diversity in the ways families lived, in their structures, in the work their members performed, the roles of men and women, and in cultural meanings attached to the concept of the family'. The point is one widely made by historians of family, marriage and gender against the popular notion that sometime in the past there was a 'golden age' of the 'traditional family'. Certainly, the families whose stories are revealed in the divorce files cannot be said to fit the stereotypical notion of strong 'nuclear' families with breadwinner fathers, housewife mothers and children. What is revealed are far more complex and diverse familial patterns

\footnotetext{
${ }^{2}$ For further discussion of women choosing to remain single see, Katie Holmes. "Spinsters Indispensable": Feminists, Single Women and the Critique of Marriage, 1890-1920'. AHS 29, no.110 (1998): 68-90; Susan Magarey. Passions of the First Wave Feminists. Sydney: 2001.

3 Jock Phillips. 'Mummy's Boys: Pakeha Men and Male Culture in New Zealand', in Women in New Zealand Society, eds. Phillida Bunkle and Beryl Hughes. Auckland: 1980, 227.

${ }^{4}$ Bettina Bradbury. 'Social, Economic, and Cultural Origins of Contemporary Families', in Families. Changing Trends in Canada, $4^{\text {th }}$ ed, ed. Maureen Baker. Toronto: 2001, 69. Stephanie Coontz has also made a similar argument. See The Way We Never Were. American Families and the Nostalgia Trap. New York: 2000 ed.
} 
and particularly variations in the meanings husbands and wives attached to their roles during the first half of the twentieth century in New Zealand. Between the early and midtwentieth century, the emphasis in regard to divorce shifted from complaints about the failure to meet gendered expectations to issues of emotional incompatibility. This echoes a broader shift from marriage as an economic, and sharply gendered partnership in relationship to labour, to an intimate relationship that ideally should have satisfied both spouses. ${ }^{5}$

The significance of the language of love and relationships as well as the importance attached to being married, are clear from a reading of the cases. The language, significance and emphasis placed on romance and attachment applied to marital relationships as well as adulterous relationships. It is also important to consider societal norms and functions which marriage performed (and performs). Marriage operated as a reproductive relationship, an economic relationship, the basis for household organisation, family relationships and identities, as the main form of parenting, and an organiser of adult lives as the basis for social interaction. ${ }^{6}$ People entering marriages had certain expectations about how they should behave, and about how their spouse should behave in relation to these multifarious functions of marriage.

There were a number of major causes of disputes between married couples that were not grounds for divorce, but were presented to the court as evidence of a failure of one or both spouses to fulfil expected gender norms. Money was often a contentious issue, with disputes over who should earn the money and how it should be spent. Socialising caused many disagreements. Wives frequently argued that their husbands did not take them out often enough. Many husbands complained that their wives failing to perform their household duties to an adequate standard. These complaints most often focused on the failure to prepare meals. Other spouses felt their husband or wife did not understand the responsibilities marriage entailed. The grounds of drunkenness, cruelty, failure to maintain, and failure to perform domestic duties as well as the ground of insanity are also

\footnotetext{
${ }^{5}$ For a work that emphasises the importance of companionate marriage in the post-World War II period see, Janet Finch and Penny Summerfield. 'Social Reconstruction and the Emergence of Companionate Marriage, 1945-59', in Marriage, Domestic Life and Social Change. Writings for Jacqueline Burgoyne (1944-88), ed. David Clark. London: 1991, 7-32.

${ }^{6}$ For a study of marriage in nineteenth-century New Zealand see, Frances Porter, Charlotte Macdonald with Tui McDonald, eds. 'My Hand Will Write What My Heart Dictates'. The Unsettled Lives of Women in Nineteenth-Century New Zealand as Revealed to Sisters, Family and Friends. Auckland: 1996, 185-311.
} 
explored in this chapter. Of all the grounds for divorce these were the most differentiated by the gender of the petitioner. Moreover, the ground of drunkenness coupled with either cruelty, or failure to maintain, in the case of husbands, or drunkenness coupled with failure to perform domestic duties, in the case of wives, enshrined in legislation the gendered expectations of husbands and wives.

Considering a spousal homicide case, Brookes asserted court records 'suggest that all marriages were open to public view and community assessment in ways that made them central to understandings of gender in society'. ${ }^{7}$ Clearly a homicide was a more serious end to a marriage than divorce, but it could be argued that divorce would have been a better outcome than this dire act. While the main witnesses in divorce cases were the two spouses, often their extended family members, neighbours or friends gave evidence about the nature of the couple's marriage. Gail Savage has identified a gender divide in British matrimonial cases, with women giving evidence on behalf of the wife, and men giving evidence on behalf of the husband, with the exception of police officers who gave evidence on behalf of wives. ${ }^{8}$ In the Wellington sample, familial relationships played a larger role than gender. Parents gave evidence on behalf of their children, and children sometimes gave evidence on behalf of their parents. Normally children gave evidence in support of their mother's claim of desertion, but in certain cases they also gave evidence in support of their father's petition for divorce. The 'children' giving evidence in court were normally at least fourteen years old, and were sometimes adults. Gender played a more important role in relation to friends and neighbours. The friends and neighbours giving evidence supporting wives' claims tended to be women, and in the case of husbands, men.

New Zealand patterns of homosocial leisure and heterosexual marital expectations could become a source of irritation indicating the potential for conflict between gender expectations in marriage and outside the home. ${ }^{9}$ In April 1926 Frederick R. married Ruva

\footnotetext{
${ }^{7}$ Brookes. 'Marriage: The Gendered Contract', 354.

${ }^{8}$ Gail Savage. “"A State of Personal Danger”: Domestic Violence in England, 1903-1922', in Violence and Civilisation in Historical Context, ed. Katherine D. Watson. Newcastle: 2007, 276.

${ }^{9}$ For a discussion of homosocial networks see, Carroll Smith-Rosenberg. 'The Female World of Love and Ritual: Relations between Women in Nineteenth-Century America'. Signs 1, no.1 (1975): 1-29. For New Zealand see, Charlotte Macdonald. 'Ways of Belonging: Sporting Spaces in New Zealand History', in The New Oxford History of New Zealand, ed. Giselle Byrnes. Melbourne: 2009, 269-96; Barbara Brookes, Annabel Cooper and Robin Law, eds. Sites of Gender. Women, Men \& Modernity in Southern Dunedin, 1890-1939. Auckland: 2003.
} 
B. at St. Augustine's Anglican Church in Petone. The couple had three sons born between 1927 and 1933. Frederick petitioned for a divorce in April 1940 on the ground of separation of three years or more. He did not pursue his petition, but notes were taken for a counsel's opinion. In these notes Frederick explained:

owing to the interference of my wife's mother and the violent temper of my wife unhappy differences arose between my said wife and myself. About June 1929 a man named Robert H[...] began to exercise a strong influence over the behaviour of my said wife who confessed to me that she was in love with him. This strained our marital relations and led to many bitter quarrels... a few months after the birth of our second child she ordered me out of the house and I left the home... At that stage I was away about three months with my people but I approached my wife and we became reconciled and took a home at Petone early in 1931; we thereupon agreed to observe the following conditions: -

(a) That I should not go out as much as before and should give up several old friends

(b) That my wife should give up all association with $\mathrm{H}[\ldots]$

(c) That we should pull together for the sake of the children

This reconciliation lasted about six months, that is until the middle of 1931, when my wife again began to refer to $H[\ldots]$ as her "Soul Mate". This was intended as retaliation for my complaint that her mother was too much in the house. I had strictly kept up my part of the bargain referred to in the preceding paragraph.

The couple then moved to Silverstream and a third child was born. While there Ruva 'several times told [Frederick] that she did not love [him] and was not going to live with [him]'. Frederick continued his story:

I was able to take her to Sister Mowbray's Rest Home at Waikanae, but it was too late. After a week's stay the Sister asked me to take her home and call a doctor. This was about June 1933. I called in Dr Hutchieson who called an Alienist and they certified her for admission to Porirua Mental Hospital. ${ }^{10}$

Ruva left the hospital in June 1935. Prior to her discharge a doctor informed Frederick that, 'my wife had conceived a violent dislike for me, and he advised me to make a home for myself and the children, and not to see her until she settled down' ${ }^{11}$ Even though there is no evidence of their marriage being dissolved in the case file, it is quite likely that another attempt was made to secure a divorce by either Frederick or Ruva. Regardless, their situation contained many elements common to a significant number of divorce cases from this period. Firstly, in 1940 they had been married for about fourteen years which was only slightly longer than the average length of a marriage prior to divorce at this time. Their attempts at reconciliation prior to petitioning for divorce were also common.

\footnotetext{
${ }^{10} R \cup R$, AAOM/W3265/D5709/1939/ANZ-W.

${ }^{11}$ Ibid.
} 
Socialising was a frequent source of conflict, with some spouses complaining of the frequency that their husband or wife socialised or about the people with whom they socialised, as in this case. In other situations wives complained their husbands did not take them out enough and that they wanted to go to dances or the cinema with their husband more often. Finally, while there were few divorces on the ground of insanity, there were a number more that included some suggestion of mental instability, as in the above example, without using insanity as the legal ground for ending the marriage.

Spouses might have ideas about romance or excitement not met by their partners, while others seemed willing to make the best of a situation, even if it were less than ideal. Some divorce petitioners expressed their 'tiredness' with the monotony of marriage. Forty-four year old Mary O. told the court in 1906, when she was petitioning for divorce on the grounds of adultery and cruelty, that 'I am tired of my matrimonial life and want to get rid of it and him'. ${ }^{12}$ In 1928 Muriel C. told the court 'I think my husband was tired of married life and wanted to be a free agent. He told me that. He left me that day'. ${ }^{13}$ In 1939 Alexander J. petitioned for divorce on the ground of his wife's failure to comply with a restitution for conjugal rights. During the first half of the twentieth century, the age at first marriage decreased, while life expectancy increased resulting in far longer marriages than earlier generations. ${ }^{14}$ While some might have perceived the certainty and security of marriage as an advantage, others found it restrictive and boringly predictable. The growing emphasis on intimacy, sexual attraction, and emotional satisfaction over the twentieth century only increased the significance of these differing expectations as a justification for separation or divorce. ${ }^{15}$

When discussing husbands' and wives' expectations of one another it is important to distinguish between idealised behaviour and expected standards of behaviour. There were similar expectations among most couples, and a general agreement on a minimum standard of acceptable behaviour, although expectations varied from person to person. Given that marriage was a central institution in the construction of gender, understanding the ways in which gender was constituted within a marriage as well within other

\footnotetext{
${ }^{12} O v O$, AAOM/W3265/D674/1905/ANZ-W.

${ }^{13} C v C$, AAOM/W3265/D3187/1928/ANZ-W.

${ }^{14}$ Ian Pool, Arunachalam Dharmalingam and Janet Sceats. The New Zealand Family from 1840. A Demographic History. Auckland: 2007.

${ }^{15}$ Christina Simmons. Making Marriage Modern. Women's Sexuality from the Progressive Era to World War II. New York: 2009.
} 
institutions, especially the ensemble of state institutions and charitable aid organisations, makes clearer what it was to be a man or a woman in the first half of the twentieth century in New Zealand, and how these understandings and meanings changed during this period as well. Brookes, Cooper and Law have argued '[n]ormative styles of masculinity and femininity were reshaped over this period [1890-1939] in which women asserted their right to citizenship'. ${ }^{16}$ Given the many connections between women's standing as wives and as citizens it is not surprising that as wives gained more legal recognition, meanings of masculinity and femininity changed, although there were many continuities as well.

Family historians emphasize the importance of the growth of companionate marriages in the history of the family during the nineteenth and twentieth centuries. This is seen as the triumph of love over marriage for economic or other reasons. At the same time, there is a difference between companionate relationships and romantic, passionate love. Some individuals wanted to maintain romantic, passionate relationships but found this difficult over the course of a long relationship. The demise of this passionate love prompted some individuals to leave their marriages. Others tried to rekindle former feelings of affection, but found this impossible. One husband wrote to his estranged wife in 1932 after she had asked for a reconciliation, 'it is quite impossible to revive any of the affections I formerly had for you, and without this you will understand a reunion, if possible at all, would terminate with disaster with a life of perpetual misery for us both. Perhaps you yourself are mistaken in thinking that you still have a lingering affection for me and that this is merely a longing to see the boys again'. ${ }^{17}$ In 1939 Amanda Y. wrote to her husband of nine years to explain her leaving. She wrote, 'we did not make a success of the years we did have together so let us see what we can do apart. I am sorry to have to tell you I no longer care for you, so what would be the use of coming back to the same unsatisfactory state of affairs. Please do not ask me to come back to you again as I have definitely decided not to do so'. ${ }^{18}$ The growing emphasis on sexual compatibility in this period, increased further in the post-World War II years. Nancy Cott has argued that marriage was seen 'as more companionate, more flexibly defined, less hierarchically structured',

\footnotetext{
${ }^{16}$ Barbara Brookes et al. 'Situating Gender', in Sites of Gender. Women, Men \& Modernity in Southern Dunedin, 1890-1939, eds. Barbara Brookes et al.. Auckland: 2003, 2.

${ }^{17} L v L$, AAOM/W3265/D4076/1932/ANZ-W.

${ }^{18} Y \vee Y$, AAOM/W3265/D5597/1939/ANZ-W.
} 
and 'sexual fulfilment was an acknowledged reason to marry, even apart from having children'. ${ }^{19}$

When a husband or wife explained their adulterous relationship to their spouse they often emphasised the 'true' feelings of love they had for their new partner in contrast to their feelings for their spouse. This pattern was in part accentuated by the fact that it was those involved in long-term extramarital affairs as adulterers who were most likely to confess to their relationships and explain (and justify) their liaison. They also hoped for a divorce. People involved in adulterous relationships often referred to their new partner as their husband or wife. In part this was a cover if they were living together, but also represented their feelings of affection and a desire to validate their relationship and to fit in with acceptable forms. In 1916 when Lucy P. petitioned for divorce on the ground of her husband's adultery she presented to the court a letter which he had written to her explaining he had formed a relationship with another woman. He wrote:

I thought that when you came out here [from England] it would right things and we should be happy once again but that I find is impossible for the girl whom I look up to as my wife and the only one I can be happy with is more than anything else to me on this earth. Like all things it started with friendship but ours ripened into love. I have never hid anything from her and she knows the circumstances in which I am placed but like a true woman is willing to wait for me so you see it is useless expecting me to return to you and I hope that you will think it all for the best and look on the bright side of things and forget that such an ungrateful creature as I ever lived. We have one consolation in knowing that love can conquer anything and that others have done the same thing. ${ }^{20}$

Lucy, however, was left with an 11 year old son and 9 year old daughter. Of course, by divorcing her husband she also made it possible for him to marry his new partner. In 1942 Alfred R. wrote to his wife Joyce, 'By now you will have learnt that I went to Australia to join Joyce $\mathrm{H}[\ldots]$ with whom I have been in love for a long time. I am sorry that our marriage has crashed and I fully honour that it is my fault and not yours. However it is no good blaming anyone and the fact of the matter is we are in love and hope to marry one day'. ${ }^{21}$ The importance of sanctifying their love relationships with a marriage is evidence of the continuing importance of marriage in a time of increasing divorce, and people's continual belief in the institution of marriage even as they entered and exited it at increasing rates. Paradoxically divorce may have served as an indication of the growing

\footnotetext{
${ }^{19}$ Nancy Cott. Public Vows. A History of Marriage and the Nation. Cambridge, Mass.: 2000, 181.

${ }^{20} P \vee P$, AAOM/W3265/D1411/1916/ANZ-W.

${ }^{21} R v R$, AAOM/W3265/D601/1942/ANZ-W.
} 
emphasis on marriage as the major source of emotional satisfaction and sexual pleasure for women as well as men.

Marriage was a financial contract, but it was not an equal agreement, giving husbands more power than wives. Men's responsibility of providing an income for the family raised questions about their masculinity when they failed to support their families - even in the midst of the Depression of the 1930s. Money became a source of conflict for many couples. ${ }^{22}$ Husbands were expected to earn enough money to support their wife and children. Wives could petition for divorce if their husbands failed to support them over a period of time. A financially cautious husband claimed in 1919 that: 'There was always one thing that I used to fear, and that was that something would happen, and that you would have to go out and work to keep me and that was why I always wanted to be careful, not that I was mean, as your people accuse me of ${ }^{23}$ Money was the source of many other conflicts, with wives complaining their husbands did not allocate them enough money to run the household, and husbands claiming their wives were spendthrifts or demanding to know exactly how the household money was being spent. In 1945 , Raymond C. told the court 'I was no more cautious about money than any other man, I like to know what happens to it. It's news to me that I asked my wife to keep a record in a book of expenses'. His wife Patricia claimed that, 'my husband asked me if I would mark down everything I spent. He showed me a book where he'd marked down every item he'd spent, every item, tram fare and ice-cream. I said I'm not used to that, everything just comes and goes. I'm not wasteful but I couldn't be as thrifty as that' ${ }^{24}$ Couples entered marriage with expectations about how money should be divided and spent, in part based on their own experiences and how their parents managed money. When there was a difference of opinion, husbands generally had the upper hand, as they were more likely to be in paid employment. Wives contributed greatly to the finances of the household by managing the money as thriftily as possible, expecting to be trusted in this role rather than

\footnotetext{
${ }^{22}$ For a study which focuses on the relationship between financial tensions and violence in Liverpool see, Pat Ayers and Jan Lambertz. 'Marriage Relations, Money, and Domestic Violence in Working-Class Liverpool, 1919-1939', in Labour and Love: Women's Experience of Home and Family, 1850-1940, ed. Jane Lewis. New York: 1986, 194-219.

${ }^{23} O \quad v \quad O$, AAOM/W3265/D1787/1919/ANZ-W. For other husbands who tried to limit household expenditure excessively or were unhappy about the idea of their wife taking paid employment see, $T \vee T$, AAOM/W3265/D3240/1928/ANZ-W; $B v B$, AAOM/W3265/D405/1941/ANZ-W.

${ }^{24} C v C$, AAOM/W3265/D1881/1945/ANZ-W. Other husbands also considered their wives' spending to be extravagant. See $P$ v $P \& B$, AAOM/W3265/D1971/1920/ANZ-W.
} 
having to report all expenditure to their husbands as Raymond C. wanted Patricia to do. Quarrels over these issues could ultimately end up in court.

Many wives complained about their husbands' reckless attitude towards money and their failure to provide for their wife and children. In 1920, Annie M. petitioned for divorce on the ground of her husband's adultery with Agnes M. The couple had four children aged between 10 and 18. Annie wrote to Charles:

Within the last eight years you have squandered thousands of pounds gadding about the country in the company of harlots who like yourself gave not one moment's thought as to how those in your home were doing. Do you imagine for one moment that you have given your family the consideration a man in your circumstances could and should have done. You have neither given them a trade or a decent education; no, you have lavished your money on harlots to satisfy your lustful desire. ${ }^{25}$

She claimed early in their married life she had scrimped and saved to help him and that once he had become financially stable he had gone and spent the money on other women. In the same year Joyce H. also claimed her husband had led an extravagant lifestyle but neglected to provide her with the basic necessities by failing to pay bills for clothing, 'causing the Petitioner embarrassment and annoyance'. ${ }^{26}$ Some wives, however, took full control of the household spending with husbands handing over their entire pay packet. In 1947, John Q. told the court that his wife had deserted him seven years earlier and after she left he found out that she was $£ 200$ in debt. He said, 'I gave her my wages. She used to tell me that everything was paid up'. ${ }^{27}$ When couples views about the allocation of the household income differed greatly, these disagreements created tensions. This was particularly the case when there was a major disparity between the amount of money that one spouse spent compared with the other.

Socialising could also cause conflict. Wives most often complained their husbands did not take them out often enough. Some husbands were equally unhappy when their wives decided to go out without them. It is clear that most spouses believed it was the husband's responsibility to organise social outings. This may reflect that husbands controlled funds for such outings, as well as transport and the means to release wives from the responsibility of child care. In 1904 Wilhelmina A. left her husband Benjamin and their

\footnotetext{
${ }^{25} M v M$, AAOM/W3265/D1927/1920/ANZ-W

${ }^{26} H v H$, AAOM/W3265/D1955/1920/ANZ-W.

${ }^{27} Q v Q$, AAOM/W3265/D177/1947/ANZ-W.
} 
three children to go and live at the establishment of Mrs Foley in Cuba Street, where she had regularly been attending dances. Wilhelmina defended her actions to the court. When she was asked under cross-examination, 'You told your husband that it was by the doctor's orders you went to those dances? - They told me to go out as much as I could and enjoy myself' ${ }^{28}$ Another wife who equally enjoyed attending dances complained in 1943 about how her husband did not instigate any outings for the couple and so she went to the pictures and to dances without him. She told the court, 'It was not my place to ask him out it was his place to ask me out. There was only one occasion he asked me out when I had too much work to do'. ${ }^{29}$

Other wives left their husbands because of the loneliness and isolation they felt. For example, in 1929, Kathleen L. wrote to her husband, 'You left me alone at week ends \& at nights - You never tried to take any interest in what amused me \& God knows I'm not an old woman - although this life is getting me right down' ${ }^{30}$ In another letter she wrote, 'I've studied others so long. I'm out for a little happiness myself now' ${ }^{31}$ Husbands also complained about social behaviour, but their issues were not about a lack of socialisation, but their wives socialising too much, or socialising with people they considered to be inappropriate friends. For example, a Feilding husband complained about his wife's female friends. In 1920 he told the court, 'I did not like her going to Wellington because I did not like the girl. She was not a suitable companion for any woman'. ${ }^{32} \mathrm{He}$ added, 'It is an absolute lie that I have refused to go out with my wife. Since the baby was born I have had to stay home to look after it'. ${ }^{33}$ It is not surprising couples had different views on the suitable amount of socialising that should take place outside the home. What is more telling is that all of the disputes focus on the nature of the wife's socialising - either the husband's failure to take her to the cinema or dances more frequently or her assertiveness in attending such events by herself or with female friends. This is indicative of the fact that husbands and wives felt that wives should not go out alone, especially at night and that husbands had the right to decide on the nature of their wives' social activities and with whom they socialised. Wives were far less likely to be in paid employment and so

\footnotetext{
28 'A City Divorce Case'. EP, 13 February 1906.

${ }^{29} S v S \& M$, AAOM/W3265/D1209/1943/ANZ-W.

${ }^{30} L v L$, AAOM/W3265/D4076/1932/ANZ-W.

${ }^{31} L v L$, AAOM/W3265/D4076/1932/ANZ-W.

${ }^{32} P$ v $P$ \& B, AAOM/W3265/D1971/1920/ANZ-W.

${ }^{33} P$ v $P$ \& B, AAOM/W3265/D1971/1920/ANZ-W.
} 
spent much more time in the home during the day, which made them more keen to go out in the evenings.

The issue husbands most frequently complained about was their wife's failure to perform household duties to an acceptable standard. While this complaint, coupled with habitual drunkenness, was an official ground for divorce, most husbands more often used another ground - adultery or separation for example - but gave evidence of their wives' 'failure' to perform their duties. In 1906 Jeremiah S. complained, 'Mrs S[...] almost invariably refused to cook my food \& when I was preparing my own food she would come $\&$ abuse me $\&$ on one occasion I said if you do not go away I will put you out of the room $\&$ then she would perhaps spit in my face'. ${ }^{34}$ Likewise, in 1931 Alfred G. complained:

At its worst period, my home life was - as soon as one put one's foot inside the door there was someone growling, and frequently the meals were only half prepared. Frequently the children had their meals before I got home. I was late sometimes but I made an effort to get home. Breakfast I got myself.... They did not have it ready for me the night before. Towards the end...I had to buy my own food. I would have to do my own cooking. Towards the latter part I would have to bring the food in myself. ${ }^{35}$

Obviously the expectation that a wife was the cook and meal preparer could lead to conflicts when she failed to complete these duties to the satisfaction of her husband.

While food preparation was a major concern of many husbands, their complaints regarding the household were not limited to meals. In 1948 James B. told the court 'At the time of marriage my wife was 4 months pregnant, and she is about 8 years older than I am. The marriage was not a happy one - very little happiness. The cause was the home was neglected, food not properly prepared, no attraction for a home life. As a result of this wife and I had quarrels'. ${ }^{36}$ In 1922 Arthur T. had his lawyer write to his wife, Florence as part of his petition for a restitution of conjugal rights. The lawyer wrote to Florence,

Your attitude towards him is quite contrary to your duty as a wife...Although you are paid $£ 3$ per week you have neglected his room, his general comfort and his meals. You supply him with no food and he is compelled to do for himself... You are behaving in such a manner in his house that you are not his wife, a friend nor a housekeeper... If you are determined to continue to fail in

\footnotetext{
${ }^{34} S v S \& R$, AAOM/W3265/D722/1906/ANZ-W.

${ }^{35} G v G$, AAOM/W3265/D3789/1931/ANZ-W.

${ }^{36} B \cup B$, AAOM/W3265/D2621/1946/ANZ-W.
} 
your duty to your husband as his wife then you had better consider what is to be the outcome. Your husband will not tolerate your impossible attitude. ${ }^{37}$

Husbands revealed these assumptions when they tried to convince their wives to return, explaining their complete failure to perform duties previously carried out by their wife. For example, John wrote to his wife stating, 'It is an awful life for me now as I have to cook my own meals the best I can and I am not getting even one decent meal a day'. ${ }^{38}$ The most direct acknowledgement from a husband of the importance of the work wives carried out came from Stan in 1929. He wrote to his estranged wife, 'for although I know I can never love anyone the same again I may be forced to find someone for the boys' sake for I can see quite plainly that where there is no woman in the home there is no real cleanliness, and home comforts'. ${ }^{39}$ Clearly husbands expected their wives to run the house and provide daily meals - essentially they were expected to perform all the roles of a housekeeper, as Arthur T'.s lawyer argued. The problems that arose when wives did not perform these tasks, for whatever reason, points to the importance for men of having someone to do these time-consuming duties, and the major problems they faced when their wives refused to do so. Running a household was a full-time job, and most husbands who were in paid employment had neither the time nor the skill to complete these jobs when their wives failed to do so. These cases also provide evidence that not everyone sought only love and companionship from marriage; some saw it more as a way to exchange financial security for an unpaid housekeeper and child minder.

Another common complaint found in the divorce case files concerned the interference of the wife's mother. In 1916 John L'.s lawyer wrote to his wife to say, 'Your mother is the cause of friction between you and him, then you have to remember that when you choose your husband he is entitled to your first consideration and everybody else comes second. I have had many instances in which the mother-in-law has succeeded in parting a daughter from a husband and I am loath to believe that your mother would do such a thing' ${ }^{40}$ Despite the view advocated by this lawyer that wives should put their husbands before their mothers, many women showed greater attachment to their mothers, and trusted them more to act in their best interests than their husbands.

\footnotetext{
${ }^{37} T v T$, AAOM/W3265/D2355/1922/ANZ-W.

${ }^{38} T v T$, AAOM/W3265/D3240/1928/ANZ-W.

${ }^{39} L v L$, AAOM/W3265/D4076/1932/ANZ-W.

${ }^{40} L v L$, AAOM/W3265/D2395/1923/ANZ-W.
} 
Wives could also face problems dealing with in-laws when newly-married couples had to live with one set of parents. This was particularly a problem during the Depression and after World War II when there was a housing shortage. Edith T. told the court in 1945: 'In September 1934 we were living with his people and my husband was working for his father. I did not get on well with his people and then my husband lost all his money'. ${ }^{41}$ The couple separated in October 1935. It was very hard to have two sets of couples under one roof, and particularly so for wives who spent a lot of time at home, under the surveillance of their mother or mother-in-law. There was a general expectation a newlymarried couple would set up their own home, and most couples delayed marriage until they could afford to do so. To have to live with one's parents or in-laws was undesirable and made the full transition to adulthood impossible, which for many was an important reason for marrying.

In other situations, a sibling of one of the couple came to stay in the marital home causing friction. In 1946 Leonard F. told the court, 'My wife left the matrimonial home in 1930. My brother in law came out from England and she could not stand him. As a result of his habits she finally left the house'. ${ }^{42}$ Similarly, in 1940 Bert W. told the court, 'I was residing in Auckland in 1922. Before that no trouble had arisen between us. Trouble arose there by reason of her brother coming to live in the home. In consequence of that relations became strained. I told him to get out. She went with him and I haven't seen her since. That was seventeen years ago and I haven't seen her since'. ${ }^{43}$ Clearly, spouses did not always share the loyalties people felt towards their blood relations leading to situations where a decision had to be made about to whom one owed the greater loyalty. When husbands and wives challenged the marital bond by placing other family members above their spouse, the sense of betrayal might lead to estrangement and divorce.

Differing religious affiliations or degree of religious observance created problems in some marriages. All evidence of religion becoming an issue in marriages, from the Wellington Divorce Database, occurred in the 1940s despite the immediate post-World

\footnotetext{
${ }^{41} T v T$, AAOM/W3265/D2093/1945/ANZ-W.

${ }^{42} F \vee F$, AAOM/W3265/D2333/1945/ANZ-W.

${ }^{43} W v W$, AAOM/W3265/D65/1940/ANZ-W.
} 
War I period being the era when religious sectarianism was most prominent in New Zealand. ${ }^{44}$ In 1943, Florence M. told the court,

I am a Presbyterian. My husband is a Roman Catholic. The religion in which the children were to be brought up was never a source of discussion after marriage. Because of the religious differences between us I suggested we had better part before marriage and we parted. We subsequently resumed courting and discussed the future of any child that might be born. I said I would be the mother and I thought they should go my way. He said that was quite alright. ${ }^{45}$

Later on, this religious difference caused serious disputes and ultimately led to the demise of their marriage. Most disputes, however, were about one spouse being very devoted to some form of Christianity, while the other spouse did not share such a religious fervour. For example, in 1942 Myrtle C. told the court how her husband of 14 years had deserted her in 1938. She explained her husband had told her he was leaving her as 'he said it was better that he should go as he couldn't lead the life that I was leading. He said he couldn't do the things that were right. I belonged to the Salvation Army at the time. He was leading a loose sort of life and I pleaded with him to stop on many occasions' ${ }^{46}$ Similarly, Charles M. said that there was great unhappiness in his marriage after his wife became 'deeply religious'. ${ }^{47}$ In 1944 Isabel B., wrote to her husband to tell him that she would not be returning to him. She wrote, "I again repeat that regardless of your "Christian beliefs" and so forth, NOTHING will change my decision. I don't share your religious beliefs and above all, I don't love you'. ${ }^{48}$ In all these cases one spouse had become more deeply religious after marriage and this difference of outlook proved deeply divisive.

Divorce petitions provide an insight into the violence that occurred in some marriages but most often did not result in criminal proceedings. ${ }^{49}$ Petitions involving drunkenness, cruelty and failure to maintain or perform domestic duties were gendered in a number of

\footnotetext{
${ }^{44}$ See the discussion in Chapter One on the passing of the 1920 Marriage Act.

${ }^{45} M v M$, AAOM/W3265/D397/1941/ANZ-W

${ }^{46} C v C$, AAOM/W3265/D497/1941/ANZ-W.

${ }^{47} M v M$, AAOM/W3265/D77/1940/ANZ-W.

${ }^{48}$ B $v$ B, AAOM/W3265/D1581/1944/ANZ-W. Another case involved a wife who appeared to be obsessed by religion and wrote long, slightly unintelligible letters to her husband on a variety of religious topics. See $W v W, \mathrm{AAOM} / \mathrm{W} 3265 / \mathrm{D} 457 / 1941 / \mathrm{ANZ}-\mathrm{W}$.

${ }^{49}$ Charlotte Macdonald has found that criminal charges of wife beating were only brought against husbands 'whose violence towards their wives was persistent or particularly severe'. Moreover, wives had to be 'unambiguously an innocent and "legitimate" victim'. See, 'Crime and Punishment in New Zealand, 18401913: a Gendered History'. NZJH 23, no.1 (1989): 5-21. Divorce files are therefore useful in providing evidence of domestic violence that was not heard in criminal cases. Prior to the 1898 Act, wives who petitioned for divorce had to prove aggravated adultery, and this usually was adultery coupled with cruelty. For an examination of marital violence in the period 1890-1900, that is the period leading up to the law change and its early implementation, see S.A. Schofield. 'A Legal History of Marital Violence in Christchurch 1890-1900’. BA(Hons) research essay, University of Canterbury, 2010.
} 
ways. ${ }^{50}$ Firstly, only wives could petition for divorce on the ground of habitual drunkenness of four years or more coupled with either cruelty or failure to maintain, and only husbands could petition for divorce on the ground of four years habitual drunkenness coupled with a failure to perform domestic duties. Legally, cruelty was a marital wrong that could only be committed by husbands. It was only when defending a petition for restitution of conjugal rights that husbands could allege cruelty. In practice, husbands almost never used this ground, whereas wives were frequent users of the ground until the late 1920s. Colin James has found a similar pattern in Australia. ${ }^{51}$ Petitions for divorce on the ground of cruelty and drunkenness diminished markedly from the late 1920s after a sharp post-World War I peak, as shown in Figure 6.1. Women's organisations such as the Women's Christian Temperance Union and Society for the Protection of Women of Children brought public attention to the problems associated with drunkenness. ${ }^{52}$ When

\footnotetext{
${ }^{50}$ There is a wide international literature on the history of domestic violence in the nineteenth and early twentieth centuries. See A. James Hammerton. Cruelty and Companionship. Conflict in Nineteenth-Century Married Life. London: 1992; A. James Hammerton. 'Victorian Marriage and the Law of Matrimonial Cruelty'. VS 33, no.2 (1990): 269-92; Maeve E. Doggett. Wife-Beating and the Law in Victorian England. London: 1992; David Peterson del Mar. What Trouble I Have Seen. A History of Violence against Wives. Cambridge, Mass: 1996; Linda Gordon. Heroes of Their Own Lives. The Politics and History of Family Violence. Boston 1880-1960. New York: 1988; Shani D'Cruze. Crimes of Outrage. Sex, Violence and Victorian Working Women. DeKalb: 1998; Shani D’Cruze, ed. Everyday Violence in Britain, 1850-1950. Gender and Class. Harlow: 2000; Shani D'Cruze. 'Sex, Violence and Local Courts. Working-Class Respectability in a Mid-Nineteenth-Century Lancashire Town'. British Journal of Criminology 39, no.1 (1999): 39-55; Savage, 'A State of Personal Danger', 267-85; Anna Clark. 'Humanity or Justice? Wifebeating and the Law in the Eighteenth and Nineteenth Centuries', in Regulating Womanhood. Historical Essays on Marriage, Motherhood and Sexuality, ed. Carol Smart. London: 1992, 187-206; Carolyn Strange. 'Masculinities, Intimate Femicide and the Death Penalty in Australia, 1890-1920'. British Journal of Criminology 43, no.2 (2003): 310-339; Elizabeth Pleck. 'Feminist Responses to "Crimes against Women," 1868-1896'. Signs 8, no.3 (1983): 451-70; Carol Bauer and Lawrence Ritt. "“A Husband is a Beating Animal". Frances Power Cobbe Confronts the Wife-Abuse Problem in Victorian England'. International Journal of Women's Studies 6, no.2 (1983): 99-118; Carol Bauer and Lawrence Ritt. 'WifeAbuse, Late-Victorian English Feminists, and the Legacy of Frances Power Cobbe'. International Journal of Women's Studies 6, no.3 (1983): 195-207; Jerome Nadelhaft. 'Wife Torture: A Known Phenomenon in Nineteenth-Century America'. Journal of American Culture 10, no.3 (1987): 39-59; Robert L. Griswold. 'The Evolution of the Doctrine of Mental Cruelty in Victorian American Divorce, 1790-1900'. JSH 20, no.1 (1986): 127-48; Robert L. Griswold. 'Law, Sex, Cruelty, and Divorce in Victorian America, 18401900'. American Quarterly 38, no.5 (1986): 721-45; Robert L. Griswold. 'Sexual Cruelty and the Case for Divorce in Victorian America'. Signs 11, no.3 (1986): 529-41; Pamela Haag. 'The "Ill-Use of a Wife": Patterns of Working-Class Violence in Domestic and Public New York City, 1860-1880'. JSH 25, no.3 (1992): 447-77; Annalee E. Lepp. 'Dis/Membering the Family: Marital Breakdown, Domestic Conflict, and Family Violence in Ontario, 1820-1920'. PhD thesis, Queen's University, 2001. As well see works cited below.

${ }^{51}$ Colin James. 'A History of Cruelty in Australian Divorce'. ANZLH E-Journal (2006): 1.

${ }^{52}$ Paul Christoffel has argued that the movement for Prohibition remained strong throughout the 1920s and only went into decline in the 1930s. This is in contrast to previous arguments by Sinclair and Belich who have dated the decline of the Prohibition movement a decade earlier. What this suggests regarding the ground of drunkenness, cruelty and failure to maintain, is that it was the introduction of separation of three years or more as a ground for divorce which reduced petitions on the former ground as a separation order could be obtained from the Magistrates' Court relatively easily and then used in the Supreme Court as
} 
these issues were given less attention in the middle years of the twentieth century, women were far less likely to use such behaviour as a ground for divorce. ${ }^{53}$

Figure 6.1

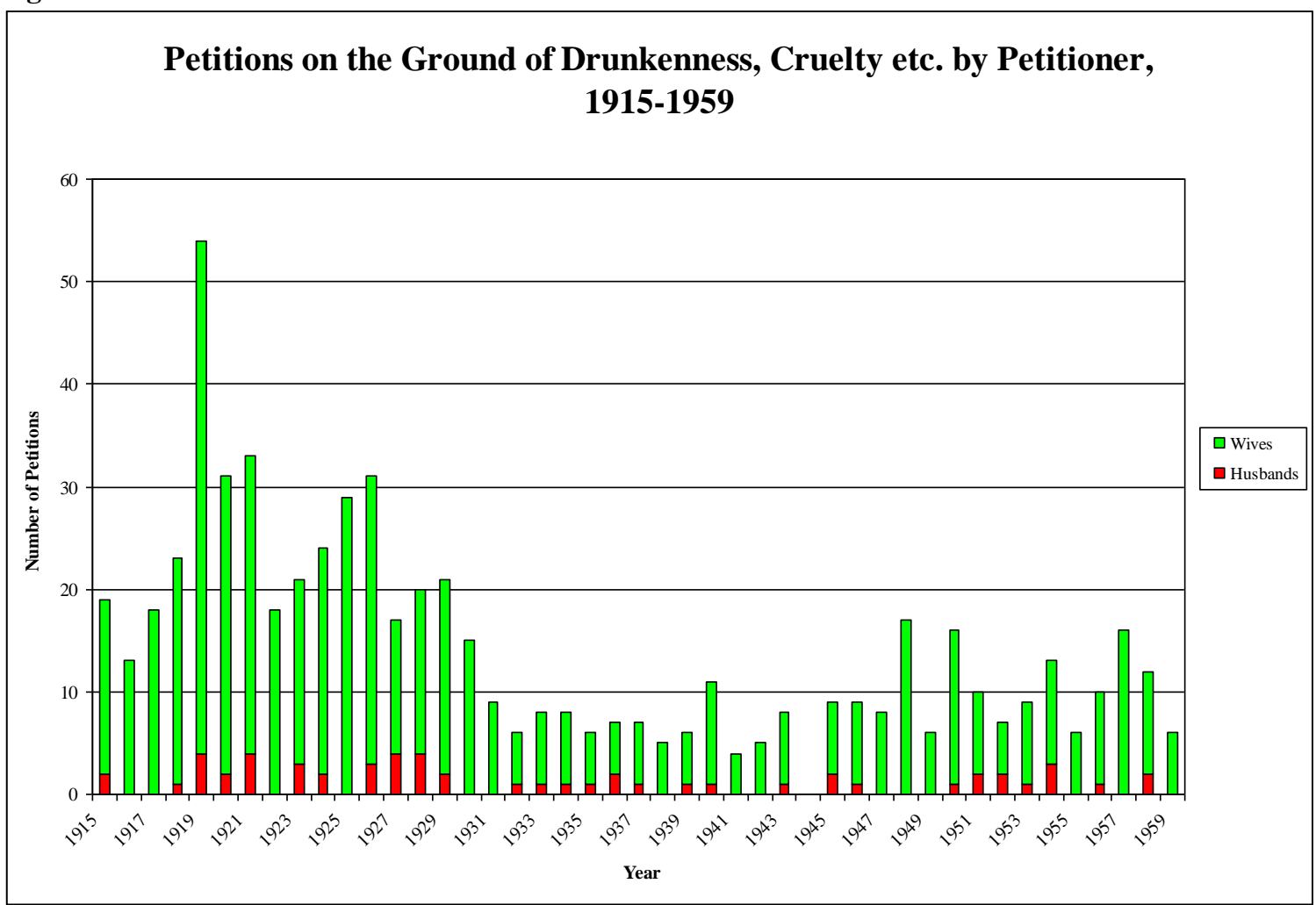

Source: Statistics of New Zealand (data before 1921), Report on Justice Statistics (data from 1921). No data was available for 1944 due to a reduction in the recording of statistics during World War II.

The link between cruelty and drunkenness was clear to late nineteenth century feminists and advocates of divorce law reform. The plight of the battered and abused wife and her children was used to publicise their cause. In practice, however, the ground was not used as frequently as others, no doubt in part because of the heavy burden of proving four years habitual drunkenness and cruelty. At the same time, those petitions which did involve allegations of cruelty, demonstrate how the marital home was a site of violence for many wives and children. The violence was physical, verbal, sexual and at times involved attempts to cause a miscarriage. ${ }^{54}$ The most extreme examples of physical

evidence of a separation. For Christoffel's argument see, 'Prohibition and the Myth of 1919'. NZJH 42, no.2 (2008): 154-75.

${ }^{53}$ Shani D'Cruze has argued that in 1930s Britain, the dominant discourses about violence 'prioritised harm to the child rather than to adult women and saw family violence as mainly a working-class trait'. Shani D'Cruze. 'Intimacy, Professionalism and Domestic Homicide in Interwar Britain: the case of Buck Ruxton'. WHR 16, no.5 (2007): 717.

${ }^{54}$ A.R. Gillis has found a negative association between separation and divorce and premeditated spousal homicide in France as unhappy couples were able to divorce and did not have to resort to more extreme ways of ending their marriages. It is possible that a similar pattern occurred in New Zealand. See 'So Long 
violence in the divorce case files include threats or attempts to murder. In 1898 Andreas W. applied for a restitution of conjugal rights from his wife Monika. In her answer she claimed that he had been repeatedly cruel to her and this was the reason for her leaving him. In particular she claimed:

(b) On the $13^{\text {th }}$ December 1896 the petitioner used threatening and abusive language towards the respondent and threatened to kill her wherefore she was compelled to seek protection with neighbours...

(d) On the $14^{\text {th }}$ March 1897 the petitioner endeavoured to compel the respondent to submit to him whilst she was unwell and that he abused her and threatened to kill her and subsequently for weeks prevented her from sleeping in her own bed.

(e) On the $21^{\text {st }}$ day of June 1897 the petitioner threatened to kill the respondent.

(f) On the $2^{\text {nd }}$ August 1897 the petitioner threatened to shoot the respondent and kill her and endeavoured to compel her to go out and drive cattle when she was too ill to do so...

(i) On the $23^{\text {rd }}$ October 1897 the petitioner caught the respondent by the throat in the presence of her daughter and threatened to kill her and knocked her head against a mantelpiece. ${ }^{55}$

Andreas did not pursue his petition, so the case was never heard by the court. It is likely, had the case gone to court, that his wife's allegations of continual cruelty meant that he would have had difficulty in securing a restitution for conjugal rights. The couple had been married in Germany and perhaps migrated to New Zealand without other family members, meaning that Monika had little familial support to rely on if she left Andreas, resulting in her tolerating behaviour that she may not have otherwise. While most allegations were made by the wives themselves, sometime children gave evidence against their fathers, and sometimes husbands admitted to the violence themselves suggesting that they felt justified in their actions and blamed their wife's behaviour for provocation.

There appears to be a difference in the way violence towards wives was considered in Australia compared to New Zealand. Australian courts 'often dismissed the allegations of men's cruelty in women's petitions for judicial separation or divorce and encouraged women to return to their husbands and to adopt a more submissive attitude'. ${ }^{56}$ No evidence of this attitude has been found in cases examined from the Wellington Supreme

as They Both Shall Live: Marital Dissolution and the Decline of Domestic Homicide in France, 1852-1909'. The American Journal of Sociology 101, no.5 (1996): 1273-1305. In contrast, Michael Gilding has found that in 1930s Australia, a rising proportion of wife murders were precipitated by the wife's desertion or threat to desert her husband. See The Making and Breaking of the Australian Family. Sydney: 1991, 42.

${ }^{55} W v W$, AAOM/W3265/D277/1898/ANZ-W. For a case from later in the study period see $H v H$, AAOM/W3265/D344/1947/ANZ-W.

56 James, 1. 
Court. Jo Aitken's argument that in Australia, 'women were often constructed not as the direct victims of male violence or drinking but as the defenders of children against these scourges', in part explains this attitude. Women were primarily considered to be defenders of the home and nation, rather than victims of men. ${ }^{57}$ The New Zealand divorce files show wives being constructed both as direct victims of their husbands' violence and as defenders of their children.

The fact that drunkenness alone was not a ground for divorce but had to be accompanied by either, cruelty, failure to maintain or failure to perform domestic duties shows the assumption by many politicians that the different acts were related, or that drunkenness was tolerable as long as it did not impact upon men's ability to carry out their expected role as provider and defender of the family. Cruelty alone was not a ground for divorce unless accompanied by habitual drunkenness. In 1947 Enid P. told the court that after attending a party with her husband and having to 'just about carry him home' as he was so drunk, he punched her as she tried to help him prepare for bed and gave her two back eyes. His violence, however, was not limited to the times when he was drunk. He returned home one evening, sober, after trying unsuccessfully to obtain a job and pulled the evening meal and the tablecloth off the table. ${ }^{58} \mathrm{Had}$ all his violent behaviour occurred without him being a habitual drunkard, his wife would not have had grounds for divorce.

Some husbands quite readily told the court they had physically assaulted their wives suggesting they believed they were justified in doing so. One husband in 1920 said, 'I have never struck my wife. I have shaken her...I once put my hand over her mouth to stop her from nagging, ${ }^{59}$ Clearly, he thought that a certain amount of physical contact was acceptable and justified because of his wife's behaviour. The fact that he was granted a divorce and the co-respondent was ordered to pay him $£ 1,000$ suggests the court supported his view. Similarly, in 1947 Eric H. freely admitted to the court that he had assaulted his wife, 'My wife speaks of one assault on her. It would be about 7-8 months before she left me. I remember it. I had been locked out of the house by her. I slapped her when I got in. I smacked her or slapped her'. ${ }^{60} \mathrm{He}$ had petitioned for a divorce on the

\footnotetext{
${ }^{57}$ Jo Aitken. "“The Horrors of Matrimony Among the Masses": Feminist Representations of Wife Beating in England and Australia, 1870-1914'. JWH 19, no.4 (2007):119-20.

${ }^{58} P$ v $P$, AAOM/W3265/D21/1947/ANZ-W.

${ }^{59} P$ v $P$ \& B, AAOM/W3265/D1971/1920/ANZ-W.

${ }^{60} H v H$, AAOM/W3265/D413/1947/ANZ-W.
} 
ground of failure to comply with a restitution of conjugal rights and the court found in his favour, suggesting that the court's view was that the wife did not have reasonable grounds for staying away from the marital home, as 'only' one violent incident was brought to the court's attention and it was a 'punishment'. While the wife may have been happy to be divorced from her husband, being the respondent, rather than the petitioner in the case, would have cast her in the role of the 'guilty' party and made it more difficult to secure maintenance and custody of her children. ${ }^{61}$

Despite marital rape not being made illegal in New Zealand until 1985, husbands did not have absolute and unlimited access to their wives' bodies. ${ }^{62}$ Some wives complained about their husbands' sexual mistreatment of them. In other situations, wives complained of, but did not explicitly describe, the nature of the assault. James Hammerton has argued that a large number of acts of cruelty took place in bedrooms and especially in beds, suggesting a sexual element to the dispute. ${ }^{63}$ This appears to be the case in New Zealand. For example, in 1903, Emma P. claimed her husband 'violently took hold of your petitioner while she was in bed and screwed her eyes round so that your petitioner was nearly blinded causing her a great deal of pain and suffering' ${ }^{64}$ She did not pursue her petition, so the court's view of such violence is unknown. What is clear is some husbands refused to accept their wives declining to have intercourse, forcing their wives or responding with another form of physical violence.

One of the reasons wives tried to avoid intercourse was the fear of pregnancy which often provoked their husbands' rage if pregnancy was unwanted. In such cases, husbands sometimes tried to make wives have an abortion or assaulted them in such a way to induce a miscarriage. In 1900, Leah A. petitioned for divorce on the ground of her husband's adultery and cruelty. After telling her husband she was pregnant, he tried to make her have an 'operation for causing abortion' but she refused. He then gave her drugs

\footnotetext{
${ }^{61}$ In this particular case there was no order for custody despite there being two young children of the marriage. Likewise, no maintenance order was made.

${ }^{62}$ Crimes Amendment Act (No.3) 1985. Gail Savage has found that the Divorce Court in England placed similar limitations on husbands. See '...the instrument of an animal function': Marital Rape and Sexual Cruelty in the Divorce Court, 1858-1908', in The Politics of Domestic Authority in Britain since 1800, eds. Lucy Delap et al. Houndmills: 2009, 43-57; Also, see Rebecca M. Ryan. 'The Sex Right: A Legal History of the Marital Rape Exemption'. Law \& Social Inquiry 20, no.4 (1995): 941-1001.

${ }^{63}$ Hammerton, 108-9. See also Joanna Bourke. 'Sexual Violence, Marital Guidance and Victorian Bodies: An Aesthesiology'. VS 50, no.3 (2008): 419-36.

${ }^{64} P \vee P$, AAOM/W3265/D590/1904/ANZ-W.
} 
which would cause a miscarriage and threatened her with violence if she refused to take them. He also tried to force her to jump off a chair. ${ }^{65}$ In 1941 Florence M. told the court she had left her husband John because he physically attacked her while she was pregnant after she 'taxed' him about his conduct with other women, and later because he taught one of their children a 'filthy' rhyme. ${ }^{66}$

Sometimes it was the violence directed at, or the mistreatment of children that made wives decide to leave their husbands. One wife, Martha J., who left her husband in 1898 after his numerous acts of violence towards her and their four children, originally tried to support her family by doing needlework, as her husband would not pay her any maintenance. When this income failed to cover the rent, she took a position as a housekeeper with a widower who was prepared to provide food and accommodation for her and her children, and pay her five shillings a week. She then began a relationship with her employer. Her husband petitioned successfully for divorce on the ground of adultery and the co-respondent was ordered to pay $£ 50$ damages. ${ }^{67}$ Even though her husband's behaviour was responsible for her leaving the marital home, the judge still ruled her adultery caused the end of the marriage as it was considered a more serious violation of the marital vows, and allowed her husband to seek damages from the man who was helping to support his children.

Husbands were far less likely to make allegations of cruelty against their wives, as cruelty by a wife did not constitute a ground for divorce. In some cases, however, husbands could defend their behaviour by alleging cruelty by their wife. For example, in 1923 Maud N. filed for a restitution of conjugal rights from her husband William. The couple had married in Wellington in 1916 and had two children. In his answer, William made a number of allegations about Maud's behaviour, and denied abandoning Maud. He claimed they had separated by mutual consent in May 1920 and that Maud had gone to England to live. She had returned to New Zealand in September 1922 without consulting her husband and he allowed her to stay at his house but they 'did not live as man and wife'. In November William left their home as a result of Maud's violent behaviour. He listed numerous instances of cruelty on her part and claimed that she had 'pursued a

\footnotetext{
${ }^{65} A v A$, AAOM/W3265/D338/1900/ANZ-W.

${ }^{66} M v M$, AAOM/W3265/D397/1941/ANZ-W. John also threatened his wife with extreme violence, lifting an axe at her and saying that he would 'bash her brains out'.

${ }^{67} J v J \& M$, AAOM/W3265/D306/1899/ANZ-W.
} 
course of conduct calculated to break the Respondent's spirit and to cause his health to break down'. A number of specific examples of Maud's cruelty were given, including, 'when the younger child of the Petitioner and the Respondent was a few months old the Petitioner slapped the Respondent in the face with the child's dirty napkins covering the Respondent with filth'. As well, in 1919 'the Petitioner attacked the Respondent with a carving knife whilst the Respondent was having breakfast and endeavoured to do him grievous bodily harm. About this time it was quite a common thing for the Petitioner to attack the Respondent with knives or scissors'. On another occasion Maud 'smashed up the Respondent's piano with a heavy axe'. She also assaulted his children from his first marriage, and he was forced to send them to boarding school to protect them. ${ }^{68}$ Clearly wives were capable of acts of violence and cruelty, although women were less likely to behave in such a manner than husbands. Some husbands may have been reluctant to admit that they had been the victim of a physical assault by their wives as it cast into doubt their masculinity. While there was a public discourse about male violence towards women for wives to draw on, no such discourse existed for husbands to utilise.

Another problem for wives associated with obtaining a divorce on the ground of drunkenness and cruelty or failure to maintain was the requirement to prove four years of habitual drunkenness. In a number of cases lawyers argued that while the husband had been drunk frequently, he had not been drunk habitually. ${ }^{69}$ In 1951 a wife was refused a divorce on the ground of her husband's drunkenness and cruelty by Justice Gresson as she could not prove that he had been guilty of habitual drunkenness for four years or more. The couple had been married on 24 December 1945, and the judge dated Mr Brown's drunkenness from a month after this date. He had been arrested, however, on 10 November 1949 for murder and convicted in February 1950. Once he was in custody he was no longer able to drink. ${ }^{70}$ Mrs Brown not did have grounds for divorce despite her husband being a habitual drunkard for almost four years and also having been convicted of murder. In 1953 conviction of murder did become grounds for divorce, and she would have been able to obtain a divorce then.

\footnotetext{
${ }^{68} N v N$, AAOM/W3265/D2444/1923/ANZ-W.

${ }^{69}$ For examples see, Dempsey v Dempsey, [1905] NZLR, 829-31; Korth v Korth, [1913] NZLR, 290-93; Thomas $v$ Thomas [1916] NZLR, 676-78.

${ }^{70}$ Brown v Brown, [1951] NZLR, 715-18.
} 
While the majority of cases involving the ground of drunkenness also included cruelty, some involved failure to maintain as a ground as well. ${ }^{71}$ While the failure to maintain did not have to be a direct result of excessive alcohol consumption, usually it was. In 1944 Irene K. told the court her husband had 'failed to bring home any money' from the beginning of their marriage. She had been in paid employment throughout their marriage and had to also seek financial assistance from other people. Rather peculiarly, when she left her husband he asked if she wanted maintenance but she said, 'if he couldn't keep me before he couldn't pay me maintenance'. ${ }^{72}$ Even in the 1940s when an increasing number of married women were in paid employment, it was interpreted as a failure on the part of the husband if his wife was forced to go to work through his failure to provide adequate financial support. ${ }^{73}$

A husband's drunkenness could also impact directly on his wife's ability to earn an income. In 1947 Elsie W. petitioned for divorce on the ground of her husband's cruelty and drunkenness. ${ }^{74}$ She told the court, 'Since our marriage my husband has been drinking regularly and consistently...He gets drunk on Fridays, Saturdays and his pay day, every second Wednesday'. Elsie was the proprietor of an apartment house and her husband was abusive towards her lodgers. She claimed that his drinking affected her business and she had 'lost most of [her] best tenants through him'. ${ }^{75}$ She had had to call the police to her home more than a dozen times and her health had also suffered as a result of his behaviour. Not only did her husband fail to provide financially for her, he made it very difficult for Elsie to provide an income for herself.

Many wives, and some husbands, claimed their spouses' drunkenness and cruelty was so extreme it had had a detrimental impact on their physical and mental health. This evidence was seen as further proof of unacceptable behaviour by the respondent. For example, Hilda C. told the court in 1947 that her husband 'was very abusive. He was

\footnotetext{
${ }^{71}$ Annabel Cooper has argued that from the late nineteenth-century there was an expectation in New Zealand that married men would be the sole breadwinner for the family. This expectation, while often not realised, was embodied in the inclusion of failure to maintain (coupled with habitual drunkenness) as a ground for divorce in 1898. See Annabel Cooper. 'Poor Men in the Land of Promises. Settler Masculinity and the Male Breadwinner Economy in Late Nineteenth-Century New Zealand'. AHS 39, no.2 (2008): 24561.

${ }^{72} K v K$, AAOM/W3265/D1431/1944/ANZ-W.

${ }^{73}$ This case also demonstrates that it was difficult for women to support themselves financially, and Irene had to also rely on assistance from others to do so even though she did not have any children.

${ }^{74}$ This was Elsie's third divorce and her husband's second divorce.

${ }^{75} W v W, \mathrm{AAOM} / \mathrm{W} 3265 / \mathrm{D} 57 / 1947 / \mathrm{ANZ}-\mathrm{W}$.
} 
drinking heavily and not coming home at night...He was always threatening me, and arguing over my two children of a previous marriage. He didn't like them. If I raised any objection to his conduct, he always told me I could get out if I didn't like the way I was treated. In August I had a bad nervous breakdown'. ${ }^{76}$ She successfully obtained a divorce on the ground of separation of three years or more. Enid P., whose husband's drunken behaviour had resulted in them being evicted from a number of boarding houses told the court, 'I have been in hospital and I have been told by my medical advisors that my illness was caused by the worry' ${ }^{77}$ Such claims increased over the twentieth century suggesting there was a growing acceptance of the multiple problems that alcoholism could cause, and a greater willingness to admit to having suffered poor mental health as a result of living with an alcoholic.

\section{Figure 6.2}

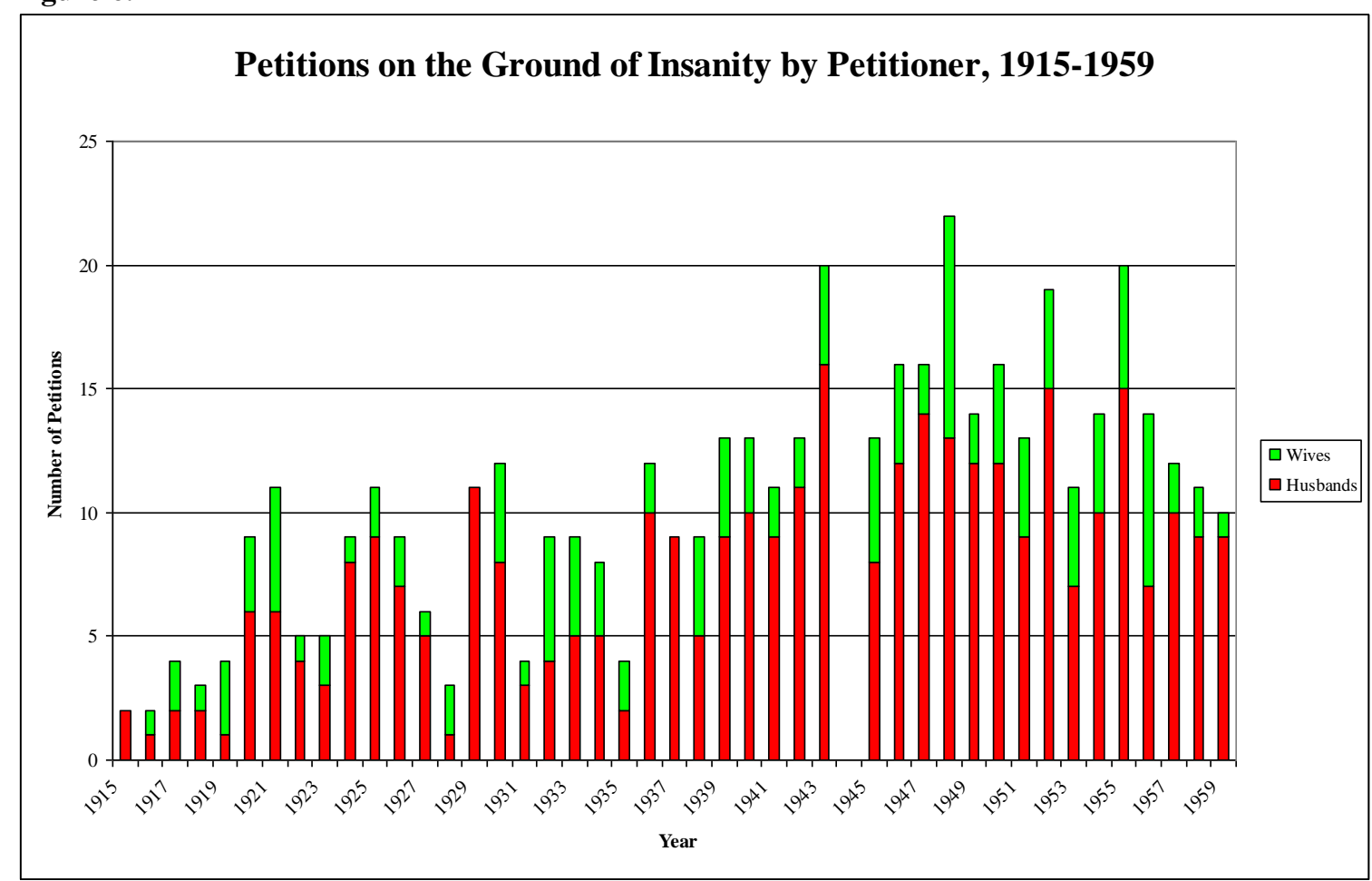

Source: Statistics of New Zealand (data before 1921), Report on Justice Statistics (data from 1921). No data was available for 1944 due to a reduction in the recording of statistics during World War II.

While there was a growing acceptance of temporary poor mental health, especially that which could be ascribed to an obvious cause, those who were considered to be permanently of an 'unsound mind' could be divorced by their spouse. Insanity, like

\footnotetext{
${ }^{76} C v C$, AAOM/W3265/D25/1947/ANZ-W.

${ }^{77} P \vee P$, AAOM/W3265/D21/1947/ANZ-W.
} 
drunkenness and cruelty, was a ground that was not used by many petitioners, but the pattern of petitioning was highly gendered. As Figure 6.2 shows, husbands were far more likely to petition for divorce on this ground than wives. A comparable pattern has been identified in Victoria, Australia during a similar period. ${ }^{78}$ As outlined in Chapter One, insanity became a ground for divorce in 1907 as evidenced by internment in an asylum for ten of the previous twelve years - in 1912 this was reduced to internment for seven of the previous ten years. This requirement explains why there were so few petitions on this ground. No other ground for divorce required waiting such a long period of time before petitioning, and in some cases while a spouse was in an asylum another ground for divorce was used in order to avoid having to wait such a long period of time. ${ }^{79}$ Some spouses were prepared to wait the required time to petition on the ground of insanity perhaps because their situation did not qualify for any of the other legal grounds for divorce.

There were concerns when insanity first became a ground for divorce that some husbands would have their wives unfairly committed to an asylum in order to obtain a divorce. ${ }^{80}$ While there is little evidence of this being a significant problem - no doubt because of the long period of confinement necessary before a petition for divorce could be filed, there were some husbands who used the potential to be committed to an asylum as a threat. In 1921 James O. petitioned for divorce on the ground of his wife's desertion in 1905. Elizabeth O. claimed she had not wilfully deserted her husband, but had been forced to leave him due to his behaviour towards her. In his judgment Justice Hosking summarised the situation,

My conclusion from the evidence, and I accept hers in this respect, is that she was threatened with the asylum. The husband in cross-examination said "I threatened to send her to the asylum because I had to threaten something."...I believe the Petitioner was only too ready to be rid of his wife because they could not get on together and that she was threatened as she states. In my view her flight from home was not with the intention of deserting but temporarily escaping from the fear she was under. ${ }^{81}$

\footnotetext{
${ }^{78}$ Margaret James. 'Double Standards in Divorce. Victoria, 1890-1960', in In Pursuit of Justice. Australian Women and the Law 1788-1979, eds. Judy Mackinolty and Heather Radi. Sydney: 1979, 209.

${ }^{79}$ For examples see $C v C \& G$, AAOM/W3265/D2741/1946/ANZ-W; $A v A$, AAOM/W3265/D1161/1943/ ANZ-W; $L v L$, AAOM/W3265/D365/1947/ANZ-W; $C v C$, AAOM/W3265/D1303/1915/ANZ-W; $P v P$, AAOM/W3265/D69/1947/ANZ-W; $M-R v R$, AAOM/W3265/D5709/1939/ANZ-W.

${ }^{80}$ Roderick Phillips. Divorce in New Zealand: A Social History. Auckland: 1981, 38.

${ }^{81} O$ v $O$, AAOM/W3265/D2183/1921/ANZ-W.
} 
The petition was dismissed. Reflective of more general power dynamics, men were the primary informants for the committal to an asylum of both men and women, making it far more difficult for a wife to threaten and to follow through with having her husband committed without justification.

A variety of studies of insanity in New Zealand and Australia during the late nineteenth and the first half of the twentieth century have identified a number of common features of the committal and incarceration of patients. ${ }^{82}$ Firstly, families played the greatest role in the committal of patients. ${ }^{83}$ Most doctors who signed the medical certificates required to commit an individual were not psychiatrists, but general practitioners. Often not the patient's usual general practitioner, these doctors were making judgements based on one meeting and the views of family members. As Bronwyn Labrum argues, '[t]he doctors largely confirmed, and gave legitimacy to decisions already made by others. It was principally family, friends and neighbours who instigated proceedings or allowed them to continue'. ${ }^{84}$ It was men who were the primary suppliers of information related to committals, and women's evidence was almost always corroborated by men. ${ }^{85}$ While single people were more likely to be committed to an asylum than their married counterparts, married people were not exempt. ${ }^{86}$ Brookes found men were more likely to be committed to asylums than women, further complicating attempts to explain the pattern of divorce on the ground of insanity. ${ }^{87}$

Brookes has drawn attention to the connections between alcoholism and insanity, particularly for men. Between 1898 and 1902 about 16 per cent of male admissions to

\footnotetext{
${ }^{82}$ These studies include Catharine Coleborne. Madness in the Family. Insanity and Institutions in the Australasian Colonial World, 1860-1914. Houndmills: 2010; Judith Holloway. "Unfortunate Folk." A Study of the Social Context of Committal to Seacliff, 1928-1937', in 'Unfortunate Folk'. Essays on Mental Health Treatment 1863-1992, eds. Barbara Brookes and Jane Thomson. Dunedin: 2001, 153-67; Barbara Brookes. 'Women and Madness: A Case-study of the Seacliff Asylum, 1890-1920', in Women in History 2, eds. Brookes et al. Wellington: 1992, 129-47; Jill Julius Matthews. Good and Mad Women. The Historical Construction of Femininity in Twentieth-Century Australia. Sydney: 1984; Bronwyn Labrum. 'Looking Beyond the Asylum. Gender and the Process of Committal in Auckland, 1870-1910'. NZJH 26, no.2 (1992): 125-44 and 'Gender and Lunacy. A Study of Women Patients at the Auckland Lunatic Asylum 1870-1910'. MA thesis, Massey University, 1990.

${ }^{83}$ Brookes, 'Women and Madness', 131.

${ }^{84}$ Labrum, 'Looking Beyond the Asylum', 129. Judith Holloway found a similar pattern in her study where only eight of 104 women's committals were initiated by outside agencies. See Holloway, 154-55.

${ }^{85}$ Labrum. 'Gender and Lunacy', 97.

${ }^{86}$ Holloway, 160-62.

${ }^{87}$ Brookes, 'Women and Madness', 136.
} 
asylums was the result of alcoholism. ${ }^{88}$ It is possible wives, who divorced their husbands who were institutionalised, used the ground of drunkenness coupled with either cruelty or failure to maintain rather than insanity. Alternatively, wives of alcoholics may have been satisfied with having their husbands institutionalised as a solution to the problem, and not felt the need to have their marriage dissolved as long as their husband remained in the asylum.

Not surprisingly, as men were usually the primary informants in committing an individual, husbands were far more likely to have their spouse committed to an asylum than wives. ${ }^{89}$ This may have contributed to more husbands petitioning for divorce on the ground of insanity, as they were more likely to have had their wife committed in the first place. Most married women were committed for having breached the 'domestic ideal' in some way. ${ }^{90}$ Jill Matthews has argued that in twentieth-century Australia women who were defined as mad had failed in the pursuit of femininity encompassing monogamous legal marriage, performing household duties or mothering. ${ }^{91}$ Bronwyn Labrum has found a similar pattern in late-nineteenth and early-twentieth century Auckland. ${ }^{92}$ According to Judith Holloway, women committed to Seacliff Asylum were often described as 'no longer manageable at home'. Their families explained their illness by providing examples of their neglect of housework and children, and this was accepted as evidence of their madness. ${ }^{93}$ While failing in their duties in the home was a major reason for women's incarceration in asylums, Brookes has asserted that 'women's location in the home protected them from being institutionalised'. ${ }^{94}$ At the same time, cure rates were higher for women patients and this was attributed to the rest and improved diet some women received in the asylum. ${ }^{95}$ This is indicative of the negative impact that marriage had on some women. Coleborne found in her study's sample that most patients were eventually discharged, many after a number of months. ${ }^{96}$ As outlined above, those who were divorced on the ground of insanity had to be institutionalised for ten, and then later seven years. This means that those who were divorced on the ground of insanity form a

\footnotetext{
${ }^{88}$ Brookes, 'Women and Madness', 132.

${ }^{89}$ Labrum, 'Gender and Lunacy', 95.

${ }^{90}$ Holloway, 154-55; Also see Coleborne, 77-78.

${ }^{91}$ Matthews, 109-97.

${ }^{92}$ Labrum. 'Looking Beyond the Asylum', 136.

${ }^{93}$ Holloway, 160.

94 Brookes, 'Women and Madness', 136.

${ }^{95}$ Labrum. 'Looking Beyond the Asylum', 143.

${ }^{96}$ Coleborne, 131.
} 
relatively small subgroup of all those individuals who were institutionalised at some point in their life, and points to the need for further studies which focus on those who were institutionalised and eventually divorced.

Husbands and wives entered marriage with many and differing expectations. Often these expectations were not met and the ensuing disappointment sometimes eventually led to an unloosening of the marriage and one spouse petitioning for divorce. Money, socialising, the performance of household duties by wives, living arrangements and religion were all sources of tension in many marriages. Gender played a primary role in people's expectations of marriage as demonstrated in the different stance husbands and wives took on issues of contention.

Some grounds for divorce were used in highly gendered ways. The ground of drunkenness coupled with either cruelty or failure to maintain in the case of husbands, or failure to perform domestic duties in the case of wives, was explicitly gendered and the legislation outlined expected roles of husbands and wives. The ground was also gendered in that the vast majority of petitioners who used this ground were wives suggesting that male drunkenness was more prevalent and more problematic for marriages than female drunkenness. Conversely, husbands were more likely to petition for divorce on the ground of insanity than wives. Husbands may have found it easier to have their wives committed to asylums, and wives may have been more reluctant to have their husbands committed if they were the only source of financial support. Many women who were committed to asylums had failed in some way in the 'pursuit of femininity' and this may have further contributed to their husbands' desires to divorce them and to seek another wife.

Whatever the causes of a specific divorce, the court records often reveal conflicts between different expectations about masculinity and femininity. The male homosocial world, and the heterosexual world, constricted opposing views of masculine identities which caused conflict between husbands and wives. While the homosocial networks of women did not conflict with the identity of women as wives, there was an increasing demand by women for more pleasure in their lives which domesticity did not provide. In the midst of these conflicts, often exacerbated by wartime, wives and husbands might decide that divorce was a preferable option to remaining in an unsatisfactory relationship. 


\section{Chapter Seven}

\section{For the Sake of the Children: Children's Part in Divorce Proceedings}

Divorce involved the children of the marriage, and potentially altered their lives. Children were often cited as the main purpose of marriage and the tie that bound marriages together. Unhappy couples often received advice to keep their marriages together for the 'sake of the children'. Such advice does appear to have offered a major reason for couples to persevere in their marriages. Analysis of the Wellington Divorce Database reveals that divorcing couples had far fewer children on average than the population as a whole. This was most likely not necessarily because married couples with children found greater happiness in marriage than those without children, but because the need to provide a secure financial and emotional environment in which to raise children meant that couples made an extra effort to remain married. If an unplanned pregnancy had forced the couple to marry, however, it was more likely to end in divorce than those whose marriages did not begin for this reason. When the marriage was a second or later relationship for one or both spouses, there were sometimes added tensions due to the existence of children from the previous union. A sense of divided loyalty between one's children and one's new spouse could be problematic. Generally, if pressed to make a choice, most people chose their children over their spouse and this led to marriages breaking down. Combined, this evidence points to the fluid, complex and unstable nature of families even with the apparently binding presence of children.

The ending of a marriage had an enormous impact on the children of the divorcing couple, especially those still financially dependent and living in the family home. Children sometimes participated in the main theatre of conflict - the court - when they gave evidence against a parent, usually their father. They also experienced the consequences of divorce in issues such as custody. In almost three quarters of the cases in the Wellington sample, wives as mothers were awarded the guardianship of their children, confirming women's role as the primary caregiver of children, but potentially reducing the children's contact with their fathers. Children thus took on various roles in the process of divorce 
from proximate cause of an unhappy union to creators of marital tensions to witnesses, to pawns and, possibly, victims.

From 1913 the New Zealand Year Book recorded the number of shot gun marriages, indicating a concern with this phenomenon. Of all marriages formed in 1919, 10 per cent produced a child in the first seven months, but by 1945 this figure had decreased to slightly less than eight per cent. In the Wellington divorce sample, however, slightly more than 21 per cent of marriages involved a baby being born in the first seven months of marriage (Table 7.1). Even more interestingly, the number of shot gun marriages ending in divorce increased as a proportion of all divorces at the same time as 'shotgun' marriages decreased in the population as a whole. Clearly the pressures that forced such couples to marry did not ensure their happiness or the survival of the relationship once societal expectations had been assuaged by the legitimating of the child conceived before the wedding. The change over time points to the growing importance of emotional satisfaction as a requirement for successful marriages while the presence of children no longer persuaded unhappy couples to remain together.

Table 7.1

Number of divorce petitions where the first child was born within the First Seven Months of marriage (or prior to the marriage) as a Percentage of all Divorce Petitions $(N=2166)$

\begin{tabular}{c|c|c}
\hline Petition Year & $\begin{array}{c}\text { As a percentage of } \\
\text { all divorce petitions }\end{array}$ & $\begin{array}{c}\text { Number of } \\
\text { 'Shotgun' } \\
\text { Marriages }\end{array}$ \\
\hline $\mathbf{1 8 9 8}-\mathbf{1 9 0 2}$ & 5.55 & 3 \\
$\mathbf{1 9 0 3}-\mathbf{1 9 0 7}$ & 6.67 & 6 \\
$\mathbf{1 9 0 8}-\mathbf{1 9 1 2}$ & 8.57 & 6 \\
$\mathbf{1 9 1 3}-\mathbf{1 9 1 7}$ & 23.66 & 22 \\
$\mathbf{1 9 1 8}-\mathbf{1 9 2 2}$ & 18.84 & 39 \\
$\mathbf{1 9 2 3}-\mathbf{1 9 2 7}$ & 22.56 & 44 \\
$\mathbf{1 9 2 8}-\mathbf{1 9 3 2}$ & 21.88 & 49 \\
$\mathbf{1 9 3 3}-\mathbf{1 9 3 7}$ & 24.72 & 66 \\
$\mathbf{1 9 3 8}-\mathbf{1 9 4 2}$ & 22.87 & 78 \\
$\mathbf{1 9 4 3}-\mathbf{1 9 4 7}$ & 23.2 & 145 \\
\hline TOTAL & $\mathbf{2 1 . 1 4}$ & $\mathbf{4 5 8}$ \\
\hline
\end{tabular}

Source: Wellington Divorce Database

Aware that 'shotgun' marriages were more likely to end in divorce than other marriages, judges sometimes questioned the parties to a divorce suit in court about the origins of 
their marriage. Some spouses voluntarily informed the court that their marriage was the result of an unplanned pregnancy. In 1932 Miriam G. told Ernest M. that she was pregnant so they married on 16 June 1932 at the City Mission Chapel in Wellington when the bride was 16 and the groom, 24 years old. Five days later, the bride left the groom. She gave birth to their only child, Anthony in February the following year. ${ }^{1}$ Thirteen years later, the couple ended up in the divorce court. The actual marriage as a relationship had lasted less than a week, serving only the purpose of giving the child a legallyrecognised father.

Other couples did not marry until after their child was born. From 1894 couples could legitimise children born out of wedlock by their subsequent marriage. ${ }^{2}$ An illegitimate child, however, could not be made legitimate if at the time of the birth there was a legal impediment to the marriage of the parents. The Legitimation Amendment Act 1921 removed this restriction. ${ }^{3}$ In 1947 Phyllis Y. explained to the court the she had married Gum Wah Y., a Chinese man, in April 1943 to legitimise their daughter who had been born in March 1939. She said, 'I was not to receive maintenance for myself, he agreed to maintain the child; to pay $£ 1$ a week'. She petitioned for divorce on the ground of separation of three years or more. ${ }^{4}$ Phyllis could have sought maintenance from Gum Wah through the Magistrates' Court without marrying him, but marriage provided the advantage of legitimising her daughter.

The vast majority of people who married in the first half of the twentieth century expected to have children unless they married relatively late in life. Even if they did not particularly desire children, a combination of societal expectations and unreliable birth control made the arrival of children most likely. When couples were unable to agree on whether to have children or not, or on how many children to have, this could become a source of tension in the marriage, and ultimately play a part in the demise of the marriage. In 1922, George M. petitioned the court for a divorce on the ground of his wife's desertion. He had married Doris A. in 1913, and George told the court his wife 'seemed to have an aversion to having any children. When we were first married she suggested

\footnotetext{
${ }^{1}$ Mv M, AAOM/W3265/D2253/1945/ANZ-W.

${ }^{2}$ Legitimation Act 1894 (58 Victoriae 1894 No.28).

${ }^{3}$ Legitimation Amendment Act 1921 (12 GEO V 1921 No. 49); J.L. Robson, ed. New Zealand. The Development of its Laws and Constitution. $2^{\text {nd }}$ ed. London: 1967, 454.

${ }^{4} Y v Y$, AAOM/W3265/D309/1947/ANZ-W.
} 
that she would not like to have any children for the first three years. I consented to that thinking that it was a fair thing. In October 1917 she expressed a desire to have a child. Prior to that she was always hostile to sexual relations'.5 In July 1918, a daughter, the only child of the marriage, was born. Doris contradicted her husband's claim telling the court, 'He said he wanted a child to keep him out of Camp. When I was six weeks pregnant he sent me down to Dr. Perkins to get a certificate so as to keep him out of Camp till after the confinement. It is not right that I was averse to having children. I say that it was the other way round'. ${ }^{6}$ George and Doris's disagreement show how disputes about children created marital problems but also revealed the social assumptions that made both spouses reluctant to admit that they did not want children. In addition, the use of the pending birth of a child to avoid military service was not a motive George would want to admit while Doris could use it to impugn her husband's reputation. Their exchange also points to potential for conflicts over sexual intercourse in an era without reliable contraception. ${ }^{7}$ As a couple with only one child, they belonged to the second largest group dissolving their marriages. This group constituted almost thirty per cent of the sample as shown in Table 7.2.

Table 7.2

Number of Children to Each Divorcing Couple, 1898-1947

\begin{tabular}{r|c|c}
\hline $\begin{array}{c}\text { Number of } \\
\text { Children }\end{array}$ & $\begin{array}{c}\text { As a percentage of } \\
\text { all divorces }\end{array}$ & Number of Couples \\
\hline $\mathbf{0}$ & 33.06 & 716 \\
$\mathbf{1}$ & 29.50 & 639 \\
$\mathbf{2}$ & 17.77 & 385 \\
$\mathbf{3}$ & 9.42 & 204 \\
$\mathbf{4}$ & 4.85 & 105 \\
$\mathbf{5}$ & 2.54 & 55 \\
$\mathbf{6}$ & 1.52 & 33 \\
$\mathbf{7}$ or more & 1.34 & 29 \\
\hline Total & $\mathbf{1 0 0}$ & $\mathbf{2 1 6 6}$ \\
\hline
\end{tabular}

Source: Wellington Divorce Database

\footnotetext{
${ }^{5} M v M$, AAOM/W3265/D2295/1922/ANZ-W.

${ }^{6}$ Ibid.

${ }^{7}$ The declining birth-rate from the late nineteenth century until the post-World War II 'Baby Boom' is evidence of more and more couples practising some form of fertility control. However, information about and access to reliable methods was not universal, and abortion played a significant role in the declining birth rate. It was not until the introduction of the contraceptive pill in New Zealand in 1961 that (married) women had access to reliable, women-controlled contraception. For a history of contraception in New Zealand see, Helen Smyth. Rocking the Cradle. Contraception, Sex and Politics in New Zealand. Wellington: 2000. For the role that abortion played in controlling the birth rate see, Barbara Brookes. 'Housewives' Depression. The Debate over Abortion and Birth Control in the 1930s'. NZJH 15, no.2 (1981): 115-34.
} 
The Wellington divorce sample shows that couples who divorced had far fewer children than the population as a whole (Table 7.2). Although the average family size for the population as a whole is based on completed family size, some people who divorced may have gone on to have more children with another partner. Average completed Pakeha family size changed during this period, from 3.4 children in 1916, dropping to 2.3 in 1936 and increasing again to 2.9 in $1945 .{ }^{8}$ One-third of couples in the Wellington case study had no children at the time they petitioned for divorce. Across the study period the median number of children per family at the time of divorce was one, and the mean was one and a half. Table 7.3 shows the mean number of children per couple, by petition year cohort.

Table 7.3

Mean Number of Children per Couple by Petition Year

\begin{tabular}{r|c}
\hline Petition Year & Mean Number of Children \\
\hline $\mathbf{1 8 9 8}-\mathbf{1 9 0 2}$ & 2.68 \\
$\mathbf{1 9 0 3}-\mathbf{1 9 0 7}$ & 2.00 \\
$\mathbf{1 9 0 8}-\mathbf{1 9 1 2}$ & 1.97 \\
$\mathbf{1 9 1 3}-\mathbf{1 9 1 7}$ & 1.58 \\
$\mathbf{1 9 1 8}-\mathbf{1 9 2 2}$ & 1.70 \\
$\mathbf{1 9 2 3}-\mathbf{1 9 2 7}$ & 1.56 \\
$\mathbf{1 9 2 8}-\mathbf{1 9 3 2}$ & 1.43 \\
$\mathbf{1 9 3 3}-\mathbf{1 9 3 7}$ & 1.39 \\
$\mathbf{1 9 3 8}-\mathbf{1 9 4 2}$ & 1.32 \\
$\mathbf{1 9 4 3}-\mathbf{1 9 4 7}$ & 1.21 \\
\hline TOTAL & $\mathbf{1 . 4 6}$ \\
\hline
\end{tabular}

Source: Wellington Divorce Database

There are two major possibilities to explain why couples who divorced had fewer children than those that remained married. Firstly, one spouse may have been unhappy about not having children. They wanted to end the relationship and to form another relationship to have children. The second, and more probable reason, is that couples with children had a greater incentive to stay married even if they were not happy. The financial cost of raising children was not insignificant, especially for wives. This reason alone may have been enough to stay in an unhappy marriage. In one case, a couple reunited, with the

\footnotetext{
${ }^{8}$ See Table 4.4 in Arunachalam Dharmalingam, Ian Pool and Janet Sceats. A Demographic History of the New Zealand Family From 1840: Tables, 11. Available at:

www.auckland.ac.nz/uoa/aup/nzfamily/nzfamily_home.cfm. See also, Pool et al. The New Zealand Family from 1840. A Demographic History. Auckland: 2007. For a study which covers the period when the Pakeha fertility rate declined most rapidly see, Elise F. Jones. 'Fertility Decline in Australia and New Zealand 1861-1936'. Population Index 37, no.4 (1971): 301-38.
} 
wife explaining that she took her husband back 'for the sake of the children' only later ending their marriage once the children had grown older. ${ }^{9}$ Moreover, increasingly during the first half of the twentieth century there was an emphasis on the psychological wellbeing of children and the adverse effect that divorce could have on children keeping marriages together longer than might have otherwise occurred. Table 7.4 shows that the more children a couple had, the longer their marriage lasted.

Table 7.4

Mean Length of Marriage in Years by Family Size

\begin{tabular}{c|c}
\hline Number of Children & Mean Length of Marriage in Years \\
\hline 0 & 10.15 \\
1 & 12.46 \\
2 & 14.95 \\
3 & 17.51 \\
4 & 21.67 \\
5 & 25.14 \\
6 & 25.04 \\
7 or more & 27.73 \\
\hline
\end{tabular}

Source: Wellington Divorce Database

Despite marriages with children being less likely to end in divorce, some did. For some marriages, the presence of children from previous relationships appears to have been one of the causes of tension leading to divorce. According to the divorce records, a small percentage of people seeking divorces had been previously widowed, or divorced before. ${ }^{10}$ The family loyalties of one spouse could cause conflict in the marriage. In 1945 Herbert P. told the court, 'I had an argument with my wife with regard to a step-daughter my wife wanted to bring to live at the home. That step-daughter was about to be confined. Her husband was overseas. I was not agreeable to the step-daughter coming to my home, on account of the probable trouble that might arise. As a result of that disagreement, my wife left'. ${ }^{11}$ If Herbert had been the father, rather than the step-father, of this young woman, he would have been far more likely to agree to have her in his home. A wife might resent the presence of her husband's children when that presumed that she would become their maternal caregiver. Twenty-one year old Phyllis N. petitioned for a divorce in 1936 on the ground of three years separation. She told the court,

\footnotetext{
${ }^{9} A v A \&$ E, AAOM/W3265/D3820/1931/ANZ-W.

${ }^{10}$ See Chapter Two for the marital status at marriage of those who divorced in the Wellington Supreme Court.

${ }^{11} P$ v $P$, AAOM/W3265/D2081/1945/ANZ-W.
} 
on my wedding day I ascertained that my husband had deceived me about certain matters. I found out after the marriage that he was a widower and had two children. I stayed with my husband on my wedding day and on the following day went along to where my sister was residing in Auckland...We had a full discussion with my sister, and we decided that we would separate. My husband was there. He said that well if I couldn't look after them (the children) I was no good to him. I said they were no good to me. ${ }^{12}$

Phyllis was unwilling to look after Reginald's children, no doubt partly because of his deceit, partly because of their short courtship and partly because of her age. While other men were not as clear-cut as Reginald when looking for a new wife, the need to have someone to look after children was a major consideration for most widowed and divorced men who had children.

Children also became directly involved in the divorce process itself. One of the major problems that wives had in proving cruelty was that often they had no witnesses in the privacy of the marital home except for their children who were often also victims of their father's violence. Sometimes children, particularly elder children, gave evidence against their fathers in court. For example, Jeremiah S. told the court in 1906, 'I have not torn my wife's blouse from her back - I have not torn her clothes in my life...I do not remember going into my wife's bedroom one night before the separation and striking my wife on the face'. ${ }^{13}$ Contradicting his father, fourteen-year-old John told the court, 'They were having a bit of a squabble \& all of a sudden he struck her in the face and he caught her by the blouse and in the struggle all the blouse was torn. I then went between my mother and father and took my mother upstairs. My father said it was all right'. ${ }^{14}$ John's nine-year-old sister Dorothy supported her brother stating, 'My father knocked my mother down. My mother was pouring a cup of tea out - He knocked her down \& he said he would knock her down every time she spoke in the house'. ${ }^{15}$ Despite the testimony of the two children the jury found that Jeremiah had not treated his wife with cruelty. The case was heard in camera as the judge, Robert Stout, ruled that there should be no publication of details of a case when children were giving evidence. ${ }^{16}$ Other than this protection, there is no

\footnotetext{
${ }^{12} R v R$, AAOM/W3265/D4840/1936/ANZ-W.

${ }^{13} S v S \& R, \mathrm{AAOM} / \mathrm{W} 3265 / \mathrm{D} 722 / 1906 / \mathrm{ANZ}-\mathrm{W}$.

${ }^{14}$ Ibid.

${ }^{15}$ Ibid.

16 'Divorce Suit'. Wanganui Herald, 28 May 1906.
} 
evidence of any concern being expressed about children having to give evidence against their fathers, or the impact that witnessing such violence had on children. ${ }^{17}$

The issue of custody also brought children into the divorce process. Other than the divorce itself, the most important power wielded by judges in divorce cases was in awarding the custody of the children. In the 1898 Divorce Act section 21 read:

In all undefended cases, where application is made to the Court to make the decree absolute, the Court may in its discretion give the wife the custody of one or more of the children; and may also do so in defended cases, on proof that the respondent has had notice of the intention of the petitioner, on the hearing of motion to make the decree absolute, to apply for the custody of one or more of the children. ${ }^{18}$

The assumption was husbands received custody of the children unless their wives challenged this position. In practice, however, the situation was not so clear cut. When orders for custody were made, and in many cases no custody order was made, mothers succeeded more often than fathers in gaining custody of their children. Colin James has argued that around the turn of the twentieth century there was a shift in legal practice in Australia from the presumption of the 'father-right' in awarding child custody to a bias towards mothers which he calls the 'maternal preference'. ${ }^{19}$ A similar shift occurred in New Zealand, although the shift to the 'maternal preference' occurred slightly earlier. However, when wives had committed adultery, particularly in the earlier part of the twentieth century, they found it difficult to gain custody or even access to their children.

The British legal background influenced the New Zealand situation. ${ }^{20}$ As a rule, when both husband and wife requested custody of the children, generally the petitioner, perceived as being the 'innocent' party, was granted custody. The only major difference between Britain and New Zealand was that the Supreme Court of New Zealand administered common law and equity concurrently. The equitable doctrines modified the law in favour of mothers. ${ }^{21}$ It was still difficult for adulterous women to gain access to or custody of their children, although it was not banned. The Guardianship of Infants Act

\footnotetext{
${ }^{17}$ For another example of a fourteen year old giving evidence about her father's violence see $O v O$, AAOM/W3265/D674/1905/ANZ-W.

${ }^{18}$ Divorce Act 1898 (62 VIC 1898 No. 42).

${ }^{19}$ Colin James. 'Winners and Losers: The Father Factor in Australian Child Custody Law in the $20^{\text {th }}$ Century’. Legal History 10 (2006): 207-38.

${ }^{20}$ For the British situation see Ann Sumner Holmes. "Fallen Mothers." Maternal Adultery and Child Custody in England, 1886 -1925', in Maternal Instincts. Visions of Motherhood and Sexuality in Britain, 1875-1925, eds. Claudia Nelson and Ann Sumner Holmes. Houndmills, UK: 1997, 39.

${ }^{21}$ Robson, 469.
} 
1926 made children's welfare 'the first and paramount consideration' when determining custody. ${ }^{22}$ When the couple shared custody of the children, mothers usually gained the custody of younger children, and girls, while fathers received custody of older children, and boys.

As shown in Table 7.5, wives received custody in the majority of cases. Judges made 610 custody orders in the Wellington divorce case sample. In 791 cases where there were children of the marriage, no custody order was made (although this does include cases where all the children were over 16 years old). Wives almost always succeeded in cases in which they were the petitioner, whereas husbands gained custody in just over half the cases in which they petitioned for divorce. This may reflect the fact that wives often petitioned on the ground of desertion, and therefore they gained custody without their husbands contesting the case, whereas many husbands used the ground of separation of three years or more when it had often been their behaviour that was responsible for the separation. In such circumstances, while they might be the petitioners, judges did not consider them the 'innocent' parties. The trend for mothers to be awarded custody in the majority of cases contributed to the problem of what is now known as the 'feminisation of poverty'. ${ }^{23}$

Table 7.5

The Awarding of Child Custody by Petitioner

\begin{tabular}{|c|c|c|c|c|}
\hline \multirow{2}{*}{ Petitioner } & \multicolumn{3}{|c|}{ Awarded Custody } & \multirow{2}{*}{ TOTAL } \\
\hline & Husband & Wife & Combined & \\
\hline Husband & $\begin{array}{c}120 \\
(57.14 \%)\end{array}$ & $\begin{array}{c}83 \\
(37.73 \%)\end{array}$ & $\begin{array}{c}17 \\
(7.73 \%)\end{array}$ & 220 \\
\hline Wife & $\begin{array}{c}13 \\
(3.33 \%) \\
\end{array}$ & $\begin{array}{c}370 \\
(94.87 \%) \\
\end{array}$ & $\begin{array}{c}7 \\
(1.79 \%) \\
\end{array}$ & 390 \\
\hline TOTAL & $\begin{array}{c}133 \\
(21.80 \%) \\
\end{array}$ & $\begin{array}{c}453 \\
(74.26 \%) \\
\end{array}$ & $\begin{array}{c}24 \\
(3.93 \%) \\
\end{array}$ & 610 \\
\hline
\end{tabular}

Source: Wellington Divorce Database

The importance placed on women raising their daughters and men raising their sons is demonstrated in a 1911 Dunedin case where a wife petitioned for custody of her three children (one boy aged ten, and two girls aged seven and five) after she divorced her

\footnotetext{
${ }^{22}$ Ibid.

${ }^{23}$ James, 210.
} 
husband for adultery. The children lived with their father at the time. Justice Williams found:

The two girls have ceased to be little children, and are growing up into womanhood. A man cannot look after them properly. It is right that there should be some woman to who they can talk, and in whom they can confide, and who will advise and direct them. If they are left with their father, the woman who looks after them will be a housekeeper - a hired servant...In such circumstances, where the mother is innocent of any matrimonial offence, it is obvious that she is the natural person to take charge of her female children....As to the boy, it is different. His father is very much attached to him, and he to his father. As growing girls want a woman to look after them, so growing boys are better in charge of a man. There is nothing to show that there has been a continuance of immorality on the part of the respondent, not to suggest that the fact of his previous fault will affect the morals of the boy... There must be the fullest provision for access to the children both for the petitioner and the respondent. ${ }^{24}$

An adulterous wife did not receive the same consideration by the courts, especially in the early twentieth century. Colin James detected a similar pattern in Australia, whereby the court 'assumed that it would rarely be in a child's interest to be placed in the care of a mother who was an adulterous woman... When the father was guilty of adultery, many instances of "convenience and advantage to the children" could serve to prevent them being taken from his care'. ${ }^{25}$ Public opinion considered that boys and girls could be influenced by parental behaviour in different ways. This reflected the court decision which deemed it was far worse for girls to live with a mother who had committed adultery than for boys to live with a formerly adulterous father. This is another indicator that the effects of the sexual double standard persisted.

In 1923 Justice Adams expressed this judicial attitude to adulterous wives when a Christchurch mother applied to the court for custody of her three children. By the time of her application she had married the co-respondent in her divorce suit. The judge outlined the general rule of the court which was to consider, first, the welfare of the children, and, secondly, the interests of the innocent party. He found,

If the custody of the children was given to [the mother] she would no doubt be their guardian in name, but in fact they would be in the custody of the corespondent, who, when the petitioner was risking his life in the service of his country, crept into his house, seduced his wife from her allegiance, and brought shame and domestic ruin upon him. To suffer such a consummation would be to put a premium upon treachery and immorality, bring additional

\footnotetext{
${ }^{24}$ Morton v Morton, [1911], NZLR, 78-79.

${ }^{25}$ James, 216.
} 
and intolerable shame upon the innocent victim, and to condemn the children to be the continual witnesses of the triumph of evil. ${ }^{26}$

While there was no continuing 'immorality' on the part of the mother, she was unable to gain custody or even access to her children because it was assumed that her new husband had not only stolen the wife but would usurp the role of their father teaching the children that sin might be rewarded rather than punished.

Some judges expressed a more moderate attitude mixing punishment with some degree of compassion to adulterous mothers and their children. In 1928 a divorced mother petitioned for custody of her two daughters. Justice Ostler found that the children had been 'deserted by the respondent and left in the custody of the petitioner' but had been 'well cared for. Petitioner has ample means to provide for them, and female relatives who can take charge of them'. ${ }^{27}$ The husband received custody but the respondent gained 'limited access' to her children. In the judge's view,

Although she was found guilty of adultery on her own admission, there is no evidence that she was or is living a loose life. The children are both girls, and both very young. Though the respondent gave way to temptation, she still remains their mother, and bears towards them a mother's love. She is now living a reputable life, and it would be depriving the children of a priceless influence in their lives to cut them off from any intercourse with their mother.

She was granted two hours access every Saturday afternoon during their school terms, and the judge further allowed 'if the conduct of the respondent warrants it and it is found to the advantage of the children to spend part of their holidays with their mother, such an order may be made hereafter'. ${ }^{28}$ Still punished as the guilty party, the woman did gain some recognition that her maternal status deserved some consideration.

This trend towards treating adulterous mothers less harshly continued, particularly during and after World War II. Women divorced on the ground of adultery could retain full custody of their children, albeit with their husband's consent. ${ }^{29}$ Moreover, the records relating to child custody included in the divorce files often relate only to the arrangements made at the time of the divorce and not subsequently, which could differ from the original

\footnotetext{
${ }^{26}$ Van Der Veen v Van Der Veen, [1923], NZLR, 796.

${ }^{27}$ Bolton v Bolton, [1928], NZLR, 475.

${ }^{28}$ Ibid.

${ }^{29}$ For example see, $M v M \& W$, AAOM/W3265/D153/1940/ANZ-W; $W v W \& S$, AAOM/W3265/D805/ 1942/ANZ-W; $H \vee H$, AAOM/W3265/D1141/1943/ANZ-W; $D v D \& M$, AAOM/W3265/D1307/1944/ ANZ-W; $E v E \& W$, AAOM/W3265/D2037/1945/ANZ-W; $C v C \& S$, AAOM/W3265/D2429/1946/ANZ$\mathrm{W} ; J v J \& J$, AAOM/W3265/D349/1947/ANZ-W.
} 
agreement. Women denied custody of their children often regained it if their former husbands had no one to look after their children while they worked, or put their children into orphanages. ${ }^{30}$ In 1933 one wife told the court, 'my husband had the custody of the boy and I had the custody of the girl. I have not lived with my husband since the date of the separation. The boy was put into a Home at Nelson and then transferred to a home at Lower Hutt. My husband has not seen him for two and a half years or more. He has not paid anything for maintenance for two and a half years'. ${ }^{31}$ Women would often track down their children in homes and, as soon as they were able to financially support them, would reacquire custody of them. It was not only men who relinquished their duties to their children. In 1944 Edward M. told the court, 'There are two children. One lives with me and the other is boarding with friends at Christchurch. We lived at Wellington until February 1944 and my wife was in business of her own then and she said she wouldn't live with me any longer. We got on quite well until she said she couldn't be bothered with the children as they were getting on her nerves'. ${ }^{32}$ Just as some men and women had little desire to be a husband or a wife, some had equally little desire to be a father or mother, although such individuals were far rarer than those not wanting to be a spouse.

Sometimes neither spouse could care for the children, and they turned to external agencies. In large part this was determined by the financial situation of the divorcing couple, but also the desire (or lack of) of some individuals to be parents. In December 1947 Eric J. told the court, 'About the month of August 1946 my wife left my home and took with her the two eldest children. She went to Lower Hutt to her sister's place. I put the baby in the Home of Compassion. From there it has since been adopted. ${ }^{33}$ If faced with a choice, parents usually retained custody of older children (perhaps as a result of a stronger bond with them or because of the greater difficulties of earning a living with an infant in the household) and arranged for the adoption of babies who were, of course, more likely to be placed with adoptive parents rather than ending up in an orphanage. ${ }^{34}$

\footnotetext{
${ }^{30}$ For example see, $L v L$, AAOM/W3265/D17/1940/ANZ-W.

${ }^{31} M v M$, AAOM/W3265/D4204/1933/ANZ-W.

${ }^{32} M v M$, AAOM/W3265/D1467/1944/ANZ-W.

${ }^{33} J v J \& J$, AAOM/W3265/D349/1947/ANZ-W.

${ }^{34}$ For example see $B v B$, AAOM/W3265/D1839/1920/ANZ-W; $J v J \& J$, AAOM/W3265/D349/1947/ ANZ-W. While most adoptions in the post-World War II era involved babies born to unmarried mothers, between 20 to 30 per cent of adoptions until 1960 involved babies born within marriages. For further details of this, and the stranger adoption process in general see, Anne Else. A Question of Adoption. Closed Stranger Adoption in New Zealand 1944-1974. Wellington: 1991.
} 
For couples who could afford it, boarding school offered a way to take care of their children, especially boys. In 1929 Andrew M. petitioned for divorce on the ground of separation of three years or more. The couple had a ten year old son. In court he said, 'my wife has consented to my having the custody of the child. Under the deed my wife was to have the custody of the child until he was 10 years old: but she found that she could not look after him, not having a home of her own and she decided to reduce the amount that I was to allow her on condition that I sent him to Scots College'. ${ }^{35}$ If a father could afford to pay for a boarding school, it provided an opportunity for the mother to find paid work, and both parents were able to share custody during the school holidays.

Other interested family members could become involved in custody disputes. In 1923 Wilfred S. petitioned for divorce from his wife Mary on the ground of adultery and was successful. There was, however, a dispute over the custody of their baby daughter Mary. The couple married in September 1922, a month before the birth of their daughter. At the time of the marriage the groom was 21 and the bride was 16 . Wilfred had requested the custody of Mary, but his wife, who admitted committing adultery requested that custody of their daughter be given to her mother, the child's grandmother. She claimed, 'the petitioner is deficient morally, mentally and physically and by reason of such disabilities is unfitted for the training and upbringing of children'. Since she also admitted that she was 'unfitted for the training and upbringing of the said child', she asked that the grandmother continue to care for the baby as she had done since Mary's birth. ${ }^{36}$ The court granted the grandmother permanent custody. The fact that this mother placed the welfare of her daughter over any need that she may have had to 'win' a custody dispute in court showed the degree of concern some parents had for the welfare of their children, or possibly her claims were an effort to convince the judge that she had such feelings in order to maintain access to her daughter.

Sometimes husbands employed a similar tactic planning to have their mother (or sometimes a sister) care for the children on a daily basis, but this plan did not always succeed. ${ }^{37}$ In a 1951 case where a husband had divorced his wife on the ground of failure

\footnotetext{
${ }^{35} M v M$, AAOM/W3265/D3440/1929/ANZ-W.

${ }^{36} S v S \& M$, AAOM/W3265/D2501/1923/ANZ-W.

${ }^{37}$ For example, $B \vee B$, AAOM/W3265/D353/1940/ANZ-W; $S v S \& J$, AAOM/W3265/D677/1942/ANZW.
} 
to comply with a restitution of conjugal rights. Justice Adams awarded custody of the two young daughters to the mother. He said,

If custody were given to the father, the children would be for the most part under the care of his parents, aged respectively sixty-five and sixty-four, with whom the husband was at variance throughout the consortium, and who have never yet seen either of the children. The wife, on the other hand, has always had the care of these children, and is a comparatively young person, likely to survive the husband's parents. Her custody is likely to endure throughout the infancy of the children, whereas the care and attention which might be given by the husband's parents is likely to end while these girls are still comparatively young. ${ }^{38}$

By 1951, as illustrated in this case, the ever growing emphasis on the well-being of the children, combined with a decreasing drive to punish the 'guilty' parent influenced decisions of custody for what the court deemed to be the best interests of the children. ${ }^{39}$

Some parents chose to allow their children to decide which parent he or she wished to live with. For example, Alan S. who returned to New Zealand in August 1943, after being in a prisoner of war camp in Italy for 17 months, suspected that his wife had committed adultery in his absence. The couple had two sons aged 13 and 14. He told the court in 1944, 'It was decided that I should leave home and take out a separation order. My wife decided that. I said I would not do that unless the boys after being told the circumstances agreed that I ought to go. The boys' decision was made known in the presence of my wife and their decision was that they would stay with me'. ${ }^{40}$ The boys were personally aware that their mother had committed adultery and helped their father obtain evidence against their mother.

While the existence of children made spouses less likely to seek divorce, it did not prevent divorce. Marriages that were the result of unplanned pregnancies were more likely to end in divorce suggesting the presence of children alone, was not enough to sustain a marriage. The presence of step-children sometimes created strains that imperilled a marriage. Divorce, in turn, exerted a major impact on the lives of children, which might include having to give evidence against one of their parents in court. Following this, came battles over custody, reflecting changes in beliefs about fathers' and

\footnotetext{
${ }^{38}$ Norton $v$ Norton, [1951], NZLR, 683.

${ }^{39}$ Mary Ann Mason. From Father's Property to Children's Rights: A History of Child Custody. New York: 1994.

${ }^{40} S v S \& M$, AAOM/W3265/D1209/1943/ANZ-W.
} 
mothers' rights and children's interests. In these patterns New Zealand resembled changes occurring elsewhere, as marital bonds loosened and children's relationships to their parents adapted to the growth in divorce and a diversifying range of family arrangements. 


\section{Chapter Eight}

\section{The Changing Landscape of Marriage and Sexuality}

With the introduction, in 1920, of the ground of mutual separation of three years or more, there was a relatively non-adversarial way to obtain a divorce in New Zealand. Divorce on this ground did not require the disclosure of intimate details of the marriage - sexual or otherwise - in court. Essentially all that was required was for the petitioner and a friend to appear in court and both swear the petitioner had been living apart from their spouse for more than three years. The existence of this ground reduced the degree of public exposure and scandal associated with divorce at the time, and allowed what Anna Clark has described as 'twilight moments' to remain concealed from public scrutiny. ${ }^{1}$ Despite this possibility, however, some spouses still chose to take the route that revealed intimate issues such as adultery in public. The divorce court provided a public arena where husbands and wives contested the relationship between marriage and sexuality providing insights into expectations about sexual behaviour in marriage. The complaints recorded in the divorce case files highlight the behaviours which diverged from sexual and gender norms. Moreover, some of the more detailed testimonies capture the intimacy, which were part of these sexual encounters, and the geographical locations of these acts which contributed to the degree of intimacy which the court processes brought under public scrutiny. As Matt Cook has explained, the legal framework 'was one of the ways in which people came to know about the "rights" and "wrongs" of sex" and it was also 'the primary means through which the state attempted to regulate "morality" and people's supposedly private lives'. ${ }^{2}$ This chapter will explore those divorce cases that involved exposure in order to study some of the forms of sexual practice in New Zealand and also to shed further light on the motives and circumstances of those seeking divorce.

Anna Clark used the twilight moment 'as a metaphor for those sexual practices and desires that societies prohibit by law or custom but that people pursue anyhow, whether in

\footnotetext{
${ }^{1}$ Anna Clark. 'Twilight Moments'. JHS 14, nos.1/2 (2005): 140; also see Anna Clark. Desire. A History of European Sexuality. New York: 2008, 123-41.

2 Matt Cook. 'Law', in The Modern History of Sexuality, eds. H.G. Cocks and Matt Houlbrook. Houndmills: 2006, 64.
} 
secret or as an open secret'. ${ }^{3}$ This metaphor referred to 'sexual relationships, desires, and practices that were neither celebrated...nor utterly forbidden, deviant, or abject' ${ }^{4}$ Divorce trials transformed these intimate, sometimes romantic encounters into legalistic representations. Ivy M's account of accepting money and gifts from her lover, drinking wine, and having 'sexual intercourse with him on several occasions' exemplifies such moments. She described her relationship with Mr J., which resulted in her appearance in court in $1943 .^{5}$ The presence of these 'moments' heard in evidence simultaneously labelled these sexual practices as unacceptable even as they also served to normalize them by making their occurrence visible. Although Clark argues that ' $[\mathrm{t}]$ he concept of twilight moments seems most useful to the period before the twentieth century, when sexological and sexualized commercial discourses gained wider circulation, exposing secret desires, fantasies, and practices to the harsh glare of daylight, ${ }^{, 6}$ her concept of 'twilight moments' remains a useful tool for discussing the way sexuality became visible through divorce cases in the first half of the twentieth century.

Building upon Anna Clark's metaphor this chapter explores the ways in which divorce cases exposed details of married couples' sexual lives, and particularly adultery, 'to the light of day what had long been concealed in darkness'. ${ }^{7}$ By the time testimony revealed these 'twilight moments' in court, they had clearly moved from the twilight into the broad light of day. Thus divorce court proceedings served as a form of punishment for the pleasures of these secret, illicit encounters brought before the disapproving gaze of judges, the public, the press and discussed in the chatter of gossip. The courts thus functioned like a public stage where people risked the punishment of shame, ridicule, becoming the butt of gossip and damage to personal reputation in order to obtain a legal divorce. This might allow them to remarry and rejoin 'respectable' society, demonstrating the value attached to being legally married during this period. Spouses convinced of their own innocence and their partners' guilt seized the opportunity to break the silence about their errant spouses' guilty secrets to punish their transgressions in the court of public opinion as well as the divorce court. ${ }^{8}$

\footnotetext{
${ }^{3}$ Clark, 'Twilight Moments', 140.

${ }^{4}$ Ibid., 149.

${ }^{5} M v M \& J$, AAOM/W3265/D1315/1944/ANZ-W.

${ }^{6}$ Clark, 'Twilight Moments', 159.

${ }^{7}$ Ibid., 140.

${ }^{8}$ Judges did have the power to hear cases in chambers if requested to do so by either the petitioner or respondent, but in practice very few litigants requested that this occur.
} 
While there were an increasing number of fora for the discussion of sexuality during this period, the discussion was often abstract. There was a big difference between reading about sex in marriage guides such as Marie Stopes' Married Love, and having one's own intimate details made public especially when these details showed moral failings on the part of at least one, if not both spouses. As Robert Griswold has argued, 'By its nature, adultery was a crime of secrecy, but it was also a crime with powerful public reverberations once legal accusations were lodged'. ${ }^{9}$ The public exposure created by the judicial process and intensified by the coverage of divorce cases in newspapers was seen as a further 'punishment' for those who had violated their marriage vows as has been explored in Chapter Five.

Although adultery and extra-marital intercourse were not the only acts of sexuality discussed in the divorce cases, the need to establish matrimonial fault shaped the ways in which sexual relations and behaviours were discussed. Griswold has shown that in nineteenth-century America, divorce trials offered one of the few occasions

when an everyday farmer, blacksmith, or housewife actually offered his or her moral judgments about manhood and womanhood to a representative of the state. Back-fence chatter was one thing, testimony under oath quite another. ${ }^{10}$

The same could be said for New Zealand where courts, tabloids, and the daily newspapers amplified the voice of gossip, the public scold and the moralist. As was shown in Chapter Four, the vast majority of New Zealanders who divorced during the first half of the twentieth century were working class which reinforces Griswold's point: divorce cases give insights into the views of working people on sexual behaviour. Through discussions about extra-marital sex, complaints about limited or no marital sex, accusations of wives' sexual insatiability, complaints about husbands labelling their wives as prostitutes, and detailed accounts of couples caught in the act of having sexual intercourse, the community clarified gender and sexual norms by making clear what was and was not appropriate marital behaviour while making it apparent how often the inappropriate or the immoral occurred. ${ }^{11}$

\footnotetext{
${ }^{9}$ Robert L. Griswold. 'Divorce and the Legal Redefinition of Victorian Manhood', in Meanings for Manhood. Constructions of Masculinity in Victorian America, eds. Mark C. Carnes and Clyde Griffen Chicago: 1990, 109.

${ }^{10}$ Ibid., 99.

${ }^{11}$ Ibid.
} 
Figure 8.1

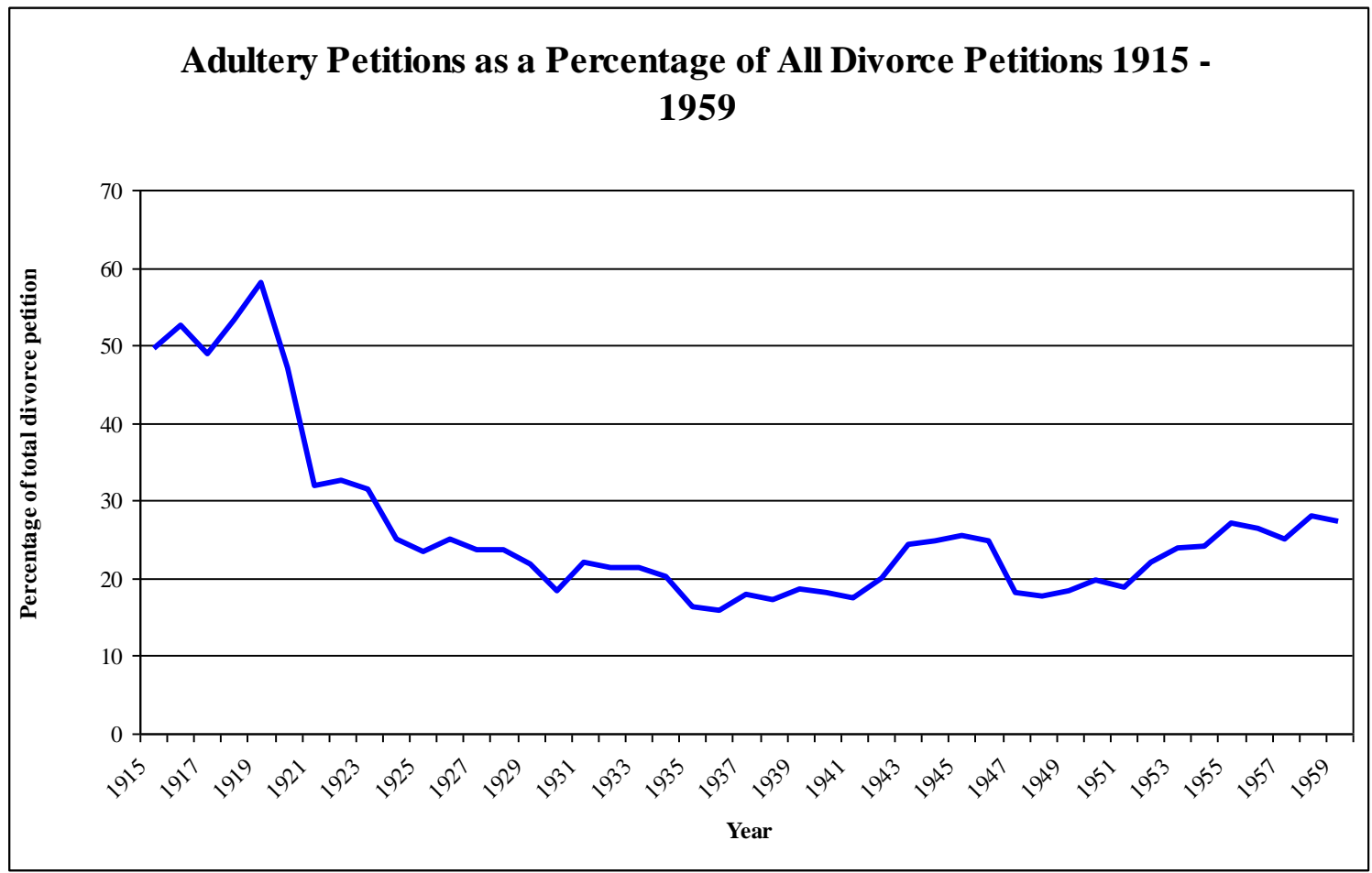

Source: Statistics of New Zealand (data before 1921), Report on Justice Statistics (data from 1921).

Bronwyn Dalley has argued that "files labelled "sexuality" or "sexual behaviour" aren't found in abundance', in archival institutions and that particularly for the period before the mid-twentieth century 'material relating to sexuality is more likely to be embedded in documents on other subjects'. ${ }^{12}$ Divorce files are an example of such documents. Some divorce files provide a wealth of information and a detailed, if not a full picture, of the unravelling of the marriage. Other files contain extremely limited information. Lawyers prepared the legal documents contained in the file (with the exception of the marriage certificate), reshaping the petitioner's statement into a legal argument that supported at least one of the grounds for divorce. The documents are formal, rather than conveying emotion or intimacy. Stephen Robertson has suggested that one of the limitations of legal files is that because sexual behaviour is only discussed in terms of the law, accounts offered by defendants and witnesses have been distorted. He goes on to explain, 'in particular, court records usually deal with sexual acts, shorn of the participants' motives and understandings of those acts and without reference to their lives beyond the moment

${ }^{12}$ Bronwyn Dalley. 'Creeping in Sideways: Reading Sexuality in the Archives'. Archifacts (2001): 35. 
in which the act took place'. ${ }^{13}$ Despite these problems, some of the feelings and thoughts associated with the loosening of the marriage were expressed in the letters and the court transcripts which sometimes are included in the file.

Figure 8.2

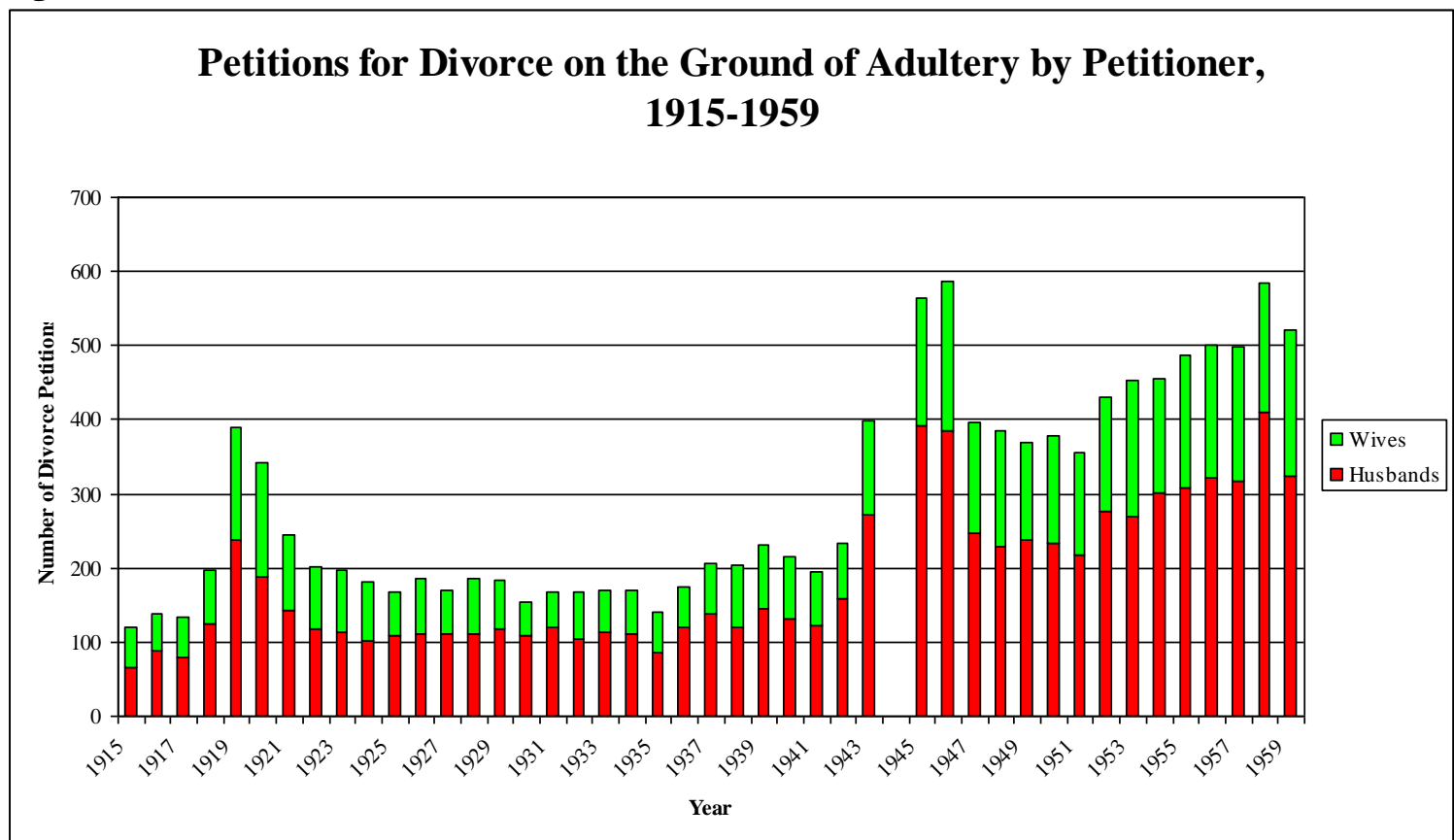

Source: Statistics of New Zealand (data before 1921), Report on Justice Statistics (data from 1921). No data was available for 1944 due to a reduction in the recording of statistics during World War II.

Not surprisingly, divorce cases involving accusations of adultery were the most likely to include a discussion of sexual relations. The petitioner was required to prove an act of adultery had taken place and that the petitioner had not condoned the adultery. ${ }^{14}$ The focus may have been on the extra-marital relationship, but the marital relationship also came in for scrutiny. While a single act of adultery was all that was legally required to petition for divorce, most cases involved multiple instances of adultery, either with one individual where a marriage-like union had been formed or with multiple partners. Men more often petitioned for divorce on the ground of adultery than women - see Figure 8.2 - but some men forgave their wives for one 'omission' and only petitioned for divorce once they realised that their wives had no intention of remaining monogamous. In 1947, for example, Joseph R. stated in court,

\footnotetext{
${ }^{13}$ Stephen Robertson. 'What's Law Got to Do with It? Legal Records and Sexual Histories'. JHS 14, nos.1/2 (2005): 162.

${ }^{14}$ Despite women being more likely to petition for divorce between 1898 and 1940, men made up the majority of petitioners using adultery as a ground for divorce during this period suggesting the endurance, if not in law, then in practice and popular attitudes, of the double standard.
} 
I came home one night and found [my wife] in a state of undress in the bedroom; there was a man in the room who was just putting his shoes on. I forgave her that incident. Things were all right for a while; I forgave her that. She then kept company with a US Marine. I made endeavours to prevent her doing so, but she did not comply with my demands. ${ }^{15}$

This is not to suggest husbands were as forgiving of adultery as wives, or in fact that most husbands or wives were forgiving of adultery, but that there were occasions when a spouse was prepared to make concessions in order to try to maintain the marriage. Such information was then presented in court as evidence of how tolerant and forgiving the petitioners had been, and they were only petitioning for a divorce as the respondent had persistently violated the marital vows. Another serviceman, who was not as tolerant as Joseph R., refused to forgive his wife for an affair she had while he was in a prisoner of war camp. He told the court, 'She asked me if I would forgive her and come back to the house. I said it was not possible to do that because of what had taken place with $\mathrm{M}[\ldots]$....My wife said she could not see why I would not forgive her as other women had committed adultery and been forgiven'. ${ }^{16}$ His wife's reaction suggests that many other servicemen had forgiven their wives for committing adultery while they were away (and of course many servicemen also committed adultery, but it was more difficult for their wives to gain any specific knowledge of their infidelity overseas). ${ }^{17}$

A case which illustrated a 'twilight moment' being dragged into the harsh light of day and public exposure was heard by the court in 1919. Mr W., then living apart from his wife had become suspicious of her behaviour. Mr W. decided to watch his wife's house. After he saw a man enter her home and the lights went out, he waited several minutes, and then also went inside. He found his wife and $\mathrm{Mr} \mathrm{H}$. on the sofa together. He reported that:

They were having connection. I pulled $\mathrm{H}[\ldots . .$.$] off -\mathrm{I}$ do not know the exact words I called him - I was a bit wild. His trousers were hanging down below his knees and Mrs W[...] had one leg out of her pyjamas and her person was exposed. I picked $\mathrm{H}[\ldots]$ up and made him walk out of the house with me and down the right-of-way. I thought I would want a witness. H[...] had to hold his trousers to keep them up - they were right down to his knees. I wanted someone to see him in that condition. I saw the man who keeps the sweetshop standing by his door and I called him but at first he would not come. While he was coming Mr R[...] came along. I stopped Mr R[...] and asked him to have a look at $\mathrm{H}[\ldots]$ '.. 's condition. I said that I had caught $\mathrm{H}[\ldots]$ on top of my wife at the house and that I had pulled him off. I said, "What would you do with a beast like this?" He said "I would give him a damn good hiding". I

\footnotetext{
${ }^{15} R v R \& M$, AAOM/W3265/D2393/1946/ANZ-W.

${ }^{16} S v S \& M$, AAOM/W3265/D1209/1943/ANZ-W.

${ }^{17}$ Chapter Three explores this issue in more detail.
} 
said, "He's too old to hit - if he was a young man I would knock his head off"'. 18

Clearly, prior to the formal divorce case, $\mathrm{Mr} \mathrm{H}$. experienced a very full and complete public exposure. Even after he was allowed to pull his trousers up properly, $\mathrm{Mr} \mathrm{W}$. went to $\mathrm{Mr} \mathrm{H}^{\prime} . \mathrm{s}$ home and told his wife what he had seen. So by the time of the actual court case, $\mathrm{Mr} \mathrm{H}$. had experienced the worst of his public exposure by being dragged into the street half naked, and the court case was a more mild form of the original exposé in which the angry husband had a further chance to humiliate his rival.

The sexual double standard slowly began to be challenged in the early twentieth century. Ann Sumner Holmes has credited this change with the growing legal position of women, as well as the influence of Havelock Ellis who challenged the belief that women were naturally chaste. ${ }^{19}$ She believes, however, that the removal of the double standard from English divorce law in 1923 was a conservative act, with the main concern being husbands infecting their wives with venereal disease, and the belief that husbands' adultery contributed to the 'prostitution problem'. ${ }^{20}$ New Zealand women, who had had the double standard removed from the divorce law in 1898, were also in practice, increasingly less likely to accept their husbands committing adultery. In 1943 Joyce L. petitioned for divorce from her husband Gordon on the ground of separation of three years or more. She told the court, 'In January 1940 we were living at a flat in Christchurch. My husband was 12 years older than I was. In January I found out he was going out with another woman and I complained about it. We quarrelled and he told me if I didn't like it I could go'. ${ }^{21}$ This case also illustrates that petitioners did not always use the ground of adultery when petitioning for divorce, even if they were entitled to. Another wife during World War II was not prepared to tolerate her husband's adultery. In 1944 Lola W. told the court, 'On Anzac Day my husband brought Enid S [...] to my house and he said he wanted me to meet his future wife. From that stage I was not happy with my husband. I remember Saturday $20^{\text {th }}$ May. I did not go home that night as my husband was having a party in the house... The next morning I went to my house and I found him in

\footnotetext{
${ }^{18} W v W \& H$, AAOM/W3265/D1707/1919/ANZ-W.

${ }^{19}$ Ann Sumner Holmes. 'The Double Standard in the English Divorce Laws, 1857-1923'. Law \& Social Inquiry 20, no.2 (1995): 610.

${ }^{20}$ Holmes, 619. For a study of the influence of venereal disease on divorce in nineteenth-century England see, Gail Savage. "“The Wilful Communication of a Loathsome Disease": Marital Conflict and Venereal Disease in Victorian England'. VS 43, no.1 (1990): 35-54.

${ }^{21} L v L$, AAOM/W3265/D937/1943/ANZ-W.
} 
bed with Edith $\mathrm{S}[\ldots]]^{22}$ These cases provide examples of women's growing ability and willingness to challenge their husbands' extramarital relationships, suggesting both a shift in the power relations within marriage and also changing views about male sexuality and the assumption that wives had to tolerate their husbands having extra-marital relationships.

While the files did not contain descriptions of men as being 'oversexed', occasionally such descriptions appeared for women. One adultery case from 1921, which was defended, involved numerous accusations by the petitioner, William B. about his wife's sexual behaviour. In copious letters to his wife, he listed the names of many men he believed his wife had sex with, both prior to and during their marriage. William B. used a wide variety of phrases and claims to emphasize his disapproval of her behaviour. On 30 April 1921 he wrote,

I find out that you have misbehaved at every place you have worked, Monty's, Birdling's, Von's, Dan's, and Cameron's. I expect you carried on with Birdling before his wife died, and I expect you slept a good few nights with Alf your cousin. You will surely stop soon. I hear you have been at it since fifteen and now over 40 in disgrace, in the family way. You are about the hottest woman for men I ever heard of. It is a wonder I did not catch that disease off you and am lucky to escape so easy.

In another letter he called her a 'slut', and in another he described her as, 'the hottest thing ever anyone here heard of'. He discussed her behaviour with other members of the community and informed her that he and a friend,

both agreed you were a sexual maniac...They say here that if I had scratched the town for the lowest woman on the street I would not have got one as bad as you...I was telling one of your lady friends all about the men you carried on with before and after marriage. She said all you wanted was a farm with a Bull, you would keep that busy all the time. Fancy at forty, just as hot as you were at sixteen. ${ }^{23}$

His wife, Annie B., the respondent, submitted these letters to the court, rather than the petitioner. Presumably she did so to illustrate what an irrational person he was, and to complain about the allegations that he was making about her, as there was certainly a difference between being accused of having an affair with one person, and being accused of sleeping with every man she had ever had contact with. Truth's extensive coverage did not mention these letters indicating the judge and jury may have read them, but they were

\footnotetext{
${ }^{22} W v W$, AAOM/W3265/D1545/1944/ANZ-W.

${ }^{23} B$ v B \& $C$, AAOM/W3265/D2135/1921/ANZ-W.
} 
not read aloud in court. ${ }^{24}$ William B. succeeded in his petition for divorce and the corespondent was ordered to pay him damages of $£ 750$.

Divorce cases also made visible feelings of sexual jealousy and concerns about wives' sexual behaviour, even when no evidence could be produced to prove those suspicions. Jealous husbands accused their wives of promiscuity. Wives who petitioned for divorce on the ground of cruelty, in turn sometimes complained about their husbands calling them prostitutes or other similar terms. ${ }^{25}$ In fact, this was the single most common complaint made by wives using mental cruelty as a ground for divorce. One wife claimed her husband called,

me all the filthy names that he can think of and says I am everything that is bad. It is not very nice. He calls me a bastard, a prostitute, everything he can think of. He makes allegations against my morality with any man in the place, young or old. ${ }^{26}$

She received a divorce on the ground of her husband's cruelty and drunkenness. Other husbands also took a similar line to William B., accusing their wives of sexual infidelity. When making claims of adultery some husbands maintained their wife was living as a prostitute. For example, Herbert C. said, 'I have been unable to find out where she has been living lately. She used to live in a place in Vivian Street - the Lancaster Boardinghouse. It is practically a brothel - a house of ill-fame'.27 Although he gained a divorce on the ground of adultery, there was no evidence of his wife's prostitution.

In cases where women had been arrested for prostitution related crimes, however, husbands found it easy to divorce them. For example, William W. in his petition in May 1905:

the said Minnie $\mathrm{W}[\ldots]$ has lived a loose and immoral life and has continuously frequented, lived at and kept houses of ill-fame, and on divers occasions between the said month of January 1900 and the present time at

\footnotetext{
24 'Alleged Love in a Cowshed', NZT, 27 August 1921; 'Love in a Cowshed'. NZT, 24 September 1921.

${ }^{25}$ In 1898 Parliament passed the Slander of Women Act which meant that those who falsely accused women of 'unchastity' or adultery could be taken to court. There is no reference in the divorce files to any wives taking their husbands or anyone else to court on this ground. What this does show is the severe consequences for women of having a 'reputation'. The fact that the law did not also apply to men suggests that they did not suffer the same social consequences from being known as unchaste or promiscuous. See, Slander of Women Act 1898 (62 VIC 1898 No. 16). Robert Griswold has found in his study of American divorce cases that judges were prepared to accept that falsely accusing a wife of adultery was mental cruelty and was grounds for a divorce. See, Robert Griswold. 'Law, Sex, Cruelty, and Divorce in Victorian America, 1840-1900'. American Quarterly 38, no.5 (1986): 721-45.

${ }^{26} W v W$, AAOM/W3265/D57/1947/ANZ-W.

${ }^{27} C v C$, AAOM/W3265/D1303/1915/ANZ-W.
} 
Wellington aforesaid and elsewhere the said Minnie $\mathrm{W}[\ldots]$ has committed adultery with persons whose names are to your petitioner unknown. ${ }^{28}$

The file also included a list of Minnie W's seventeen convictions for drunkenness, assault, vagrancy and disorderly conduct between July 1899 and June 1905 (the couple had been married in October 1896). In contrast to these claims made by husbands, wives almost never accused their husbands in the divorce files of frequenting brothels.

Since adulterous acts were not usually witnessed, signed confessions, evidence of living in the same house or hotel, or the occurrence of a sexually transmitted disease or pregnancy supplied the evidence to support accusations of promiscuity and adultery. Those that were 'caught in the act' had to endure having the intimate details of their sex lives repeated in court, often in lengthy statements by their spouse. Some of these encounters, relayed in evidence, took place in private homes where the petitioner and their partner may have been particularly surprised about being caught, while other encounters occurred in more public areas. Most couples observed having intercourse were in a private home where they believed they were unlikely to be seen together. In most cases where such acts were observed, the husband and wife were separated and living in different homes, but sometimes the husband or wife brought a third party into the marital home. In 1893, Mrs O. had become ill and her husband had brought Mrs E. to their home to nurse his wife and help run the household. Twelve years later when Mrs O. petitioned for divorce, she explained how she discovered that her husband was having a sexual relationship with Mrs E. The case was being heard in chambers on the order of the judge, and Mrs O. told the judge and jury:

Mrs E[...] stayed in the house at the time. They used to come into my bedroom at nights \& pass their hands over my eyes to see if I was asleep \& I used to get suspicious, \& they used to lock the door in the kitchen $\&$ one night I got up \& found the door unlocked \& I caught them on the rug in front of the fire. They were misbehaving themselves. ${ }^{29}$

Other husbands sent their wives and children on holiday, and moved another woman into the home during the absence of their family. ${ }^{30}$ Women who had sexual relationships in

\footnotetext{
${ }^{28} W v W$, AAOM/W3265/D654/1905/ANZ-W.

${ }^{29} O \vee O$, AAOM/W3265/D674/1905/ANZ-W.

${ }^{30}$ For example, Mary W. told that court, 'In October 1938 my husband sent me for a holiday at Palmerston North from Titahi Bay. When I returned I found that my husband had been living with another woman' $-W$ $v W$, AAOM/W3265/D5517/1939/ANZ-W.
} 
the marital home usually did so with boarders. ${ }^{31}$ The difference being that men brought someone into the home with whom they already had some sort of romantic or sexual liaison, whereas women developed relationships with men who had entered their home as a stranger or mere acquaintance.

By the 1940s cars afforded adulterous couples a greater degree of privacy, but could become an easy target for surveillance by a suspicious spouse. In $1941 \mathrm{Mr}$ S. and his daughter used a taxi to follow their wife and mother, who was in a private car with a $\mathrm{Mr}$ H. After the car stopped, Mr S. and his daughter got out of the taxi, and approached the car. Mr S. told the court:

The window was open and I extended my arm fully into the car with a lighted match... They were both in the back seat and my wife had her dress up above her knees and $\mathrm{H}[\ldots]$ had a fire uniform on with the tunic open and his trousers undone. I struck another match and said "Hello H[...] I have caught you again have I?" and he said "all right, all right." I said, "You have got your trousers undone too" and he said "all right, all right" again and commenced climbing over the two front seats (bucket seats) like a boy and drove away without putting the lights on. ${ }^{32}$

Other spouses merely watched what occurred and then later gave evidence in court. This was especially easy when adulterous couples used public spaces such as parks. Mrs F. told the court in 1943 that she had been following her husband and his girlfriend through the streets of Christchurch and into Hagley Park. She said: 'I went to within a few yards from them. They did not know I was there. They were both lying down. You could see that misconduct was taking place, that they were having sexual intercourse' ${ }^{33}$ Intercourse in a public place made the adulterous couple more vulnerable to being caught, but other locations such as the family house risked surveillance by the other members of their household or suspicious neighbours.

Most spouses who witnessed their husband or wife having sex in a private home, were already separated, and were actively gathering evidence for a divorce case. For the newly separated, tracking their spouse was a way to bring understanding to the emotional and

\footnotetext{
${ }^{31}$ In 1945 Albert E. explained to the court how he had met a man with whom he became friends, and then who became a boarder in his home. One day, he said, 'I went for a walk and when I came back I found M. with his hand on my wife. I immediately challenged him and ordered him from the house. My wife went hostile and said I should not have done so as he was only consoling her' - E $v E \& M$, AAOM/W3265/ D2297/1945/ANZ-W.

${ }^{32} S v S \& H$, AAOM/W3265/D537/1941/ANZ-W.

${ }^{33} F \vee F$, AAOM/W3265/D1205/1943/ANZ-W.
} 
sexual ending of their relationship, and obtaining evidence for a divorce case was secondary to this purpose. In 1942, one husband, who had the day before been told to leave the marital home, returned to watch what was happening as his wife was hosting a party attended by American soldiers. ${ }^{34} \mathrm{Mr}$ G. told the court that he had gone inside and:

into my wife's bedroom, put the torch on the bed and found my wife and the co-respondent with their arms round each other underneath the bedclothes. I pushed back the bedclothes. My wife had her frock on and C[...] was lying only in his shorts and nothing else on. I called my wife a dirty low swine. She got out of bed and came out and said any rate he has given me something you won't give me. ${ }^{35}$

Mr G. was not the only man to tell the court that his wife had expressed sexual dissatisfaction with their marriage. ${ }^{36}$

With a growing expectation of sexual companionship and emphasis on marriage as a sexual relationship, other divorce cases referred to the lack of sexual intimacy. During the 1920s 'sexual intimacy became an important aspect of the couple relationship, and demands were made for the integration of eroticism, companionship, and mutual support into a relationship with one adult of the opposite sex' ${ }^{37}$ This emphasis increased, and a 'sex education' literature was published for (married) adults from the 1940s. For example, the Australian author Edgar Allan Gornall published three sex advice guides which were available in New Zealand: Biosex-A, directed at adults, Biosex- $F$, directed at adolescent girls and young women, and Biosex- $M$, directed at adolescent boys and young men. ${ }^{38}$ In turn, this emphasis on heterosexual relationships undermined female homosocial networks, and there were an increasing number of educators and doctors who viewed close female friendships as evidence of lesbianism.

\footnotetext{
${ }^{34}$ Marilyn Lake has explored how the presence of American soldiers in Australia during the same period had the effect of sexualizing Australian women, 'The Desire for a Yank: Sexual Relations between Australian Women and American Servicemen during World War II', JHS 2, no.4 (1992): 621-33.

${ }^{35} G v G \& C$, AAOM/W3265/D837/1942/ANZ-W.

${ }^{36}$ In the case of William B. discussed earlier, a letter was presented to the court that William had written to his wife stating, 'And you found out when I married you I could not satisfy you in bed. Well I told you all that before marriage' $-B v B \& C$, AAOM/W3265/D2135/1921/ANZ-W.

${ }^{37}$ Stephanie Coontz. The Social Origins of Private Life. A History of American Families 1600-1900. London and New York: 1988, 351.

${ }^{38}$ Claire Gooder. 'A History of Sex Education in New Zealand, 1939-1985'. PhD thesis, University of Auckland, 2010, 36-38. Gooder notes that Biosex-F and Biosex-M were allowed into New Zealand despite contravening the Indecent Publications Act as that booklets had a 'moral rather than physical focus, which meant they were considered good forms of sex instruction'. Gooder, 38. As well Erik Olssen has highlighted that both Biosex- $F$ and Biosex- $M$ were published within New Zealand by Vital Books which was run by John A. Lee and Norman Douglas, political allies and founding members of the Democratic Labour Party. See Erik Olssen. 'Depression and War (1931-1949)', in The Oxford Illustrated History of New Zealand, $2^{\text {nd }}$ ed., ed. Keith Sinclair. Auckland: 1996, 226.
} 
Perhaps the most well-known marriage guide of the interwar period was Marie Stopes' Married Love, which was censored in New Zealand in $1924 .{ }^{39}$ George Robb has argued that in England, it was primarily middle-class couples who were most affected by advice books. He points out that most working-class people who corresponded with Stopes were interested in obtaining advice about birth control rather than improving sexual technique. ${ }^{40}$ Robb argues that the heightened expectations of marriage, in part created by marriage advice manuals, led to 'resentment when unfulfilled, or performance anxiety among the inexperienced'. ${ }^{41}$ There has been very limited research on the influence of marriage guides in New Zealand although Ruth Hall's edited collection of letters written to Marie Stopes includes two from New Zealand women written in 1922 and $1926 .{ }^{42}$ Both women enquired about birth control advice, and claimed to be writing on behalf of others. In particular they focused on the plight of farming women with numerous children, who were also expected to run a home and work on the farm. The second writer concluded, 'I would so much rather be a cow than an ordinary farmer's wife in New Zealand' ${ }^{43}$ She also stated that she had three adult daughters and that she 'had a reasonable rest between, thanks due to my husband who never dreams of worrying me more than once or perhaps twice in a month'. She contrasts her situation with working-class women claiming, 'the labouring class of man, has less consideration for his wife'. ${ }^{44}$ The example of these two letters suggests that in New Zealand, middle-class women were also interested in being better informed about birth control.

\footnotetext{
${ }^{39}$ Marie Stopes. Married Love, 1918. Edited with an introduction and notes by Ross McKibbin. Oxford:2004; Married Love was very successful in New Zealand, and there was much publicity surrounding its censorship in 1924. Barbara Brookes et al. 'Spare Time? Leisure, Gender and Modernity', in Sites of Gender. Women, Men \& Modernity in Southern Dunedin, 1890-1939. Auckland: 2003, 180. Marie Stopes' Wise Parenthood was deemed an indecent publication by the Customs Department in 1923, and its importation was banned, Ruth Hall, ed. Dear Dr. Stopes. Sex in the 1920s. Letters to Marie Stopes. London: 1978, 124.

${ }^{40}$ Robb, 100. For examples of studies on marriage guides from the post-World War I period see, Alexander C. T. Geppert. 'Divine Sex, Happy Marriage, Regenerated Nation: Marie Stopes's Marital Manual Married Love and the Making of a Best-Seller, 1918-1955'. JHS 8, no.3 (1998): 389-433; Jessamyn Neuhaus. 'The Importance of Being Orgasmic: Sexuality, Gender, and Marital Sex Manuals in the United States, 19201963'. JHS 9, no.4 (2000): 447-73. Also relevant is Ellen M. Holtzman. 'The Pursuit of Married Love: Women's Attitudes Toward Sexuality and Marriage in Great Britain, 1918-1939'. JSH 16, no.2 (1982): 3951 .

${ }^{41}$ Robb, 103.

${ }^{42}$ Hall, $121,131$.

${ }^{43}$ Ibid., 131.

${ }^{44}$ Ibid.
} 
Desertion cases sometimes involved a discussion of the poor quality of a sexual relationship between the husband and wife - usually in the form of the husband claiming he had been deserted by his wife despite her still being in the marital home, because of her refusal to have intercourse with him. ${ }^{45}$ In these cases, wives successfully defended the charge of desertion by arguing they could not have intercourse because of a medical condition usually connected to childbearing. Those who could not claim medical grounds were less successful. Both Glenda Riley and Robert Griswold's studies of similar cases in the United States show American judges, even when there were no medical grounds for refusing intercourse, only reluctantly granted a divorce. ${ }^{46}$ Protection to this degree is not evident in the New Zealand files. Lisa Featherstone, in her study of letters written by women to a male Melbourne doctor in the 1940s, found similar views on sexual rights as those presented in the New Zealand divorce files. Featherstone explains that, ' $[\mathrm{t}]$ hese women implicitly suggest that the right to sex was the male prerogative. Abstinence was seen as the cause of disharmony, with men arguing for their marital "rights" and women aiming to avoid pregnancy'. ${ }^{47}$ While women in the New Zealand divorce files did not explicitly state they were attempting to avoid pregnancy, this is very likely to have been at least a contributing factor in cases involving women of childbearing age. ${ }^{48}$ James Belich has claimed that abstinence played an important role later in marriages, while coitus interruptus and abortion provided back up in an age without effective birth control. $^{49}$

Hera Cook maintains that Australian women had greater control over their fertility within marriage than their English counterparts between the 1890s and 1950s, with Australian women being more likely to use female methods of contraception as well as abortion. She

\footnotetext{
${ }^{45}$ This issue is also discussed in Chapter Six in relation to sexual cruelty. Also highly relevant is Gail Savage's study on marital rape and sexual cruelty in the English Divorce Court. See, Savage. '...the instrument of an animal function': Marital Rape and Sexual Cruelty in the Divorce Court, 1858-1908', in The Politics of Domestic Authority in Britain since 1800, eds. Lucy Delap et al. Houndmills: 2009, 43-57.

${ }^{46}$ Glenda Riley. Divorce. An American Tradition. Lincoln: 1991, 81 and Griswold, 98.

${ }^{47}$ Lisa Featherstone. 'Sexy Mamas? Women, Sexuality and Reproduction in Australia in the 1940s'. AHS 36, no.126 (2005): 243.

${ }^{48}$ By 1900 New Zealand had one of the lowest fertility rates in the industrialised world. This was in part caused by delayed entry into marriage and a significant number of women never marrying. Debate continues as to how married women limited their family size, but any form of contraception would have required the co-operation of their husbands, and abstinence was still the most reliable method. See Ian Pool, et al. The New Zealand Family from 1840. A Demographic History. Auckland: 2007, 46-56 and 109-15. Also suffrage feminists argued that women's sexuality was for reproduction and opposed birth control in favour of abstinence. See Philippa Mein Smith. 'Blood, Birth, Babies, Bodies'. AFS 17, no.39 (2002): 310. ${ }^{49}$ James Belich. Paradise Reforged. A History of the New Zealanders from the 1880s to the Year 2000. Auckland: 2001, 183.
} 
has also contended that heterosexual activity was higher in Australia than it was in England during the same period and 'within this context correspondingly higher levels of sexual harassment and pressure may have been experienced by women who did not wish to participate in sexual activity'. ${ }^{50}$ While Cook's study does not include New Zealand, without any other evidence to draw upon, it would be fair to assume the New Zealand situation was more similar to that of Australia than England, suggesting there was strong pressure and expectations for women to engage in heterosexual intercourse. More generally Cook has argued in another article that there is much evidence to suggest women 'relished the experience' of vaginal penetration but that they withdrew from sexual activity when they had no control over their fertility. ${ }^{51}$ Even when couples had access to contraception, 'the possibility of conception due to method failure was unavoidable until the 1960s' when the contraceptive pill became available. ${ }^{52}$ Throughout the period of this study then, even many women who enjoyed intercourse were reluctant to engage regularly for fear of pregnancy.

Justice Salmond heard a case in which a husband claimed his wife refused to have intercourse with him and this was the sole basis for his claim of desertion in June 1920. The hearing took place over a week, which was unusual as most cases took less than half a day. In a written judgment he summarised the situation:

About six months after the birth of the youngest child, in February 1910, the Respondent refused sexual intercourse with the Petitioner, and has ever since persisted in that refusal. She gave no reason for this refusal other than her dislike of men in general and of her husband in particular. His wife did not exclude him from her house, but at night locked her bedroom door, and one or more of the children slept in her room. ${ }^{53}$

Justice Salmond granted a decree nisi. The wife did not defend this case, and given the details of the marriage that were revealed, it seems likely she was just as happy with the outcome of the court case as her husband presumably was. The wife's decision to sleep

\footnotetext{
${ }^{50}$ Hera Cook. 'Unseemly and Unwomanly Behaviour: Comparing Women's Control of their Fertility in Australia and England from 1890 to 1970'. Journal of Population Research 17, no.2 (2000): 125-41.

${ }^{51}$ Hera Cook. 'Sexuality and Contraception in Modern England: Doing the History of Reproductive Sexuality'. JSH 40, no.4 (2007): 918. See also, Hera Cook. 'The English Sexual Revolution: Technology and Social Change'. HWJ 59 (2005): 109-28; Hera Cook. The Long Sexual Revolution. English Women, Sex, and Contraception 1800-1975. Oxford: 2004. For a different view on the use of birth control in Britain, which emphasises the role husbands played in obtaining and practising contraception see, Kate Fisher. Birth Control, Sex, and Marriage in Britain 1918 - 1960. Oxford: 2006, especially, 189-237.

${ }^{52}$ Hera Cook. 'Demography', in The Modern History of Sexuality, eds. H.G. Cocks and Matt Houlbrook. Houndmills: 2006, 25.

${ }^{53} E v E$, AAOM/W3265/D1831/1919/ANZ-W.
} 
with her children and exclude her husband from her bedroom was not unusual and Marilyn Lake has argued that the sleepout 'was important to marital negotiations between the sexes, its separate space affording some relief from the tensions surrounding sexual relations and the associated fear of pregnancy'. ${ }^{54}$ She goes on to argue that smaller houses meant many couples could not have a separate marital bedroom and this meant 'women might not have been (or felt) so isolated and vulnerable to "men's lusts"،. 55

Not all husbands were successful with their arguments of desertion based on their wives' refusal to have intercourse. Arthur S. of Dunedin petitioned the Wellington Court for divorce in 1919 as he was at Trentham (an army camp at Upper Hutt, just outside of Wellington) on military service, on the ground of his wife's refusal to have intercourse. His wife Mary defended the case, claiming intercourse had been very painful for her, since the birth of her youngest child in 1893. Her lawyer asked her:

Lawyer: Why did you put up with it?

Answer: Just because I thought it was a man's rights, that was all.

L: Did you honestly endeavour to give him what you considered his rights?

A: Yes.

L: Did you allow him to have intercourse although it caused you pain?

A: Yes. ${ }^{56}$

Mary S. was supported by her doctor and youngest daughter who also gave evidence to the court. The court dismissed her husband's petition and he was ordered to pay her almost $£ 70$ costs. In 1931 Maata A. complained her marriage had been deteriorating for some time, with her husband Thomas insisting 'upon undue sexual intercourse thereby injuring [her] health' ${ }^{57}$ While the court was prepared to support some women in their refusal to have intercourse, it was on the basis of the woman's poor physical health, coupled with the view that husbands were insensitive in making sexual demands on their wives in such a situation. There was never any suggestion the husbands were themselves 'over-sexed'. The argument was rather that as wives had suffered health problems resulting from their 'duty' as a child bearer, husbands should show extra restraint, and needed to live with, and accept the situation. To do otherwise was considered an act of

\footnotetext{
${ }^{54}$ Marilyn Lake. 'Historical Homes'. AHS 24, no.96 (1991): 48.

${ }^{55}$ Lake, 49.

${ }^{56} S v S$, AAOM/W3265/D1603/1918/ANZ-W.

${ }^{57} A \cup A \& E$, AAOM/W3265/D3820/1931/ANZ-W.
} 
cruelty, and while marital rape was not a crime at this time, the courts would not support husbands who made excessive sexual demands of their wives. ${ }^{58}$

Other desertion cases which included allegations of refusal to have intercourse did not base their claims solely on that refusal, but rather used the refusals to help explain the gradual loosening of the relationship. In 1919, Walter I. told the court, 'it was in 1913 that I last had marital intercourse with my wife. The reason was my wife told me she loved another man. My wife refused to have intercourse with me' ${ }^{59}$ His wife had subsequently left the marital home and it was this that formed the more substantial basis of his argument of desertion. In a 1942 case where Frederick S. sought to divorce his wife on the ground of adultery, he explained to the court that,

previously I had noticed signs of waning affection for two or three years. She would go to bed and sham to be asleep and always tried to find some argument about something... She was contrary and her affection was always opposite to mine... Sexual intercourse had been waning for 2 or 3 years before that - she had had an attraction before that. ${ }^{60}$

The fact that she had previously been interested in having intercourse, and her interest had subsided, reinforced her husband's claim that she was having a sexual relationship with another man and her sexual needs were being met elsewhere. This testimony acknowledged that wives had sexual needs, a view that did not appear in the files from the earlier part of the century.

There were a small number of cases which went through the same legal procedure as divorce cases, but were in fact petitions for annulment based on the non-consummation of the marriage. Unlike those cases where a lack of intercourse contributed to the argument for divorce, these cases were based solely on the claim that the marriage had not been consummated. Providing the petitioner pursued the case the marriage was always nullified. When husbands did not consummate the marriage it was expressed as an 'inability' whereas when wives did not consummate the marriage it was explained as a 'refusal' which subsequently led to an inability to consummate the marriage. For example, one husband stated in his petition that his marriage had not been consummated due to,

\footnotetext{
${ }^{58}$ Gail Savage makes a similar argument about the situation in England. See, "A State of Personal Danger": Domestic Violence in England, 1903-1922,' in Violence and Civilisation in Historical Context, ed. Katherine D. Watson. Newcastle: 2007, 282.

${ }^{59}$ I $v$ I, AAOM/W3265/D1811/1919/ANZ-W.

${ }^{60} S v S \& H$, AAOM/W3265/D537/1941/ANZ-W.
} 
the invincible repugnance of the said Laurestina $R$. to sexual intercourse with the petitioner rendering her incapable of consummating the said marriage, or by reason of the unreasoning refusal of said Laurestina $\mathrm{R}$. to permit the petitioner to have sexual intercourse with her rendering her incapable of consummating the said marriage. ${ }^{61}$

As he did not pursue the case, the marriage was not nullified.

Over the period from 1898 to 1947, New Zealanders increasingly turned to divorce to end legal relationships that had already ceased to exist as intimate, personal relationships and often as economic relationships. Various allegations regarding sexual behaviour showed how the relationship between sexuality and marriage was contested by husbands and wives. Moreover, the types of revelations that it was necessary to make in court, either to fulfil legal requirements or fulfil a personal need to seek revenge and shame one's spouse, required bringing 'twilight moments' into broad daylight. This acted as a form of punishment for those who had transgressed expected behaviours, and served as a warning to those who were considering such actions, as well as providing salacious copy for Truth. It also provided an opportunity for 'wronged' spouses to seek personal revenge. At the same time as Anna Clark explains,'[a]fter being punished or purged by whispering campaigns, public exposure, fines, or some other measure perpetrators were allowed to return to society. Such sanctions might make life hard for those accused but did not necessarily drive them from the community or define them as abject'. ${ }^{62}$ While divorce cases revealed intimate, sometimes potentially embarrassing details, divorce ultimately provided an opportunity for people to form new publicly sanctioned unions by being able to remarry. In many cases this meant that their actions and sexual relationships no longer had to remain secret, and they were able to regain a degree of 'respectability'.

\footnotetext{
${ }^{61} R v R$, AAOM/W3265/D2935/1926/ANZ-W.

${ }^{62}$ Clark, 'Twilight Moments', 151.
} 


\section{Epilogue and Conclusion}

On 7 February 1959, the Evening Post reported that David and Maria Prince of Palmerston North were the longest-married couple in the British Empire. Married in 1883, they had just celebrated their $76^{\text {th }}$ wedding anniversary. The report went on to describe the celebration:

Guests included civic dignitaries, officers of the Salvation Army, of which both have been members for many years, and members of their family. Among the latter were two of their four great-great-grandchildren. The Princes held "open house" throughout the afternoon as friends dropped in with gifts of fruit and flowers. Telegrams were received from the Prime Minister (Mr Nash) and from civic leaders.

A decade and a half after the end of World War II, marriage still clearly constituted an important and celebrated public institution as well as an intimate relationship between two individuals. The extent of the interest in the Princes long-lived marriage, however, may have also reflected the fears that this 'sacred' institution was under threat. In her recent work on welfare in New Zealand, Margaret Tennant states, there 'was seldom a time in New Zealand history when the family was not seen as under threat, young people as disorderly, and women as failing in their maternal responsibilities'. ${ }^{2}$ The marital upheaval, represented by dramatically increased divorce rates, which occurred during World War II, alarmed opinion-makers, politicians, religious leaders, sectors of the media, and some sections of the public. The collective anxieties resulted in new strategies and attempts to help couples keep their marriages intact.

In New Zealand and in other countries such as Britain, the postwar divorce rate was considered to be 'something approaching a social disaster'. ${ }^{3}$ Such a perception was created, in part, by a growing awareness of the actual number of people divorcing. Newspapers published stories of individual divorces and reports on the annual divorce statistics collated by the government. On 17 September 1946 the Evening Post ran a story with the headline: 'Divorces in NZ. Enormous Increase. World-Wide Problem'. The article explained,

\footnotetext{
1 'Longest Married of any Empire Couple'. EP, 7 February 1959.

${ }^{2}$ Margaret Tennant. The Fabric of Welfare. Voluntary Organisations, Government and Welfare in New Zealand, 1840-2005. Wellington: 2007, 134.

${ }^{3}$ David H.J. Morgan. 'Marriage and society: understanding an era of change', in 'Whom God Hath Joined Together'. The Work of Marriage Guidance, eds. Jane Lewis, et al. London and New York, 1992, 22.
} 
an enormous increase in the number of divorce suits filed in New Zealand during the past decade is revealed in figures published in the "Abstract of Statistics."...A special study of divorce statistics is being made by the Census and Statistics Department, and conclusions drawn will shortly be published in bulletin form. These conclusions include:- The problem of divorce is worldwide and has been accentuated by the chaotic conditions resulting from war and economic upheaval. ${ }^{4}$

Accompanying such public attention was a new terminology describing divorced couples and families. Phrases including 'broken homes' and 'bad marriages' became linked to popular explanations for juvenile delinquency and adult criminality. ${ }^{5}$ The Evening Post, for example, asked whether husbands took 'enough interest in home matters' and published articles on 'marriage and problems of the modern world' or emphasised that 'keeping people married is no easy task'. ${ }^{6}$ Marriage problems had begun to attract the attention once reserved for other staples of news coverage.

The formation of marriage guidance councils in New Zealand from the late 1940s represented one form of intervention to help people have better marriages or get out of existing marriages in a more civilised manner. Marriage Guidance had emerged in the United States in 1920s and in Britain during the late 1930s. Councils formed in Australia, as they did in New Zealand, in the postwar years. These modelled themselves on, and were affiliated to, the British National Marriage Guidance Councils. Dr David Mace, founding general secretary of the British organisation and a former Methodist minister, visited New Zealand in 1956 with his wife Vera to explain its organisational goals. Both gave many public addresses during their visit thus helping to popularise the notion of marriage guidance and the responsibilities of husbands and wives to work on their relationships.

In this environment with an emphasis on a return to peacetime order and prosperity, the young Queen Elizabeth II and Prince Philip, who toured New Zealand in 1953-54,

\footnotetext{
4 'Divorces in NZ. Enormous Increase. World-Wide Problem'. EP, 17 September 1946.

${ }^{5}$ See for example, 'Broken Homes and Effect of Children' EP, 22 November 1951; 'Broken Marriages Seen as Insecurity's Result'. EP, 22 October 1958.

6 'Do Husbands Take Enough Interest In Home Matters?' EP, 4 November 1949; 'Marriage and Problems of Modern World'. EP, 17 July 1956; 'Keeping People Married Is No Easy Task'. EP, 9 September 1957. See also, 'Too Many Deserting Husbands?' EP, 6 November 1950; 'Bad Housing Breaks Marriages, Says Mrs Ross'. EP, 7 November 1950; 'Industrial Discord Produced Echo In The Homes'. EP, 14 October 1951; 'Delinquency Is Reflection Of Bad Marriages’. EP, 18 July 1956.
} 
symbolised the happy and successful marriage and family. ${ }^{7}$ Married in 1947 and crowned in 1953, the Queen represented the model mother and wife with her young children providing an important image of postwar hopes and promises and a focus on young families. Even the Royal family, however, found it difficult to live up to this image. A potential problem was averted when Princess Margaret, the Queen's younger sister, decided to end her relationship with Peter Townsend as he was divorced. Neither the Queen, nor the British government, nor the Dominion Prime Ministers, would agree to her marrying him. If Margaret had married Townsend, she would have had to renounce her rights of succession, showing the seriousness of the issue of divorce for a royal family still troubled by Edward VIII's abdication. Princess Margaret received praise for recognising 'her duty in upholding the sanctity of marriage as a lifelong institution'. ${ }^{8}$ Bent on restoring marriage to its presumptive place as the foundation for social order, ruling elites and commoners alike set out to ensure marital longevity.

The gap between what ought to be and what was, apparent in Princess Margaret's romantic relationships, gained more public attention in the post-World War II period. On the one hand, a strong discourse emphasized the importance of marriage and families and 'appropriate' gender norms. Accompanying this discourse, however, was the acknowledgement that relationships were not easy, but required hard work, and, especially for women, the roles of wife, mother and homemaker did not always offer the fulfilment portrayed in advertisements and women's magazines. ${ }^{9}$ Katherine Caldwell has examined what she calls the 'incongruence between dominant values and social experience'. ${ }^{10}$ While there was room within the discourse to explore discontent and difficulties, the solutions usually recommended conformity, or at least its appearance to ideals of domesticity, happy families, and marital bliss. This period also witnessed the

\footnotetext{
${ }^{7}$ For a history of the royal tour of New Zealand see, Jock Phillips. Royal Summer. The Visit of Queen Elizabeth II and Prince Philip to New Zealand 1953-54. Wellington: 1993.

${ }^{8}$ Helen Cook. 'The Art of Marriage as a Career for the 1950s'. NZ Women's Studies Journal 2, no.1 (1985): 65. Princess Margaret married Antony Armstrong-Jones in 1960. They divorced in 1978.

${ }^{9}$ For further exploration of these ideas in the American context see, Eva Moskowitz. 'Women's Magazines and a Discourse of Discontent, 1945-1965'. JWH 8, no.3 (1996): 66-98. Jessamyn Neuhaus has shown how cookbooks acknowledged the tediousness of cooking daily meals for families. See, 'The Way to a Man's Heart: Gender Roles, Domestic Ideology, and Cookbooks in the 1950s'. JSH 32, no.3 (1999): 447-73. For the New Zealand context regarding women's magazines see, Courtney Evans. "Not Aunt Daisy": Ambivalence in the Representation of Women in Postwar New Zealand'. MA thesis, University of Auckland, 2005; Helen May. Minding Children, Managing Men - Conflict and Compromise in the lives of Postwar Pakeha Women. Wellington: 1992; Carole A. Bannister. 'Attitudes to Marriage in Selected New Zealand Periodicals 1960-1969'. BA(Hons) research essay, University of Otago, 1991.

${ }^{10}$ Katherine L. Caldwell. 'Not Ozzie and Harriet: Divorce and the American Liberal Welfare State'. Law \& Social Inquiry 23, no.1 (1998): 2.
} 
growth of the 'expert' to provide advice to troubled marriages. Social scientists, psychologists and others providing advice on marriages and family life gained increasing influence in the postwar era building on the growing influence of psychology, psychiatry and psychoanalysis. ${ }^{11}$ Beth Bailey sees experts as "much a product of the transformation of American culture as the new mores they hoped to "adjust". They were part of a much larger twentieth century movement toward centralized power, a movement which sought to control the chaotic forces of modernization by vesting power in a new class of experts and professionals'. ${ }^{12}$ These new experts also took up work in New Zealand.

Mona Gleason, in looking at postwar Canada, has considered the ways in which psychologists utilised the concept of 'normal' and how this concept came to construct 'normal families' and to be used in instructing Canadians on how to achieve normalcy. ${ }^{13}$ She explains,

[t]he normal family that this discourse constructed had mothers who stayed at home and raised well-adjusted, bright, industrious children, and white-collar fathers who skilfully divided time between the office and home. In this way, an idealized "every family" became the standard against which the unique needs and circumstances of those outside the ideal, such as immigrant, working-class, non-nuclear, or female-headed families, were measured and judged. $^{14}$

She also states that psychologists highlighted what was 'abnormal' in order to explain what was 'normal'. In particular they focused on 'abnormal' personality development in children, and this was also a major concern in New Zealand and will be explored later in this chapter. ${ }^{15}$ Langhamer has explored how in postwar England while there was a 'softening' attitude towards pre-marital sex, attitudes towards extra-marital sex became 'increasingly negative even as it became apparently more common'. ${ }^{16}$

While most women's magazines and newspapers emphasized what wives could do to improve their marriages, husbands also became subject to prescriptive roles. In $1949 \mathrm{Mrs}$

\footnotetext{
${ }^{11}$ Pat Thane. 'Family Life and "Normality" in Post-War British Culture', in Life After Death. Approaches to a Cultural and Social History of Europe during the 1940s and 1950s, eds. Richard Bessel and Dirk Schumann. Cambridge: 2003, 194.

${ }^{12}$ Beth L. Bailey. 'Scientific Truth....and Love: The Marriage Education Movement in the United States'. JSH 20, no.4 (1987): 714.

${ }^{13}$ Mona Gleason. 'Psychology and the Construction of the "Normal" Family in Postwar Canada, 1945-60'. The Canadian Historical Review 78, no.3 (1997): 443.

${ }^{14}$ Ibid., 444.

${ }^{15}$ Ibid., 466.

${ }^{16}$ Claire Langhamer. 'Adultery in Post-war England'. HWJ, no.62 (2006): 88.
} 
Robertshawe, at an evening talk organised by the Family Guidance Council in Wellington, warned that the 'idea of family' had 'disappeared in the pursuit of romance, the attractions of sex, excessive emphasis on artificial aids to beauty, allure and glamour, and other diversions, which just did not go with having a family'. She worried that the 'modern girl' had been 'pampered and given an "awfully good time" leaving her unprepared for the responsibilities of marriage while her husband had 'exactly the same idea as his wife'. ${ }^{17}$ A decade later the Evening Post ran an article on what women considered to be the attributes of a 'perfect man'. These included:

- He must be able to offer his wife a comfortable life.

- He must also be thrifty enough to leave his wife - in case he dies before her - a small fortune.

- He must be provident, chivalrous, and faithful.

- He must not forget birthdays and other anniversaries.

- He must be fond of dancing, masculine, grateful, punctual, responsible, temperamental, and gallant.

As well, 'the perfect man' should not:

interrupt his wife when she is talking, should not read his newspaper at the breakfast table, should occasionally find a word of praise for the food, occasionally find a tender word, and take his wife out frequently. He should not be a habitual drinker, should not look at other women in the streets, should not speak of the advantages of other women, should not neglect his appearance in the home. ${ }^{18}$

Men and women both needed to change their attitudes and behaviours in the views of the experts to achieve a happy home life.

The expert-guided search for personal fulfilment in marriage and raising children was paradoxically, as David Morgan has identified, mass produced. ${ }^{19}$ Increasing numbers of advice books encouraged certain norms in marriage. In this period of almost universal marriage, marriage was considered to be the typical adult status. ${ }^{20}$ Bettina Bradbury has noted that in Canada during this time, as part of enforcing the normalcy of married heterosexual couples, gays and lesbians found themselves 'expelled from the civil service and faced police harassment in city bars and hotels' and facing enormous difficulties in

\footnotetext{
17 'Modern Girls Pampered By Mothers. Glamour Counts More Than Families'. EP, 18 November 1949.

18 'The Ideal Man - 1958 Model!' EP, 27 September 1958.

${ }^{19}$ Morgan, 17.

${ }^{20}$ Ibid., 16. Claire Langhamer has argued that "marriage was the "normal" state for adults in mid-century England'. See 'Love and Courtship in Mid-Twentieth-Century England'. The Historical Journal 50, no.1 (2007): 179. Claire Gooder has emphasised that 'marriage was fundamental in sex education for unmarrieds'. See 'A History of Sex Education in New Zealand, 1939-1985'. PhD thesis, University of Auckland, 2010, 41.
} 
living openly in same-sex couples. ${ }^{21}$ Likewise, Claire Langhamer has argued that in England 'dominant discourses of romantic love, ultimately worked to contain men and women within heterosexual monogamous marriage'. ${ }^{22}$ Accompanying this focus on personal fulfilment through marriage and family was the process of developing stateorganised benefit systems based upon the structure of family. Judy Giles has argued that 'the focus on domesticity and its minutiae by government and official bodies was unprecedented' in Britain during this period as successive governments debated the nature of marriage, the role of wives and mothers, the need for adequate housing and financial support for mothers and families. While 'the outcomes were not always favourable to women generally and specific age groups in particular, issues around women's roles informed debates about industrial productivity and the responsibilities of the welfare state'. ${ }^{23}$ Katherine Caldwell similarly discussed 'the state's increased involvement in citizens"' marital ties' in which increasing divorce rates represented a part of 'a larger shift toward greater state regulation of public welfare, rather than the law's failure to stabilize the marital relationship'. ${ }^{24}$ In the United States, although not usually delivered through the state welfare system, benefits such as health insurance and pensions followed the same logic. Family relationships meditated access to employer-provided benefits making family stability quite important to other aspects of human wellbeing.

Accompanying the growth in the power of experts, governmental, media, and business emphasis on marriage, was the idea that marriages demanded work to maintain them. Kristin Celello, in her recent study of marriage and divorce in the United States, has identified the 'marriage as work' formula as a response 'to specific changes in marriage patterns, most notably the growing incidence of divorce in the white middle class. Furthermore, what it meant to work at your marriage, as well as the question of who performed this work, was by no means static, and, indeed, frequently contested' ${ }^{25}$ The hope was that by working at their marriages Americans could reduce the incidence of divorce and find greater personal fulfilment in 'stronger more satisfying marital

\footnotetext{
${ }^{21}$ Bettina Bradbury. 'Social, Economic, and Cultural Origins of Contemporary Families', in Families. Changing Trends in Canada, $4^{\text {th }}$ ed, ed. Maureen Baker. Toronto: 2001, 92.

${ }^{22}$ Langhamer, 'Love and Courtship', 195.

${ }^{23}$ Judy Giles. The Parlour and the Suburb. Domestic Identities, Class, Femininity and Modernity. Oxford: 2004, 162.

${ }^{24}$ Caldwell, 5 .

${ }^{25}$ Kristin Celello. Making Marriage Work. A History of Marriage and Divorce in the Twentieth-Century United States. Chapel Hill: 2009, 2.
} 
relationships'. ${ }^{26}$ In the United States, the idea of working at one's marriage was not new in the post-World War II years, but concerns about public welfare, divorce and its detrimental effects became heightened at this time. ${ }^{27}$

In New Zealand, as in many other western countries, the end of World War II did not mean an end to hardship. In its annual report in September 1946, the Society for the Protection of Women and Children identified many problems families were facing readjusting to postwar life. In particular, it highlighted the difficulties wives faced who were used to being independent from their husbands. This was attributed to there having many New Zealand men serving overseas as well as having significant numbers of American soldiers in New Zealand, and the general economic upheaval caused by the war. The report also focused on the sharp increase in the divorce rate and the negative impact that divorce was believed to have on children. ${ }^{28}$ Rationing continued and there was a severe housing shortage. ${ }^{29}$ In a culture that placed importance on newlyweds beginning their life together in their own home, this was highly problematic. Erik Olssen has shown that in the southern Dunedin suburbs, for a slightly earlier period, 77.1 per cent of newlyweds set up their own homes immediately after marriage, showing a preference for newly-weds having their own home, with some delaying marriage in order to achieve this. ${ }^{30}$ In November 1950, Hilda Ross, Minister for the Welfare of Women and Children, spoke at the annual meeting of the Society for the Protection of Women and Children. She claimed that, '[m]any broken homes...could be attributed to bad housing conditions, which bred discontent'. ${ }^{31}$ At the same time, new housing that was built in outer suburbs 'promoted more privatised households, less embedded within their communities'. ${ }^{32}$ Generally, in the postwar period people had higher expectations of housing, and the focus was on home ownership rather than renting a state house, with the National government limiting the eligibility for state houses to those on low incomes from 1950, and giving

\footnotetext{
${ }^{26}$ Ibid., 3 .

${ }^{27}$ Ibid., 85.

${ }^{28}$ SPWC $49^{\text {th }}$ Annual Report year ending $30^{\text {th }}$ September 1946, 3, Annual Reports 1932-1966, MSX-3294, ATL. See also 'Cause of Broken Homes. Bad Housing Conditions'. EP, 15 August 1945.

${ }^{29}$ For the English situation see, Ibid., 341-62. For Canada see, Veronica Strong-Boag. 'Home Dreams: Women and the Suburban Experiment in Canada, 1945-60'. The Canadian Historical Review 72, no.4 (1991): 483-89.

${ }^{30}$ Erik Olssen. "“For Better or Worse": Marriage Patterns in Dunedin's Southern Suburbs, 1881-1938', in Class, Gender and the Vote. Historical Perspectives from New Zealand, eds. Miles Fairburn and Erik Olssen. Dunedin: 2005, 79.

31 'Bad Housing Breaks Marriages, Says Mrs Ross'. EP, 7 November 1950.

${ }^{32}$ Michael Gilding. The Making and Breaking of the Australian Family. Sydney: 1991, 46.
} 
tenants the opportunity to purchase their homes. ${ }^{33}$ Graeme Dunstall has highlighted the postwar focus on home ownership and the 'vast tracts of suburban two- to threebedroomed bungalows' which were built expressing 'the need for privacy and space. ${ }^{34}$ In practice, however, it was not always possible for couples to fulfil these desires, particularly early in their marriage, and this could cause tensions within the relationship.

At the same time, there were a number of factors which made the postwar generation distinctive from previous and subsequent generations. These patterns were not only seen in New Zealand, but in all western countries. This was a time of almost universal marriage, a declining age at marriage and high fertility, marking the end of the Western European 'centuries-old pattern' of a high age at marriage and a high proportion of the population never marrying. ${ }^{35}$ This period is usually referred to as the 'Baby Boom' but Bronwyn Labrum has argued it was in fact a 'Marriage Boom'. The increased birth rate was primarily a result of universal marriage rather than large families. ${ }^{36} \mathrm{New}$ Zealand's 'wide-ranging social security system', was designed to assist 'the increasing population, the spread of consumerism, and the focus on suburban homes and families' ${ }^{37}$ A very low proportion of one-parent families together with financial stability meant most families, including working-class families, could survive on a single wage. ${ }^{38}$ Marriage was promoted as the only way to adult happiness. ${ }^{39}$ This period has been characterized as the 'golden age' of marriage. ${ }^{40}$ Langhamer has argued that the 'dreams and aspirations' realised in the 1950s, had first been formulated in the 1930s. She claims that 'pre-existing demographic trends framed and fuelled the desire for, and possibility of, a more home-

\footnotetext{
${ }^{33}$ Margaret McClure. A Civilised Community. A History of Social Security in New Zealand 1898-1998. Auckland: 1998, 151. Also, Bronwyn J. Labrum. 'Family Needs and Family Desires: Discretionary State Welfare in New Zealand, 1920-1970'. PhD thesis, Victoria University of Wellington, 2000, 74.

${ }^{34}$ Graeme Dunstall. 'The Social Pattern', in The Oxford History of New Zealand, $2^{\text {nd }}$ ed. ed. Geoffrey Rice. Auckland: 1992, 458. See also, Louise Shaw. 'A Woman's Place?', in At Home in New Zealand. History, Houses, People, ed. Barbara Brookes. Wellington: 2000, 165-80.

${ }^{35}$ Ibid., 454. For the Canadian situation see, Strong-Boag, 471-504.

${ }^{36}$ Labrum, 'Family Needs and Family Desires', 42. See also Stephanie Coontz. Marriage, a History. How Love Conquered Marriage. New York: 2005, 229-44.

${ }^{37}$ Bronwyn Labrum. 'Persistent Needs and Expanding Desires: Pākehā Families and State Welfare in the Years of Prosperity', in Fragments: New Zealand Social and Cultural History, eds. Bronwyn Dalley and Bronwyn Labrum. Auckland: 2000, 189. Despite this extensive social security system, a growing number of New Zealanders also used discretionary welfare services, suggesting that the so-called 'generous' social security system was not so generous, and that for some, the 1950 s was a decade of 'disparity, pressure and discontent'. Labrum, 207.

${ }^{38}$ Bradbury, 90.

${ }^{39}$ May, 90.

${ }^{40}$ Thane, 198. Bronwyn Labrum has referred to the period 1950-1967 as 'the golden years' for Pakeha New Zealanders. See 'Persistent Needs and Expanding Desires', 189.
} 
centred way of life, whilst "modern" domesticity pre-dated the end of the war'. ${ }^{41} \mathrm{~A}$ decreasing age at marriage, increasing life expectancy, and the use of birth control meant that child bearing ceased much earlier in marriages, while the potential length of marriages increased dramatically, especially the period after children had reached adulthood and left home. This placed an increased importance on the husband-wife companionate relationship. Miriam Gilson, writing in 1970 when this marriage pattern was still dominant, explained, '[t]he need for this companionship is intensified, in many cases, by more frequent change of residence which, by physically removing families from established friendships and activities, increases their dependence on one another for security and companionship, at least until new associations are formed'. ${ }^{42}$ Marriage guidance tried to teach couples how to operate successfully within this pattern to decrease the prevalence of divorce.

While there was an increasing emphasis on couples finding sexual satisfaction and compatibility in marriage, 'there were in the 1940s and 1950s strict codes governing what might be known and talked about'. ${ }^{43}$ Sex within marriage was beginning to be discussed, and marriage manuals 'were stressing the desirability of pleasurable sex within marriage for women as well as men'. ${ }^{44}$ The first Family Planning clinic, however, did not open in New Zealand until 1953, which by international standards was comparatively late, and meant that not all couples had access to reliable information about birth control, although the Pakeha family size had dropped massively between the 1880s and 1914 and continued to do so thereafter. As the previous chapter has shown, this often decreased women's desire to enjoy intercourse as they were fearful of getting pregnant.

Not everyone supported the turn to marriage guidance. Conservative clergy believed they should offer marriage counselling when necessary, and opposed the rise of marriage guidance services run by psychologists and other 'lay experts'. In contrast, progressive Protestant clergy strongly supported such services in New Zealand. ${ }^{45}$ Tennant has argued

\footnotetext{
${ }^{41}$ Claire Langhamer. 'The Meanings of Home in Postwar Britain'. Journal of Contemporary History 40, no. 2 (2005): 342-43.

${ }^{42}$ Miriam Gilson. 'The Changing New Zealand Family: A Demographic Analysis', in Marriage and the Family in New Zealand, ed. Stewart Houston. Wellington: 1970, 62.

${ }^{43}$ May, 95.

${ }^{44}$ Ibid., 101.

${ }^{45}$ For the Australian context see David Hilliard. 'Church, Family and Sexuality in Australia in the 1950s'. AHS 27, no.109 (1997): 139. For a history of Catholic marriage in post-World War II England see, Alana Harris. "“A paradise on earth, a foretaste of heaven": English Catholic Understandings of Domesticity and
} 
that despite Marriage Guidance being a secular organisation, it was 'not without religious inspiration', and this is confirmed by the large number of clergy involved. ${ }^{46}$ This religious support was important in the 1950s, where in Britain, the United States and Australia there was a surge in church attendance and Sunday school enrolments. David Hilliard has described the 1950s as a 'family-centred decade'. ${ }^{47}$ There was a focus on strengthening familial relations with "ministers, pastors and priests [calling] for more "family religion": family prayer at home, family worship on Sundays, the placing of the church at the centre of family life'. ${ }^{48}$ One example was the National Family Rosary Crusade, which was conducted in New Zealand and Australia in 1953 and 1954 by an Irish-American priest, Father Patrick Peyton, under the slogan: 'The Family that Prays Together...Stays Together', which encouraged families to say the rosary as a group. ${ }^{49}$ When Billy Graham, the American evangelist, toured in 1959, 40,000 people went to listen to him at Athletic Park in Wellington, including the Prime Minister, Walter Nash. ${ }^{50}$

The setting up of marriage guidance services acknowledged that marriages needed to be constantly worked on and that marriages required regular reinforcement. This was a result of viewing marriage 'increasingly as a dynamic relationship rather than a formal, permanent social status'. ${ }^{51}$ The type of reinforcement that marriage guidance and counselling services provided differed from other forms of religious, moral, or legal reinforcement in that the practitioners attempted to understand what caused relationships to dissolve and tried to help people accordingly, rather than condemning divorce as immoral and apportioning blame for the demise of the marriage. The emphasis placed on 'keeping people married' is indicative of the privileged and central position of marriage and the belief that stable marriages were necessary for a stable society. At the same time, marriage guidance services made it possible to end marriages which could not be repaired,

\footnotetext{
Marriage, 1945-1965', in The Politics of Domestic Authority in Britain since 1800, eds. Lucy Delap, et al. Houndmills: 2009, 155-81.

46 Tennant, 137.

${ }^{47}$ Hilliard, 135-36; Callum G. Brown. The Death of Christian Britain: Understanding Secularisation, 18002000. London: 2000. Brown argues that it was not into the 1960s that the marked decline of religious observance occurred in Britain. See also Callum G. Brown. Religion and Society in Twentieth-Century Britain. Harlow: 2006.

${ }^{48}$ Hilliard, 138.

${ }^{49}$ Ibid.

${ }^{50}$ Bronwyn Dalley. 'The Golden Weather, 1949-1965', in Frontier of Dreams. The Story of New Zealand, eds. Bronwyn Dalley and Gavin McLean. Auckland: 2005, 335.

${ }^{51}$ Kerreen Reiger. 'The Coming of the Counsellors: The Development of Marriage Guidance in Australia'. Journal of Sociology 23, no.3 (1987): 381.
} 
something obviously opposed by religious leaders who rejected the possibility of divorce or the emphasis on mutual satisfaction as the goal of marriage.

Marriage Guidance did not just address the 'problem' of those whose marriages were considered to be 'in danger' but it expressed the idea that good marriages could always be made better. ${ }^{52}$ Marriage Guidance Councils advocated the need for 'adequate preparation for marriage' reflecting the view that too many people made the decision to marry without enough consideration. ${ }^{53}$ In addition, the importance of husbands and wives making constant efforts to improve their relationships was emphasised with much discussion about what it was to be a husband or wife. While both were expected to contribute to their relationships there was an emphasis placed on the responsibility of wives to improve their marriages. Marriage was not something that stopped with courtship, engagement and a wedding. More generally, the rise of marriage guidance reflected growing expectations about marriage, and the efforts to prevent disappointment and frustration from occurring when these expectations were not met, as well as a growing desire for marriages to be the central source of contentment and satisfaction in people's lives. While not explicitly advertised, marriage guidance also provided a way to negotiate more 'civilised', less acrimonious divorces.

With all this emphasis on the problem of divorce and other related problems, it is not surprising that some New Zealanders saw the need to establish Marriage Guidance Councils. Such efforts had been tried earlier in the 1930s to 'save' marriages. In 1938 the Justice Department considered setting up Courts of Domestic Relations based on Courts which had been set up in England. ${ }^{54}$ The following year, the Domestic Proceedings Act was passed which 'introduced the concept of conciliation, at the point of marriage breakdown. ${ }^{55}$ Conciliators were a mixed bag of people nominated by the community through a Magistrate'. ${ }^{56}$ World War II, however, prevented the scheme being used to any significant extent. The postwar period offered a better opportunity and also made apparent the need for action. Accordingly, the first council formed in Christchurch in February 1948 with Reverend Edgar Blamires present and able to share his knowledge of

\footnotetext{
${ }^{52}$ Celello, 2.

${ }^{53}$ Ibid.

54 'Domestic Courts. Conciliation Plan. Marriage Disputes. Consideration in NZ'. EP, 29 October 1938.

${ }^{55}$ Domestic Proceedings Act 1939 (3 GEO VI 1939 No. 13).

${ }^{56}$ Jennifer M. Daly. MG Reflecting. A Portrait of Marriage Guidance New Zealand 1949 to 1989. Wellington: 1989, 15.
} 
the British Marriage Guidance Council from a period spent in Britain studying its Council. ${ }^{57}$ Also present at the Christchurch meeting was Dr Eleanor Mears, a gynaecologist, who was elected a vice-president of the organisation. ${ }^{58}$ The Christchurch group was affiliated with the National Marriage Guidance Council of Great Britain. ${ }^{59}$ A variety of people were involved in setting up Marriage Guidance with liberal clergy, doctors and other middle-class professionals featuring prominently.

In the time immediately following its establishment, relatively few people sought the assistance of the Guidance Councils causing disillusionment among their active members. For example, in Dunedin the Council organised a series of public lectures in July and August 1951. Their three youth talks attracted audiences of zero, six and two, and the adult series attracted two people. ${ }^{60}$ The Council disbanded due to a lack of support. The debates the organisation precipitated, however, had a wider impact, and a number of magazines paid increasing attention to the ideas underpinning marriage guidance, especially the New Zealand Women's Weekly. ${ }^{61}$ As a result, the Dunedin Council reformed in 1961 as part of an increasing awareness and support of marriage guidance in the New Zealand community. ${ }^{62}$ The meeting in April 1961 when the council was reformed was chaired by the mayor Thomas Sidey; 45 people attended the meeting. ${ }^{63}$

The reticence about seeking advice from Marriage Guidance may in part be explained by the 'crisis' precipitated by the Parker-Hulme murder in Christchurch in June 1954 and the consequent scandal. Hilda Hulme, the mother of Juliet Hulme, one of the girls convicted

\footnotetext{
57 'Plan To Prevent Increases In Divorces'. EP, 3 December 1947. Jane Simpson has explored in depth the links between Marriage Guidance and the National Council of Churches (NCC). The NCC was founded in New Zealand in 1941 and was an umbrella organisation of Protestant denominations. See Jane M.R. Simpson. 'Liberal Christianity and the Changing Role of Women in New Zealand Society: A Study of the National Council of Churches and the League of Mothers, 1939 to 1959'. PhD thesis, University of Otago, 1992, 99-183.

${ }^{58}$ Mears was an English doctor who lived in Christchurch between 1946 and 1956, when she returned to England. She was also involved with the Family Planning Association. She had an unhappy marriage and her husband petitioned for divorce in Christchurch in 1958, but this file has not been accessed as it is restricted until 2018. See Kenneth Patrick Geddes Mears v Eleanor Cowie Mears, CAHX, 3007, CH208, Box201, D132/1958, ANZ-C. Also see, Paul Vaughan. 'Mears, Eleanor Cowie (1917-1992)', Oxford Dictionary of National Biography, 2004. URL: http://www.oxforddnb.com/view/article/47178.

${ }^{59}$ Daly, 6; and 'Marriage Guidance. Formation of Council'. EP, 20 February 1948.

${ }^{60}$ Brenda L. Stedman. 'The Origins and Development of the Dunedin Marriage Guidance Council, 1948 1970'. BA(Hons) essay, University of Otago, 1988, 28.

${ }^{61}$ For example see, Evans; Tara Gimpel. 'Marriage, Singleness and Sexuality'. BA(Hons) research essay, University of Otago, 2009, 14-25.

${ }^{62}$ Stedman, 36.

${ }^{63}$ Ibid., 54.
} 
of the murder, worked as a counsellor and served as vice-president of the Christchurch branch of the Marriage Guidance Council until her resignation in May 1954 (just prior to the murder in June 1954). There was much controversy over her daughter's actions, and it was also revealed that Hilda Hulme had been having an affair with a man whom she had met in her role as a counsellor at the Marriage Guidance Council. ${ }^{64}$ The national headquarters of Marriage Guidance was moved from Christchurch to Auckland in 1958, following this episode. ${ }^{65}$ One of the reasons why this case was so shocking was that it was believed that bad homes bred bad children, and on the face of it the Hulme family did not fit into the category of a 'bad family' - Juliet's father was the rector of Canterbury College and a distinguished physicist. ${ }^{66}$ Once Hilda Hulme's personal relationship was revealed, however, this was used in part to explain the situation. It also highlighted the need for more screening of potential guidance counsellors as well as the need for more training. This, however, was a taint that raised questions about Marriage Guidance.

The Parker-Hulme murder and the behaviour of some youths in Lower Hutt resulted in the creation of the Mazengarb enquiry in 1954. By the mid-1950s the 'teenager' had emerged as a distinct social category with its own distinct fashion and music, and there were many concerns about the behaviour of this 'new' social group. ${ }^{67}$ The 78 page report resulting from the Mazengarb enquiry was mailed to every household receiving the family benefit. ${ }^{68}$ It stated,

a child living in an abnormal family environment, whether that abnormality arises from the birth of the child or the maladjusted personality of a parent, is the type of child which may later seek compensation in irregular sexual behaviour. But the child who, during its early years, lives in an environment where it feels secure, loved, and accepted is not likely to become a deviant. ${ }^{69}$

\footnotetext{
${ }^{64}$ Julie Glamuzina and Alison J. Laurie. Parker \& Hulme. A Lesbian View. Auckland, 1991, 56-58.

65 Daly, 10.

${ }^{66}$ Pauline Parker was the other girl convicted of murder, and it was her mother, Honora who was killed. Unlike Hulme, Parker's family were working class. Pauline was known as Pauline Rieper, but after the murder it emerged that her parents were not actually married and so she was charged under her mother's maiden name. Honora had not married Herbert Rieper, Pauline's father, despite living with him for 23 years, as he had already been married, and never obtained a divorce from his first wife. Honora and Herbert, however, lived together as husband and wife, and if it had not been for the murder, it is very likely no one would have discovered they were not legally married. Glamuzina and Laurie, 36-37. Also, Simpson, 15961.

${ }^{67}$ Redmer Yska. All Shook Up. The Flash Bodgie and the Rise of the New Zealand Teenager in the Fifties. Auckland: 1993; Jon Stratton. 'Bodgies and Widgies - Youth Culture in the 1950s'. Journal of Australian Studies 8, no.15 (1984): 10-24.

${ }^{68}$ McClure, 150-51.

${ }^{69}$ Report of the Special Committee on Moral Delinquency in Children and Adolescents. Wellington: Govt Printer, 1954, 33.
} 
The first example of a bad family environment listed was emotional disturbances arising out of a divorce, separation or remarriage. Mazengarb also claimed that 'sexual immorality among young people arises, in part, from the fact that mothers are frequently absent from their homes at times when their children need their care and guidance' ${ }^{70}$ In the 1950s, married women in New Zealand worked outside the home less than their counterparts in Britain and the United States, but this did not reduce his concerns, nor the popularity of his message. Dr Mazengarb was often invited to share his views on child rearing and families after the publishing of his report, and in June 1957 he told the Manakau branch of the New Zealand Educational Institute that, 'there was less to fear from the consequences of splitting the atom than there was from the consequences to society of splitting the family'. ${ }^{71}$

Marriage Guidance Councils were one part of a wider movement which provided support to couples. In Wellington there was the Family Guidance Council, which was affiliated with the Marriage Guidance Councils and the Society for the Protection of Women and Children. At a talk to the Wellington branch of the Society for Protection of Women and Children at Victoria University College in 1951, Brenda Stubbs, a lecturer in social science said 'I feel I must take the part of the fathers a little. I know Professor Marsh [the professor of social science at the university] has teased you a little already on the name of your society and I'm reminded of the catchword of a recent conference dealing with domestic matters - "are fathers necessary?" "You can't divorce the child from either parent. He is a reflection of how the mother and father work out their relationship. If the mother needs help and advice, so does the father. In helping the maladjusted child, it is possible often to help a marital situation.",72 The Society changed its name in 1955 to the Society for the Protection of Home and Family, as a result of criticisms like Stubb's. ${ }^{73}$

\footnotetext{
${ }^{70}$ Ibid., 35. For further details of the report and general concerns about 'juvenile delinquency' in the 1950s see Bronwyn Dalley. Family Matters. Child Welfare in Twentieth-Century New Zealand. Auckland: 1998, 178-95; Claire Gooder. 'A History of Sex Education in New Zealand, 1939-1985'. PhD thesis, University of Auckland, 2010, 88-113; Chris Brickell, 'Sexuality, Morality and Society', in The New Oxford History of New Zealand, ed. Giselle Byrnes. Melbourne: 2009, 474-76; Margie Thompson. 'Moral Panic in the Hutt Valley. The Mazengarb Inquiry of 1954', in Standing in the Sunshine. A History of New Zealand Women since they Won the Vote, ed. Sandra Coney. Auckland: 1993, 174-75; Simpson, 161-68.

71 'Split Family Worse Than Split Atom'. EP, 19 June 1957.

72 'One-Sided Help or "Are Fathers Necessary?", EP, 30 October 1951.

${ }^{73}$ Tennant, 136. For a history of the Auckland branch over this period see, Raewyn Dalziel. Focus on the Family. The Auckland Home and Family Society, 1893-1993. Auckland: 1993, 44-53.
} 
The Mace visit in 1956 also helped build support for the movement. ${ }^{74}$ David Mace had written a number of books on Marriage Guidance and was considered an expert in the field. ${ }^{75} \mathrm{He}$ had a $\mathrm{PhD}$ in sociology and had previously been a Methodist minister for ten years. $^{76}$ Vera Mace lacked formal qualifications related to Marriage Guidance, but she was considered an expert by virtue of being married. She spoke to several audiences at the Wesley Church in Taranaki Street, Wellington. At a United Women's meeting she claimed 'learning to love is a scientific imperative of our time'. ${ }^{77}$ She outlined the many roles a wife and mother had in the family, and claimed that these various duties were so important and fundamental that she questioned whether married women 'could be spared to go out to work' ${ }^{78}$ She continued with this message at a youth rally at the same church and also addressed the 'problem' of pre-marital sex. She expressed shock that twenty per cent of first births in New Zealand had been conceived outside of marriage, and that New Zealand had such a high septic abortion rate, and said that 'experimentation with sex before marriage could not possibly be a good thing, ${ }^{79}$ The Maces highlighted issues such as the need for careful consideration prior to marriage, the importance of the role of married women as homemakers (and the 'problems' with married women in paid work), and the nature of marriage counselling. He claimed, '[t]he stage at which a counsellor should be called in was after a couple had reached a dead end, but before one of the partners had given up hope of a solution being reached. Little could be done after this chronic phase had been reached, ${ }^{80} \mathrm{He}$ also assured his New Zealand audiences that, “There probably isn't a country in the world where the opportunities are better for developing and maintaining family life"،. 81

The Justice Department's support helped to reinvigorate Marriage Guidance in the late 1950s. The Department's support was based on the belief about the connections between criminality and broken homes. Sam Barnett, the Secretary for Justice, explained the reason for supporting the programme, saying, 'No research was required to realise that a

\footnotetext{
${ }_{75}^{74}$ For an overview of the Mace visit see Simpson, 169-72.

${ }^{75}$ Mace's works included, Marriage Crisis. London: 1948; Marriage. The Art of Lasting Happiness. London: 1952; Whom God Hath Joined. A Book of Christian Marriage. London: 1953; Success in Marriage. London: 1958; Youth Looks Toward Marriage. London: 1958.

76 'Expert Thinks NZ Fortunate. Everything In Favour Of Happy Marriages'. EP, 16 July 1956.

77 'Importance of Personal Family Relationships'. EP, 19 July 1956.

78 Ibid.

79 'Marriage, Guidance Expert Addresses Youth'. EP, 17 July 1956.

80 'Both Partners Of Marriage Must Co-operate'. EP, 18 July 1956.

81 'N.Z. Divorce Rate Not So Good'. EP, 17 July 1956. As previously shown in Chapter Two, New Zealand had the highest divorce rate in the Commonwealth until at least 1950.
} 
large proportion of convicted criminals came from bad, broken, or unsatisfactory homes and the Department was concerned in the home as the source of crime'. ${ }^{82}$ Although the Justice Department provided Marriage Guidance with an annual grant, it remained separate to the department as officials believed it inappropriate 'for the state to develop a fully fledged counselling service to deal with the most intimate of relationships' ${ }^{83}$ Reverend Clements, who had accompanied the Maces on their tour of New Zealand and who was the senior prison chaplain, received an appointment as adviser in marriage guidance to help prevent New Zealanders from becoming criminals through creating happy family life. ${ }^{84}$ As well there was concern with the cost of supporting deserted wives and children and so it was believed that Marriage Guidance would pay for itself by 'saving' some marriages.

By 1960 New Zealand had become, if not completely, then predominantly, a secular society. Marriage still held a central position in this secular society, however, and most still regarded it, at least in part, as a relationship sanctioned by the church. People were still going to church, but were looking for marriage and family advice elsewhere. On the other hand, individual church members were involved in organisations such as Marriage Guidance that were not specifically religious but in which religious beliefs played an important role. At the same time, most weddings were still conducted in churches. There was an emphasis on a constant need for self-improvement and a growing emphasis on the need for those who were unable to help themselves with the assistance of guidance books and magazine articles written by 'experts' to seek out personal assistance from professional counsellors or psychologists.

The founding of Marriage Guidance Councils in New Zealand was a direct response to the increasing numbers of divorces during and after World War II and the Councils in New Zealand were strongly influenced by their British counterparts. There was a growing emphasis on the husband-wife relationship being the central relationship in people's lives and a relationship that should provide emotional, physical and sexual fulfilment. This was in part a result of demographic changes whereby people married and had their children at a comparatively young age, but were living for longer than their parents and grandparents.

\footnotetext{
82 'Urgent Need in Field of Married Life'. EP, 30 August 1958.

${ }^{83}$ Tennant, 138.

84 'To Reduce Discordance. Marriage Guidance Adviser Appointed'. EP, 7 July 1959.
} 
This resulted in a smaller proportion of married life being dedicated to child-rearing, and instead the focus was on the relationship between husbands and wives. On the other hand, there was the belief that marriages needed to be maintained for the sake of children and the stability of society. Marriage Guidance was an attempt to provide professional and expert advice to people considering getting married, those who had marital problems, or those who were trying to end their marriages in the least acrimonious manner possible, although the Marriage Guidance Council did not draw attention to this final group. Marriage Guidance was an indication that staying married could not be assumed and that marriage had to be worked at. Its existence also suggests that there was a midway point between being married and legal separated or divorce, reflecting the unloosening of marriage. While the assistance provided by Marriage Guidance was not taken up by large numbers of New Zealanders in the late 1940s and during the 1950s, the funding provided by the Justice Department at the end of that decade assisted the organisation that became increasingly influential during the 1960s when the divorce rate began to increase more steadily again.

The span of this study, c.1890s - c.1950s, is one in which the overall trend was towards an increasing incidence of divorce. Divorce, while still the fate of a minority of marriages at the end of the period, was part of a deeper set of changes in marriage and family relationships. The increasing divorce rate provides evidence of New Zealanders' desire to have their personal relationships conform to their legal relationships - those who did not get divorced could not legitimise future unions, and children of these unions. With the growth of the welfare state, in particular, there were increasing financial benefits to being able to conform to the law.

While many of the patterns detected in this study mirror those identified in other western, Protestant, common-law jurisdictions, the New Zealand experience was unique in some respects. Divorcing couples in New Zealand more frequently belonged to the working class than litigants in Canada or England. This suggests a more accessible justice system and a greater desire of working class couples to regularise their relationships in contrast to the English pattern where many working class couples formed 'irregular' unions. The reluctance of middle class and wealthier New Zealanders to divorce shows a concern with 
a loss of property and wealth, especially for wives, and the threat to social status and respectability. Except for those seeking to rise into the ranks of the respectable middle class this did not affect working class couples to the same extent. Because the courts and the law made it relatively available even to those on lower incomes, New Zealanders divorced at comparatively high rates compared to other parts of the Anglo world, but lagged behind the United States.

Divorce files captured people's lives in brief or longer segments - which were often very emotionally wrought, confrontational and upsetting. The evidence contained in divorce files also challenges the notion of a puritanical, restrictive society dominated by the 'wowsers' which the editor of Truth claimed to have invented as a term of contempt. The incidence of extra-marital births, 'shotgun' marriages and the depiction of family life reveal a more permissive pattern of interaction. This challenges Belich's portrayal of New Zealand as a tight society during this period, unless one restricts the 'tight society' to middle class ideology which working classes undermined or challenged. Divorce records provide ample signs of what Caroline Daley has termed 'pleasure-seeking', especially in regards to adultery as a ground for divorce. The divorce records show, in fact, a people pulled between the temptations of pleasure-seeking and the rewards of respectability. These records thus complicate the narrative of stable family life in New Zealand during the first half of the twentieth century.

Uniquely in the British world, the New Zealand Parliament provided a form of "no fault divorce' from 1920, with the introduction of mutual separation of three years or more as a ground for divorce. This law allowed couples to avoid the painful scrutiny, the embarrassment, the gossip, and the ostracism which might be visited upon the couple who used other grounds to petition for divorce. New Zealand pioneered divorce liberalisation, but also did not rush to remove all notions of fault from the grounds for divorce. However, the law in letter remained fault-based throughout this period, and it is probably because of the existence of this comparatively lenient ground for divorce that New Zealand did not make irreconcilable differences the only ground for divorce until 1980 - comparatively late in the western context. While separation of three years or more quickly became the most common ground for litigants to petition for divorce, some couples did not take up this option suggesting that publicity still played an important part of social control and punishment. 
The divorce records where the petitioner selected another ground for divorce, particularly adultery, catered to the desire to punish people who deviated from the straight and narrow, condemning those who did not conform to the notion of respectability, morality and successful marriages. The tactics of surveillance, the testimony of vindictive spouses, the open court proceedings, and extensive newspaper coverage catered to the punitive drive in New Zealand culture which reinforced or supplanted the religious strictures against sin. Newspapers played an important role in deterring people from divorcing, and especially from having a particularly volatile and contested case, which papers such as Truth turned into profitable copy. It was only in 1958 that Parliament changed the law, 32 years after a similar law was passed in England, reducing the ability of editors and newspaper proprietors to publish salacious details from cases.

Newspapers played a complex role in relation to divorce as this thesis has demonstrated. Their coverage created a sense of concern about the increasing incidence of divorce, while serving as a deterrent to those desiring to maintain their reputations for respectability. The performance and display of various truths in support of claims for divorce were accentuated by newspaper reporting, and coverage of divorce cases provided an opportunity for the media and the public to debate gender norms and expectations using the personal relationships of their fellow citizens. At the same time, by publicising divorce, newspapers helped normalise it by making it appear a common action. As the number of divorces increased, moreover, newspapers covered proportionally fewer and fewer cases, so most people escaped publicity.

This thesis has demonstrated that New Zealand showed the same clear and strong relationship between war and divorce which occurred in other nations at war. The increasing rate of divorce after World War I, and during and after World War II confirms international trends even though these most often involved couples on a home front very distant from the fighting. During World War I very few married men served on the front lines. While there was an increase in married women's employment during both wars, overall their employment rate was much lower than in other countries. Clearly, it is not adequate to account for the increase in divorce by pointing to husbands serving overseas or wives being more economically independent. While these were contributing factors, especially during World War II, the situation was far more complex, evidenced especially 
by the persistence of higher divorce rates after the war. Fundamental changes occurred in individual attitudes and social practices during wartime, which served to accelerate changes already underway in the prewar years while giving those changes sufficient momentum to continue in the postwar period. The fluidity of wartime thus decreased the ability of spouses, parents, neighbours, churches and communities to prevent individuals from seeking their own self-fulfilment, irrespective of the claims of matrimony or public opinion.

The divorce files also reveal the greater willingness to 'talk about sex' as Janice Irvine has discussed during the first half of the twentieth century. ${ }^{85}$ At the beginning of the period litigants spoke of 'misbehaviour' or used other euphemisms, but by the end of the period people gave more detailed descriptions speaking about 'intercourse' or franker descriptions. The popularisation of Freud provided a language for people to talk about sex, and the availability of works such as Stopes' Married Love and the work of Havelock Ellis changed the way people thought about sex, female desire and the role sex should play in a marriage. The awareness of the power of emotions, and the potential for desire to be a motivating force increased. Married people became more willing to leave their spouses if their emotional and sexual needs were not being met, particularly during and immediately after World War II. Adultery, too, became more normalised, in part due to the exposure of divorce cases in the media, resulting in a decrease in the shame of being cuckolded. Husbands still displayed less toleration for adultery than wives, indicating a lingering double standard despite the change in the law in 1898.

Divorce still carried a degree of disapprobation as demonstrated in James K. Baxter's 1966 poem, 'Divorcee' about a divorced woman who turns to prostitution to support herself. ${ }^{86}$ By the end of this study wives enjoyed more opportunities to breach the marital bond and became more active in forming other relationships or deserting their partners as men had often done. This in turn resulted in proportionally more husbands petitioning for divorce and wives being subjected to 'punishment' by the judiciary, either by restricting access to their children or withholding maintenance. Throughout the period husbands had many advantages over wives. As the main income earners men had a wider variety of employment opportunities. While husbands were almost always in a more advantageous

\footnotetext{
${ }^{85}$ Janice M. Irvine. Talk About Sex. The Battles over Sex Education in the United States. Berkeley, 2002.

${ }^{86}$ James K. Baxter. 'Divorcee'. James K. Baxter, Poems. ed. Sam Hunt. Auckland: 2009, 73.
} 
position than their wives the balance of power did alter, with wives assuming more authority and economic independence through paid work, or at least the potential to find paid employment, along with the courts awarding maintenance for wives and their children.

The establishment of Marriage Guidance in New Zealand in 1948 responded to the increasing divorce rate, particularly during World War II. It reflected the increasingly prevalent view that marriages required expert reinforcement to enable the couples to find mutual satisfaction. While both partners were expected to 'work' on their marriages, it was seen primarily as the responsibility of wives to maintain the quality of the marital relationship. While modernity has been associated with the privileging of individual happiness, there was still a great emphasis on families (primarily nuclear families) during the late 1940s and 1950s. Advice against rash marriages provided a way to reduce the likelihood of problems later. Concern about the impact of 'broken homes' on children received widespread publicity and the welfare of children was a primary matter for those who divorced.

Divorce offers a mirror into many important and often hidden aspects of New Zealand culture and history, particularly its growing secularisation, the turning of marriage from a sacrament into a contract, the growth of individual rights, sexualisation, surveillance, the role of the press, pleasure seeking in conflict with constraints, and the desire for respectability at odds with the desire for personal fulfilment. The wives and husbands who dissolved their marriages through divorce represent a significant group of New Zealanders who responded to the changes which occurred over the first half of the twentieth century by deciding to end unsatisfying relationships. Individual histories carry their own drama and will conform or deviate to the broad picture charted in these pages. The growing numbers who made this decision shows an overall trend towards increasing self-reliance and a rejection of traditional constraints.

This thesis has provided a picture of larger trends over a long period, from the $1890 \mathrm{~s}$ when Queen Victoria was still on the throne, to a 'new' Elizabethan era, the 1950s. In the decades following, the 1960s and 1970s, marriage and gender relations were to be challenged even more radically. But these changes did not proceed from a static or stable base. Much had already changed between the era of Kate Sheppard and that of Hilda Ross. 


\section{Appendix}

Column A - Husband's Occupation at Marriage

Column B - Husband's Occupation at Divorce

Column C - Husband's Father's Occupation

Column D - Wife's Father's Occupation

Column E - Co-Respondent's Occupation

Summary of Male Occupations

\begin{tabular}{|l|c|c|c|c|c|}
\hline & A & B & C & D & E \\
\hline Large Employers/Managers (01) & 10 & 24 & 16 & 8 & 4 \\
\hline Professionals (02) & 45 & 40 & 65 & 51 & 7 \\
\hline Semi-Professionals (03) & 92 & 68 & 82 & 73 & 10 \\
\hline Petty Proprietors (04) & 99 & 99 & 190 & 164 & 16 \\
\hline Petty Officials (05) & 84 & 113 & 95 & 93 & 6 \\
\hline White-Collars (06) & 213 & 186 & 124 & 115 & 23 \\
\hline Skilled (07) & 597 & 481 & 575 & 554 & 52 \\
\hline Semi-Skilled (08) & 166 & 178 & 84 & 99 & 45 \\
\hline Unskilled (09) & 293 & 297 & 230 & 290 & 81 \\
\hline Rural Proprietors (15) & 88 & 61 & 216 & 208 & 11 \\
\hline Rural Occupations (16) & 31 & 11 & 20 & 24 & 6 \\
\hline Students (17) & 0 & 2 & 0 & 0 & 0 \\
\hline Military (officers) (18) & 10 & 7 & 8 & 6 & 1 \\
\hline Military (enlisted and rank undefined) (19) & 89 & 127 & 7 & 9 & 21 \\
\hline Undefined (20) & 10 & 13 & 47 & 59 & 4 \\
\hline TOTAL & $\mathbf{1 8 2 7}$ & $\mathbf{1 7 0 7}$ & $\mathbf{1 7 5 9}$ & $\mathbf{1 7 5 3}$ & $\mathbf{2 8 7}$ \\
\hline
\end{tabular}

\section{$\underline{\text { Large Employers/Managers (01) }}$}

\begin{tabular}{|l|l|l|l|l|l|}
\hline Banker & & & 2 & 1 & \\
\hline Company Director & & 3 & 2 & & 1 \\
\hline Company Manager & 8 & 17 & 9 & 6 & 2 \\
\hline General Manager & & 1 & & & \\
\hline $\begin{array}{l}\text { General Manager - Wellington Harbour } \\
\text { Board }\end{array}$ & & 1 & & & \\
\hline Hotel Manager & 2 & 2 & & 1 & 1 \\
\hline Managing Director & & & 2 & & \\
\hline Motor Car Distributor & & & 1 & & \\
\hline
\end{tabular}

\section{$\underline{\text { Professionals (02) }}$}

\begin{tabular}{|l|l|l|l|l|l|}
\hline Accountant & 20 & 17 & 22 & 20 & 2 \\
\hline Architect & 3 & 2 & 8 & 2 & 1 \\
\hline Auditor & 1 & & 1 & & \\
\hline Barrister & & & 2 & 2 & \\
\hline Brigadier General - Director of Postal & & & 1 & & \\
\hline
\end{tabular}




\begin{tabular}{|l|l|l|l|l|l|}
\hline Services & & & & & \\
\hline Civil Engineer & 2 & & 5 & 4 & \\
\hline Company Secretary & & 1 & 1 & 1 & 2 \\
\hline Dentist & 4 & 5 & 3 & 5 & 1 \\
\hline Director - Meteorological Office & & & 1 & & \\
\hline Financial Agent & & & & 1 & \\
\hline Lawyer & 3 & 6 & 7 & 5 & \\
\hline Medical Practitioner & & & 1 & & \\
\hline Member of Parliament & & & & 1 & \\
\hline Minister of the Crown & 1 & & 1 & & \\
\hline Member of Legislative Council & & & 1 & & \\
\hline Naturalist & & 1 & 1 & & \\
\hline Naval Engineer & & & 1 & & \\
\hline Officer - Coast Guards & & 1 & & & \\
\hline Optical Specialist & & & 1 & & \\
\hline Professor & 1 & 1 & & & \\
\hline Quantity Surveyor & & & 1 & & \\
\hline Resident Magistrate & & & 1 & & \\
\hline Share Broker & 9 & 6 & 4 & 2 & 1 \\
\hline Solicitor & & & 1 & 1 & \\
\hline Stock Broker & & & 1 & 1 & \\
\hline Surgeon & 1 & & & & \\
\hline Treasurer - Wellington Harbour Board & & & & 3 & \\
\hline Vet Surgeon & & & \\
\hline
\end{tabular}

\section{$\underline{\text { Semi-Professionals (03) }}$}

\begin{tabular}{|l|l|l|l|l|l|}
\hline Actor & 3 & 2 & & 1 & \\
\hline Actuary & & & 1 & & \\
\hline Advertisement Writer & 2 & & & & \\
\hline Airforce Pilot & 1 & & & & \\
\hline Artist & 1 & 1 & 2 & 3 & \\
\hline Auctioneer & 1 & 1 & 2 & 1 & 1 \\
\hline Author & & & 1 & & \\
\hline Captain - Mercantile Marines & & & 2 & 1 & \\
\hline Chiropodist & & 1 & & & \\
\hline Clergyman & 1 & & 3 & 1 & \\
\hline Clerk in Holy Orders & 1 & & 1 & & \\
\hline Comedian & 2 & & & 1 & \\
\hline County Clerk & 1 & & & & \\
\hline Designer & 1 & 1 & & & \\
\hline Doctor of Divinity & & & 1 & & \\
\hline Draftsman & 1 & & & & \\
\hline Dramatic Artist & & & & 1 & \\
\hline Draughtsman & 4 & 2 & & 2 & \\
\hline Editor & & 1 & & & \\
\hline Electrical Engineer & 8 & 5 & 2 & 2 & 2 \\
\hline Flying Instructor & 1 & & & & \\
\hline
\end{tabular}




\begin{tabular}{|c|c|c|c|c|c|}
\hline Government Valuer & & & & 1 & \\
\hline Industrial Chemist & & 1 & & & \\
\hline Insurance Valuer & & & & 1 & \\
\hline Journalist & 7 & 5 & 8 & 5 & \\
\hline Law Reporter & & 1 & & & \\
\hline Leadlight Artist & 1 & & & 1 & \\
\hline Librarian & 1 & 1 & 1 & & \\
\hline Manager & 4 & 6 & 11 & 6 & \\
\hline Marine Engineer & 2 & 2 & 3 & 2 & \\
\hline Master Mariner & 1 & 2 & 10 & 10 & \\
\hline Mechanical Engineer & 5 & 2 & 1 & 3 & \\
\hline Mercantile Marine Officer & 1 & & 1 & & \\
\hline Minister of Religion & & & 3 & 1 & \\
\hline Musician & 8 & 6 & 4 & 4 & 2 \\
\hline Navy Pilot & 1 & & & & \\
\hline Oculist & 1 & & & & \\
\hline Officer - Merchant Service & 1 & 1 & & & \\
\hline Optician's Assistant & & 1 & & & \\
\hline Pelt Classer & & & 2 & & \\
\hline Photographer & 5 & 5 & 1 & 2 & 3 \\
\hline Photo Process Engraver & 2 & 1 & & & \\
\hline Pianist & & & & 1 & \\
\hline Pilot & & & 2 & 1 & \\
\hline Police Inspector & & & 1 & 1 & \\
\hline Process Engraver & 1 & 1 & & & \\
\hline Publisher & 2 & 1 & & 1 & \\
\hline Radio Broadcasting Engineer & 2 & 1 & & & \\
\hline Reporter & 1 & & & & \\
\hline Schoolmaster & 2 & 2 & 6 & 4 & \\
\hline School Teacher & & 2 & 3 & 3 & \\
\hline Shoe Artist & 1 & & & & \\
\hline Singing Teacher & & 1 & & & \\
\hline Surveyor & 4 & 1 & 4 & 4 & 1 \\
\hline Teacher & 3 & 2 & & 2 & \\
\hline Theatre Manager & & 2 & & 2 & \\
\hline Theatrical Manager & 1 & 3 & & & \\
\hline Tragedian & & & & 1 & \\
\hline Wesleyan Minister & & & 1 & & \\
\hline Wool Broker & 1 & & 1 & & \\
\hline Wool Buyer & & & 1 & & 1 \\
\hline Wool Classer & 6 & 4 & 3 & 4 & \\
\hline
\end{tabular}

\section{Petty Proprietors (04)}

\begin{tabular}{|l|l|l|l|l|l|}
\hline Bank Manager & & & 3 & 1 & \\
\hline Billiard Table Manufacturer & & & & 1 & \\
\hline Blind and Curtain Manufacturer & & 1 & & & \\
\hline Boardinghouse Keeper & 1 & & & & \\
\hline
\end{tabular}




\begin{tabular}{|c|c|c|c|c|c|}
\hline Boardinghouse Proprietor & & 2 & 1 & & \\
\hline Book Manufacturer & & & 1 & & \\
\hline Bookseller & 2 & 1 & 1 & & \\
\hline Boot Importer & 1 & 1 & 1 & & \\
\hline Boot Manufacturer & & & 3 & 1 & \\
\hline Brass Founder & & & & 1 & \\
\hline Building Contractor & & & 3 & & \\
\hline Bush Contractor & 1 & & 1 & & \\
\hline Cab Proprietor & 2 & 2 & 1 & & \\
\hline Café Proprietor & 1 & & & 1 & \\
\hline Car Dealer & & & & 1 & \\
\hline Cartage Contractor & 1 & 1 & & & \\
\hline Cattle Dealer & & & 1 & 1 & \\
\hline Chemist & 7 & 6 & 3 & 5 & \\
\hline Coach Proprietor & & & & 1 & \\
\hline Coal Dealer & & & & 1 & \\
\hline Coal Merchant & & & 1 & 3 & \\
\hline Coal Merchant and Contractor & & 1 & & & \\
\hline Commissioner & & & 1 & 1 & \\
\hline Contractor & 7 & 10 & 21 & 31 & 2 \\
\hline Cordial Manufacturer & 1 & & 2 & & \\
\hline Cork Manufacturer & & & 2 & & \\
\hline Corn Merchant & 1 & & 2 & 1 & \\
\hline Costume Manufacturer & & 1 & & & \\
\hline Cycle Dealer & & & & 1 & 1 \\
\hline Dairyman & & 2 & 1 & 5 & \\
\hline Dairy Produce Agent & 1 & & & & \\
\hline Dog Breeder & & 1 & & & \\
\hline Door Manufacturer & & 1 & & & \\
\hline Draper & 7 & 6 & 8 & 8 & \\
\hline Fish Merchant & & & 1 & & \\
\hline Fishmonger & & & 1 & 1 & \\
\hline Flax Broker & & & & 1 & \\
\hline Fruiterer & 4 & 3 & 5 & 1 & 1 \\
\hline Furniture Manufacturer & & & 1 & & \\
\hline Garage Proprietor & 2 & 3 & 4 & 1 & 1 \\
\hline General Merchant & & & 1 & 1 & \\
\hline General Trader & & & 1 & & \\
\hline Gold Miner & & & & 1 & \\
\hline Grain Merchant & 1 & & & 1 & \\
\hline Greengrocer & & 1 & 1 & & 1 \\
\hline Grocer & 13 & 5 & 10 & 9 & 1 \\
\hline Guest House Proprietor & & 1 & & & \\
\hline Hawker & & 1 & & & \\
\hline Herbalist & & & & 1 & 1 \\
\hline Horse Dealer & 1 & & 3 & & \\
\hline Horse Owner & & & 1 & & \\
\hline Hosiery Manufacturer & & & 1 & & \\
\hline
\end{tabular}




\begin{tabular}{|c|c|c|c|c|c|}
\hline Hotel Keeper & 2 & 5 & 19 & 24 & 2 \\
\hline Hotel Licensee & 1 & & & 1 & \\
\hline Hotel Proprietor & & & 5 & 1 & \\
\hline Hulk Keeper & & & & 1 & \\
\hline Inn Keeper & & & 1 & & \\
\hline Insurance Manager & & & 1 & & \\
\hline Ironmonger & 3 & 1 & 3 & 2 & \\
\hline Landscape Gardener & 1 & 1 & 1 & & \\
\hline Launch Owner & 1 & & & & \\
\hline Laundry Proprietor & & & 2 & & \\
\hline Leather Merchant & & 2 & & & \\
\hline Licensed Victualler & & & 1 & & \\
\hline Livery Stable Keeper & & & 1 & & \\
\hline Manufacturer & 4 & 3 & 4 & 6 & \\
\hline Market Gardener & 1 & & & 3 & \\
\hline Master Baker & & & 1 & & \\
\hline Master Upholsterer & 1 & & 1 & & \\
\hline Mercer & 2 & & 1 & & \\
\hline Merchant & 6 & 8 & 22 & 16 & 1 \\
\hline Mining Agent & & & 1 & & \\
\hline Mining Expert & & & 1 & & \\
\hline Money Lender & & & & & 1 \\
\hline Motor Car Proprietor & 2 & & & & \\
\hline Motor Dealer & & 2 & 1 & 1 & \\
\hline Newsagent & & & & 1 & \\
\hline Newspaper Proprietor & & 1 & & & \\
\hline Paint Manufacturer & 1 & & & & \\
\hline Peddler & & & 1 & 1 & \\
\hline Petrol Station Proprietor & & 1 & & & \\
\hline Piano Forte Dealer & & & 1 & & \\
\hline Produce Merchant & & & & 1 & \\
\hline Proprietor & 1 & & 2 & 1 & \\
\hline Provisions Merchant & & & & 1 & 1 \\
\hline Publican & & 4 & 6 & 2 & \\
\hline Radio Dealer & 1 & & & & \\
\hline Restaurateur & 1 & 2 & & 1 & \\
\hline Restaurant Keeper & & 3 & 2 & & \\
\hline Restaurant Proprietor & 1 & & & & 1 \\
\hline Second Hand Dealer & & 1 & & & \\
\hline Ship Owner & & 1 & 2 & & \\
\hline Shoe Manufacturer & & 1 & & & \\
\hline Shop Keeper & 1 & & 1 & 1 & \\
\hline Shop Owner & 1 & & 3 & 1 & \\
\hline Show Proprietor & & & & 1 & \\
\hline Soap Manufacturer & & & 1 & & \\
\hline Stock Agent & 1 & & & & \\
\hline Storekeeper & 3 & 4 & 7 & 9 & 2 \\
\hline Surgical Supply Business Owner & & & 1 & & \\
\hline
\end{tabular}




\begin{tabular}{|l|l|l|l|l|l|}
\hline Taxi Proprietor & 8 & 7 & 3 & 2 & \\
\hline Tea Dealer & & & & 1 & \\
\hline Theatrical Proprietor & & & 2 & & \\
\hline Timber Merchant & 1 & & & 1 & \\
\hline Tobacconist & & 2 & 2 & 2 & \\
\hline Vendor & & & 1 & & \\
\hline Wine Merchant & 1 & & 2 & 1 & \\
\hline Wood Merchant & & & & 1 & \\
\hline
\end{tabular}

\section{Petty Officials (05)}

\begin{tabular}{|c|c|c|c|c|c|}
\hline Air Ministry & & & & 1 & \\
\hline Armed Constabulary & 1 & & & & \\
\hline Assistant Factory Manager & & 1 & & & \\
\hline Attendant & & & 1 & 2 & \\
\hline Attendant at Mental Hospital & 1 & & & & \\
\hline Audit Inspector & & 1 & & & \\
\hline Assistant Manager & & 1 & & & \\
\hline Bailiff & & 1 & & & \\
\hline Borough Overseer & & & & 1 & \\
\hline Branch Manager & 2 & & & & \\
\hline Business Manager & & & 1 & & \\
\hline Chief Steward & & 1 & & & \\
\hline City Council Employee & & 5 & & 1 & \\
\hline City Council Foreman & & & 1 & & \\
\hline Civil Servant & 29 & 52 & 28 & 31 & 1 \\
\hline Club Manager & 1 & & & & \\
\hline Coast Guard & & & & 1 & \\
\hline Council Employee & & & 1 & 2 & 1 \\
\hline County Overseer & & & 1 & & \\
\hline Court Assessor & & & & 1 & \\
\hline Court Bailiff & & & 1 & & \\
\hline Creamery Manager & 1 & & & & \\
\hline Custodian & 1 & & 3 & 2 & \\
\hline Customs and Forwarding Agent & & & 1 & 1 & \\
\hline Customs Officer & 1 & 1 & 3 & & \\
\hline Dairy Factory Manager & & 1 & & & \\
\hline Department Manager & 3 & 2 & 1 & & \\
\hline Dock Manager & & & & 1 & \\
\hline Drainage Inspector & & & 1 & & \\
\hline Drainage Overseer & & 1 & & & \\
\hline Drapery Manager & & & & 1 & \\
\hline Electrical Lines Inspector & & 1 & & & \\
\hline Factory Inspector & & & & 1 & \\
\hline Factory Manager & & 2 & 2 & & \\
\hline Film Manager & 1 & & & & \\
\hline Gamekeeper & & & 2 & 1 & \\
\hline Gaoler & & & 1 & & \\
\hline
\end{tabular}




\begin{tabular}{|c|c|c|c|c|c|}
\hline Garage Manager & & 1 & & & \\
\hline Garden Overseer & & & 1 & & \\
\hline Government Inspector & & & & 1 & \\
\hline Government Messenger & & 1 & & 2 & 1 \\
\hline Government Official & & 1 & 1 & & \\
\hline Government Rabbiter & 1 & & & & \\
\hline Guard & & 1 & 1 & & \\
\hline Harbour Board Employee & 2 & 8 & 2 & 1 & \\
\hline Home Service Guardsman & & & & 1 & \\
\hline Hospital Attendant & 3 & 1 & & & \\
\hline Inspector & & 1 & 1 & 3 & \\
\hline Insurance Inspector & 1 & 1 & & & \\
\hline Insurance Superintendent & & 1 & 1 & & \\
\hline Irish Constabulary & & & & 1 & \\
\hline Job Master & & & 1 & & \\
\hline Keeper & & & 1 & & \\
\hline London City Council Employee & & & & 1 & \\
\hline Leading Aircraftsman & 2 & & & & \\
\hline Leading Signalman & & 1 & & & \\
\hline Lift Attendant & & & & 1 & \\
\hline Lighthouseman & & & 1 & & \\
\hline Marine Officer & & 1 & & 2 & \\
\hline Marine Steward & & 1 & & & \\
\hline Meat Inspector & & & 1 & & \\
\hline Mental Hospital Attendant & 1 & 1 & & 1 & \\
\hline Military Policeman & 1 & & & & 1 \\
\hline Mine Manager & & & 4 & 1 & \\
\hline Ministry of Supply & & & & & 1 \\
\hline Motor Parts Manager & & 1 & & & \\
\hline Overseer & & & 1 & & \\
\hline Parliamentary Official & 1 & & 1 & & \\
\hline Patrolman & & 1 & & & \\
\hline Petty Officer & 1 & 1 & & & \\
\hline Physical Culture Expert & 1 & 2 & & & \\
\hline Physical Instructor & & & & 1 & \\
\hline Police Constable & 8 & 3 & 8 & 5 & \\
\hline Police Officer & & 1 & 1 & 4 & \\
\hline Police Sergeant & & & 1 & & \\
\hline Postal Clerk & 3 & & & 1 & \\
\hline Postmaster & & & 2 & 2 & \\
\hline Post Office Employee & & 1 & 2 & & \\
\hline Providore & & 1 & & & \\
\hline Public Works Officer & & 1 & & 1 & \\
\hline Quarry Manager & & & 1 & & \\
\hline Railway Clerk & 2 & & & & \\
\hline Railway Foreman & & & 1 & & \\
\hline Railway Guard & & & 1 & 3 & \\
\hline Railway Inspector & & & 1 & & \\
\hline
\end{tabular}




\begin{tabular}{|c|c|c|c|c|c|}
\hline Railway Officer & & & 1 & 2 & \\
\hline Railway Station Master & 1 & & & & \\
\hline Ranger & & & & 1 & \\
\hline Reservoir Custodian & & & & 1 & \\
\hline Road Inspector & & & & 1 & \\
\hline Sales Manager & 1 & 1 & & & \\
\hline Sanitary Inspector & & & 1 & 1 & \\
\hline Sawmill Manager & & & 1 & & \\
\hline Shipping Officer & & 1 & & 1 & \\
\hline Shipping Supervisor & & & 1 & & \\
\hline Ship Steward & 5 & & & & \\
\hline Shop Manager & & 1 & & & \\
\hline Skating Rink Assistant & & 1 & & & \\
\hline Station Master & & & 2 & 2 & \\
\hline Store Manager & & 1 & & 1 & \\
\hline Stud Manager & & & & & 1 \\
\hline Superintendent & 2 & & 2 & & \\
\hline Supervisor & & 1 & & 1 & \\
\hline Surveyor of Ships & & 1 & & & \\
\hline Telegraph Overseer & & & 1 & & \\
\hline Telegraphist & 5 & 1 & & 2 & \\
\hline Telephonist & 1 & 1 & & & \\
\hline Traffic Manager & & & 1 & & \\
\hline Tram Guard & 1 & & & & \\
\hline Tramway Inspector & & 1 & & 1 & \\
\hline Tramway Manager & & 1 & & & \\
\hline Warehouse Manager & & & 1 & & \\
\hline Water Inspector & & & 1 & & \\
\hline
\end{tabular}

\section{White-Collars (06)}

\begin{tabular}{|l|l|l|l|l|l|}
\hline Accounts Clerk & 1 & & & & \\
\hline Advertising Agent & & & & & 1 \\
\hline Agent & 2 & 9 & 7 & 2 & 1 \\
\hline Bank Clerk & 3 & 1 & & & \\
\hline Bank Messenger & 2 & & & & \\
\hline Bank Officer & 2 & 1 & 1 & 1 & \\
\hline Billiard Manager & & & & 1 & \\
\hline Billiard Saloon Keeper & & & & 1 & \\
\hline Bondstoreman & & 1 & & & \\
\hline Book Keeper & 1 & & 3 & & \\
\hline Broker & & & 2 & & \\
\hline Buyer & & & 2 & 1 & \\
\hline Canvasser & 2 & 1 & 2 & 2 & \\
\hline Car Salesman & & & 1 & & \\
\hline Chemist's Assistant & 1 & & & & \\
\hline Cinematographer & 1 & & & & \\
\hline Clerk & 85 & 78 & 33 & 48 & 7 \\
\hline
\end{tabular}




\begin{tabular}{|c|c|c|c|c|c|}
\hline Commercial Representative & 1 & & & & \\
\hline Commercial Traveller & 10 & 15 & 19 & 11 & 2 \\
\hline Commission Agent & 3 & 1 & 3 & 5 & \\
\hline Company Representative & & 1 & 1 & & \\
\hline Corporation Employee & & 1 & & 1 & \\
\hline Cycle Agent & 2 & & & & \\
\hline Dealer & & & 1 & 6 & \\
\hline \multicolumn{6}{|l|}{ Dock Company Cashier } \\
\hline Draper's Assistant & 2 & & 1 & & \\
\hline Drapery Salesman & 1 & & & & \\
\hline Estate Agent & 1 & 1 & & & 1 \\
\hline Exhibition Demonstrator & 1 & & & & \\
\hline Expressman & & 1 & 1 & 3 & \\
\hline Film Representative & & 1 & & & \\
\hline Firm's Representative & 1 & & & & \\
\hline General Secretary & & & & 1 & \\
\hline Gold Buyer & & & 1 & & \\
\hline Grocer's Assistant & 5 & & & & 1 \\
\hline Hardware Assistant & & 1 & & & \\
\hline Hardware Salesman & 1 & & & & \\
\hline Headquarters Staff & & & & & 1 \\
\hline Horse Keeper & & & & 1 & \\
\hline Hospital Secretary & & & 1 & & \\
\hline Importer & & & 1 & & \\
\hline Indent Agent & 2 & 3 & 3 & & \\
\hline Indentor & 1 & & 1 & & \\
\hline Insurance Agent & 3 & 5 & 4 & 3 & \\
\hline Insurance Broker & & & 1 & & 1 \\
\hline Insurance Canvasser & & & & & 1 \\
\hline Insurance Clerk & 2 & 3 & & & \\
\hline Land Agent & 3 & 4 & 4 & 1 & \\
\hline Law Clerk & 3 & & & 2 & \\
\hline Letter Carrier & 1 & & & & \\
\hline Life Assurance Agent & & & 1 & & \\
\hline Local Body Employee & 1 & & & & \\
\hline Manufacturer's Agent & & 2 & 1 & & \\
\hline Manufacturer's Representative & 1 & 1 & 1 & 1 & \\
\hline Messenger & & 4 & 2 & 2 & \\
\hline Milking Machine Agent & 1 & & & & \\
\hline Mill Orderman & & & & 1 & \\
\hline Motor Agent & & 1 & & & \\
\hline Motor Car Salesman & 1 & 1 & & 1 & \\
\hline Newsvendor & & 1 & & & \\
\hline Photographic Salesman & 1 & & & & \\
\hline Picture Showman & 1 & & & & \\
\hline Planner & & & & 1 & \\
\hline Postman & 1 & & 3 & 2 & \\
\hline Preserver & & 1 & & & \\
\hline
\end{tabular}




\begin{tabular}{|l|l|l|l|l|l|}
\hline Private Detective & & & & 1 & \\
\hline Private Secretary & & & & 1 & \\
\hline Publisher's Assistant & 1 & 1 & & & 1 \\
\hline Purser & 2 & 1 & & & \\
\hline Rent Collector & 1 & & & & \\
\hline Salesman & 40 & 22 & 3 & 6 & 4 \\
\hline Sales Agent & & 1 & & & \\
\hline Sales Executive & & 1 & & & \\
\hline Secretary & 1 & 2 & 5 & 7 & \\
\hline Shipper's Representative & 1 & & & & \\
\hline Shipping Agent & 1 & 1 & & & \\
\hline Ship's Broker & & & 1 & & \\
\hline Shop Assistant & 4 & 3 & & & 1 \\
\hline Shop Man & & & & 1 & \\
\hline State Agent & 1 & & 1 & & \\
\hline Stationer & 1 & 1 & 1 & & \\
\hline Trade Union Secretary & & & 1 & & \\
\hline Traffic Clerk & & & 1 & & \\
\hline Traveller & 8 & 14 & 7 & 1 & 1 \\
\hline Undertaker & 1 & & 2 & & \\
\hline Union Secretary & & & 1 & & \\
\hline Window Dresser & 1 & & & & \\
\hline
\end{tabular}

\section{$\underline{\text { Skilled (07) }}$}

\begin{tabular}{|l|l|l|l|l|l|}
\hline Aircraftsman & 1 & 4 & & & \\
\hline Airforce Mechanic & 1 & & & & \\
\hline Airman & 2 & 1 & & & \\
\hline Artificial Limb Maker & 1 & & & & \\
\hline Artillery Man & 1 & & & & \\
\hline Asbestos Insulator & 1 & & & & \\
\hline Bacon Curer & & & 1 & & \\
\hline Baker & 12 & 2 & 19 & 14 & 1 \\
\hline Barber & & & & 2 & \\
\hline Basket Maker & 1 & 1 & & 1 & \\
\hline Battery Electrician & & 1 & & & \\
\hline Battery Maker & 1 & & & & \\
\hline Billiard Table Fitter & 1 & 1 & & & \\
\hline Biograph Operator & 1 & 1 & & & \\
\hline Biscuit Maker & & & & 1 & \\
\hline Blacksmith & 11 & 7 & 21 & 19 & 3 \\
\hline Blindmaker & & & 1 & 1 & \\
\hline Blockmaker & & & 1 & & \\
\hline Boiler Maker & 8 & 5 & 6 & 8 & \\
\hline Bookbinder & & 1 & 1 & & \\
\hline Boot Clicker & 1 & 1 & & & \\
\hline Boot Finisher & 1 & 1 & & 1 & \\
\hline Bootmaker & 18 & 10 & 20 & 20 & \\
\hline
\end{tabular}




\begin{tabular}{|c|c|c|c|c|c|}
\hline Boot Repairer & 1 & 1 & & 1 & 1 \\
\hline Boot Worker & & 1 & & 1 & \\
\hline Brass Finisher & & & 2 & & \\
\hline Brewer & 1 & 1 & 1 & 5 & \\
\hline Bricklayer & 2 & 1 & 8 & 3 & 1 \\
\hline Brick Maker & 3 & & 3 & 1 & \\
\hline Brush Maker & 2 & & & 1 & \\
\hline Brush Mason & 1 & & & & \\
\hline Builder & 12 & 14 & 35 & 32 & 2 \\
\hline Butcher & 19 & 7 & 17 & 27 & 3 \\
\hline Butter Maker & & & & 1 & \\
\hline Cabinet Maker & 8 & 6 & 9 & 11 & \\
\hline Carpenter & 58 & 59 & 72 & 57 & 6 \\
\hline Car Adjuster & 1 & 1 & & & \\
\hline Carriage Builder & 1 & & & & \\
\hline Carriage Painter & & & & & 1 \\
\hline Chairmaker & 1 & & & & \\
\hline Cheese Maker & 3 & 1 & & & \\
\hline Chocolate Maker & 1 & & & & \\
\hline Clay Moulder & 1 & & & & \\
\hline Clothier & & 1 & 2 & 1 & \\
\hline Cloth Fuller & & & 1 & & \\
\hline Coach Builder & 3 & 1 & 4 & 2 & \\
\hline Coach Painter & 2 & 2 & 1 & & \\
\hline Coach Trimmer & & & & 1 & \\
\hline Compositor & 5 & 3 & 5 & 4 & \\
\hline Confectioner & 3 & 2 & 3 & 7 & 1 \\
\hline Cooper & 1 & & 2 & 2 & 1 \\
\hline Coppersmith & & & 1 & 1 & \\
\hline Cork Cutter & 1 & & & 1 & \\
\hline Corset Presser & & & & 1 & \\
\hline Cotton Weaver & 1 & & & 1 & \\
\hline Cutter & 7 & 4 & 1 & & \\
\hline Cycle Mechanic & 3 & 2 & 1 & 2 & \\
\hline Cyclist & 1 & & & & \\
\hline Decorator & 3 & 1 & 2 & 2 & \\
\hline Dental Technician & 6 & 3 & & & \\
\hline Drainlayer & & 1 & & 2 & \\
\hline Dyer & 1 & 1 & 3 & 2 & \\
\hline Electrician & 13 & 7 & 2 & 9 & \\
\hline Electrical Worker & 1 & 1 & & & \\
\hline Electric Wireman & & & & 1 & \\
\hline Electroplater & 1 & 1 & & & \\
\hline Electroplater and Stereotyper & & & 1 & & \\
\hline Eletrotyper and Stereotyper & 1 & & & & \\
\hline Enameller & 1 & & & & \\
\hline Engineer & 35 & 39 & 45 & 34 & 1 \\
\hline Engine Driver & 6 & 6 & 10 & 8 & \\
\hline
\end{tabular}




\begin{tabular}{|c|c|c|c|c|c|}
\hline Engine Fitter & & & 1 & 1 & \\
\hline Engraver & 1 & 1 & & & \\
\hline Farrier & 1 & 1 & & 2 & \\
\hline Fellmonger & & 1 & 1 & 2 & \\
\hline Fibrous Plaster Worker & & 1 & & & \\
\hline Fitter & 13 & 9 & 7 & 5 & 1 \\
\hline Flax Miller & & 2 & 1 & & \\
\hline Flourmiller & & 1 & & 2 & \\
\hline Foreman & 2 & 6 & 14 & 10 & 1 \\
\hline Foreman Carpenter & & 1 & & & \\
\hline Foreman Driver & & 1 & & & \\
\hline Foreman Ganger & & 1 & & & \\
\hline Foundryman & 1 & & & & \\
\hline French Polisher & 1 & 2 & 2 & 1 & \\
\hline Furniture Expert & 1 & & & & \\
\hline Furniture Maker & & & 1 & & \\
\hline Gardener & 3 & 2 & 23 & 16 & 1 \\
\hline Gas Engineer & & & 1 & & \\
\hline Gas Fitter & 3 & 2 & 1 & 3 & \\
\hline Gas Meter Maker & 1 & & & & \\
\hline Gas Repair Man & & 1 & & & \\
\hline Gas Service Layer & & & 1 & & \\
\hline Glass Beveller & 2 & 2 & & 1 & \\
\hline Glass Maker & & & & 1 & \\
\hline Glazier & 2 & & & 1 & \\
\hline Golf Professional & 2 & 1 & 1 & & \\
\hline Granite Polisher & 1 & 1 & 1 & & \\
\hline Hairdresser & 18 & 12 & 10 & 7 & \\
\hline Horse Trainer & & 1 & 4 & 8 & 1 \\
\hline Instrument Maker & & & 1 & 1 & \\
\hline Iron Dresser & & & & 1 & \\
\hline Iron Moulder & 1 & & 1 & 4 & \\
\hline Iron Turner & 1 & & & & \\
\hline Jeweller & 5 & 9 & 3 & 8 & \\
\hline Jockey & 3 & 1 & 1 & & \\
\hline Joiner & 5 & 5 & 1 & 2 & 1 \\
\hline Lapidist & & 1 & & & \\
\hline Line Erector & 3 & 1 & & & \\
\hline Linesman & 9 & 6 & 4 & 2 & 1 \\
\hline Linotyper & 1 & 2 & & & \\
\hline Maltster & & & & 1 & 1 \\
\hline Mariner & 7 & 4 & 13 & 11 & \\
\hline Marine Radio Operator & 1 & 1 & & & \\
\hline Mechanic & 27 & 32 & 2 & 5 & 1 \\
\hline Mechanician & 2 & & & 1 & \\
\hline Mercantile Marine Mate & 1 & & & & \\
\hline Merchant Navy & 1 & 1 & & & \\
\hline Merchant Seaman & 1 & 1 & & 1 & \\
\hline
\end{tabular}




\begin{tabular}{|c|c|c|c|c|c|}
\hline Merchant Tailor & & & 1 & & \\
\hline Metal Polisher & & 1 & & & \\
\hline Miller & 1 & & 2 & 3 & \\
\hline Mill Furnisher & & 1 & & & \\
\hline Millwright & & & 1 & 3 & \\
\hline Miner & 14 & 6 & 18 & 39 & 1 \\
\hline Modeller & & 1 & & & \\
\hline Monumental Mason & & & 1 & & \\
\hline Motor Assembler & 1 & 3 & & & \\
\hline Motor Engineer & 3 & 3 & & & \\
\hline Motorman & 5 & 4 & 1 & & 1 \\
\hline Moulder & 1 & 1 & 4 & & \\
\hline Naval Seaman & 1 & & & & \\
\hline Nurseryman & 1 & 1 & 2 & 2 & \\
\hline Orchardist & 3 & 2 & 3 & & \\
\hline Organ Builder & & & 1 & & \\
\hline Painter & 27 & 25 & 21 & 21 & 1 \\
\hline Panel Beater & 3 & 1 & & & \\
\hline Paper Hanger & & & & 1 & \\
\hline Pastry Cook & 6 & 2 & 2 & & \\
\hline Piano Tuner & & 1 & & 1 & \\
\hline Pickler & & & 1 & & \\
\hline Picture Framer & & & & 1 & \\
\hline Pipe Maker & 1 & & & & \\
\hline Plan Printer & & & & 1 & \\
\hline Plasterer & 4 & 7 & 4 & 5 & 1 \\
\hline Plumber & 22 & 16 & 16 & 12 & 2 \\
\hline Polisher & & & & 1 & \\
\hline Potter & & & 3 & & \\
\hline Presser & 4 & 5 & & & 1 \\
\hline Printer & 8 & 8 & 11 & 8 & \\
\hline Prospector & & & & 1 & \\
\hline Radiator Repairer & 1 & & & & \\
\hline Radio Engineer & 1 & 1 & & 1 & \\
\hline Radio Mechanic & 1 & 1 & & & \\
\hline Radio Technician & & 1 & & & \\
\hline Rigger & 1 & 1 & & 1 & \\
\hline Saddler & 6 & 2 & 1 & 4 & \\
\hline Sail Maker & & 2 & 1 & & \\
\hline Sailor & 1 & & 3 & 4 & \\
\hline Saw Doctor & & & 1 & & \\
\hline Sawmiller & 1 & & 10 & 6 & \\
\hline Scaffolder & 1 & 1 & & & \\
\hline Seagrass Worker & 1 & 1 & & & \\
\hline Seaman & 37 & 31 & 13 & 8 & 10 \\
\hline Ship Builder & & & & 1 & \\
\hline Shipwright & 3 & & 5 & 2 & \\
\hline Shirt Maker & & & 1 & & \\
\hline
\end{tabular}




\begin{tabular}{|c|c|c|c|c|c|}
\hline Shoemaker & 1 & & 1 & 1 & \\
\hline Shop Decorator & & & 1 & & \\
\hline Signalman & 1 & & 1 & & \\
\hline Signwriter & & 1 & 1 & 2 & \\
\hline Silk Weaver & & & 1 & & \\
\hline Silversmith & & & 1 & 1 & \\
\hline Sizemaker & & & 1 & & \\
\hline Skiff Repairer & & 1 & & & \\
\hline Slaughterman & 6 & 3 & 1 & 3 & \\
\hline Slipper Maker & 1 & 1 & & & \\
\hline Soap Maker & 1 & & 2 & & \\
\hline Spray Painter & & 2 & & & \\
\hline Stable Keeper & & & 1 & & \\
\hline Steel Erector & & & & 1 & \\
\hline Stereotyper & 1 & 1 & & & \\
\hline Stone Cutter & 1 & 1 & & & \\
\hline Stone Mason & 1 & & 2 & 5 & \\
\hline Stone Polisher & & & 1 & & \\
\hline Swimming Instructor & & 1 & & & \\
\hline Tailor & 10 & 6 & 14 & 14 & 2 \\
\hline Tailor's Cutter & 2 & 2 & 1 & & \\
\hline Tailor's Presser & & & 1 & & 1 \\
\hline Tanner & & & 1 & & \\
\hline Tannery Employee & & & 1 & & \\
\hline Tiller & 1 & 2 & & & \\
\hline Timber Miller & 1 & & & & \\
\hline Tinsmith & 3 & 1 & 2 & 1 & \\
\hline Tool Setter & & & & 1 & \\
\hline Trainer & & & 2 & & \\
\hline Tram Driver & 1 & & & & \\
\hline Tramway Motorman & 1 & 4 & 2 & 4 & \\
\hline Turner & 1 & & 1 & & \\
\hline Upholsterer & 1 & 2 & 3 & 2 & \\
\hline Vulcaniser & & 1 & & & \\
\hline Watchmaker & 1 & 1 & 2 & 3 & \\
\hline Weaver & & 1 & & 1 & \\
\hline Welder & 5 & 4 & 1 & & 3 \\
\hline Wheelwright & 1 & & 3 & 3 & \\
\hline Wicker Worker & 2 & & 1 & & \\
\hline Wine Brewer & 1 & & 1 & & \\
\hline Wireless Operator & & 1 & & & \\
\hline Wood Carver & & & & 1 & \\
\hline Wood Turner & 1 & & 1 & & \\
\hline Wool Presser & & & 1 & & \\
\hline Wrestler & 1 & & & & \\
\hline
\end{tabular}


$\underline{\text { Semi-Skilled (08) }}$

\begin{tabular}{|c|c|c|c|c|c|}
\hline Accommodation Housekeeper & & 1 & & & \\
\hline Ambulance Driver & 1 & 1 & & & \\
\hline \multicolumn{6}{|l|}{ Assistant } \\
\hline Battery Company Employee & & & & 1 & \\
\hline Battery Hand & & & & 1 & \\
\hline Benchman & 1 & 1 & & & 1 \\
\hline Blacksmith's Striker & 1 & & & & \\
\hline Brewer's Assistant & 1 & & 1 & 1 & \\
\hline Bulldozer Driver & & & & & 1 \\
\hline Bus Driver & & 3 & & & 1 \\
\hline Cab Driver & 2 & & & & 1 \\
\hline Cabman & 1 & & & & \\
\hline Caretaker & & 4 & 4 & 7 & \\
\hline Caterer & 2 & 1 & 2 & & \\
\hline Chauffeur & 4 & 1 & & & \\
\hline Cheese Factory Assistant & 1 & & & & \\
\hline Chef & 3 & 3 & 1 & 2 & 1 \\
\hline Clicker & & 1 & & & \\
\hline Club Steward & 4 & 2 & & & \\
\hline Coach Driver & & & 1 & & \\
\hline Coachman & & & 1 & 2 & \\
\hline Coal Miner & & & 6 & 3 & \\
\hline Cook & 11 & 9 & 5 & 2 & 4 \\
\hline Crane Driver & 1 & 3 & & 2 & \\
\hline Dairy Factory Assistant & 1 & & & & \\
\hline Driver & 23 & 30 & 10 & 8 & 10 \\
\hline Dry Cleaner & 1 & 1 & & & \\
\hline Engineer's Assistant & 1 & & & 1 & \\
\hline Fireman & 12 & 6 & 2 & 4 & 2 \\
\hline Fisherman & 2 & 3 & 4 & 5 & 1 \\
\hline Flock Machinist & 1 & & & & \\
\hline Furniture Assistant & & & 1 & & \\
\hline Fuser & & 1 & & & \\
\hline Garage Assistant & 1 & 1 & & & \\
\hline Garage Attendant & 4 & 1 & & & 1 \\
\hline Gas Stoker & & & & 4 & \\
\hline Gas Works Employee & & 2 & 1 & & \\
\hline Gripman & & & 1 & & \\
\hline Groom & 3 & 1 & & & \\
\hline Harness Plater & & & 1 & & \\
\hline Iron Machinist & & & & 1 & \\
\hline Jeweller's Assistant & 1 & & & & \\
\hline Letterpress Machinist & 2 & & & & \\
\hline Lorry Driver & 2 & 3 & 1 & 4 & 1 \\
\hline Machine Attendant & & & 1 & & \\
\hline Machinist & 5 & 7 & 3 & 2 & 1 \\
\hline
\end{tabular}




\begin{tabular}{|c|c|c|c|c|c|}
\hline Marine Fireman & 1 & & 1 & & \\
\hline Mariner Stoker & & & 1 & & \\
\hline Mattress Maker & 2 & 1 & & & \\
\hline Metal Worker & 1 & & & & \\
\hline Metal Driver & 1 & & & & \\
\hline Millhand & 2 & 1 & 1 & & 1 \\
\hline Motor Driver & 23 & 14 & 4 & 4 & 2 \\
\hline Nightwatchman & 1 & 3 & 5 & 4 & \\
\hline Orchard Assistant & 1 & & & & \\
\hline Paper Ruler & 1 & & & & \\
\hline Photographer's Assistant & 1 & & & & \\
\hline Pipe Machinist & & 1 & & & \\
\hline Railway Employee & 6 & 19 & 10 & 18 & 2 \\
\hline Railway Ganger & & & 2 & 2 & \\
\hline Range Fitter & & 1 & 1 & & \\
\hline Rope Maker & 1 & 1 & 2 & & \\
\hline Sawyer & 1 & & 1 & 4 & \\
\hline Sewerage Stormer & & & & 1 & \\
\hline Sheet Metal Worker & & & 1 & & \\
\hline Shoe Hand & & & & 1 & \\
\hline Spinner & & & & 1 & \\
\hline Stationary Engine Driver & 1 & 1 & 1 & & \\
\hline Steward & 6 & 6 & 1 & & 6 \\
\hline Stoker & 2 & & 2 & 1 & \\
\hline Taxi Driver & 8 & 17 & 3 & 5 & 4 \\
\hline Teamster & 1 & & & 1 & \\
\hline Telephone-line Worker & 1 & 2 & & & \\
\hline Tractor Driver & & 1 & & & \\
\hline Tramway Conductor & 7 & 8 & & 1 & 1 \\
\hline Tramway Employee & 2 & 9 & & 3 & 1 \\
\hline Transport Company Employee & & & & & 1 \\
\hline Truck Driver & 2 & 1 & 1 & & 1 \\
\hline Tyre Retreader & & 2 & & & \\
\hline Van Driver & 1 & & & & \\
\hline Vanman & & & & 1 & \\
\hline Wagon Backer & & & & 1 & \\
\hline Waterworks Employee & & 1 & & & \\
\hline Winchman & & & & & 1 \\
\hline Wire Mattress Maker & & 1 & & & \\
\hline Wood Machinist & 1 & 2 & 1 & 1 & \\
\hline
\end{tabular}

$\underline{\text { Unskilled (09) }}$

\begin{tabular}{|l|l|l|l|l|l|}
\hline Asphalter & & 1 & 1 & 2 & \\
\hline Barman & 2 & 13 & & 7 & 6 \\
\hline Billiard Room Attendant & & 1 & & & \\
\hline Bottler & 1 & & & & \\
\hline
\end{tabular}




\begin{tabular}{|c|c|c|c|c|c|}
\hline Box Maker & 1 & & & & \\
\hline Bus Cleaner & & 1 & & & \\
\hline Butler & & & 2 & & \\
\hline Canteen Worker & & 1 & & & \\
\hline Car Cleaner & 1 & 1 & & & \\
\hline Carrier & 7 & 14 & 15 & 19 & 1 \\
\hline Carter & 10 & 2 & 5 & 6 & 1 \\
\hline Casing Worker & 1 & & & & \\
\hline Cement Worker & & 1 & & & \\
\hline Chainman & & & & 1 & \\
\hline Cleaner & 1 & & 1 & & 1 \\
\hline Cloth Packer & & & 1 & 1 & \\
\hline Cotton Spinner & & & 2 & & \\
\hline Dock Worker & & & 1 & & \\
\hline Factory Employee & 1 & 1 & & & \\
\hline Factory Hand & 2 & 2 & & & 2 \\
\hline Factory Worker & 1 & 2 & & & 1 \\
\hline Freezer & & 1 & & & \\
\hline Freezing Works Employee & 2 & 1 & 1 & 2 & 1 \\
\hline Furnaceman & & 1 & 1 & & \\
\hline Furniture Packer & & 1 & & & \\
\hline General Worker & 1 & & & & \\
\hline Greaser & 1 & & & & \\
\hline Hospital Orderly & 1 & & & 1 & \\
\hline Hotel Employee & & 3 & & & \\
\hline Hotel Porter & 1 & 1 & & & \\
\hline Hotel Worker & 2 & 3 & & & 1 \\
\hline Iron Foundry Employee & & 1 & & & \\
\hline Iron Worker & 1 & & 2 & & \\
\hline Labourer & 173 & 162 & 151 & 206 & 51 \\
\hline Laundry Man & 1 & 2 & & & \\
\hline Liftman & & & & 1 & \\
\hline Lounge Steward & 1 & 1 & & & \\
\hline Motor Car Trimmer & 1 & & & & \\
\hline Motor Trimmer & 2 & 1 & & & \\
\hline Motor Works Employee & & 1 & & & \\
\hline Munitions Worker & & & & 1 & \\
\hline Packer & 2 & 2 & 1 & 1 & \\
\hline Platelayer & 1 & 2 & 2 & 5 & \\
\hline Porter & 1 & 2 & & & \\
\hline Public Works Employee & & 7 & & & \\
\hline Railway Cleaner & 1 & & & & \\
\hline Railway Hand & & 1 & & & \\
\hline Railway Porter & 6 & 3 & & & 1 \\
\hline Relief Worker & & 3 & & & 1 \\
\hline Roadman & & & & 1 & \\
\hline Road Board Employee & & & & 1 & \\
\hline Sawmill Hand & 1 & & & & \\
\hline
\end{tabular}




\begin{tabular}{|l|l|l|l|l|l|}
\hline Stevedore & 1 & 1 & 5 & 3 & \\
\hline Storeman & 23 & 17 & 14 & 12 & 2 \\
\hline Surfaceman & 3 & & & 1 & \\
\hline Telegraph Cadet & 1 & & & & \\
\hline Timber Worker & 2 & 1 & & 1 & \\
\hline Tramway Shedhand & & & & 1 & \\
\hline Transport Worker & & & & 1 & \\
\hline Trimmer & 1 & 1 & & & \\
\hline Turncock & & & 1 & & \\
\hline Waiter & 7 & 3 & 1 & 1 & \\
\hline Warehouseman & 17 & 8 & 5 & 3 & 1 \\
\hline Waterside Worker & 6 & 16 & 14 & 11 & 4 \\
\hline Wharf Employee & & 2 & 1 & & 3 \\
\hline Wharf Labourer & 1 & 5 & 2 & 1 & 3 \\
\hline Window Cleaner & & 3 & & & \\
\hline Wool Sorter & 1 & & 1 & & \\
\hline Wool Store Employee & & & & & 1 \\
\hline Wool Worker & 2 & 1 & & & \\
\hline Workman & 1 & & & & \\
\hline
\end{tabular}

\section{$\underline{\text { Rural Proprietors (15) }}$}

\begin{tabular}{|l|l|l|l|l|l|}
\hline Farmer & 88 & 61 & 214 & 206 & 11 \\
\hline Runholder & & & & 1 & \\
\hline Station Owner & & & 2 & 1 & \\
\hline
\end{tabular}

\section{$\underline{\text { Rural Occupations (16) }}$}

\begin{tabular}{|l|l|l|l|l|l|}
\hline Boundary Rider & 1 & & & & \\
\hline Bushman & 6 & & 2 & 4 & 1 \\
\hline Drover & & & 1 & 5 & \\
\hline Farm Cadet & 1 & & & & \\
\hline Farm Hand & 6 & 5 & & 1 & 1 \\
\hline Farm Labourer & 2 & & & 1 & 1 \\
\hline Farm Manager & & 1 & & 1 & \\
\hline Farm Steward & & & & 1 & \\
\hline Grazier & & & 2 & 1 & \\
\hline Herd Tester & 1 & & & & \\
\hline Horticulturalist & & & 2 & & \\
\hline Ploughman & 2 & & 1 & 2 & \\
\hline Rabbiter & & & 1 & & \\
\hline Share Milker & & 2 & & & \\
\hline Shearer & 2 & & 1 & 2 & \\
\hline Sheep Station Manager & & & & 1 & \\
\hline Shepherd & 7 & 3 & 2 & 2 & 2 \\
\hline Station Hand & 3 & & & & \\
\hline Station Manager & & & 2 & & \\
\hline
\end{tabular}




\begin{tabular}{|l|l|l|l|l|l|}
\hline Station Superintendent & & & 1 & & \\
\hline Stock Buyer & & & 1 & & \\
\hline Stock Dealer & & & 1 & 1 & \\
\hline Stock Inspector & & & 1 & 1 & \\
\hline Stockman & & & & 1 & \\
\hline Tea Planter & & & 1 & & \\
\hline Trapper & & & & & \\
\hline Vine Grower & & & & \\
\hline
\end{tabular}

$\underline{\text { Students (17) }}$

Rehabilitation Trainee

Student

\begin{tabular}{|l|l|l|l|}
\hline 1 & & & \\
\hline 1 & & & \\
\hline
\end{tabular}

Military (officers) (18)

\begin{tabular}{|l|l|l|l|l|l|}
\hline Army Officer & 2 & & 4 & 1 & \\
\hline Captain in Medical Corps & & 1 & & & \\
\hline Captain - New Zealand Army & 1 & 2 & & & \\
\hline Flight Lieutenant - RNZAF & & 1 & & & \\
\hline Flying Officer & & 1 & & & \\
\hline Imperial Army Officer & & & 1 & 1 & \\
\hline Lieutenant & 2 & & & & \\
\hline Lieutenant in NZEF & 2 & & & & 1 \\
\hline Lieutenant in Navy & & 1 & & & \\
\hline Naval Officer & & & 2 & 3 & \\
\hline Officer - New Zealand Artillery & & 1 & & & \\
\hline Sea Captain & & & 1 & 1 & \\
\hline Second Lieutenant, RAF & 1 & & & & \\
\hline Second Lieutenant, Welsh Regiment & 1 & & & & \\
\hline Sub-Lieutenant - Royal Navy Division & 1 & & & & \\
\hline
\end{tabular}

Military (enlisted and rank undefined) (19)

\begin{tabular}{|l|l|l|l|l|l|}
\hline Airforce & 2 & 2 & & 1 & \\
\hline Armed Forces & 3 & 41 & & & 1 \\
\hline Armourer - Corporal & & 1 & & & \\
\hline Army & & 1 & 1 & & 1 \\
\hline Corporal - Air Force & & 1 & & & \\
\hline Corporal - No. 2 Training Battalion & & 1 & & & \\
\hline Driver - NZ Field Artillery & 1 & & & & \\
\hline Gunner, NZEF & & 1 & & & \\
\hline Gunner, RNZA & 1 & & & & \\
\hline Lance Corporal & & 1 & & & \\
\hline Lance Sergeant & & 1 & & & \\
\hline Navy & 3 & 3 & & & \\
\hline NZEF & 1 & 11 & & & \\
\hline NZEF - New Zealand Engineers & 1 & & & & \\
\hline
\end{tabular}




\begin{tabular}{|l|l|l|l|l|l|}
\hline Petty Officer- Royal Navy & 2 & & 1 & & 1 \\
\hline Private & 2 & & 1 & & \\
\hline Private - New Zealand Forces & 1 & 1 & & & 1 \\
\hline RAF & 2 & & & & \\
\hline Returned Soldier & & 3 & & & 1 \\
\hline Rifleman & 1 & & & & \\
\hline Rifleman, NZRB & 2 & & & & \\
\hline RNAS & 1 & & & & \\
\hline RNZAF & 3 & 10 & & & 3 \\
\hline Seaman, Royal Navy & 1 & & & & \\
\hline Sergeant & 4 & 5 & & & \\
\hline Sergeant Major & 1 & & & & \\
\hline Sergeant Observer & 1 & 1 & & & \\
\hline Soldier & 49 & 28 & 4 & 8 & 5 \\
\hline Staff Sergeant & & 5 & & & \\
\hline US Marine & 7 & 10 & & & 8 \\
\hline
\end{tabular}

Undefined (20)

\begin{tabular}{|l|l|l|l|l|l|}
\hline Aboriginal Native & & 1 & 1 & & 2 \\
\hline Army Pensioner & & & & 1 & \\
\hline Deceased & & & 6 & 3 & \\
\hline Freeholder & & & 1 & & \\
\hline Gentleman & 3 & & 18 & 22 & 1 \\
\hline Independent Means & 1 & 1 & 1 & 3 & \\
\hline Investor & & & & 1 & \\
\hline Landowner & & & 2 & 2 & \\
\hline Maori Chief & 1 & & & & \\
\hline Mill Investor & & & 1 & & \\
\hline No Occupation & & & & 1 & \\
\hline Opposition Organiser & & & & 1 & \\
\hline Pensioner & & 3 & & & \\
\hline Retired & & 1 & 4 & 7 & \\
\hline Settler & 5 & 5 & 11 & 14 & 1 \\
\hline Settler - Pakeha Maori & & & & 1 & \\
\hline Unknown & & & 2 & 3 & \\
\hline War Pensioner & & 2 & & & \\
\hline
\end{tabular}




\section{Summary of Female Occupations}

\begin{tabular}{|l|c|c|}
\hline & A & B \\
\hline Semi-Professionals (03) & 37 & 5 \\
\hline Petty Proprietors (04) & 1 & 2 \\
\hline Petty Officials (05) & 1 & 0 \\
\hline White-Collars (06) & 49 & 3 \\
\hline Skilled (07) & 46 & 5 \\
\hline Semi-Skilled (08) & 18 & 1 \\
\hline Unskilled (09) & 159 & 5 \\
\hline Military (enlisted and rank undefined) (19) & 3 & 0 \\
\hline Undefined (20) & 136 & 2056 \\
\hline TOTAL & $\mathbf{4 5 0}$ & $\mathbf{2 0 7 7}$ \\
\hline
\end{tabular}

Column A - Wife's Occupation at Marriage

Column B - Wife's Occupation at Divorce

\section{$\underline{\text { Semi-Professionals }(03)}$}

\begin{tabular}{|l|l|l|}
\hline Actress & 4 & 1 \\
\hline Dancing Teacher & 2 & \\
\hline Dental Nurse & 1 & \\
\hline Governess & 1 & \\
\hline Kindergarten School Teacher & 1 & \\
\hline Masseuse & 1 & \\
\hline Musician & 1 & \\
\hline Music Teacher & 2 & \\
\hline Nurse & 11 & 2 \\
\hline Optician's Assistant & 1 & \\
\hline Photograph Artiste & 1 & \\
\hline Photographer & 1 & \\
\hline Salvation Army Officer & 1 & \\
\hline Schoolmistress & & 1 \\
\hline School Teacher & 4 & 1 \\
\hline Singer & 1 & \\
\hline Teacher & 4 & \\
\hline
\end{tabular}

Petty Proprietors (04)

\begin{tabular}{|l|l|l|}
\hline Boardinghouse Keeper & 1 & 2 \\
\hline
\end{tabular}

\section{$\underline{\text { Petty Officials (05) }}$}


White-Collars (06)

\begin{tabular}{|l|l|l|}
\hline Artist's Model & 1 & \\
\hline Bank Clerk & 1 & \\
\hline Book Keeper & 1 & \\
\hline Cashier & 2 & \\
\hline Clerk & 10 & \\
\hline Clerk's Assistant & 1 & \\
\hline Dock Company Cashier & 1 & \\
\hline Grocer's Assistant & 1 & \\
\hline Lady Help & 2 & \\
\hline Lady's Companion & 1 & \\
\hline Ledger Clerk & 1 & \\
\hline Manageress & 1 & 1 \\
\hline Model & 1 & \\
\hline Music Warehouse & 1 & \\
\hline Saleswoman & 4 & 1 \\
\hline Shop Assistant & 14 & 1 \\
\hline Shorthand Typist & 2 & \\
\hline Stenographer & 2 & \\
\hline Typist & 2 & \\
\hline
\end{tabular}

Skilled (07)

\begin{tabular}{|l|l|l|}
\hline Bookbinder & 1 & \\
\hline Bootmaker & 1 & \\
\hline Confectioner & 1 & \\
\hline Cork Cutter & 1 & \\
\hline Cotton Weaver & 2 & \\
\hline Dental Technician & 1 & \\
\hline Dressmaker & 15 & 3 \\
\hline Hairdresser & 1 & 1 \\
\hline Land Girl & 1 & \\
\hline Meter Maker & 1 & \\
\hline Milliner & 2 & \\
\hline Rope Maker & 1 & \\
\hline Seamstress & 1 & \\
\hline Tailoress & 12 & 1 \\
\hline Telephonist & 1 & \\
\hline Weaver & 4 & \\
\hline
\end{tabular}

$\underline{\text { Semi-Skilled (08) }}$

\begin{tabular}{|l|l|l|}
\hline Assistant & 1 & 1 \\
\hline Boot Machinist & 1 & \\
\hline Cook & 5 & \\
\hline Draper's Assistant & 1 & \\
\hline Forewoman & 1 & \\
\hline
\end{tabular}




\begin{tabular}{|l|l|l|}
\hline Machinist & 6 & \\
\hline Shoe Hand & 1 & \\
\hline Upholsterer's Assistant & 1 & \\
\hline Winder & 1 & \\
\hline
\end{tabular}

\section{$\underline{\text { Unskilled (09) }}$}

\begin{tabular}{|l|l|l|}
\hline Barmaid & 3 & \\
\hline Cotton Reeler & 2 & \\
\hline Domestic & 115 & \\
\hline Factory Employee & 1 & \\
\hline Factory Hand & 1 & \\
\hline Factory Worker & 1 & \\
\hline Housekeeper & 3 & 2 \\
\hline Housemaid & 5 & 1 \\
\hline Laundress & 1 & 1 \\
\hline Munitions Worker & 1 & \\
\hline Servant & 3 & \\
\hline Stewardess & & 1 \\
\hline Waitress & 22 & \\
\hline War Worker & 1 & \\
\hline
\end{tabular}

Military (enlisted and rank undefined) (19)

\begin{tabular}{|l|l|l|}
\hline RNZAF & 1 & \\
\hline WAAF & 1 & \\
\hline WRNS & 1 & \\
\hline
\end{tabular}

Undefined (20)

\begin{tabular}{|l|l|l|}
\hline At Home & 3 & \\
\hline Domestic Duties & 91 & 1 \\
\hline Half-Caste & 1 & \\
\hline Home Duties & 32 & \\
\hline Household Duties & 4 & \\
\hline Housewife & 2 & \\
\hline Independent Means & 1 & \\
\hline Lady & 1 & \\
\hline Married Woman & & 2055 \\
\hline Single Young Person & 1 & \\
\hline
\end{tabular}




\section{Bibliography}

\section{A. Primary Sources}

I. Unpublished Papers and Manuscripts

1. Alexander Turnbull Library, Wellington

MS-Group-0180 New Zealand Society for the Protection of Home and Family

Annual Reports 1897-1919, MSX-3292

Annual Reports 1932-1966, MSX-3294

Minute Book 13 Aug 1901 - 23 Sept 1904, qMS-1561

MS-Group-0225 National Council of Women of New Zealand

Constitution and Conference Minutes 1896, MS-Papers-1371-106

2. Archives New Zealand, Wellington

AAOM $6042 \quad$ Divorce Registers, Wellington Supreme Court, 1868 - 1947

AAOM W3265 Divorce Files, Wellington Supreme Court, 1898 - 1947

AAYS 8638 AD1 Divorce Proceedings Affecting Members of $2^{\text {nd }}$ NZEF, 1346/320/4/6

AAYT 8490 N1 Regulations, Publications - Acts - Divorce and Matrimonial Causes Act, 525/18/1/18

ACGS $16211 \mathrm{~J} 1 \quad$ As to service of divorce papers on members of United States Forces in New Zealand who are cited as parties to proceedings in the Supreme Court, 1104/1942/35/66

Matrimonial Causes (Dominion Troops) Act (Imp) - Re provision for dealing with divorce and matrimonial cases of servicemen married overseas, 1117/1944/42/9

3. National Archives United Kingdom, Kew Gardens

DO35/132/12 Nationality of Women following Divorce, Dominion Office Records, 1930-1936

4. Women's Library, London Metropolitan University

5MWA $\quad$ Married Women's Association Records, 1943-1988

II. Published Official Papers

Gazette Law Reports (New Zealand), 1921

Journals of the House of Representatives, 1907 - 1935

New Zealand Census, 1896 - 1956

New Zealand Law Reports, 1899 - 1951 
New Zealand Official Year Book, 1898 - 1959

New Zealand Parliamentary Debates, 1920 - 1958

Report of the Royal Commission on Divorce and Matrimonial Causes, 1909 - 1912. London: His Majesty's Stationery Office, 1913.

Report of the Royal Commission on Marriage and Divorce Report 1951 - 1955. London: Her Majesty's Stationery Office, 1956.

Report of the Special Committee on Moral Delinquency in Children and Adolescents. Wellington: Government Printer, 1954.

Report on Justice Statistics (New Zealand), 1921 - 1959

Statistics of New Zealand, 1898 - 1920

III. Contemporary Newspapers and Periodicals

Auckland Star, 1953

Colonist, 1899

Church Gazette, 1894 - 1896

Evening Post, 1897 - 1960

Nelson Evening Mail, 1895

New Zealand Herald, 1953

New Zealand Law Journal, 1928 - 1955

New Zealand Tablet, 1903 - 1906

New Zealand Truth, 1910 - 1945

Observer, 1901 - 1903

Otago Daily Times, 1895 - 1897

Star, 1898

The Times (London), 1921 - 1953

Wanganui Herald, 1906

White Ribbon, 1896 - 1898

IV. Contemporary Books and Articles

Hanlon, A.C. Random Recollections. Notes on a Lifetime at the Bar. Dunedin: Otago Daily Times and Witness Newspapers, 1939.

Mace, David R. Marriage Crisis. London: Delisle, 1948.

- Marriage. The Art of Lasting Happiness. London: Hodder and Stoughton, 1952.

—. Success in Marriage. London: Hulton Press, 1958.

1953.

Whom God Hath Joined. A Book of Christian Marriage. London: Epworth Press, 
Youth Looks Towards Marriage. London: Darwen Finlayson, 1958.

Nixon, A.J. Divorce in New Zealand: A Preliminary Survey. Auckland: Auckland University College, 1954.

Stopes, Marie. Married Love, 1918. Edited with an introduction and notes by Ross McKibbin. Oxford: Oxford University Press, 2004.

\section{B. Secondary Sources}

VI. Books

Allen, Judith. Sex and Secrets. Crimes Involving Australian Women Since 1880. Melbourne: Oxford University Press, 1990.

Backhouse, Constance. Petticoats \& Prejudice. Women and Law in Nineteenth-Century Canada. Toronto: Women's Press, 1991.

Bailey, Beth L. From Front Porch to Back Seat: Courtship in Twentieth-Century America. Baltimore: John Hopkins University Press, 1988.

Baker, J.H. An Introduction to English Legal History. 4th ed. London: Butterworths, 2002.

Basch, Norma. Framing American Divorce: From the Revolutionary Generation to the Victorians. Berkeley: University of California Press, 1999.

Bassett, Michael. Sir Joseph Ward. A Political Biography. Auckland: Auckland University Press, 1993.

Bassett, Michael with Michael King. Tomorrow Comes the Song. A Life of Peter Fraser. Auckland: Penguin, 2000.

Belich, James. Making Peoples. A History of the New Zealanders from Polynesian Settlement to the end of the Nineteenth Century. Auckland: Allen Lane, 1996.

-Paradise Reforged. A History of the New Zealanders from the 1880s to the Year 2000. Auckland: Allen Lane, 2001.

Berube, Allan. Coming Out Under Fire: The History of Gay Men and Women in World War Two. New York: Free Press, 1988.

Braybon, Gail and Penny Summerfield. Out of the Cage: Women's Experiences in Two World Wars. London: Pandora, 1987.

Brickell, Chris. Mates \& Lovers. A History of Gay New Zealand. Auckland: Godwit, 2008.

Brook, Heather. Conjugal Rites: Marriage and Marriage-like Relationships before the Law. New York: Palgrave Macmillan, 2007. 
Brookes, Barbara, ed. At Home in New Zealand: History, Houses, People. Wellington: Bridget Williams Books, 2000.

Brookes, Barbara, Annabel Cooper and Robin Law, eds. Sites of Gender. Women, Men and Modernity in Southern Dunedin, 1890-1939. Auckland: Auckland University Press, 2003.

Brookes, Barbara, Charlotte Macdonald and Margaret Tennant, eds. Women in History: Essays on European Women in New Zealand. Wellington: Allen \& Unwin/Port Nicholson Press, 1986.

Bridget Williams Books, 1992.

Brown, Callum G. The Death of Christian Britain: Understanding Secularisation, 18002000. London: Routledge, 2000.

- Religion and Society in Twentieth-Century Britain. Harlow, UK: Pearson, 2006.

Byrnes, Giselle, ed. The New Oxford History of New Zealand. Melbourne: Oxford University Press, 2009.

Carter, Sarah. The Importance of Being Monogamous. Marriage and Nation Building in Western Canada to 1915. Edmonton: University of Alberta Press, 2008.

Celello, Kristin. Making Marriage Work. A History of Marriage and Divorce in the Twentieth-Century United States. Chapel Hill: University of North Carolina Press, 2009.

Clark, Anna. Desire. A History of European Sexuality. New York and London: Routledge, 2008.

Cocks, H.G. and Matt Houlbrook, eds. The Modern History of Sexuality. Houndmills: Palgrave Macmillan, 2006.

Coleborne, Catharine. Madness in the Family. Insanity and Institutions in the Australasian Colonial World, 1860-1914. Houndmills: Palgrave Macmillan, 2010.

Coney, Sandra, ed. Standing in the Sunshine: A History of New Zealand Women Since They Won the Vote. Auckland: Penguin, 1993.

Cook, Hera. The Long Sexual Revolution. English Women, Sex and Contraception, 18001975. Oxford: Oxford University Press, 2004.

Cooke, Robin, ed. Portrait of a Profession. The Centennial Book of the New Zealand Law Society. Wellington: A.H. \& A.W. Reed, 1969.

Coontz, Stephanie. Marriage: A History from Obedience to Intimacy or How Love Conquered Marriage. New York: Viking, 2005. 
The Social Origins of Private Life. A History of American Families 1600-1900. London and New York: Verso, 1988.

. The Way We Never Were. American Families and the Nostalgia Trap. New York: Basic Books, 2000 ed.

Costello, John. Love, Sex and War. Changing Values, 1939-45. London: Collins, 1985.

Cott, Nancy F. Public Vows. A History of Marriage and the Nation. Cambridge, Mass.: Harvard University Press, 2000.

Crawford, John and Ian McGibbon, eds. New Zealand's Great War. New Zealand, the Allies \& the First World War. Auckland: Exisle, 2007.

Cullen, M.J. Lawfully Occupied. Otago District Law Society. Dunedin: Otago District Law Society, 1979.

Daley, Caroline. Girls and Women, Men and Boys: Gender in Taradale, 1886-1930. Auckland: Auckland University Press, 1999.

Daley, Caroline and Deborah Montgomerie, eds. The Gendered Kiwi. Auckland: Auckland University Press, 1999.

Dalley, Bronwyn. Family Matters. Child Welfare in Twentieth-Century New Zealand. Auckland: Auckland University Press, 1998.

Daly, Jennifer M. MG Reflecting. A Portrait of Marriage Guidance New Zealand 1949 to 1989. Wellington: National Marriage Guidance Council, 1989.

Dalziel, Raewyn. Focus on the Family: The Auckland Home and Family Society 1893 1993. Auckland: David Ling, 1993.

Damousi, Joy and Marilyn Lake, eds. Gender and War: Australians at War in the Twentieth Century. Cambridge: Cambridge University Press, 1995.

Davidson, Allan K. and Peter J. Lineham. Transplanted Christianity: Documents Illustrating Aspects of New Zealand Church History. $3^{\text {rd }}$ ed. Palmerston North: Department of History, Massey University, 1995.

D'Cruze, Shani. Crimes of Outrage: Sex, Violence and Victorian Working Women. DeKalb: Northern Illinois University Press, 1998.

- ed. Everyday Violence in Britain, 1850-1950. Gender and Class. Harlow: Longman, 2000.

Delap, Lucy, Ben Griffin and Abigail Wills, eds. The Politics of Domestic Authority in Britain since 1800. Houndmills: Palgrave Macmillan, 2009.

D'Emilio, John and Estelle B. Freedman. Intimate Matters: A History of Sexuality in America. New York: Harper \& Row, 1988. 
Diamond, Paul. Makereti. Taking Maori to the World. Auckland: Random House, 2007.

DiFonzo, J. Herbie. Beneath the Fault Line - The Popular and Legal Culture of Divorce in Twentieth-Century America. Charlottesville: University Press of Virginia, 1997.

Doggett, Maeve E. Marriage, Wife-Beating and the Law in Victorian England. London: Weidenfeld \& Nicolson, 1992.

Eldred-Grigg, Stevan. Pleasures of the Flesh: Sex and Drugs in Colonial New Zealand, 1840-1915. Wellington: Reed, 1984.

Else, Anne. A Question of Adoption. Closed Stranger Adoption in New Zealand 19441974. Wellington: Bridget Williams Books, 1991.

,ed. Women Together: A History of Women's Organisations in New Zealand. Ngā Rōpu Wahine o te Motu. Wellington: Historical Branch \& Daphne Brassell, 1993.

Fairburn, Miles and Erik Olssen, eds. Class, Gender and the Vote. Historical Perspectives from New Zealand. Otago: University of Otago Press, 2005.

Finlay, Henry. To Have But Not To Hold. A History of Attitudes to Marriage and Divorce in Australia 1858-1975. Sydney: Federation Press, 2005.

Fisher, Kate. Birth Control, Sex, and Marriage in Britain 1918-1960. Oxford: Oxford University Press, 2006.

Frame, Alex. Salmond: Southern Jurist. Wellington: Victoria University Press, 1995.

Frost, Ginger S. Living in Sin. Cohabiting as Husband and Wife in Nineteenth-Century England. Manchester: Manchester University Press, 2008.

Fyfe, Judith and Gaylene Preston, eds. War Stories Our Mothers Never Told Us. Auckland: Penguin, 1995.

Garrigan, Kristine Ottesen, ed. Victorian Scandals. Representations of Gender and Class. Athens: Ohio University Press, 1992.

Gatfield, Gill. Without Prejudice: Women in the Law. Wellington: Brookers, 1996.

Gillis, John R. For Better, For Worse: British Marriages, 1600 to the Present. New York: Oxford University Press, 1985.

Gilding, Michael. The Making and Breaking of the Australian Family. Sydney: Allen \& Unwin, 1991.

Giles, Judy. The Parlour and the Suburb: Domestic Identities, Class, Femininity and Modernity. Oxford: Berg, 2004. 
Glamuzina, Julie and Alison J. Laurie. Parker \& Hulme. A Lesbian View. Auckland: New Women's Press, 1991.

Golder, Hilary. Divorce in New South Wales. Kensington: New South Wales University Press, 1985.

Goodman, Philomena. Women, Sexuality and War. Houndmills: Palgrave Macmillan, 2002.

Gordon, Linda. Heroes of Their Own Lives: The Politics and History of Family Violence, Boston 1880-1960. New York: Viking Press, 1988.

Graham, Peter. Vile Crimes. The Timaru Poisonings. Christchurch: Canterbury University Press, 2007.

Grayzel, Susan. Women and the First World War. London: Pearson, 2002.

- Women's Identities at War: Gender, Motherhood, and Politics in Britain and France During the First World War. Chapel Hill: University of North Carolina Press, 1999.

Grimshaw, Patricia. Women's Suffrage in New Zealand. Auckland: Auckland University Press/Oxford University Press, 1987 ed.

Grimshaw, Patricia, Marilyn Lake, Ann McGrath and Marian Quartly. Creating a Nation, 1788-1990. Ringwood: Penguin, 1994.

Hall, Ruth, ed. Dear Dr. Stopes. Sex in the 1920s. London: André Deutsch, 1978.

Hammerton, A. James. Cruelty and Companionship: Conflict in Nineteenth Century Married Life. London: Routledge, 1992.

Hartog, Hendrik. Man and Wife in America: A History. Cambridge, Mass: Harvard University Press, 2000.

Higonnet, Margaret Randolph, Jane Jenson, Sonya Michel and Margaret Collins Weitz. Behind the Lines: Gender and the Two World Wars. New Haven: Yale University Press, 1987.

Holcombe, Lee. Wives and Property. Reform of the Married Women's Property Law in Nineteenth-Century England. Oxford: Martin Robertson, 1983.

Hunt, Sam, ed. James K. Baxter, Poems. Auckland: Auckland University Press, 2009.

Iacovetta, Franca and Wendy Mitchinson, eds. On the Case: Explorations in Social History. Toronto: University of Toronto Press, 1998.

Igra, Anna R. Wives Without Husbands. Marriage, Desertion, \& Welfare in New York, 1900-1935. Chapel Hill: University of North Carolina Press, 2007. 
Ip, Manying. Dragons on the Long White Cloud. The Making of Chinese New Zealanders. North Shore City: Tadem Press, 1996.

Irvine, Janice M. Talk About Sex. The Battles over Sex Education in the United States. Berkeley: University of California Press, 2002.

Keshen, Jeffrey A. Saints, Sinners, and Soldiers. Canada's Second World War. Vancouver: UBC Press, 2004.

King, Michael. Whina. A Biography of Whina Cooper. Auckland: Penguin, 1991 ed.

Leckie, Barbara. Culture and Adultery. The Novel, the Newspaper and the Law, 18561914. Philadelphia: University of Pennsylvania Press, 1999.

Leneman, Leah. Alienated Affections: The Scottish Experience of Divorce, 1684-1830. Edinburgh: Edinburgh University Press, 1998.

Levine, Philippa. Prostitution, Race \& Politics. Policing Venereal Disease in the British Empire. New York: Routledge, 2003.

Lewis, Jane, David Clark and David H. J. Morgan, eds. 'Whom God Hath Joined Together': The Work of Marriage Guidance. London and New York: Tavistock/Routledge, 1992.

Macdonald, Charlotte, ed. The Vote, the Pill and the Demon Drink: A History of Feminist Writing in New Zealand, 1869-1993. Wellington: Bridget Williams Books, 1993.

Macdonald, Charlotte, Merimeri Penfold and Bridget Williams, eds. The Book of New Zealand Women. Ko Kui Ma Te Kaupapa. Wellington: Bridget Williams Books, 1991.

Margarey, Susan. Passions of the First Wave Feminists. Sydney: University of New South Wales Press, 2001.

Marwick, Arthur. The Deluge. British Society and the First World War. London: Macmillan, 1965.

Mason, Mary Ann. From Father's Property to Children's Rights: A History of Child Custody. New York: Columbia University Press, 1994.

Matthews, Jill Julius. Good and Mad Women: The Historical Construction of Femininity in Twentieth Century Australia. Sydney: Allen \& Unwin, 1984.

May, Elaine Tyler. Great Expectations: Marriage and Divorce in Post-Victorian America. Chicago: University of Chicago Press, 1980.

May, Helen. Minding Children, Managing Men - Conflict and Compromise in the Lives of Postwar Pakeha Women. Wellington: Bridget Williams Books, 1992.

McClure, Margaret. A Civilised Community: A History of Social Security in New Zealand 1898-1998. Auckland: Auckland University Press, 1998. 
Mein Smith, Philippa. A Concise History of New Zealand. Melbourne: Cambridge University Press, 2005.

Millen, Julia. The Story of Bell Gully Buddle Weir, 1840-1990. Wellington: Bell Gully, 1990.

Montgomerie, Deborah. Love in the Time of War. Letter Writing in the Second World War. Auckland: Auckland University Press, 2005.

. The Women's War: New Zealand Women 1939-1945. Auckland: Auckland University Press, 2001.

Nicholls, Roberta. The Women's Parliament. The National Council of the Women of New Zealand 1896-1920. Wellington: Victoria University Press, 1996.

Nolan, Melanie. Breadwinning. New Zealand Women and the State. Christchurch: Canterbury University Press, 2000.

- Kin: A Collective Biography of a New Zealand Working-Class Family. Christchurch: Canterbury University Press, 2005.

November, Janet. In the Footsteps of Ethel Benjamin. New Zealand's First Woman Lawyer. Wellington: Victoria University Press, 2009.

Olssen, Erik and Maureen Hickey. Class and Occupation. The New Zealand Reality. Dunedin: University of Otago Press, 2005.

Page, Dorothy. The National Council of Women. A Centennial History. Auckland: Auckland University Press with Bridget Williams Books, 1996.

Peterson del Mar, David. What Trouble I Have Seen. A History of Violence Against Wives. Cambridge, Mass.: Harvard University Press, 1996.

Phillips, Jock. Royal Summer. The Visit of Queen Elizabeth II and Prince Philip to New Zealand 1953-54. Wellington: Daphne Brassell, 1993.

Phillips, Jock with Ellen Ellis. Brief Encounter. American Forces and the New Zealand People 1942-1945. Wellington: Historical Branch, 1992.

Phillips, Jock and Terry Hearn. Settlers. New Zealand Immigrants from England, Ireland \& Scotland. 1800-1945. Auckland: Auckland University Press, 2008.

Phillips, Roderick. Divorce in New Zealand: A Social History. Auckland: Oxford University Press, 1981.

. Putting Asunder: A Histor
Cambridge University Press, 1988. 
Pool, Ian, Arunachalam Dharmalingam and Janet Sceats. The New Zealand Family from 1840. A Demographic History. Auckland: Auckland University Press, 2007.

Porter, Frances, Charlotte Macdonald with Tui McDonald, eds. 'My Hand Will Write What My Heart Dictates'. The Unsettled Lives of Women in Nineteenth-Century New Zealand as Revealed to Sisters, Family and Friends. Auckland: Auckland University Press/Bridget Williams Books, 1996.

Reynolds, David. Rich Relations. The American Occupation of Britain, 1942-1945. London: HarperCollins, 1995.

Rice, Geoffrey, ed. The Oxford History of New Zealand, $2^{\text {nd }}$ ed. Auckland: Oxford University Press, 1992.

Riley, Glenda. Divorce: An American Tradition. Lincoln, Neb: University of Nebraska Press, 1991.

Robson, John L., ed. New Zealand; the Development of its Laws and Constitution. $2^{\text {nd }}$ ed. London: Stevens, 1967.

Sangster, Joan. Regulating Girls and Women. Sexuality, Family, and the Law in Ontario, 1920-1960. Toronto: Oxford University Press, 2001.

Shanley, Mary L. Feminism, Marriage and the Law in Victorian England, 1850-1895. Princeton: Princeton University Press, 1989.

Simmons, Christina. Making Marriage Modern. Women's Sexuality from the Progressive Era to World War II. New York: Oxford University Press, 2009.

Sinclair, Keith, ed. The Oxford Illustrated History of New Zealand, $2^{\text {nd }}$ ed. Auckland: Oxford University Press, 1996.

Smyth, Helen. Rocking the Cradle. Contraception, Sex and Politics in New Zealand. Wellington: Steele and Roberts, 2000.

Snell, James G. In the Shadow of the Law: Divorce in Canada, 1900-1939. Toronto: University of Toronto Press, 1991.

Spiller, Peter. The Chapman Legal Family. Wellington: Victoria University Press, 1992.

Spiller, Peter, Jeremy Finn and Richard Boast. A New Zealand Legal History. Wellington: Brooker's, 1995.

Stanley, Amy Dru. From Bondage to Contract. Wage Labor, Marriage, and the Market in the Age of Slave Emancipation. Cambridge: Cambridge University Press, 1998.

Stetson, Dorothy M. A Woman's Issue. The Politics of Family Law Reform in England. Westport, Conn.: Greenwood Press, 1982. 
Stone, Lawrence. Road to Divorce: England 1830-1987. Oxford: Oxford University Press, 1990.

Stone, R.C.J. The Making of Russell McVeagh: The First 125 years of the Practice of Russell McVeagh McKenzie Bartleet and Co. 1863-1988. Auckland: Auckland University Press, 1991.

Taylor, Nancy M. The New Zealand People at War: The Home Front. Wellington: Historical Publications Branch, 1986.

Tennant, Margaret. The Fabric of Welfare. Voluntary Organisations, Government and Welfare in New Zealand, 1840-2005. Wellington: Bridget Williams Books, 2007.

- Paupers and Providers: Charitable Aid in New Zealand. Wellington: Allen \& Unwin, 1989.

Tolerton, Jane. Ettie: A Life of Ettie Rout. Auckland: Penguin, 1992.

Toynbee, Claire. Her Work and His. Family, Kin and Community in New Zealand 19001930. Wellington: Victoria University Press, 1995.

Van Grondelle, Carole. Angel of the ANZACS: The Life of Nola Luxford. Wellington: Victoria University Press, 2000.

Wanhalla, Angela. In/Visible Sight: The Mixed-Descent Families of Southern New Zealand. Wellington: Bridget Williams Books, 2009.

Weeks, Jeffrey. Sex, Politics and Society: The Regulation of Sexuality Since 1800. Longman, 1989.

Wilson, J.O. New Zealand Parliamentary Record 1840-1984. Wellington: V.R. Ward \& Government Printer, 1985.

Yska, Redmer. All Shook Up. The Flash Bodgie and the Rise of the New Zealand Teenager in the Fifties. Auckland: Penguin, 1993.

—. Truth. The Rise and Fall of the People's Paper. Nelson: Craig Potton, 2010.

VII. Articles and Chapters

Aitken, Jo. "“The Horrors of Matrimony Among the Masses." Feminist Representations of Wife Beating in England and Australia, 1870-1914'. Journal of Women's History 19, no.4 (2007): 107-31.

- 'Wives and Mothers First: The New Zealand Teachers' Marriage Bar and the Ideology of Domesticity, 1920-1940'. Women's Studies Journal 12, no.1 (1996): 83-98.

Anderson, Olive. 'Emigration and Marriage Break-Up in Mid-Victorian England'. The Economic History Review 50, no.1 (1997): 104-9. 
Anderson, William and Derek W. Little. 'All's Fair: War and Other Causes of Divorce from a Beckerian Perspective'. American Journal of Economics and Sociology 58, no. 4 (1999): 901-22.

Atherton, Rosalind. 'New Zealand's Testators' Family Maintenance Act of 1900 - the Stouts, the Women's Movement and Political Compromise'. Otago Law Review, no.7 (1990): 202-21.

Ayers, Pat and Jan Lambertz. 'Marriage Relations, Money, and Domestic Violence in Working-Class Liverpool, 1919-1939'. In Labour and Love: Women's Experience of Home and Family, 1850-1940, edited by Jane Lewis, 194-219. New York: Basil Blackwell, 1986.

Bailey, Beth L. 'Scientific Truth....and Love: The Marriage Education Movement in the United States'. Journal of Social History 20, no.4 (1987): 711-32.

Basch, Norma. 'Invisible Women: The Legal Fiction of Marital Unity in NineteenthCentury America'. Feminist Studies 5, no.2 (1979): 346-66.

Bauer, Carol and Lawrence Ritt. "AA Husband is a Beating Animal". Frances Power Cobbe Confronts the Wife-Abuse Problem in Victorian England'. International Journal of Women's Studies 6, no.2 (1983): 99-118.

- 'Wife-Abuse, Late-Victorian English Feminists, and the Legacy of Frances Power Cobbe'. International Journal of Women's Studies 6, no.3 (1983): 195-207.

Bourke, Joanna. 'Sexual Violence, Marital Guidance and Victorian Bodies: An Aesthesiology'. Victorian Studies 50, no.3 (2008): 419-36.

Bradbury, Bettina. 'Colonial Comparisons: Rethinking Marriage, Civilisation and Nation in Nineteenth-Century White Settler Societies'. In Rediscovering the British World, edited by Phillip Buckner and R. Douglas Francis, 135-57. Calgary: University of Calgary Press, 2005.

—. 'From Civil Death to Separate Property: Changes in the Legal Rights of Married Women in Nineteenth Century New Zealand'. New Zealand Journal of History, 29, no.1 (1995): 40-66.

-. 'Social, Economic, and Cultural Origins of Contemporary Families'. In Families: Changing Trends in Canada, $4^{\text {th }}$ ed., edited by Maureen Baker, 69-96. Toronto: McGraw-Hill Ryerson, 2001.

Brickell, Chris. 'Court Records and the History of Male Homosexuality'. Archifacts (2008): 25-44.

- 'Same-Sex Desire and the Asylum: A Colonial Experience'. New Zealand Journal of History 39, no.2 (2005): 158-78.

- 'Sexuality, Morality and Society'. In The New Oxford History of New Zealand, edited by Giselle Byrnes, 465-86. Melbourne: Oxford University Press, 2009. 
Brookes, Barbara. 'A Weakness for Strong Subjects: The Women's Movement and Sexuality'. New Zealand Journal of History 27, no.2 (1993): 140-56.

_. 'Gender, Work and Fears of a "Hybrid Race" in 1920s New Zealand'. Gender \& History 19, no.3 (2007): 501-18.

- 'Housewives' Depression. The Debate over Abortion and Birth Control in the 1930s'. New Zealand Journal of History 15, no.2 (1981): 115-34.

- 'Marriage: The Gendered Contract'. In Sites of Gender. Women, Men and Modernity in Southern Dunedin, 1890-1939, edited by Barbara Brookes, Annabel Cooper and Robin Law, 348-55. Auckland: Auckland University Press, 2003.

- 'Women and Madness: A Case-study of the Seacliff Asylum, 1890-1920'. In Women in History 2, edited by Barbara Brookes, Charlotte Macdonald and Margaret Tennant, 129-47. Wellington: Bridget Williams Books, 1992.

Brookes, Barbara, Erik Olssen and Emma Beer. 'Spare Time? Leisure, Gender and Modernity'. In Sites of Gender. Women, Men \& Modernity in Southern Dunedin, 18901939, edited by Barbara Brookes, Annabel Cooper and Robin Law, 151-89. Auckland: Auckland University Press, 2003.

Brooking, Tom. 'Economic Transformation'. In The Oxford History of New Zealand, $2^{\text {nd }}$ ed., edited by Geoffrey Rice, 230-53. Auckland: Oxford University Press, 1992.

Brownlie, Robin Jarvis. 'Intimate Surveillance, Colonization and the Regulation of Aboriginal Women's Sexuality'. In Contact Zones: Aboriginal and Settle Women in Canada's Colonial Past, edited by Katie Pickles and Myra Rutherdale, 160-78. Vancouver: UBC Press, 2005.

Caldwell, Katherine L. 'Not Ozzie and Harriet: Postwar Divorce and the American Liberal Welfare State'. Law \& Social Inquiry 23, no.1 (1998): 1-53.

Call, Vaughn R. A. and Jay D. Teachman. 'Life-Course Timing and Sequencing of Marriage and Military Service and Their Effects on Marital Stability'. Journal of Marriage and Family 58, no.1 (1996): 219-26.

Chapman, Robert. 'From Labour to National'. In The Oxford History of New Zealand, $2^{\text {nd }}$ ed., edited by Geoffrey Rice, 351-84. Auckland: Oxford University Press, 1992.

Christoffel, Paul. 'Prohibition and the Myth of 1919'. New Zealand Journal of History 42, no.2 (2008): 154-175.

Clark, Anna. 'Humanity or Justice? Wifebeating and the Law in the Eighteenth and Nineteenth Centuries'. In Regulating Womanhood. Historical Essays on Marriage, Motherhood and Sexuality, edited by Carol Smart, 187-206. London: Routledge, 1992.

- 'Twilight Moments'. Journal of the History of Sexuality 14, nos.1\&2 (2005): 139-60. 
Cook, Helen. 'The Art of Marriage as a Career for the 1950s'. NZ Women's Studies Journal 2, no.1 (1985): 50-67.

Cook, Hera. 'Demography'. In The Modern History of Sexuality, edited by H.G. Cocks and Matt Houlbrook, 19-40. Houndmills: Palgrave Macmillan, 2006.

- 'The English Sexual Revolution: Technology and Social Change'. History Workshop Journal, no. 59 (2005): 109-28.

- 'Sexuality and Contraception in Modern England: Doing the History of Reproductive Sexuality'. Journal of Social History 40, no.4 (2007): 915-32.

- 'Unseemly and Unwomanly Behaviour: Comparing Women's Control of their Fertility in Australia and England from 1890 to 1970'. Journal of Population Research 17, no.2 (2000): 125-41.

Cook, Matt. 'Law'. In The Modern History of Sexuality, edited by H.G. Cocks and Matt Houlbrook, 64-86. Houndmills: Palgrave Macmillan, 2006.

Cooper, Annabel. 'Poor Men in the Land of Promises. Settler Masculinity and the Male Breadwinner Economy in Late Nineteenth-Century New Zealand'. Australian Historical Studies 39, no.2 (2008): 245-61.

Daley, Caroline. 'Modernity, Consumption and Leisure'. In The New Oxford History of New Zealand, edited by Giselle Byrnes, 423-45. Melbourne: Oxford University Press, 2009.

—. 'Puritans and Pleasure Seekers'. In Sexuality Down Under. Social and Historical Perspectives, edited by Allison Kirkman and Pat Moloney, 47-78. Dunedin: University of Otago Press, 2005.

Dalley, Bronwyn. 'Creeping in Sideways: Reading Sexuality in the Archives'. Archifacts (2001): 35-41.

- 'Criminal Conversations: Infanticide, Gender and Sexuality in NineteenthCentury New Zealand'. In The Gendered Kiwi, edited by Caroline Daley and Deborah Montgomerie, 63-85. Auckland: Auckland University Press, 1999.

- "Fresh Attractions": White Slavery and Feminism in New Zealand, 18851918'. Women's History Review 9, no.3 (2000): 585-606.

. 'The Golden Weather, 1949-1965'. In Frontier of Dreams. The Story of New Zealand, edited by Bronwyn Dalley and Gavin McLean, 306-35. Auckland: Hodder Moa, 2005.

- 'Lolly Shops "of the red-light kind" and "soldiers of the King": Suppressing One-Woman Brothels in New Zealand, 1908-1916'. New Zealand Journal of History 30, no.1 (1996): 3-23. 
Dalziel, Raewyn. "“Making Us One": Courtship and Marriage in Colonial New Zealand'. The Turnbull Library Record 19, no.1 (1986): 7-26.

Darian-Smith, Kate. 'Remembering Romance: Memory, Gender and World War II'. In Gender and War. Australians at War in the Twentieth Century, edited by Joy Damousi and Marilyn Lake, 117-29. Cambridge: Cambridge University Press, 1995.

D'Cruze, Shani. 'Intimacy, Professionalism and Domestic Homicide in Interwar Britain: the case of Buck Ruxton'. Women's History Review 16, no.5 (2007): 701-22.

- 'Sex, Violence and Local Courts. Working-Class Respectability in a MidNineteenth-Century Lancashire Town'. British Journal of Criminology 39, no.1 (1999): 39-55.

Dunstall, Graeme. 'The Social Pattern'. In The Oxford History of New Zealand, $2^{\text {nd }}$ ed., edited by Geoffrey Rice, 451-81. Auckland: Oxford University Press, 1992.

Fairburn, Miles. 'The Farmers Take Over (1912-1930)'. In The Oxford Illustrated History of New Zealand, $2^{\text {nd }}$ ed., edited by Keith Sinclair, 185-209. Auckland: Oxford University Press, 1996.

- 'Why Did the New Zealand Labour Party Fail to Win Office until 1935?' Political Science 37, no.2 (1985): 101-24.

Fairburn, Miles and S.J. Haslett. 'Stability and Egalitarianism: New Zealand, 1911-1951'. In Class, Gender and the Vote. Historical Perspectives from New Zealand, edited by Miles Fairburn and Erik Olssen, 15-33. Otago: University of Otago Press, 2005.

Featherstone, Lisa. 'Sexy Mamas? Women, Sexuality and Reproduction in Australia in the 1940s'. Australian Historical Studies 36, no.126 (2005): 234-52.

Finch, Janet and Penny Summerfield. 'Social Reconstruction and the Emergence of Companionate Marriage, 1945-59'. In Marriage, Domestic Life and Social Change. Writings for Jacqueline Burgoyne (1944-88), edited by David Clark, 7-32. London and New York: Routledge, 1991.

Finch, Lyn. 'Consuming Passions: Romance and Consumerism during World War II'. In Gender and War. Australians at War in the Twentieth Century, edited by Joy Damousi and Marilyn Lake, 105-16. Cambridge: Cambridge University Press, 1995.

Finlay, Henry. 'Lawmaking in the Shadow of the Empire: Divorce in Colonial Australia'. Journal of Family History 24, no.1 (1999):74-109.

Fleming, Philip. 'Fighting the "Red Plague": Observations on the Response to Venereal Disease in New Zealand 1910-1945'. New Zealand Journal of History 22, no.1 (1988): 56-64.

Fokkema, Tineke and Aart C Liefbroer. 'Employment and Divorce Among Dutch Women Born Between 1903 and 1937'. History of the Family 9, no.4 (2004): 425-42. 
Fortune, Gabrielle. “"Mr Jones' Wives": War Brides, Marriage, Immigration and Identity Formation'. Women's History Review 15, no.4 (2006): 587-99.

Geppert, Alexander C.T. 'Divine Sex, Happy Marriage, Regenerated Nation: Marie Stopes's Marital Manual Married Love and the Making of a Best-Seller, 1918-1955'. Journal of the History of Sexuality 8, no.3 (1998): 389-433.

Gillis, A.R. 'So Long as They Both Shall Live: Marital Dissolution and the Decline of Domestic Homicide in France, 1852-1909'. The American Journal of Sociology 101, no.5 (1996): 1273-1305.

Gilson, Miriam. 'The Changing New Zealand Family: A Demographic Analysis'. In Marriage and the Family in New Zealand, edited by S. Houston, 41-65. Wellington: Sweet and Maxwell, 1970.

Gimbel, Cynthia and Alan Booth. 'Why Does Military Combat Experience Adversely Affect Marital Relations?' Journal of Marriage and the Family 56, no.3 (1994): 691-703.

Gleason, Mona. 'Psychology and the Construction of the 'Normal' Family in Postwar Canada, 1945-60’. The Canadian Historical Review 78, no.3 (1997): 442-77.

Goodman, Phil. “Patriotic Femininity": Women's Morals and Men's Morale During the Second World War'. Gender \& History 10, no.2 (1998): 278-93.

Griswold, Erwin. 'Divorce Jurisdiction and Recognition of Divorce Decrees: A Comparative Study'. Harvard Law Review 65, no.2 (1951): 193-233.

Griswold, Robert L. 'Divorce and the Legal Redefinition of Victorian Manhood'. In Meanings for Manhood. Constructions of Masculinity in Victorian America, edited by Mark C. Carnes and Clyde Griffen, 96-110. Chicago: The University of Chicago Press, 1990.

'.The Evolution of the Doctrine of Mental Cruelty in Victorian American Divorce, 1790-1900'. Journal of Social History 20, no.1 (1986): 127-48.

. 'Law, Sex, Cruelty, and Divorce in Victorian America, 1840-1900'. American Quarterly 38, no.5 (1986): 721-45.

—. 'Sexual Cruelty and the Case for Divorce in Victorian America'. Signs 11, no.3 (1986): 529-41.

Grossberg, Michael. 'Who Gets the Child? Custody, Guardianship, and the Rise of a Judicial Patriarchy in Nineteenth-Century America'. Feminist Studies 9, no.2 (1983): 235-60.

Guthrie, Charles J. 'The History of Divorce in Scotland'. Scottish Historical Review 8 (1910): 39-52. 
Haag, Pamela. "The "Ill-Use of a Wife": Patterns of Working-Class Violence in Domestic and Public New York City, 1860-1880'. Journal of Social History 25, no.3 (1992): 44777.

Hamer, David. 'Centralization and Nationalism (1891-1912)'. In The Oxford Illustrated History of New Zealand, $2^{\text {nd }}$ ed., edited by Keith Sinclair, 125-52. Auckland: Oxford University Press, 1996.

Hammerton, A. James. 'Victorian Marriage and the Law of Matrimonial Cruelty'. Victorian Studies 33, no.2 (1990): 269-92.

Harris, Alana. “"A paradise on earth, a foretaste of heaven': English Catholic Understandings of Domesticity and Marriage, 1945-1965'. In The Politics of Domestic Authority in Britain since 1800, edited by Lucy Delap, Ben Griffin and Abigail Wills, 155-81. Houndmills: Palgrave Macmillan, 2009.

Hilliard, David. 'Church, Family and Sexuality in Australia in the 1950s'. Australian Historical Studies 27, no.109 (1997): 133-46.

Holden, A.C. 'Divorce in the Commonwealth: A Comparative Study'. The International and Comparative Law Quarterly 20, no.1 (1971): 58-74.

Holden, Katherine. "Nature Takes No Notice of Morality": Singleness and Married Love in Interwar Britain'. Women's History Review 11, no.3 (2002): 481-503.

Holloway, Judith. "Unfortunate Folk." A Study of the Social Context of Committal to Seacliff, 1928-1937'. In 'Unfortunate Folk'. Essays on Mental Health Treatment 18631992, edited by Barbara Brookes and Jane Thomson, 153-67. Dunedin: University of Otago Press, 2001.

Holmes, Ann Sumner. 'The Double Standard in the English Divorce Laws, 1857-1923'. Law \& Social Inquiry 20, no.2 (1995): 601-20.

- "Fallen Mothers". Maternal Adultery and Child Custody in England, 18861925'. In Maternal Instincts. Visions of Motherhood and Sexuality in Britain, 1875-1925, edited by Claudia Nelson and Ann Sumner Holmes, 37-57. Houndsmills, UK: Macmillan, 1997.

Holmes, Katie. "Filing the Empty Cradles": Sexuality, Maternity, and the Effects of Depression and War on Gender Relations in Australia'. In Through Depression and War: The United States and Australia, edited by Roger J. Bell and Peter Edward, 51-61. Sydney: Australian-American Fulbright Association, 2002.

-. "Spinsters Indispensable": Feminists, Single Women and the Critique of Marriage, 1890-1920'. Australian Historical Studies 29, no.110 (1998): 68-90.

Holtzman, Ellen M. 'The Pursuit of Married Love: Women's Attitudes Toward Sexuality and Marriage in Great Britain, 1918-1939'. Journal of Social History 16, no.2 (1982): 3951 . 
Humphreys, Anne. 'Coming Apart: The British Newspaper Press and the Divorce Court'. In Defining Centres: Nineteenth-Century Media and the Construction of Identities, edited by Laurel Brake, William Bell and David Finkelstein, 220-31. Houndmills: Palgrave Macmillan, 2000.

Jackson, Hugh. 'Churchgoing in Nineteenth-Century New Zealand'. New Zealand Journal of History 17, no.1 (1983):43-59.

James, Colin. 'A History of Cruelty in Australian Divorce'. ANZLH E-Journal (2006): 130 .

'Winners and Losers: The Father Factor in Australian Child Custody Law in the $20^{\text {th }}$ Century'. Legal History 10 (2006): 207-38.

James, Margaret. 'Double Standards in Divorce. Victoria 1890-1960'. In In Pursuit of Justice: Australian Women and the Law 1768-1979, edited by Judy Mackinalty \& Heather Radi, 202-11. Sydney: Hale \& Iremonger, 1979.

Kampf, Antje. 'Controlling Male Sexuality: Combating Venereal Disease in the New Zealand Military during Two World Wars'. Journal of the History of Sexuality 17, no.2 (2008): 235-58.

Klein, Joanne. 'Irregular Marriages: Unorthodox Working-Class Domestic Life in Liverpool, Birmingham, and Manchester, 1900-1939'. Journal of Family History 30, no.2 (2005): 210-29.

Labrum, Bronwyn. 'Looking Beyond the Asylum. Gender and the Process of Committal in Auckland, 1870-1910'. New Zealand Journal of History 26, no.2 (1992): 125- 44.

—. 'Persistent Needs and Expanding Desires: Pākehā Families and State Welfare in the Years of Prosperity'. In Fragments. New Zealand Social \& Cultural History, edited by Bronwyn Dalley and Bronwyn Labrum, 188-210. Auckland: Auckland University Press, 2000.

Lake, Marilyn. 'The Desire for a Yank: Sexual Relations between Australian Women and American Servicemen During World War II'. Journal of the History of Sexuality 2, no.4 (1992): 621-33.

—. 'Female desires: The meaning of World War II'. Australian Historical Studies 24, no. 95 (1990): 267-84.

'Historical Homes'. Australian Historical Studies 24, no.96 (1991): 46-54.

- 'Mission Impossible: How Men Gave Birth to the Australian Nation Nationalism, Gender and Other Seminal Acts'. Gender \& History 4, no.3 (1992): 305-22.

Langhamer, Claire. 'Adultery in Post-war England'. History Workshop Journal, 62 (2006): 87-115. 
. 'Love and Courtship in Mid-Twentieth-Century England'. The Historical Journal 50, no.1 (2007): 173-96.

- 'The Meanings of Home in Postwar Britain'. Journal of Contemporary History 40, no.2 (2005): 341-62.

Lee, Jenny Bol Jun. 'Eating Pork Bones and Puha with Chopsticks: Maori-Chinese Constructions'. In Unfolding History, Evolving Identity. The Chinese in New Zealand, edited by Manying Ip, 94-112. Auckland: Auckland University Press, 2003.

Leneman, Leah. 'English Marriages and Scottish Divorces in the Early Nineteenth Century'. The Journal of Legal History 17, no.3 (1996): 225-43.

Lineham, Peter J. 'The Religious Face of Patriotism'. In Kia Kaha. New Zealand in the Second World War, edited by John Crawford, 199-220. Auckland: Oxford University Press, 2000.

Little, Margaret Hillyard. 'Ontario Mothers' Allowance Case Files as a Site of Contestation'. In On the Case: Explorations in Social History, edited by Franca Iacovetta and Wendy Mitchinson, 227-41. Toronto: University of Toronto Press, 1998.

Lloyd, Jacky. 'Marital Breakdown'. In Families in New Zealand Society, edited by Peggy Koopman-Boyden, 138-53. Wellington: Methuen, 1978.

Macdonald, Charlotte. 'Crime and Punishment in New Zealand, 1840-1913: a Gendered History'. New Zealand Journal of History 23, no.1 (1989): 5-21.

—. 'The "Social Evil". Prostitution and the Passage of the Contagious Diseases Act (1869)'. In Women in History, Essays on European Women in New Zealand, edited by Barbara Brookes, Charlotte Macdonald and Margaret Tennant, 13-33. Wellington: Allen \& Unwin/ Port Nicholson Press, 1986.

_. 'Too Many Men and Too Few Women: Gender's "Fatal Impact" in NineteenthCentury Colonies'. In The Gendered Kiwi, edited by Caroline Daley and Deborah Montgomerie, 17-35. Auckland: Auckland University Press, 1999.

- 'Ways of Belonging: Sporting Spaces in New Zealand History'. In The New Oxford History of New Zealand, edited by Giselle Byrnes, 269-96. Melbourne: Oxford University Press, 2009.

May, Elaine Tyler. 'The Pressure to Provide: Class, Consumerism, and Divorce in Urban America, 1880-1920'. Journal of Social History 12, no.2 (1978): 180-93.

McClure, Margaret. “'When a Happy Marriage Turns to Custard”. Women's Stories of Divorce in the 1950s and 1960s'. Oral History in New Zealand, 18 (1996): 1-4.

McCormick, Leanne. “"One Yank and They're Off”: Interaction between U.S. Troops and Northern Irish Women, 1942-1945'. Journal of the History of Sexuality 15, no.2 (2006): 228-57. 
Mein Smith, Philippa. 'Blood, Birth, Babies, Bodies'. Australian Feminist Studies 17, no.39 (2002): 305-23.

Molloy, Maureen. 'Citizenship, Property and Bodies: Discourses on Gender and the InterWar Labour Government in New Zealand'. Gender \& History 4, no.3 (1992): 293-304.

Montgomerie, Deborah. 'GI Joe Down Under: American Infantrymen in New Zealand During World War II'. New Zealand Journal of History 34, no.2 (2000): 262-76.

—. 'The Limitations of War-Time Change - Women War Workers in New Zealand'. New Zealand Journal of History 23, no.1 (1989): 68-86.

—. 'Men's Jobs and Women's Work: The New Zealand Women's Land Service in World War II'. Agricultural History 63, no.3 (1989): 1-13.

_. 'Reassessing Rosie: World War II, New Zealand Women and the Iconography of Femininity'. Gender \& History 8, no.1 (1996): 108-32.

—. 'Sweethearts, Soldiers, Happy Families: Gender and the Second World War'. In The Gendered Kiwi, edited by Caroline Daley and Deborah Montgomerie, 163-90. Auckland: Auckland University Press, 1999.

Morgan, David H.J. 'Marriage and Society: Understanding an Era of Change'. In 'Whom God Hath Joined Together' The Work of Marriage Guidance, edited by Jane Lewis, David Clark and David H.J. Morgan, 6-34. London and New York: Tavistock/Routledge, 1992.

Morris, Grant. “'Salmond's Bench": The New Zealand Supreme Court Judiciary 19201924'. Victoria University of Wellington Law Review, no.38 (2007): 813-30.

Moskowitz, Eva. 'Women's Magazines and a Discourse of Discontent, 1945-1965'. Journal of Women's History 8, no.3 (1996): 66-98.

Murphy, Nigel. "'Māoriland" and "Yellow Peril": Discourses of Māori and Chinese in the Formation of New Zealand's National Identity 1890-1914'. In The Dragon and the Taniwha. Mãori and Chinese in New Zealand, edited by Manying Ip, 56-88. Auckland: Auckland University Press, 2009.

Nadelhaft, Jerome. 'Wife Torture: A Known Phenomenon in Nineteenth-Century America'. Journal of American Culture 10, no.3 (1987): 39-59.

Neuhaus, Jessamyn. 'The Importance of Being Orgasmic: Sexuality, Gender, and Marital Sex Manuals in the United States, 1920-1963'. Journal of the History of Sexuality 9, no.4 (2000): 447-73.

. 'The Way to a Man's Heart: Gender Roles, Domestic Ideology, and Cookbooks in the 1950s'. Journal of Social History 32, no.3 (1999): 529-55. 
Nolan, Melanie. 'Constantly on the Move, But Going Nowhere? Work, Community and Social Mobility'. In The New Oxford History of New Zealand, edited by Giselle Byrnes, 357-87. Melbourne: Oxford University Press, 2009.

- " "Keeping New Zealand Home Fires Burning": Gender, Welfare and the First World War'. In New Zealand's Great War. New Zealand, the Allies and the First World War, edited by John Crawford and Ian McGibbon, 493-515. Auckland: Exisle, 2007.

- " "Politics Swept Under a Domestic Carpet"? Fracturing Domesticity and the Male Breadwinner Wage: Women's Economic Citizenship, 1920s-1940s'. New Zealand Journal of History 27, no.2 (1993): 199-217.

- 'Unstitching the New Zealand State: Its Role in Domesticity and Its Decline'. International Review of Social History 45, no.2 (2000): 251-77.

O'Connor, P.S. 'Sectarian Conflict in New Zealand, 1911-1920'. Political Science 19, no.1 (1967): 3-16.

Olssen, Erik. 'Depression and War (1931-1949)'. In The Oxford Illustrated History of New Zealand, $2^{\text {nd }}$ ed., edited by Keith Sinclair, 211-35. Auckland: Oxford University Press, 1996.

—. "For Better or Worse": Marriage Patterns in Dunedin's Southern Suburbs, 18811938'. In Class, Gender and the Vote: Historical Perspectives from New Zealand, edited by Miles Fairburn and Erik Olssen, 75-100. Dunedin: University of Otago Press, 2005.

'Towards a New Society'. In The Oxford History of New Zealand, $2^{\text {nd }}$ ed., edited by Geoffrey Rice, 254-84. Auckland: Oxford University Press, 1992.

Page, Dorothy. 'Women and Nationality. Feminist Organisations in the Inter-War Period'. In Women in History, Essays on European Women in New Zealand, edited by Barbara Brookes, Charlotte Macdonald and Margaret Tennant, 157-175. Wellington: Allen \& Unwin/ Port Nicholson Press, 1986.

Pavalko, Eliza K. and Glen H. Elder Jr. 'World War II and Divorce: A Life-Course Perspective'. The American Journal of Sociology 95, no.5 (1990): 1213-34.

Pearson, David. 'The "Majority Factor": Shaping Chinese and Māori Minorities'. In The Dragon and the Taniwha. Mãori and Chinese in New Zealand, edited by Manying Ip, 3255. Auckland: Auckland University Press, 2009.

'Marriage and Mobility in Wellington, 1881-1980'. New Zealand Journal of History 22, no.2 (1988): 135-51.

Perry, Peter. 'Marriage-Distance Relationships in North Otago 1875-1914'. New Zealand Geographer 25, no.1 (1969): 36-43.

Phillips, Jim. 'Why Legal History Matters'. Victoria University of Wellington Law Review 41, no.3 (2010): 293-316. 
Phillips, Jock. 'Mummy's Boys: Pakeha Men and Male Culture in New Zealand'. In Women in New Zealand Society, edited by Phillida Bunkle and Beryl Hughes, 217-43. Auckland: George Allen \& Unwin, 1980.

Pickles, Katie. 'Colonisation, Empire and Gender'. In The New Oxford History of New Zealand, edited by Giselle Byrnes, 219-41. Melbourne: Oxford University Press, 2009.

Pleck, Elizabeth. 'Feminist Responses to "Crimes against Women," 1868-1896'. Signs 8, no.3 (1983): 451-70.

Plumridge, Libby. 'The Necessary but not Sufficient Condition: Christchurch Labour and Working-Class Culture'. New Zealand Journal of History 19, no.2 (1985): 130-50.

Reiger, Kerreen. 'The Coming of the Counsellors: The Development of Marriage Guidance in Australia'. Australia and New Zealand Journal of Sociology 23, no.3 (1987): 375-87.

Richardson, C. James. 'Divorce and Remarriage'. In Families. Changing Trends in Canada. $4^{\text {th }}$ ed., edited by Maureen Baker, 206-37.Toronto: McGraw-Hill Ryerson, 2001.

Richardson, Len. 'Parties and Political Change'. In The Oxford History of New Zealand, $2^{\text {nd }}$ ed., edited by Geoffrey Rice, 201-29. Auckland: Oxford University Press, 1992.

Robb, George. 'Marriage and Reproduction'. In The Modern History of Sexuality, edited by H.G. Cocks and Matt Houlbrook, 87-108. Houndmills: Palgrave Macmillan, 2006.

Robertson, Stephen. 'What's Law Got to Do With It? Legal Records and Sexual Histories'. Journal of the History of Sexuality 14, nos.1\&2 (2005): 161-85.

Rose, Sonya O. 'Girls and GIs: Race, Sex, and Diplomacy in Second World War Britain'. The International History Review 19, no.1 (1997): 146-60.

- 'Sex, Citizenship, and the Nation in World War II Britain'. The American Historical Review 103, no.4 (1998): 1147-76.

- 'The "Sex Question" in Anglo-American Relations in the Second World War'. The International History Review 20, no.4 (1998): 884-903.

Rowntree, Griselda and Norman H. Carrier. 'The Resort to Divorce in England and Wales, 1858-1957'. Population Studies 11, no.3 (1958): 188-233.

Ryan, Rebecca M. 'The Sex Right: A Legal History of the Marital Rape Exemption'. Law \& Social Inquiry 20, no.4 (1985): 941-1001.

Saunders, Kay. 'In a Cloud of Lust: Black GIs and Sex in World War II'. In Gender and War. Australians at War in the Twentieth Century, edited by Joy Damousi and Marilyn Lake, 178-90. Cambridge: Cambridge University Press, 1995. 
Savage, Gail. “"A State of Personal Danger”: Domestic Violence in England, 1903-1922'. In Assaulting the Past: Placing Violence in Historical Context, edited by Katherine D. Watson, 269-85. Newcastle: Cambridge Scholars Publishing, 2007.

'Divorce and the Law in England and France Prior to the First World War'. Journal of Social History 21, no.3 (1988): 499-513.

- 'Erotic Stories and Public Decency: Newspaper Reporting of Divorce Proceedings in England'. The Historical Journal 41, no.2 (1998): 511-28.

—. "Intended Only for the Husband": Gender and Class and the Provision for Divorce in England, 1858-1868'. In Victorian Scandals: Representations of Gender and Class, edited by Kristine Ottesen Garrigan, 11-42. Athens: Ohio University Press, 1992.

_. "“...the instrument of an animal function": Marital Rape and Sexual Cruelty in the Divorce Court, 1858-1908'. In The politics of Domestic Authority in Britain Since 1800, edited by Lucy Delap, Ben Griffin and Abigail Wills, 43-57.

—. "The Magistrates are Men:' Working Class Marital Conflict and Appeals from the Magistrates' Court to the Divorce Court After 1895." In Disorder in the Court, edited by George Robb and Nancy Erber, 231-49. New York: New York University Press, 1999.

'The Operation of the 1857 Divorce Act, 1860-1910. A Research Note'. Journal of Social History 16, no.4 (1983): 103-10.

—. "The Wilful Communication of a Loathsome Disease": Marital Conflict and Venereal Disease in Victorian England'. Victorian Studies 34, no.1 (1990): 35-54.

Schrader, Ben. 'Labour at Home. The First Labour Government and the Familial Suburban Ideal'. In At Home in New Zealand. History, Houses, People, edited by Barbara Brookes, 125-39. Wellington: Bridget Williams Books, 2000.

Schwartzberg, Beverly. "Lots of Them Did That": Desertion, Bigamy, and Marital Fluidity in Late-Nineteenth-Century America'. Journal of Social History 37, no.3 (2004): 573-600.

Schwatka, Gladys L. 'Recognition of Foreign Country Divorces: Is Domicile Really Necessary?' California Law Review 40, no.1 (1952): 93-103.

Shammas, Carole. 'Re-Assessing the Married Women's Property Acts'. Journal of Women's History 6, no.1 (1994): 9-30.

Shaw, Louise. 'A Woman's Place?' In At Home in New Zealand. History, Houses, People, edited by Barbara Brookes, 165-80. Wellington: Bridget Williams Books, 2000.

Shum, Lynette. 'Remembering Chinatown: Haining Street of Wellington'. In Unfolding History, Evolving Identity. The Chinese in New Zealand, edited by Manying Ip, 73-93. Auckland: Auckland University Press, 2003. 
Smart, Judith. 'Sex, the State and the "Scarlet Scourge": Gender, Citizenship and Venereal Diseases Regulation in Australia during the Great War'. Women's History Review 7, no.1 (1998): 5-35.

Smith-Rosenberg, Carroll. 'The Female World of Love and Ritual: Relations between Women in Nineteenth-Century America'. Signs 1, no.1 (1975): 1-29.

Stenhouse, John. 'Church, Occupation and Class in Southern Dunedin, 1890-1940'. In Class, Gender and the Vote. Historical Perspectives from New Zealand, edited by Miles Fairburn and Erik Olssen, 15-33. Otago: University of Otago Press, 2005.

'God, the Devil and Gender'. In Sites of Gender. Women, Men \& Modernity in Southern Dunedin, 1890-1939, edited by Barbara Brookes, Annabel Cooper and Robin Law, 151-89. Auckland: Auckland University Press, 2003.

- 'Religion and Society'. In The New Oxford History of New Zealand, edited by Giselle Byrnes, 313-47. Melbourne: Oxford University Press, 2009.

Strange, Carolyn. 'Masculinities, Intimate Femicide and the Death Penalty in Australia, 1890-1920'. British Journal of Criminology 43, no.2 (2003): 310-39.

Stratton, Jon. 'Bodgies and Widgies - Youth Culture in the 1950s'. Journal of Australian Studies 8, no.15 (1984): 10-24.

Strong-Boag. Veronica. 'Home Dreams: Women and the Suburban Experiment in Canada, 1945-60'. The Canadian Historical Review 72, no.4 (1991): 471-504.

Sturma, Michael. 'Loving the Alien; The Underside of Relations Between American Servicemen and Australian Women in Queensland, 1942-1945'. Journal of Australian Studies 13, no.24 (1989): 3-17.

'Public Health and Sexual Morality. Venereal Disease in World War II Australia', in Outrageous! Moral Panics in Australia, edited by Scott Poynting and George Morgan, 197-209. Hobart: University of Tasmania Press, 2007.

Summerfield, Penny. 'Gender and War in the Twentieth Century'. The International History Review 19, no.1 (1997): 2-15.

Summerfield, Penny and Nicole Crockett. "You Weren't Taught that with the Welding": Lessons in Sexuality in the Second World War'. Women's History Review 1, no.3 (1992): 435-54.

Szreter, Simon and Kate Fisher. 'Love and Authority in Mid-Twentieth-Century Marriages: Sharing and Caring'. In The Politics of Domestic Authority in Britain since 1800, edited by Lucy Delap, Ben Griffin and Abigail Wills, 132-54. Houndmills: Palgrave Macmillan, 2009.

Tennant, Margaret. 'The Decay of Home Life? The Home in Early Welfare Discourses'. In At Home in New Zealand. History, Houses, People, edited by Barbara Brookes, 24-40. Wellington: Bridget Williams Books, 2000. 
Thane, Pat. 'Family Life and "Normality" in Postwar British Culture'. In Life after Death. Approaches to a Cultural and Social History of Europe during the 1940s and 1950s, edited by Richard Bessel and Dirk Schumann, 193-210. Cambridge: Cambridge University Press, 2003.

Thomas, Keith. 'The Double Standard'. Journal of the History of Ideas 20, no.2 (1959): 195-216.

Thomson, David. 'Marriage and Family on the Colonial Frontier'. In Disputed Histories. Imagining New Zealand's Pasts, edited by Tony Ballantyne and Brian Moloughney, 11942. Dunedin: University of Otago Press, 2006.

Troughton, Geoffrey. 'Religion, Churches and Childhood in New Zealand, c.1900-1940'. New Zealand Journal of History 40, no.1 (2006): 39-56.

Vogel, Ursula. 'Whose Property? The Double Standard of Adultery in NineteenthCentury Law'. In Regulating Womanhood. Historical Essays on Marriage, Motherhood and Sexuality, edited by Carol Smart, 147-65. London: Routledge, 1992.

Waddams, S.M. 'English Matrimonial Law on the Eve of Reform (1828-57)'. Legal History 21, no.2 (2000): 59-82.

Wanhalla, Angela. 'Family, Community and Gender'. In The New Oxford History of New Zealand, edited by Giselle Byrnes, 447-64. Melbourne: Oxford University Press, 2009.

- 'To "Better the Breed of Men": Women and Eugenics in New Zealand, 19001935'. Women's History Review 16, no.2 (2007): 163-82.

VIII. Theses and Research Essays

Bannister, Carole A. 'Attitudes to Marriage in Selected New Zealand Periodicals, 19601969'. BA(Hons) research essay, University of Otago, 1991.

Brosnahan, D.M. 'A Woman's Place: Changing Attitudes to the Role of Women in Society during World War II in New Zealand'. MA thesis, University of Canterbury, 1987.

Brown, Carol. 'Ethel Benjamin: New Zealand's First Woman Lawyer'. BA(Hons) research essay, University of Otago, 1985.

Buxton, Erica. 'Realigning Dreams. The Marriages of New Zealand Women and American Servicemen during World War Two'. BA(Hons) research essay, University of Otago, 2010.

Burgess, Charlotte. 'Looking to the Heart: Young People, Romance and Courtship in Interwar New Zealand'. MA thesis, University of Auckland, 2007. 
Connell, E. Claire. 'Women in Politics, 1893-1896: A Study of Women's Organisations and Their Interest in Social and Political Reform'. BA(Hons) essay, University of Otago, 1975.

Chivers, Susan L. "“A Man's Home is His Castle": Domestic Violence in Dunedin 18881914'. BA(Hons) research essay, University of Otago, 1988.

Christoffel, Paul. 'Removing Temptation: New Zealand's Alcohol Restrictions, 18812005'. PhD thesis, Victoria University of Wellington, 2006.

Evans, Courtney. "Not Aunt Daisy": Ambivalence in the Representation of Womanhood in Postwar New Zealand'. MA thesis, University of Auckland, 2005.

Fleming, Philip. “"Shadow over New Zealand": The Respondent to Venereal Disease in New Zealand 1910-1945'. PhD thesis, Massey University, 1989.

Fortune, Gabrielle. "“Mr Jones' Wives" World War II Brides of New Zealand Servicemen'. PhD thesis, University of Auckland, 2005.

Gimpel, Tara. 'Marriage, Singleness and Sexuality. An Investigation of the Construction, Representation and Practice of Heterosexuality in 1950s New Zealand'. BA(Hons) research essay, University of Otago, 2009.

Gooder, Claire. 'A History of Sex Education in New Zealand, 1939-1985'. PhD thesis, University of Auckland, 2010.

Green, Jane. 'The Society for the Protection of Women and Children: Dunedin Branch, 1914-1945'. BA(Hons) research essay, University of Otago, 1982.

Jenkins, Justine L. 'Mine, Yours, Ours: An Economic Analysis of the Development of Matrimonial Property and Divorce Law in New Zealand 1880-1980'. MA thesis, University of Auckland, 2001.

Joblin, Richard S. L. 'The Breath of Scandal. New Zealand Truth and Interwar Society, 1918-1939'. MA thesis, University of Canterbury, 1990.

Labrum, Bronwyn. 'Family Needs and Family Desires: Discretionary State Welfare in New Zealand, 1920-1970'. PhD thesis, Victoria University of Wellington, 2000.

- 'Gender and Lunacy. A Study of Women Patients at the Auckland Lunatic Asylum 1870-1910’. MA thesis, Massey University, 1990.

Laws, Diane J. "“Opening the Floodgates": Changes in New Zealand Divorce Legislation 1867-1922'. BA(Hons) research essay, University of Otago, 1980.

Lepp, Annalee E. 'Dis/Membering the Family: Marital Breakdown, Domestic Conflict, and Family Violence in Ontario, 1830-1920'. PhD thesis, Queen's University, 2001.

MacCuish, Fiona J. 'The Society for the Protection of Women and Children, 1893-1916'. BA(Hons) research essay, University of Auckland, 1984. 
Mansell, Wade M. 'The History of the Development of the Grounds for Divorce in New Zealand'. LLM thesis, Victoria University of Wellington, 1970.

Montgomerie, Deborah. 'A Personal Affair Between Me and Hitler? Public Attitudes to Women's Paid Work in New Zealand during World War II'. MA thesis, University of Auckland, 1986.

Page, Dorothy. “"A Married Woman, or a Minor, Lunatic or Idiot”: the Struggle of British Women Against Disability in Nationality, 1914-1933'. PhD thesis, University of Otago, 1984.

Reid, Melissa L. 'The Society for Protection of Women and Children: Dunedin Branch, 1899-1914'. BA(Hons) research essay, University of Otago, 1981.

Sacksen, Lisa. 'The Very Error of the Moon. Dr Theodore Grant Gray and the 1928 Mental Defectives Amendment Act'. BA(Hons) research essay, Victoria University of Wellington, 2005.

Schofield, Simon A. 'A Legal History of Marital Violence in Christchurch 1890-1900'. BA(Hons) research essay, University of Canterbury, 2010.

Simpson, Jane M. R. 'The Churches and the Changing Role of Women in New Zealand Society, 1939-1959'. PhD thesis, University of Otago, 1992.

Stedman, Brenda L. 'The Origins and Development of the Dunedin Marriage Guidance Council, 1948-1970'. BA(Hons) research essay, University of Otago, 1988.

Tulloch, Tracy. 'State Regulations and Sexuality in New Zealand 1880-1925'. PhD thesis, University of Canterbury, 1997.

Wanhalla, Angela C. 'Gender, Race and Colonial Identity: Women and Eugenics in New Zealand, 1918-1939'. MA thesis, University of Canterbury, 2001.

- 'Transgressing Boundaries: A History of the Mixed Descent Families of Maitapapa, Taieri, 1830-1940'. PhD thesis, University of Canterbury, 2004. 